\title{
Kortlægning af potentielle geotermiske reservoirer i Danmark
}

\author{
af \\ Olaf Michelsen, Svend Saxov, Jørgen A. Leth \\ Claus Andersen, Niels Balling, Niels Breiner, Lise Holm, \\ Knud Jensen, Jan I. Kristiansen, Troels Laier, Erik Nygaard, \\ Jens Chr. Olsen, Kurt D. Poulsen, Søren Priisholm, Thomas B. Raade, \\ Torben Rex Sørensen og Jørgen Würtz
}

Red. af Olaf Michelsen

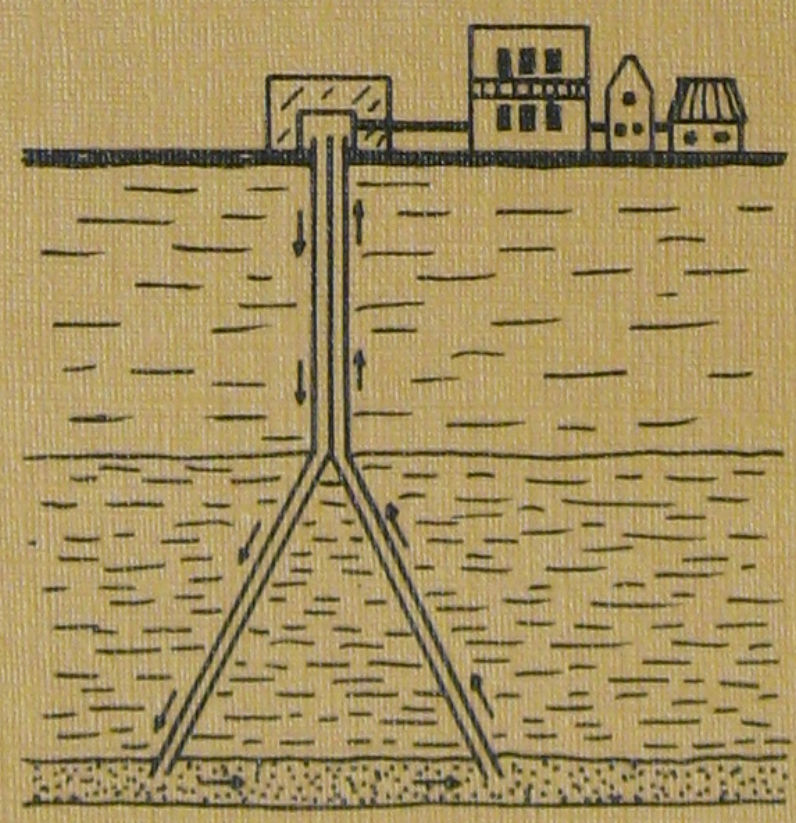

I kommission hos C. A. Reitzels forlag. København 1981 


\section{Kortlægning af potentielle geotermiske reservoirer i Danmark}

af

Olaf Michelsen, Svend Saxov, Jørgen A. Leth, Claus Andersen, Niels Balling, Niels Breiner, Lise Holm, Knud Jensen, Jan I. Kristiansen, Troels Laier, Erik Nygaard, Jens Chr. Olsen, Kurt D. Poulsen, Søren Priisholm, Thomas B. Raade, Torben Rex Sørensen og Jørgen Würtz

Red. af Olaf Michelsen 
D.G.U. Serie B, nr. 5

er sat med Foto Times

og trykt i offset i 1000 eksemplarer

hos AiO Tryk as, Odense

ISBN 87-421-0728-8

Date of publication 1981-12-31

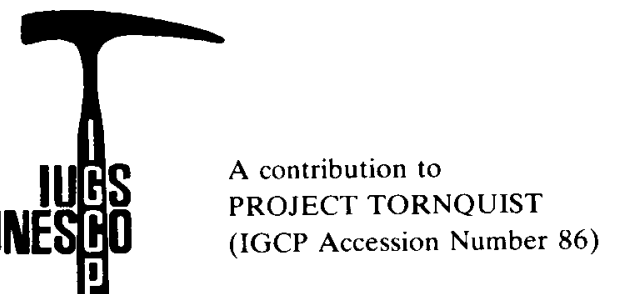




\section{Indhold}

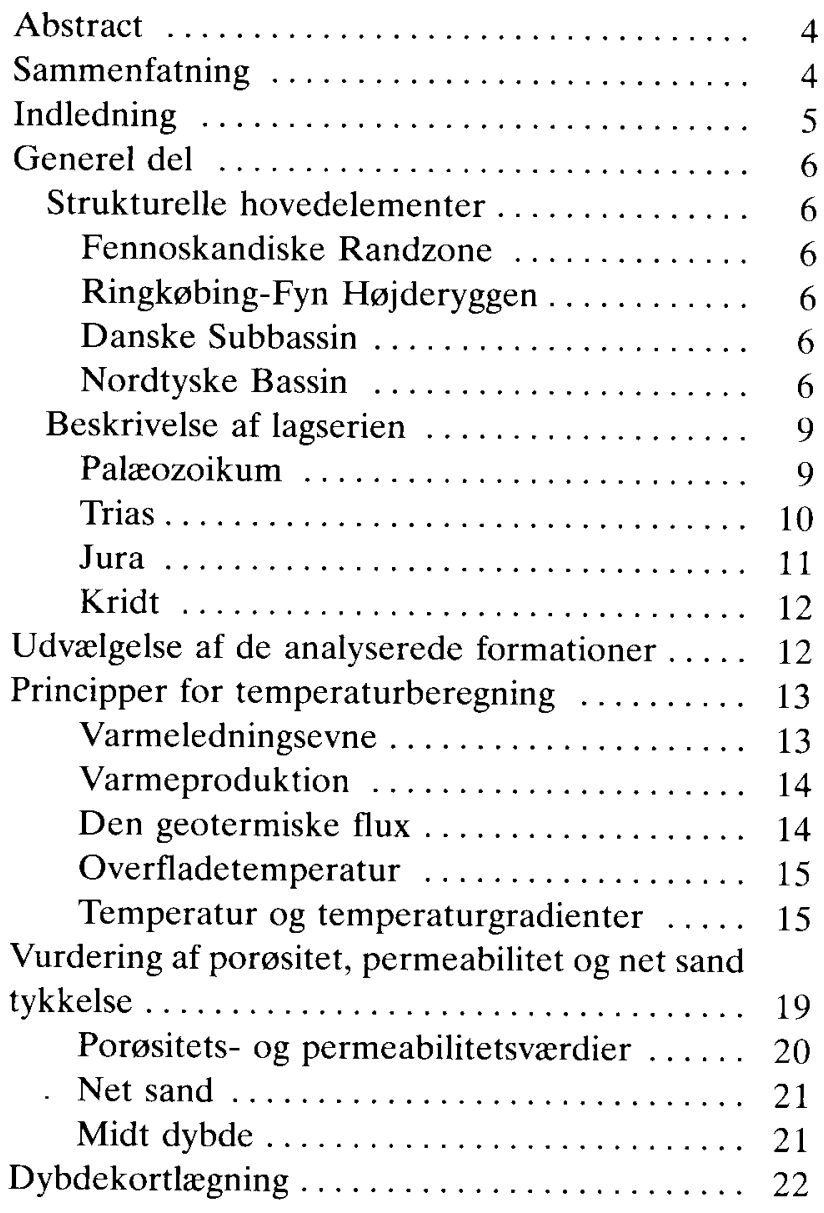

Beskrivelse af reservoirformationer ......... 23

Palæozoikum ..................... 23

Kambrisk kvartsitisk sandsten $\ldots \ldots \ldots \ldots 23$

Karbon kalksten ................. 23

Rotliegendes sandsten $\ldots \ldots \ldots \ldots \ldots 25$

Zechstein kalksten ................ 25

Trias ......................... 27

Bunter Sandsten Formation ........... 27

Ørslev Formation ................ 32

Falster Formation ............... 32

Tønder Formation ................ 35

Gassum Formation ............... 35

Jura-nedre kridt $\ldots \ldots \ldots \ldots \ldots \ldots \ldots \ldots, 45$

Haldager Sand .................. 45

Frederikshavn Member ............. 52

Hydrokemi ..................... 59

Regional reservoirkarakteristik $\ldots \ldots \ldots \ldots . \ldots 59$

Vurdering af reserverne $\ldots \ldots \ldots \ldots \ldots \ldots 65$

Tak ............................. 67

Acknowledgements ................... 67

English summary $\ldots \ldots \ldots \ldots \ldots \ldots \ldots \ldots, 68$

Litteratur ....................... 76

Appendix 1: Tabel over dybder, tykkelser, porøsiteter og permeabiliteter .............. 79

Appendix 2: Tabel og figurer over varmeledningsevne og varmeproduktion........... 85

Appendix 3: Beregningsresultater fra vurderingen af reserverne $\ldots \ldots \ldots \ldots \ldots \ldots \ldots \ldots, 92$ 


\section{Abstract}

The present report comprises primary data and analyses of potential geothermal reservoirs in Denmark. All available well data and seismic data from the Danish onshore area are included.

Based on core material and petrophysical measurements, the following formations are described: Cambrian quartsitic sandstone, Carboniferous limestone, Rotliegendes sandstone, Zechstein carbonates, Bunter Sandstone Formation (Triassic), Ørslev Formation (Triassic), Falster Formation (Triassic), Tønder Formation (Triassic), Gassum Formation (Triassic- L. Jurassic), Haldager Sand (M. Jurassic), and Frederikshavn Member (U. Jurassic - L. Cretaceous).

Generalized depth maps have been constructed for Near top Bunter Sandstones Formation, Near top Triassic, Base Haldager Sand, and Base Upper Cretaceous Limstone, from seismic two-way time maps of the relevant horizons.

Isotherm maps of the corresponding horizons, based on measured values (BHT) and new, calculated model values, are presented.

The reservoir parameters - porosity, permeability, net sand, and depth - have been analysed and evaluated from core material and petrophysical measurements. These data are presented in isopach maps of each formation, and in tables.

The regional distribution of potential reservoirs in the depth interval $2000-3000 \mathrm{~m}$ is described, and the geothermal reserves are evaluated, with regard to energy.

\section{Sammenfatning}

Nærværende rapport er baseret på analyser og fortolkninger af eksisterende dybdeboringsdata og seismiske data fra det danske landområde.

Rapportens første afsnit, »Generel del« «, omfatter en oversigtsmæssig beskrivelse af de geologiske, strukturelle, stratigrafiske og aflejringsmæssige forhold i den for undersøgelsen relevante del af lagserien. I det følgende afsnit redegøres der for baggrunden for udvælgelse af de her analyserede formationer. Alle kendte formationer under øvre kridts kalk- sten er inddraget i projektarbejdet, således at bearbejdningen er udtømmende for så vidt angår registrering af data og primær beskrivelse af formationernes reservoirkarakterer.

Metoder til vurdering af temperatur, de primære reservoirkarakterer som porøsitet, permeabilitet og net sand tykkelse, samt kortlægning af formationernes dybde behandles i tre særlige kapitler.

Vurderingen af temperaturer er baseret på teoretiske modeller og målte værdier i det omfang sådanne forefindes. Som grundlag for modelberegningerne er bjergartstermiske egenskaber målt på et stort antal borekerner. Samme kernemateriale er benyttet til måling af porøsitet og luftpermeabilitet. Væskepermeabilitet er kun målt i enkelte tilfælde. Porøsitet er desuden beregnet ud fra petrofysiske målinger (logs), der ligeledes er benyttet til vurdering af net sand tykkelser. Det har ikke været muligt inden for de afstukne rammer at undersøge mineralsammensætning, hærdning, dybde og lignende faktorers indflydelse på permeabilitet. Grundet manglende data er hydrokemiske aspekter kun kortfattet omtalt.

Der er foretaget seismisk kortlægning af enkelte fremtrædende reflektionshorisonter. På grundlag heraf er der fremstillet fire generaliserede dybdekort.

I afsnittet »Beskrivelse af reservoirformationer « gives der en oversigt over analyseresultaterne for de enkelte formationer: Dybde, tykkelse, net sand tykkelse, porøsitet, permeabilitet og temperatur. Beskrivelsen ledsages af kort indeholdende den regionale variation af disse parametre. Detaljerede tabeller findes $i$ appendix 1 og 2 .

Reservoirformationerne kan kort karakteriseres således. De palæozoiske formationer, kambrisk kvartsitisk sandsten, karbon kalksten og rotliegendes sandsten, er kun kendt fra et begrænset antal boringer. De skønnes ikke at være egnede geotermiske reservoirer.

Zechstein kalksten forekommende i Sydjylland kan lokalt muligvis udnyttes geotermisk.

De triassiske formationer, Bunter Sandsten Formation, Tønder Formation og Gassum Formation, vurderes alle som havende positive geotermiske reservoirkarakterer. Ørslev Formationen og Falster Formationen skønnes at have ringe reservoirkarakterer. 
Det jurassiske Haldager Sand forventes i begrænsede områder at have rimelig gode reservoirkarakterer, medens det jurassisk-nedre kretaciske Frederikshavn Member skønnes at have en begrænset værdi i geotermisk sammenhæng grundet den ringe dybde til lagene.

Afsnittet "Regional reservoirkarakteristik" er en konkluderende sammenfatning af ovennævnte beskrivelser inden for en ramme angivet af dybdeintervallet $2000-3000 \mathrm{~m}$. Opdelt på forskellige regioner beskrives hvilke formationer, der forekommer inden for dette dybdeinterval, og deres relative værdi i geotermisk sammenhæn angives.

Endelig gives der i afsnittet "Vurdering af reserverne" et resumé af, hvordan det geotermiske potentiel er vurderet. Her omtales de væsentligste forudsætninger for og resultater af den udførte analyse, hvis formål er at vurdere, hvor stor en del af de estimerede ressourcer, der ud fra et energimæssigt synspunkt kan udnyttes.

Litteraturlisten sidst i rapporten er sammenstillet således, at den omfatter den litteratur der skønnes relevant vedrørende geologi, geofysik og geotermisk energi i det danske område.

\section{Indledning}

I november 1976 nedsatte handelsministeriet en arbejdsgruppe, der skulle undersøge mulighederne for udnyttelse af geotermisk energi i Danmark. Ekspertgruppen bestod af repræsentanter fra Danmarks Geologiske Undersøgelse, Handelsministeriet, Energistyrelsen, Århus Universitet og Miljøstyrelsen. I februar 1977 fremkom gruppen med en rapport, der indeholdt både geologiske og hydrologiske vurderinger af udnyttelsesmulighederne samt et økonomisk overslag over udgifterne ved etablering og drift af et geotermisk anlæg.

Dansk Olie \& Naturgas A/S (D.O.N.G. A/S) fik i efteråret 1977 til opgave at lede det praktiske arbejde $\mathrm{i}$ forbindelse med efterforskningen, hvorefter D.O.N.G. A/S i 1978 fik eneretsbevilling. Som led i de nødvendige forundersøgelser nedsatte D.O.N.G. $\mathrm{A} / \mathrm{S}$ en arbejdsgruppe med en rådgivende funktion. I forbindelse med bevillingen til efterforskning blev der afsat 1,5 mill. kr. til mere forskningsprægede, landsdækkende undersøgelser af mulighederne for kommende geotermisk efterforskning og indvinding. Danmarks Geologiske Undersøgelse (DGU), Forsøgsanlæg Risø og Laboratoriet for Geofysik ved Aarhus Universitet (AU) fik til opgave at formulere et projekt af denne karakter, hvilket skete i foråret
1978. Projektet skulle gennemføres i perioden 1. juli 1978 til 31. december 1979 af de tre næunte institutioner og med projektledelsen hos DGU. Projektarbejdet blev i sommeren 1980 rapporteret i "Landsdækkende geotermiske Undersøgelser. Del 1 og 2 København 1980". Nærværende publikation er et forkortet optryk af denne rapport.

Vedrørende formål og sigte skal følgende kortfattede uddrag af projektbeskrivelsen gengives:

"Undersøgelsens formål er at foretage en landsdækkende vurdering af mulighederne for udnyttelse af geotermisk energi, herunder at søge lokaliseret de områder, der skulle frembyde de bedste muligheder for udnyttelsen. Undersøgelsen skal indeholde en analyse af eksisterende geologiske, geofysiske og geotermiske data, samt indsamling og bearbejdning af nye data".

"Geologiske og geotermiske parametre vil blive beskrevet bl.a. i form af kort over reservoirernes dybde, tykkelse og udbredelse. Kort over porøsiteter, permeabiliteter, petrografi, termiske egenskaber og temperaturer vil blive fremstillet for de enkelte reservoirer".

Undersøgelsen har først og fremmest omfattet en registrering af data, analyse og beskrivelse af primære reservoirparametre og en oversigtlig sammenstilling af disse. Grundet manglende tid og ressourcer er videnskabelig analyse af parametrenes variation $i$ forhold til forskellige faktorer, så som aflejringernes faciesvariation og diagenese, kun foretaget $\mathrm{i}$ begrænset omfang.

Ved DGU er ca. $700 \mathrm{~m}$ borekerner, repræsenterende alle nedennævnte reservoirformationer, blevet nybeskrevet med særlig henblik på kornstørrelsesfordeling og facies. Et tilsvarende stort antal plugs er udboret for måling af porøsitet og luftpermeabilitet. Med de forhåndenværende midler har det desværre kun været muligt $\mathrm{i}$ begrænset omfang at foretage analyse af væskepermeabilitet. Sammenholdt med disse data er for samtlige eksisterende boringer fortolket petrofysiske målinger til vurdering af net sand tykkelser i de enkelte formationer og af gennemsnitlige værdier for porøsitet og permeabilitet (luft). Disse reservoirparametre er i nærværende rapport fremstillet i tabel- og kortform. Primært ud fra borehulsdata er der foretaget en kortlægning af reservoirformationernes dybde og tykkelse. Arbejdet er udført af Lise Holm, Jens Ole Koch, Olaf Michelsen, Erik Nygaard, Gunver K. Pedersen og Søren Priisholm.

DGU har yderligere foretaget dybdekortlægningen baseret på seismiske målinger. Med enkelte mindre undtagelser er alt eksisterende seismisk materiale 
blevet fortolket og 4-5 horisonter kortlagt i "tid", der er den enhed hvori den seismiske måling foretages. Via analyse og beregning af hastighedsfunktioner er de fire horisonter vurderet og kortlagt m.h.t. dybde i meter. For så vidt angår Sjælland er arbejdet udført af Claus Andersen, medens kortlægning af Jylland er foretaget af Jens Christian Olsen og Torben Rex Sørensen under vejledning af J. C. Baartman.

Laboratoriet for Geofysik, Aarhus Universitet, har foretaget bestemmelser af temperaturer for de aktuelle formationer og dybdeniveauer. Temperaturvurderingen er baseret på teoretiske modeller og målte værdier, hvor sådanne findes. Som grundlag for modelberegningerne er der målt bjergartstermiske egenskaber på DGU's kernematerialer. Der er udviklet og bygget nyt apparatur til varmeledningsevnebestemmelser og til nøjagtige målinger af temperaturer $\mathrm{i}$ dybe boringer og beregninger af temperaturgradienter. Arbejdet er udført af laboratoriets geotermiske arbejdsgruppe bestående af $\mathrm{N}$. Balling, N. Breiner, J. I. Kristiansen, K. Damtoft Poulsen og Svend Saxov.

På grundlag af den geologiske og geofysiske undersøgelse er der foretaget en vurdering af det geotermiske potentiel. Her er vurderet, hvor stor del af de estimerede ressourcer, der ud fra visse rimelige kriterier er udnyttelige ud fra et energimæssigt synspunkt. Der er ikke draget økonomiske hensyn med ind i vurderingen; dog er tekniske løsninger, der på forhånd må anses for økonomisk prohibitive, udeladt.

Vurderingen, der er udført på Forsøgsanlæg Risø af Knud Jensen, Jørgen A. Leth, Thomas B. Raade og Jørgen Würtz, bygger på en opdeling af de geologiske formationer i en række afgrænsede områder. Til brug for vurderingen er reservoiregenskaberne antaget konstante $\mathrm{i}$ de enkelte områder. Inden for hvert område er vurderet, hvor meget energi der netto kan udvindes, og en summering over samtlige områder er foretaget.

Projektledelse og redaktion er varetaget af Olaf Michelsen.

\section{Generel del}

Som baggrund for udvælgelsen og analyseringen af formationer med henblik på en eventuel geotermisk efterforskning beskrives nedenfor den geologiske opbygning i Danmarks undergrund. Analyse af den strukturelle, sedimentologiske og facielle udvikling er en nødvendig forudsætning for det kommende arbejde på dette felt.

Til støtte for forståelsen af nærværende kapitel og "beskrivelse af reservoirformationer" er de strukturelle hovedelementer vist i fig. $1 \mathrm{og}$ den stratigrafiske inddeling i fig. 2.

\section{Strukturelle hovedelementer}

Danmarks undergrund i undersøgelsesområdet kan inddeles i følgende strukturelle hovedelementer (fig. 1):

Den fennoskandiske Randzone danner den nordvestlige del af det regionalt overordnede Tornquist-Teisseyre lineament, som kan spores mod sydøst helt til Sortehavet. Dette lineament adskiller den stabile østeuropæiske prækambriske og palæozoiske platform fra de yngre nordvesteuropæiske sedimentære bassinområder. Den fennoskandiske Randzone er en kompliceret opbygget blokforkastningszone med en udviklingshistorie, der er dokumenteret at gå tilbage til tidsrummet øvre karbon-nedre perm, og at spille en væsentlig rolle under de mesozoiske (kimmeriske) og tertiære (laramiske) tektoniske faser. I det danske område strækker denne zone sig fra Vendsyssel i nord mod sydøst gennem Kattegat, Skåne til den sydlige Østersø. Bornholm udgør en isoleret horst placeret $\mathrm{i}$ randzonen.

Ringkøbing-Fyn Højderyggen, Stevns- og Møn Blokkene tilhører et regionalt VNV-ØS $\varnothing$-gående strøg af højdeområder og "øer" gennemskåret af rift strukturer og mindre trug. Dette strøg kan følges til den britiske del af Nordsøen og er karakteriseret af højtliggende grundfjeld. Således er præ-kambrisk grundfjeld blevet anboret i mindre end $900 \mathrm{~m}$ dybde ved Glamsbjerg på Fyn beliggende centralt på Højderyggen.

I det danske område adskiller Ringkøbing-Fyn Højderyggen Det danske Subbassin (del af det større Norsk-danske Bassin) mod nord fra Det nordtyske Bassin mod syd.

Dette strukturelle mønster er anlagt i løbet af nedre perm og kan illustreres ved de generaliserede dybde-konturer til præ øvre perm overfladen samt ved den formodede udbredelse af aflejringer fra zechstein (øvre perm) (fig. 1). Indsynkningen i bassinernes centrale dele har været betydelig i de efterfølgende perioder. Således viser seismiske målinger, at der siden nedre perm er aflejret mere end 8000 $9000 \mathrm{~m}$ sedimenter centralt i Det danske Subbassin (vestligste Himmerland og Hanherred).

I lighed med perm perioden er det sandsynligst, at dele af Ringkøbing-Fyn Højderyggens grundfjelds- 


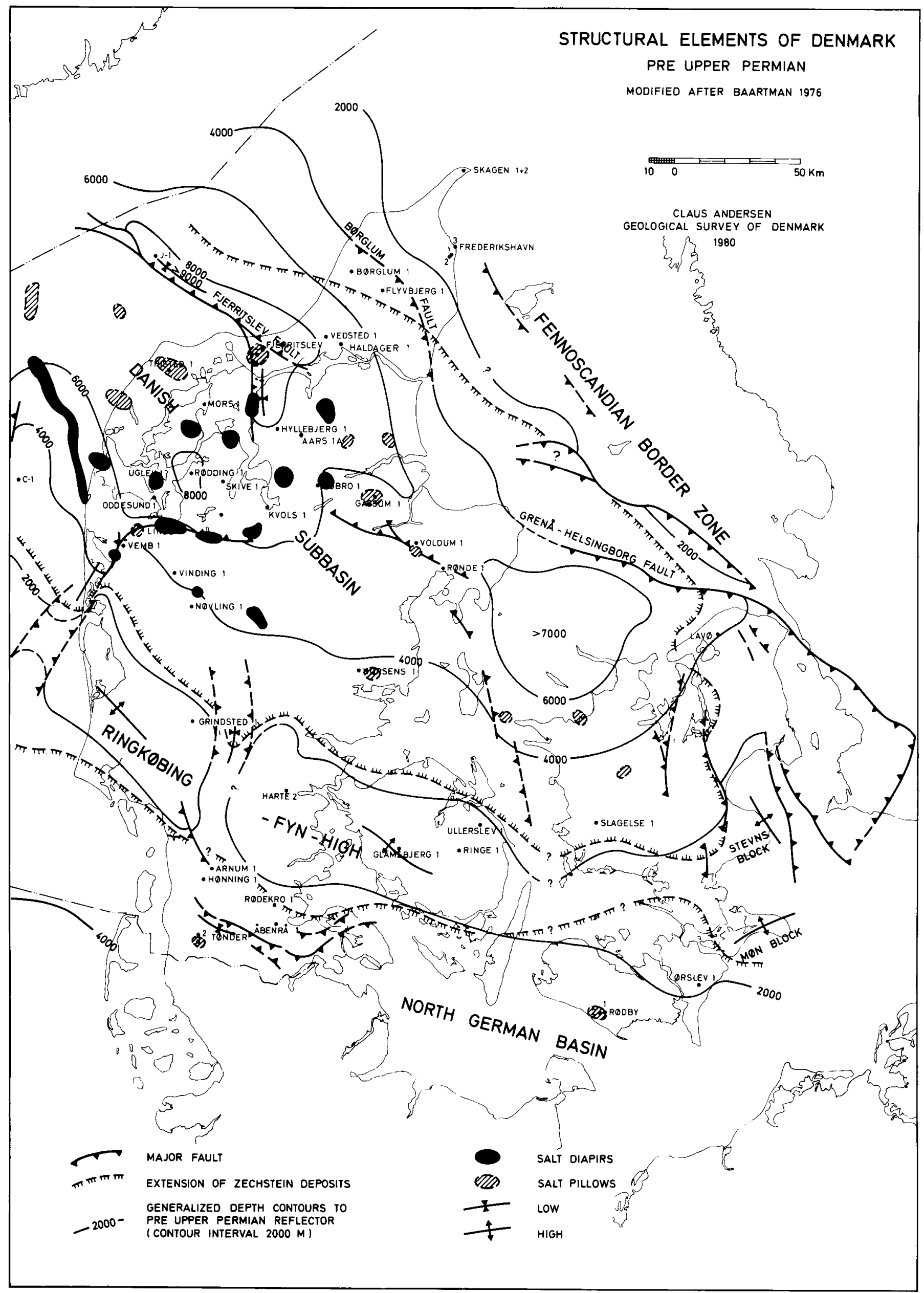

Fig. 1. Hovedstrukturelelementerne samt dybde i meter til lagene under øvre perm. 


\begin{tabular}{|c|c|c|}
\hline SYSTEM & SERIE & ETAGE \\
\hline \multirow{3}{*}{$\begin{array}{l}\stackrel{5}{a} \\
\underset{\sim}{x}\end{array}$} & \multirow{3}{*}{ 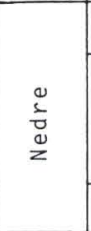 } & Albien \\
\hline & & $\begin{array}{l}\text { Aptien } \\
\text { Barremien } \\
\text { Hauterivien } \\
\text { Valanginien }\end{array}$ \\
\hline & & Berriasien \\
\hline \multirow{7}{*}{$\begin{array}{l}\stackrel{\nwarrow}{\cong} \\
\stackrel{亏}{丂}\end{array}$} & $\begin{array}{l}0 \\
\stackrel{0}{a} \\
a\end{array}$ & $\begin{array}{l}\text { Portlandien } \\
\text { Kimmeridgien } \\
\text { Oxfordien }\end{array}$ \\
\hline & $\frac{E}{\frac{E}{E}}$ & $\begin{array}{l}\text { Callovien } \\
\text { Bathonien } \\
\text { Bajocien }\end{array}$ \\
\hline & \multirow{5}{*}{$\begin{array}{l}0 \\
\frac{1}{0} \\
\frac{0}{2}\end{array}$} & $\begin{array}{l}\text { Aalenien } \\
\text { Toarcien }\end{array}$ \\
\hline & & ø. pliensbachien \\
\hline & & N. pliensbachien \\
\hline & & ø. sinemurien \\
\hline & & N.sin.-hettangien \\
\hline \multirow{5}{*}{ 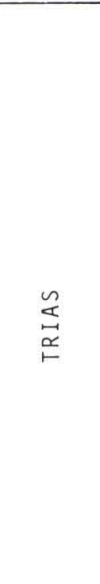 } & \multirow[b]{2}{*}{$\begin{array}{l}\stackrel{0}{2} \\
\frac{2}{3}\end{array}$} & $\begin{array}{l}\text { Rhaetien } \\
\text { Norien }\end{array}$ \\
\hline & & Carnien \\
\hline & \multirow{2}{*}{$\frac{\frac{E}{\omega}}{\frac{E}{2}}$} & Ladinien \\
\hline & & Anisien \\
\hline & $\begin{array}{l}\frac{0}{2} \\
\frac{0}{0} \\
\frac{0}{2}\end{array}$ & $\begin{array}{l}\text { Olenikien } \\
\text { Jakutien } \\
\text { Brahmanien }\end{array}$ \\
\hline
\end{tabular}

\begin{tabular}{|c|c|}
\hline FORMATION & MEMBER \\
\hline \multicolumn{2}{|l|}{ ø.kridt kalksten } \\
\hline \multicolumn{2}{|l|}{ Rødby Formation } \\
\hline \multicolumn{2}{|l|}{ Vedsted Formation } \\
\hline \multirow[t]{2}{*}{ Bream Formation } & $\begin{array}{l}\text { Frederikshavn } \\
\text { Member }\end{array}$ \\
\hline & Børglum Member \\
\hline \multirow{2}{*}{$\underset{\text { Haldager }}{\underset{\text { Forma- }}{\text { tion }}}$} & Flyvbjerg Member \\
\hline & Haldager Sand \\
\hline \multirow{4}{*}{$\begin{array}{l}\text { Fjerritslev } \\
\text { Formation }\end{array}$} & Member F-IV \\
\hline & Member F-III \\
\hline & Member F-I I \\
\hline & $\begin{array}{ll}\text { Member F-I } & b \\
a\end{array}$ \\
\hline Gassum Formation & Member $G_{0}-G_{4}$ \\
\hline \multicolumn{2}{|l|}{ Vinding Form. } \\
\hline \multirow{4}{*}{ 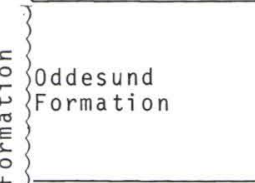 } & Member $\mathrm{O}_{3}$ \\
\hline & Evaporit \\
\hline & ${ }_{2}{ }^{2}$ Evaporit \\
\hline & Member $0_{1}$ \\
\hline$\underset{r}{*}$ Tonder Form. & \\
\hline ¿ Falster Form. & \\
\hline 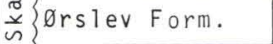 & \\
\hline$\left\{\begin{array}{l}\text { Bunter Sandsten } \\
\text { Formation }\end{array}\right.$ & \\
\hline $\begin{array}{l}\text { Bunter Lersten } \\
\text { Formation }\end{array}$ & \\
\hline
\end{tabular}

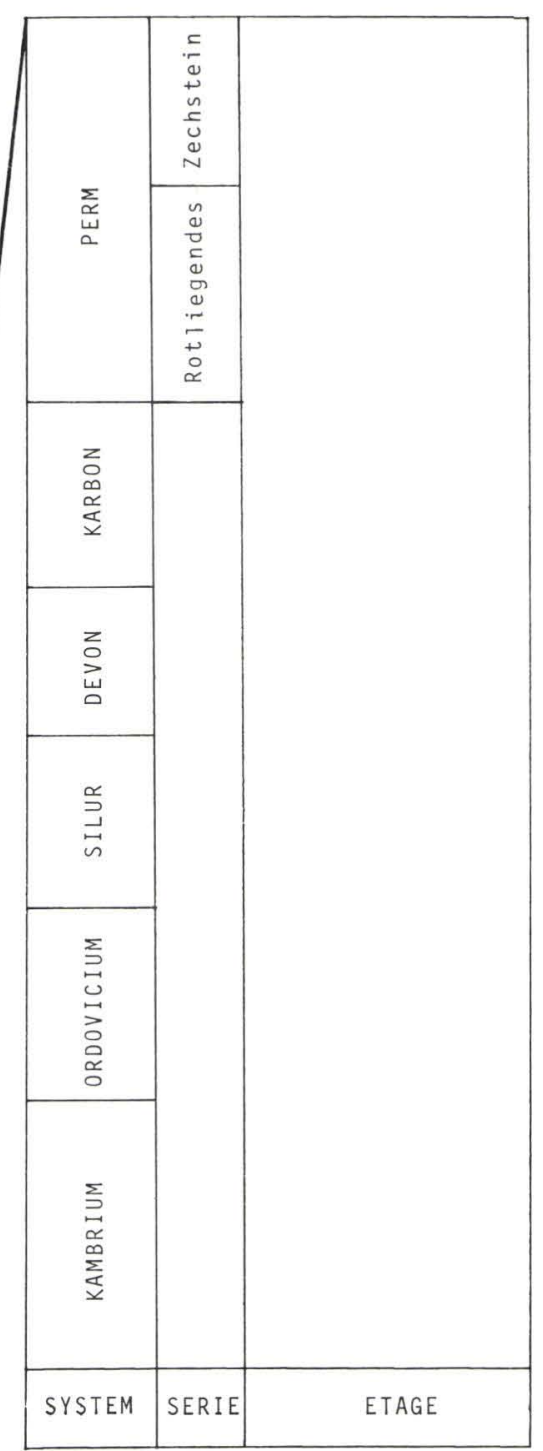

Stensalt, kalksten

Sand-, silt-, lersten,

vulkanske bjergarter

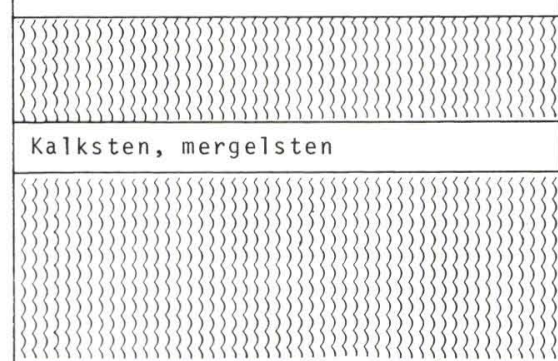

Silt-, lersten,

vulkanske bjergarter

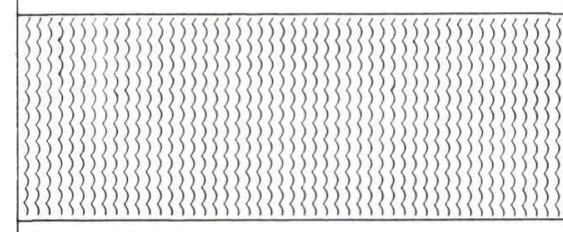

Lerskifer

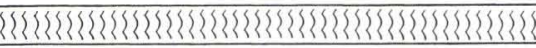

Siltsten

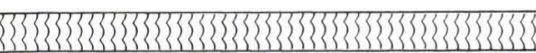

Kvartsit

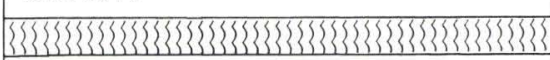

BJERGARTSTYPE

STRATIGRAFISK STANDARDINDDELING AF DEN DANSKE UNDERGRUND 
kerne har ligget blottet som "øer" i den ældste del af trias, og at de to bassiner har da kun været forbundne via mindre trug. I løbet af mellem trias synker Højderyggen og der opstår et sammenhængende aflejringsområde. Indsynkningen af Højderyggen har dog været beskeden sammenlignet med indsynkningen af de egentlige bassiner, idet sedimenterne tynder stærkt ud over denne. Denne udvikling fortsætter til udgangen af nedre jura, hvor der sker en større regional hævning af det danske område. I den efterfølgende såkaldte midt kimmeriske tektoniske fase (mellem jura) hæves Højderyggen og der finder en intensiv erosion sted over dens centrale dele. I bassinerne fortsætter indsynkningen. Ved udgangen af øvre jura finder endnu en regional hævning sted og efter denne fortsætter indsynkningen inklusive Ringkøbing-Fyn Højderyggen, der således også dækkes af aflejringer fra den yngste del af nedre kridt, øvre kridt og teriær. Ved overgangen øvre kridt-tertiær (den laramiske tektoniske fase) hæves hele zonen langs Den fennoskandiske Randzone nordøst for de markante Fjerritslev og Grenå-Helsingborg forkastningszoner. Herefter sker et skift i det strukturelle mønster i den ældste del af tertiær, idet den resterende del af det danske område nu bliver en del af det større skålformede Nordsø Bassin og Ringkøbing-Fyn Højderyggen mister endelig sin betydning.

Hovedparten af de sedimenter, der i trias-jura perioderene er aflejret i den danske del af Det nordtyske Bassin og Det danske Subbassin består af klastisk materiale (ler, silt og sand) der i det sidstnævnte Subbassin hovedsagelig er tilført fra nord og øst af skiftende floder og vandløb. Dette indebærer, at de mest grovkornede aflejringer generelt skal søges i et bælte langs Det danske Subbassins nord- og østrand.

Synsedimentære forkastningsaktiviteter i Fjerritslev og Børglum Forkastningerne forekommer bl.a. i trias. Således har den successive nedforkastning af blokkene nord for Fjerritslev Forkastningen medført sedimentation af relativt store mægtigheder af grovklastisk materiale.

Saltstrukturer er et karakteristisk element både $\mathrm{i}$ Det danske Subbassin og i Det nordtyske Bassin. Specielt i den nordjyske salthorst provins kendes mere end 10 saltdiapirer, hvor stensalt forekommer på ringe dybde. Her er ved inddampning af havvand i zechstein perioden aflejret $500-1200 \mathrm{~m}$ stensalt, som i de efterfølgende perioder er blevet overlejret af sedimenter med en tykkelse på adskillige kilometer.

Som følge af stensalts relativt lavere massefylde og høje plasticitet kan denne bjergart starte horisontale og vertikale bevægelser ved overlejring af tykke sedimentserier. Første stadium i saltbevægelsen vil være dannelse af bløde opbulninger (saltpuder) og ved fortsat bevægelse vil der dannes stejltstillede saltdiapirer, som bryder igennem de overliggende lag. Ved saltmigration i undergrunden $i$ retning af saltstrukturerne udvikles omkring strukturerne lokale indsynkninger, hvor sedimenttykkelsen bliver anormalt stor (randsynklinaler). Tilsvarende vil der ske en udtynding af sedimenterne på toppen af en saltstruktur i løbet af dens udviklingshistorie.

I Nordjylland formodes saltbevægelserne at være startet i keuper (øverste trias) og fortsat op i nutiden.

\section{Beskrivelse af lagserien}

I enkelte boringer på Ringkøbing-Fyn Højderyggen og nord for Det danske Subbassin er der fundet gnejs af prakambrisk alder. Umiddelbart over gnejsen er der fundet arkoser og konglomerater. De er af ukendt alder og må forventes at dække grundfjeldet $\mathrm{i}$ store områder. Ligeledes af ukendt alder findes i Sønderjylland siltsten og lersten umiddelbart under zechsteinaflejringerne.

\section{Palæozoikum}

Aflejringer ældre end zechstein saltserien er kun truffet $i$ enkelte boringer, hvorfor en vurdering af deres regionale udbredelse er meget usikker. Nedenfor vil derfor kun deres dokumenterede forekomst blive omtalt.

I boringen Slagelse 1 findes nederst lag fra $\mathrm{kam}$ brium perioden. Det drejer sig om de nedre kambriske kvartsitiske sandsten og lerede siltsten. Øvre kambrium er repræsenteret ved mørke lerskifre (alunskifer).

Siltsten og lersten af silur alder er fundet $i$ tre boringer nord for Ringkøbing-Fyn Højderyggen. I to af boringerne, Rønde 1 og Nøvling 1, findes tillige vulkanske bjergarter af nedre silur alder.

Kalksten, mergelsten og røde til grå lersten af nedre karbon alder er kun truffet $\mathrm{i}$ boringen Ørslev 1 .

Med større regional udbredelse er der under zechstein stensaltlagene truffet rødlige og rødbrune lersten, siltsten og sandsten af formodet rotliegendes alder. Disse non-marine aflejringer må formodes at dække større områder på begge sider af højderyggen. Enkelte steder er forekomst af vulkanske bjergarter konstateret.

Ved overgangen til øvre perm, zechstein, var Det nordtyske Bassin og Det danske Subbassin dannet og inddampningsbjergarter som stensalt, anhydrit og kalksten aflejredes cyclisk. Marginalt, bl.a. langs Højderyggens flanker, dannes revkalk. 
Trias

Den nedre triassiske buntsandstein serie repræsenterer en regressiv periode gennem hvilke overvejende kontinentale aflejringsforhold var fremherskende i det nordvesteuropæiske sedimentationsområde.

I buntsandstein var Danmark opdelt i en leret provins, dækkende Det nordtyske Bassin, RingkøbingFyn Højderyggen og den sydøstlige del af Det danske Subbassin, og en sandet provins, dækkende den centrale og nordvestlige del af Det danske Subbassin. Mellem de to provinser er der en gradvis overgang, som er iagttaget i boringerne Rønde 1, Gassum 1 og Mors 1.

I den lerede provins består nedre buntsandstein (Bunter Lersten Formation) overvejende af rødlig brun og brun, siltholdig lersten med grønlige partier samt spredte forekomster af anhydrit. Mellem buntsandstein (Bunter Sandsten Formation) minder om nedre buntsandstein, men karakteriseres af forekomsten af 2-3 velafgrænsende lagserier af siltsten og finkornet sandsten, der mod nord går over i én sandet enhed. Øvre buntsandstein ( $\emptyset$ rslev Formation) repræsenteres af grønlig grå og brunlig lersten vekslende med anhydrit og kalksten, samt sydligst med stensalt.

I modsætning til den lerede provins er lithologien $\mathrm{i}$ den sandede provins forholdsvis ensartet bestående af rødlig, leret, arkoselignende sandsten. Denne facies udgør den nedre del af Skagerrak Formationen, som er betegnelsen for de monotone, sandede, triassiske randaflejringer langs nord- og østranden af Det danske Subbassin.

Buntsandstein serien består mod nord hovedsagelig af kontinentale, fluviatile aflejringer afsat under aride til semi-aride forhold. Mod syd veksler kontinentale lag med brakvandsaflejringer. Sandfordelingen indicerer, at materialet ensidigt er transporteret fra nord og nordøst ind i bassinerne. De bedste reservoirbjergarter findes derfor antageligt i et bælte langs den nordlige og østlige rand af Det danske Subbassin.

Orslev Formationens nedre del i den lerede provins repræsenterer lavvandede brakt-marine transgressioner kommende fra sydøst. På grund af det tørre, varme klima har vandbalancen i perioder været overvejende negativ, dvs. at fordampningen har været større end vandtilførslen, hvorved de opløste salte er udfældet og danner markante lag. Den øvre del af serien er kontinentalt præget. Den har ingen reservoirmæssig betydning.

Den mellem triassiske Falster Formation består af vekslende lersten, mergelsten og kalksten med spredte forekomster af anhydrit. Sedimentfarven er overvejende grågrøn og grå, sjældnere brun og rødlig.
Den nedre del af formationen er generelt rigere på kalksten, der ofte er fossilførende. Mod nord afløses formationen gradvist af Skagerrak Formationens sandsten. Formationens nedre lag er marine, medens den øvre del må tolkes som en lavvandet, periodevis tørlagt brakvandsdannelse. Formationen har næppe reservoirmæssig betydning, men de jævnaldrende sandsten i Skagerrak Formationen vil antagelig kunne udnyttes.

Tønder Formationen minder stærkt om buntsandsteinserien. Formationen består af rødlig brun, brun og grønlig, siltholdig lersten med spredte anhydritindeslutninger, samt øverst i formationen af enkelte velafgrænsede lag af siltholdig, finkornet rødbrun og grågrøn sandsten, der ofte indeholder fint, forkullet plantemateriale. Mod nord tiltager sandindholdet og formationen går gradvist over i Skagerrak Formationen. Tønder Formationen består overvejende af kontinentale dannelser afsat under et tørt og varmt klima. Sandstensdannelserne øverst i formationen tyder på perioder med forøget nedbør. Sandstenslagene er potentielle reservoirer, medens den nedre del af formationen ikke kan tillægges nogen betydning $i$ denne sammenhæng.

Oddesund Formationen består af lersten og siltsten, rødbrun, brun og grå, med enkelte anhydritindeslutninger og tynde lag af mergelsten og dolomitisk kalksten. I den centrale del af Det danske Subbassin forekommer to veludviklede serier af stensalt. Mod bassinranden afløses de to serier af anhydritrig lersten. Formationen er helt eller delvis borteroderet over dele af Ringkøbing-Fyn Højderyggen. Langs nordranden af Det danske Subbassin fortsætter sandsedimentationen (Skagerrak Formationen). Aflejringerne består af vekslende kontinentale dannelser og brakvandsdannelser præget af et varmt og tørt klima. De to evaporitserier viser at fordampningen i to perioder har oversteget vandtilførslen til bassinet.

Under aflejringen af disse sedimenter begynder pudedannelsen i perm saltet, og formationen er derfor af uens tykkelse.

Vinding Formationen består af vekslende lersten og kalksten. Lerstenen er kalkholdig med et varierende saltindhold. Mørkegrå til sort olivengrå farver dominerer. Anhydrit forekommer sporadisk i den nedre del. Kalkstenslagene findes på bestemte niveauer $\mathrm{i}$ serien og kan genkendes fra boring til boring. Nederst i formationen findes grå og brune, dolomitiske kalksten, medens den midterste del karakteriseres af grå og brune, oolitiske kalksten, og den øverste af tynde bånd af dolomitisk kalksten.

Serien er aflejret i brakvand med generelt ringe vanddybde. Medens kystnære forhold med periodisk 
udtørring synes at have hersket $\mathrm{i}$ den tidlige fase, må den øvre del af formationen betragtes som prodelta lersten afsat på noget dybere vand og tilhørende det nedenfor nævnte Gassum Delta, som opbyggedes i forbindelse med en klimaændring fra tørre til mere nedbørsrige klimaforhold ved slutningen af triastiden.

Formationen er impermeabel og derfor uden reservoirmæssig betydning.

Gassum Formationen består overvejende af fint til mellemkornede, lysegrå sandsten, der veksler med mørkere lersten og siltsten. Kullag forekommer spredt. Formationen underinddeles i tre enheder (members), men lokalt kan yderligere enheder forekomme. Den nederste enhed $\left(G_{1}\right.$ Member $)$ har gode reservoiregenskaber og er typisk udviklet som en serie, der nederst består af lersten, siltsten og opefter af sandsten med tiltagende grovkornethed. Den overliggende enhed $\left(\mathrm{G}_{2}\right.$ Member) domineres af organisk rige, mørke lersten med underordnet forekomster af siltsten og lersten. Den øverste enhed $\left(G_{3}\right.$ Member $)$ består af grå og rødlige lersten overlejret af lyse grønliggrå sandsten og siltsten, der ofte indeholder glaukonit.

Gassum Formationen er tolket som en fluviatildeltaisk aflejring. $G_{1}$ Member må opfattes som aflejringer fra det såkaldte Gassum Delta. Det drejer sig om delta-front dannelser med tiltagende kornstørrelse op gennem serien i de centrale og sydlige dele af bassinet. Mod top af enheden er sandet aflejret i fletværkskanaler efterfulgt af organisk rige lag afsat i afsnørede bugter og kanaler. $\mathrm{G}_{2}$ Member ses som brakt-marine aflejringer, der stammer fra en stigning af havniveauet, hvorved deltafladen druknede. Det store indhold af organisk materiale er bevaret grundet et lavt iltindhold ved havbunden. $G_{3}$ Member repræsenterer en regressiv fase (faldende havniveau) hvor limniske betingelser kom til at herske i store dele af bassinet. Den øvre glaukonitførende silt- og sandsten i dette member er dog dannet ved den begyndende nedre jurassiske transgression, der førte til dannelsen af Fjerritslev Formationen (se nedenfor). Gassum Formationen er vurderet til at have gode reservoirkarakterer.

\section{Jura}

På overgangen mellem trias og jura starter en fornyet indsynkning af Det danske Subbassin og aflejring af de nedenfor beskrevne marine lersten tager sin begyndelse i den centrale del af bassinet. Aflejring af de fluviatil-deltaiske sedimenter kaldet Gassum Formationen fortsætter mod nordøst $\mathrm{i}$ begyndelsen af jura. I
Vendsyssel er store dele af Gassum Formationen således af nedre jurassisk alder.

Den nedre jurassiske Fjerritslev Formation består af ensartede, mørke lersten med varierende indhold af silt.

Lagserien er en marin shelf aflejring afsat under indsynkning af bassinet. Den nederste del er en lavtvandsserie med tynde kalk- og siltlag aflejret samtidig med dannelsen af Gassum Formationen i Vendsyssel. Hovedparten af Fjerritslev Formationen er afsat på dybere vand, medens øverste del atter er en lavtvandssedimentation, der antagelig har fundet sted under lagunale betingelser. Formationen har ikke reservoirmæssig karakter.

På overgangen nedre-mellem jura hæves områderne langs Ringkøbing-Fyn Højderyggen og dele af eller hele Fjerritslev Formationen borteroderes. Den relative sænkning af havniveauet i mellem jura medfører at tilførselskanalerne mod nordøst bygger et delta ud i bassinet, Haldager Deltaet. I denne periode aflejres deltaaflejringer og kystnære havaflejringer i form af Haldager Formationen.

Den nederste del af Haldager Formationen, kaldet Haldager Sand, består af lysegrå, fint til mellemkornet sandsten og siltsten, der oftest er homogen og velsorteret. Krydslejring forekommer. Tykke lag af sandsten veksler med tynde lerlag og enkelte kullag. I den nordøstlige del af området, hvor lagserien har sin maximale tykkelse, kan den opdeles i flere underenheder svarende til rytmisk skiftende aflejringsbetingelser. Lagserien vurderes som havende reservoirkarakterer. Den overlejres af Flyvbjerg Member, der er en vekslende lagserie med forholdsvis tynde lag af sandsten, siltsten og lersten. Den reprasenterer hastigt skiftende aflejringsbetingelser, der har hersket på delta-fladen ved havets gradvise overskylning af denne.

Den øverste del af Flyvbjerg Member er af øvre jurassisk alder, og repræsenterer dermed begyndelsen af bassinets anden indsynkningsperiode $\mathrm{i}$ jura. Under denne indsynkning afsættes Børglum Member, der er en marin lerstens serie aflejret på den dybere del af shelfen. Den er uden reservoirmæssig betydning. Den største indsynkning finder sted i den centrale del af bassinet og mod vest i Nordsøen. Mod nordøst, i Vendsyssel, har der kun været tale om en kortvarig periode, hvorefter kystnære litoral-deltaiske forhold atter hersker. Dette er en følge af at der på overgangen mellem jura og kridt atter sker en hævning af området og mængden af groft materiale, der føres ud i bassinet, stiger, hvorved Frederikshavn Member dannes. Serien består af siltsten og finkornet sandsten, der veksler med siltholdig lersten. Tynde lag af kalksten forekommer i den øverste og nederste 
del af serien. Længst mod nordøst i Vendsyssel findes der få cm-tykke kullag i den øvre del af serien. Lagserien antages at have moderat gode reservoirkarakterer.

Lagserien er overvejende en marin aflejring. Mod øst og nordøst er den meget tyk og repræsenterer et stort tidsinterval, medens den mod vest er tyndere (antagelig repræsenterende et mindre tidsinterval) og er mere finkornet. Lagserien afspejler således en generel sænkning af havniveauet $i$ store dele af øvre jura og nedre del af nedre kridt. Mod nordøst er den nedre og øvre del af serien karakteriseret ved at indeholde fossiler og glaukonit, medens den midterste del indeholder en stigende mængde plantemateriale, der er vasket ud i bassinet fra landområderne mod øst.

\section{Kridt}

I løbet af nedre kridt sker der atter en indsynkning af Det danske Subbassin, og i den sidste del af perioden oversvømmer havet hele det danske område således, at de yngste nedre kridt aflejringer dækker henover Ringkøbing-Fyn Højderyggen og her hviler på lag af trias alder.

I Det danske Subbassin er Vedsted Formationen aflejret over Frederikshavn Member og består af mørkegrå ler- og siltsten. Det er en marin aflejring, der i de kystnære områder mod nordøst veksler med mere grovkornede sedimenter.

Mod slutningen af nedre kridt andrer sedimentationen karakter på to måder. For det første oversvømmes som nævnt hele landet. For det andet bliver sedimenterne stærkt kalkholdige. Det drejer sig primært om Rødby Formationen, som overvejende består af rødbrun mergel. Den dækker hele landet bortset fra Vendsyssel, hvor den erstattes af grønlige, glaukonitholdige sedimenter. Vedsted og Rødby Formationerne har ingen reservoirmæssig betydning, medens de randnære sandstensaflejringer antagelig er gode men højtliggende reservoirer.

I sidste del af nedre kridt perioden er indledt en ny hovedfase, idet Ringkøbing-Fyn Højderyggen atter dækkes af havet. Klimaet bliver atter tørt og varmt, og havet tilføres derfor kun ringe mængder ler og sand. I stedet bundfældes slamkalk bestående af skeletdele fra planktoniske mikroorganismer, - øvre kridts hvide kalksten. Den nederste del af denne kalkstensserie, der $\mathrm{i}$ begrænsede områder ligger relativt dybt, har kun middelmådige reservoirkarakterer.

\section{Udvælgelse af de analyserede formationer}

Som omtalt $\mathrm{i}$ indledningen og som det fremgår af litteraturfortegnelsen er der siden 1977 skrevet enkelte rapporter om muligheden for indvinding af geotermisk energi i Danmark. Der er i denne forbindelse peget på forskellige lag $\mathrm{i}$ undergrunden, som kunne være genstand for kommende undersøgelser, efterforskning og exploration. Ved tilrettelæggelsen af nærværende projekt blev det besluttet at gøre alle disse formationer til genstand for analyse og vurdering og på den måde at give en samlet oversigt over disse formationers reservoirparametre.

De pågældende formationer findes i lagserien fra basis af den øvre kretaciske kalksten til top af grundfjeldet. Der er således indbefattet lag, som i visse dele af landet ligger for dybt til på nuværende tidspunkt at være genstand for efterforskning af geotermisk energi. Øvre kridt kalkstenen er ikke indbefattet i undersøgelsen, primært fordi den i størstedelen af landet ikke ligger dybt nok til at have en passende temperatur. Dertil kommer som nævnt ovenfor, at den nedre del af kalkstensserien skønnes at have middelmådige reservoirkarakterer.

Erkendelsen af mulige reservoirformationer baseres primært på petrofysiske målinger fra eksisterende boringer. Disse er foretaget over en lang årrække. Kvaliteten af målingerne er derfor meget varierende, og for en dels vedkommende giver de kun begrænset mulighed for en forholdsvis sikker vurdering. Detaljerede analyser af ældre og nyere målinger, suppleret med analyse af eventuelle borekerner, har i nærværende projekt givet en mere nuanceret og detaljeret beskrivelse af formationer (se nedenfor).

De palæozoiske formationer kendes kun fra få boringer og deres regionale udbredelse og variation er lidet kendt. Det drejer sig om kalkstens- og sandstensaflejringer.

De triassiske formationer kendes fra en række boringer og forekommer med enkelte undtagelser over hele landet. Det drejer sig om fem formationer, som i større eller mindre udstrækning er præget af sandstensforekomster. Sandstenslagenes tykkelse og sand/ler forholdet, som bl.a. har været genstand for nærværende undersøgelser, varierer både vertikalt og horisontalt.

De to formationer fra jura-nedre kridt er af samme type som de triassiske. De er kendt fra en række boringer og er stort set begrænset til Nordjylland. 
Med udvælgelsen af disse formationer var det hensigten at gøre undersøgelsen udtømmende med hensyn til mulige reservoirer, således som vi idag kender undergrundens opbygning. For de enkelte formationer fra trias, jura og nedre kridt er der dog en varierende mængde datapunkter kendt ligesom disse punkter er ulige fordelt geografisk. Den palæozoiske lagserie er kun kendt $i$ et begrænset omfang.

\section{Principper for temperaturberegning}

Undergrundens temperaturfordeling tilfredsstiller varmeledningsligningen, der på almen form kan skrives som

$$
\operatorname{div}(k \operatorname{grad} T)-\operatorname{div}\left(\varrho^{\prime} c^{\prime} \bar{v} T\right)+A=\rho c \frac{\partial T}{\partial t}
$$

Ligningen angiver sammenhængen mellem temperatur $(T)$, tiden $(t)$, hastigheden $(\bar{v})$ for materialer $i$ bevægelse og de materialefysiske parametre, massefylde $\left(\varrho, \varrho^{\prime}\right)$, varmefylde $\left(c, c^{\prime}\right)$, varmeledningsevne (k) og varmeproduktion (A). Kendes de parametre, der indgår $\mathrm{i}$ ligningen, og de nødvendige begyndelses- og randbetingelser, såsom overfladetemperaturen og den geotermiske flux (heat flow), kan temperaturen bestemmes teoretisk som en analytisk eller numerisk løsning til denne ligning. Er parametrene valgt korrekt, skal der være overensstemmelse mellem teoretisk beregnede og målte værdier.

De målte temperaturer, der foreligger fra de danske dybdeboringer er i det væsentlige Bottom Hole Temperaturer (BHT) opgivet af de selskaber, der har foretaget kulbrinteefterforskningsboringer. Det er generelt vanskeligt at vurdere nøjagtigheden af disse målinger, men hvor der er foretaget flere bestemmelser i samme dybdeniveau og til forskellig tid efter cirkulation af boremudder i boringen, kan nøjagtigheden vurderes, og en approksimativ ligevægtstemperatur (sand formationstemperatur) kan ofte bestemmes gennem teoretisk eller empirisk korrektion.

Inden for dybdeintervallet $2000-3000 \mathrm{~m}$ indicerer måleresultaterne såvel regionale som lokale variationer af størrelsesordenen \pm 10 til $\pm 30^{\circ} \mathrm{C}$. Generelt må sådanne variationer tilskrives variationer $\mathrm{i}$ undergrundens varmeledningsevne og geotermisk flux, evt. desuden varmeproduktion og grundvandsbevægelse. For at kunne vurdere disse forhold opstilles her regionale fysiske modeller for undergrunden.

Erfaringsmæssigt kan der regionalt ses bort fra materialebevægelse, tidsmæssige temperaturvaria- tioner og horisontal varmestrøm. Under disse simplificerende forudsætninger har varmeledningsligningen formen

$$
\frac{\mathrm{d}^{2} \mathrm{~T}}{\mathrm{dz}^{2}}=-\frac{\mathrm{A}}{\mathrm{k}}
$$

hvor $\mathrm{z}$ er dybden i jordmodellen. Vi skal her inddele undergrunden $\mathrm{i}$ en række horizontale lag med konstant varmeledningsevne og varmeproduktion. Temperaturen ved basis af det $\mathrm{n}^{\text {te }}$ lag kan da bestemmes via følgende analytiske løsningsudtryk:

$$
\begin{aligned}
\mathrm{T}_{\mathrm{n}}=\mathrm{T}_{\mathrm{o}} & +\sum_{\mathrm{i}=1}^{\mathrm{n}}\left[\frac{\left(\mathrm{z}_{\mathrm{i}}-\mathrm{z}_{\mathrm{i}-1}\right)}{\mathrm{k}_{\mathrm{i}}}\left(\mathrm{q}_{\mathrm{o}}-\sum_{\mathrm{j}=1}^{\mathrm{i}-1} \mathrm{~A}_{\mathrm{j}}\left(\mathrm{z}_{\mathrm{j}}-\mathrm{z}_{\mathrm{j}-1}\right)\right)\right. \\
& \left.-\frac{\mathrm{A}_{\mathrm{i}}\left(\mathrm{z}_{\mathrm{i}}-\mathrm{z}_{\mathrm{i}-1}\right)^{2}}{2 \mathrm{k}_{\mathrm{i}}}\right]
\end{aligned}
$$

hvor $\mathrm{T}_{\mathrm{o}}$ og $\mathrm{q}_{\mathrm{o}}$ er temperatur og geotermisk flux ved overfladen $(z=O), z_{i}$ dybden til basis af det $i^{\text {te }}$ lag, $k_{i}$ og $A_{i}$ varmeledningsevne og varmeproduktion $i$ det $\mathrm{i}^{\text {te }}$ lag. De vigtige parametre er således foruden overfladetemperaturen den geometriske flux samt varmeledningsevne og varmeproduktion for lagfølgen til det maksimumsniveau, hvor temperaturen ønskes beregnet. De enkelte parametre skal i det følgende vurderes.

\section{Varmeledningsevne}

Der er på DGU's kernematerialer gennemført en serie bestemmelser af varmeledningsevne (jvf. appendix 2). Middelværdien af 175 enkeltbestemmelser (værdien målt på cuttings-prøver er ikke medtaget) er $2,4 \mathrm{~W} \mathrm{~m}^{-1} \mathrm{~K}^{-1} \mathrm{og}$ standardafvigelsen $1,0 \mathrm{~W} \mathrm{~m}^{-1} \mathrm{~K}^{-1}$ (fig. 3). Ledningsevnernes nøjagtighed er varierende på grund af materialernes stærkt varierende karakter. For porøse materialer er der en betydelig forskel på ledningsevnen for tørt og vandmættet materiale. Det er derfor for tørre prøvematerialer nødvendigt at genskabe den vandmættede situation, eller hvor dette ikke er muligt, beregningsmæssigt via målt porøsitet og måling i $\mathrm{f}$. eks. alkoholmættet materiale at bestemme den ækvivalente værdi for vandmættet bjergart. Ved denne proces sker der typisk fysiske ændringer, der forringer målingernes kvalitet. Det gælder især for bjergarter, der indeholder betydelige mængder lermineraler. De nøjagtigste værdier fås generelt for sandsten og kalksten. Samtlige værdier er bestemt med "needle probe" metoden i vandmættet eller al- 


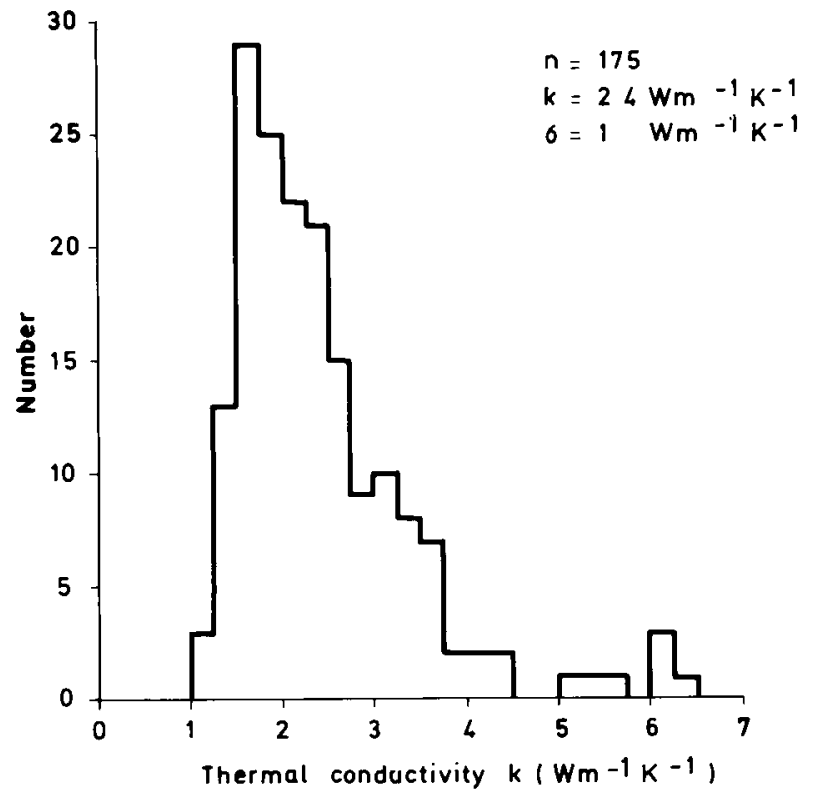

Fig. 3. Histogram over varmeledningsevne.

koholmættet materiale. Enkeltbestemmelserne skønnes at have en nøjagtighed på $\pm 10 \%$.

De laveste værdier på $1-2 \mathrm{~W} \mathrm{~m}^{-1} \mathrm{~K}^{-1}$ forekommer ved stærkt lerholdige bjergarter. Stensalt, anhydrit og dolomit har de højeste værdier på 5-7. Sandsten har typisk værdier på 2,5-4 og kalksten $1,5-2,5 \mathrm{~W} \mathrm{~m}^{-1}$ $\mathrm{K}^{-1}$.

Variation med dybde og lithologi fremgår af appendix 2, fig. 17-21. For bjergarter med samme mineralsammensætning er ledningsevnen stærkt porøsitetsafhængig, således at ledningsevnen aftager med stigende porøsitet. Der er gennemført enkelte målinger af temperatureffekten på ledningsevnen. Disse resultater samt værdier hentet fra litteraturen viser, at denne effekt for de aktuelle bjergarter typisk er forholdsvis lille sammenlignet med den nøjagtighed, hvormed ledningsevnen er kendt i de større dybder, hvor effekten måtte være signifikant.

Baseret på de omtalte målinger samt foreløbige værdier fra den detaljerede termiske undersøgelse af ledningsevne og temperaturgradienter i Aars 1a er der for lagfølgen fra havniveau til basis af trias (jvf. tabel 1) opstillet de i tabel 2 viste ledningsevnemodeller.

Der er tale om middel vertikal ledningsevne for de enkelte lag. De foretrukne værdier anvendes i model A, og model B og C indeholder værdier, der skønnes at være nær henholdsvis maximum og minimum.
Tabel 1. Definition af laggrcenser anvendt vedr. varmeledningsevneinddeling (jvf. tabel 2)

Lag Tidsafsnit (d: dybde under havniveau)

$\begin{array}{ll}1 & \text { Havniveau til top danien } \\ 2 & \text { Danien og øvre kridt } \mathrm{d}<500 \mathrm{~m} \\ 3 & \text { Danien og øvre kridt; } 500 \mathrm{~m}<\mathrm{d}<1000 \mathrm{~m} \\ 4 & \text { Øvre kridt; d }>1000 \mathrm{~m} \\ 5 & \text { Nedre kridt, øvre jura og mellem jura } \\ 6 & \text { Nedre jura } \\ 7 & \text { Trias }\end{array}$

Tabel 2. Varmeledningsevne - fordeling (vardier $i \mathrm{Wm}^{-1} \mathrm{~K}^{-1}$ )

\begin{tabular}{cccc} 
Lag & Model A & Model B & Model C \\
\hline 1 & 2,0 & 2,5 & 1,5 \\
2 & 1,7 & 1,8 & 1,6 \\
3 & 2,1 & 2,3 & 2,0 \\
4 & 2,7 & 2,9 & 2,5 \\
5 & 2,0 & 2,4 & 1,8 \\
6 & 1,5 & 1,8 & 1,3 \\
7 & 3,0 & 3,5 & 2,5
\end{tabular}

\section{Varmeproduktion}

Varmeproduktion i de geologiske materialer er bestemt af koncentrationen af $\mathrm{U}$, Th og $\mathrm{K}$, hvis radioaktive isotoper gennem henfald giver anledning til produktion af varme. $\mathrm{U}$, Th og $\mathrm{K}$ koncentrationen for 28 sedimentprøver er bestemt af Risø med gammaspektrometrimetoden. Baseret på disse målinger er varmeproduktionen beregnet (jvf. appendix 2). Der er anvendt målte eller skønnede massefyldeværdier samt standardværdier for isotopsammensætning og varmeafgivelse. Standardafvigelse svarer til ca. \pm $0,05 \mu \mathrm{W} \mathrm{m} \mathrm{m}^{-3}$ på enkeltmålingerne. Middelværdien af bestemmelserne er $1,1 \mu \mathrm{W} \mathrm{m}{ }^{-3}$ med standardafvigelsen 0,7 (jvf. fig. 4 ).

I de teoretiske beregninger anvendes værdien 1 $\mu \mathrm{W} \mathrm{m}{ }^{-3}$ konstant for alle lag. For dybdeintervallet 0-3000 m er modeleffekten $0-2^{\circ} \mathrm{C}$ og for intervallet $3000-7000 \mathrm{~m} 1-10^{\circ} \mathrm{C}$. På grundlag heraf vurderes sedimenternes varmeproduktion at være så lav, at dens indflydelse på temperaturfordelingen for den aktuelle problemstilling generelt er negligerbar.

\section{Den geotermiske flux}

Der er hidtil i det danske område kun gennemført foreløbige direkte bestemmelser af den geotermiske flux. Disse bestemmelser er foretaget i overfladenære formationer. For større dybder foreligger 6 skønnede 


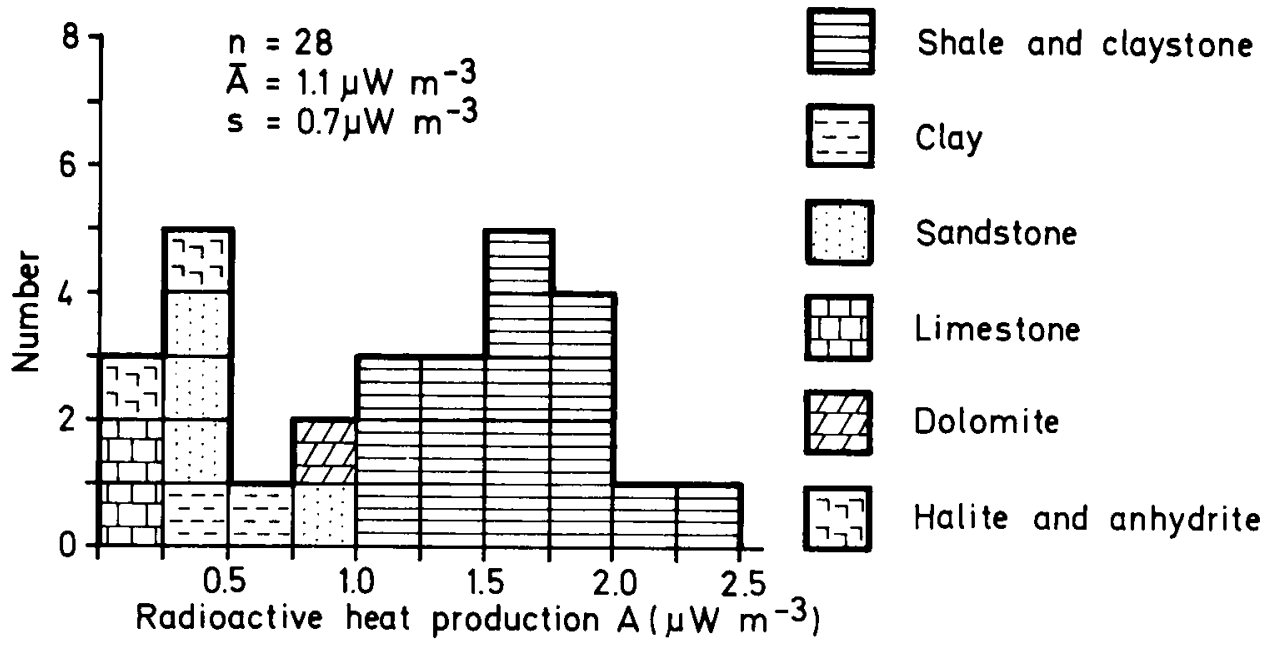

Fig. 4. Histogram over varmeproduktion.

værdier, hvoraf de 5 er fra lokaliteter i det nordlige Jylland (fig. 5). På grundlag heraf samt baseret på variationer kendt fra naboområder eller områder med tilsvarende geologisk opbygning som den danske, skønnes fluxen generelt at ligge inden for intervallet $50-80 \mathrm{~mW} \mathrm{~m}^{-2}$.

For Storbritanien, der er godt undersøgt (Richardson og Oxburgh 1979), er middelværdien ca. $60 \mathrm{~mW}$ $\mathrm{m}^{-2}$. Variationer mellem $40 \mathrm{og} 70 \mathrm{~mW} \mathrm{~m}^{-2}$ forekommer for store områder. Den lavest observerede værdi er 25 og den højeste $130 \mathrm{~mW} \mathrm{~m}^{-2}$. Høj varmeflux er fundet over områder med granitiske intrusivlegemer, der er beriget med U, Th og K. Mange sådanne strukturer er kendt fra blotninger i det sydskandinaviske grundfjeld og må forventes at forekomme under sedimenterne i det danske område. Kendskabet til placeringen af sådanne strukturer foreligger ikke, og de hidtidige varmefluxbestemmelser muliggør ikke opstilling af modeller med geografiske variationer. Derfor regnes med konstante modelværdier for hele landet. I model A anvendes $60 \mathrm{og}$ i model B og C henholdsvis $50 \mathrm{og} 80 \mathrm{~mW} \mathrm{~m}^{-2}$.

\section{Overfladetemperatur}

Middeltemperaturen i jordoverfladen afviger yderst sjældent fra $7-9^{\circ} \mathrm{C}$. Fra terrænoverfladen til havniveau, der er udgangsniveau for modelberegningerne, vil temperaturen med den danske topografi typisk stige $1-3^{\circ} \mathrm{C}$. Modeltemperaturen for havniveau er regnet konstant $10^{\circ} \mathrm{C}$.

\section{Temperatur og temperaturgradienter}

Temperaturberegningerne foretages på grundlag af de ovenfor omtalte tre modeller. Model A indeholder de foretrukne parametre, i model B kombineres høj varmeledningsevne og lav varmeflux, og i model $\mathrm{C}$ lav varmeledningsevne og høj varmeflux. Da varmeproduktionen er meget lille, vil de enkelte lag i modellen have næsten konstante geotermiske gradienter bestemt via $\Delta T / \Delta z=q_{o} / k$. Værdier for disse gradienter fremgår af tabel 3.

De teoretiske modeltemperaturer sammenholdes med målte BHT-værdier i fig. 6 for fire områder: 1) Centrale dele af Det danske Subbassin, 2) Området syd for Ringkøbing-Fyn Højderyggen, 3) Sjælland og, 4) Ringkøbing-Fyn Højderyggen samt det nordligste Jylland med højtliggende grundfjeld. For de fire områder er der valgt typiske lagfølger til temperaturdybde beregningen.

Tabel 3. Geotermiske gradienter (vardier i $m K m^{-1}={ }^{\circ} \mathrm{C} \mathrm{km}^{-1}$ )

\begin{tabular}{cccc} 
Lag & Model A & Model B & Model C \\
\hline 1 & 30 & 20 & 53 \\
2 & 35 & 28 & 50 \\
3 & 29 & 23 & 40 \\
4 & 22 & 17 & 32 \\
5 & 30 & 21 & 44 \\
6 & 40 & 28 & 62 \\
7 & 20 & 14 & 32
\end{tabular}

På grundlag heraf vurderes model $\mathrm{A}$ at give det bedste grundlag for en regional vurdering af reservoirtemperaturerne. Model B og C er konstrueret, så de skulle give hvad der antages at være nær de henholdsvis laveste og højeste temperaturer, der kan op- 


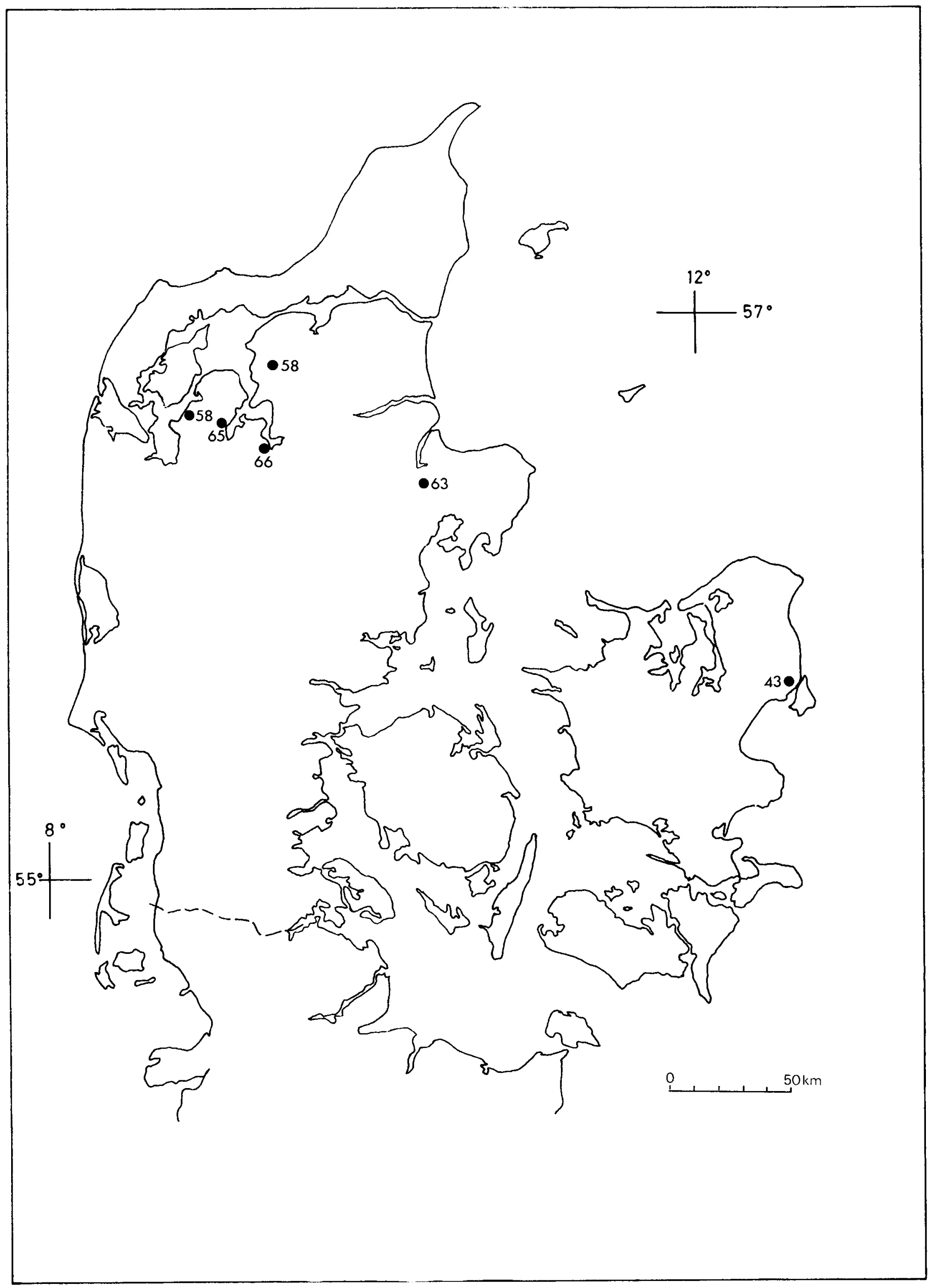

Fig. 5. Skøn over den geotermiske flux $\left(\mathrm{mW} \mathrm{m}^{-2}\right)$. Værdierne angives uden klimatisk korrektion (Balling 1979). 

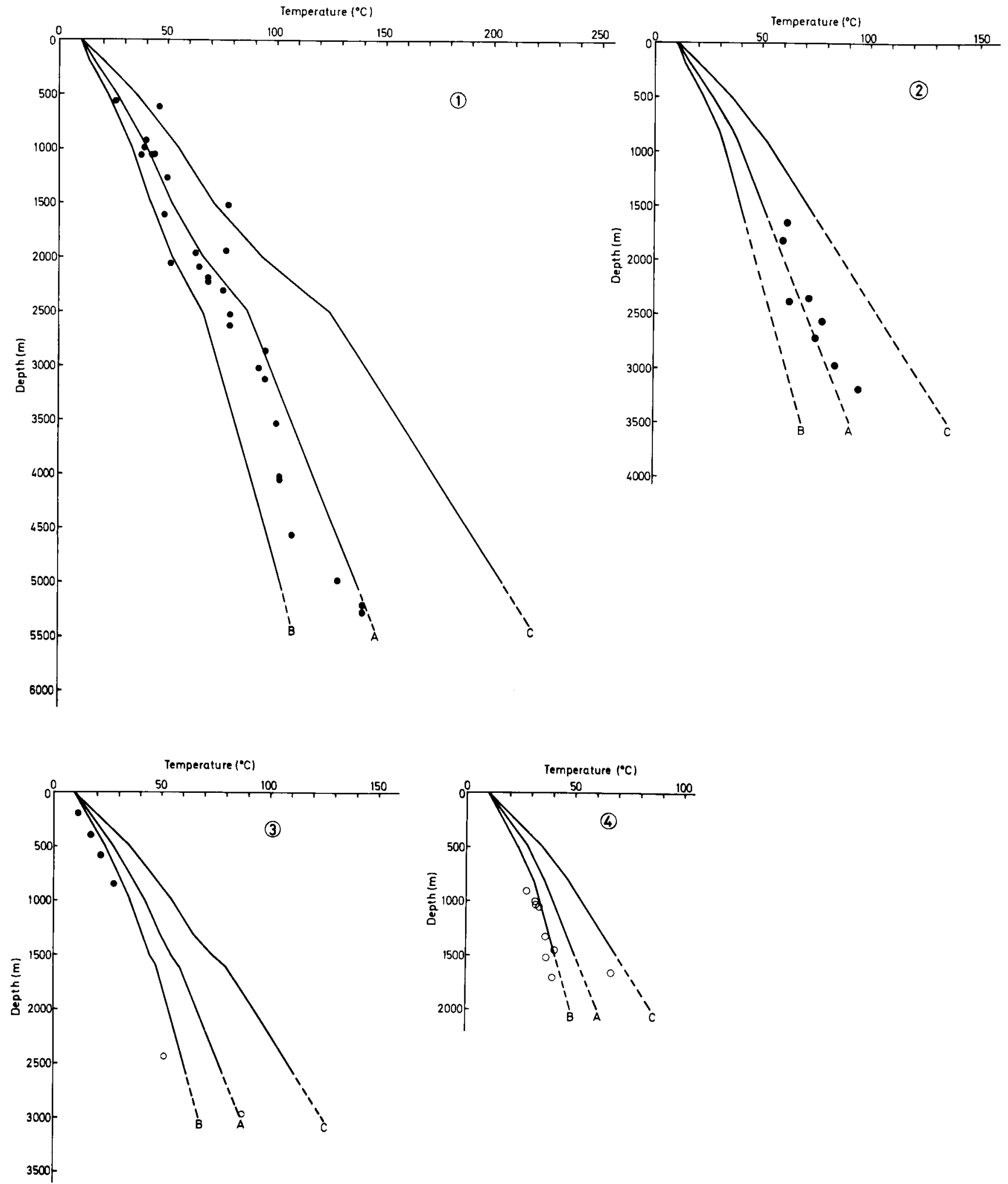

Fig. 6. Typiske modeltemperaturer i relation til BHT-værdier for centrale dele af Det danske Subbassin (1), områder syd for Ringkøbing-Fyn Højderyggen (2), Sjælland (3) og områder over Ringkøbing-Fyn Højderyggen og det nordligste Jylland (4). Korrigerede BHT- eller ligevægtsværdier er angivet ved punkter og ukorrigerede værdier ved cirkler. (Ukorrigerede værdier er medtaget for områder uden eller med få korrigerede værdier). 

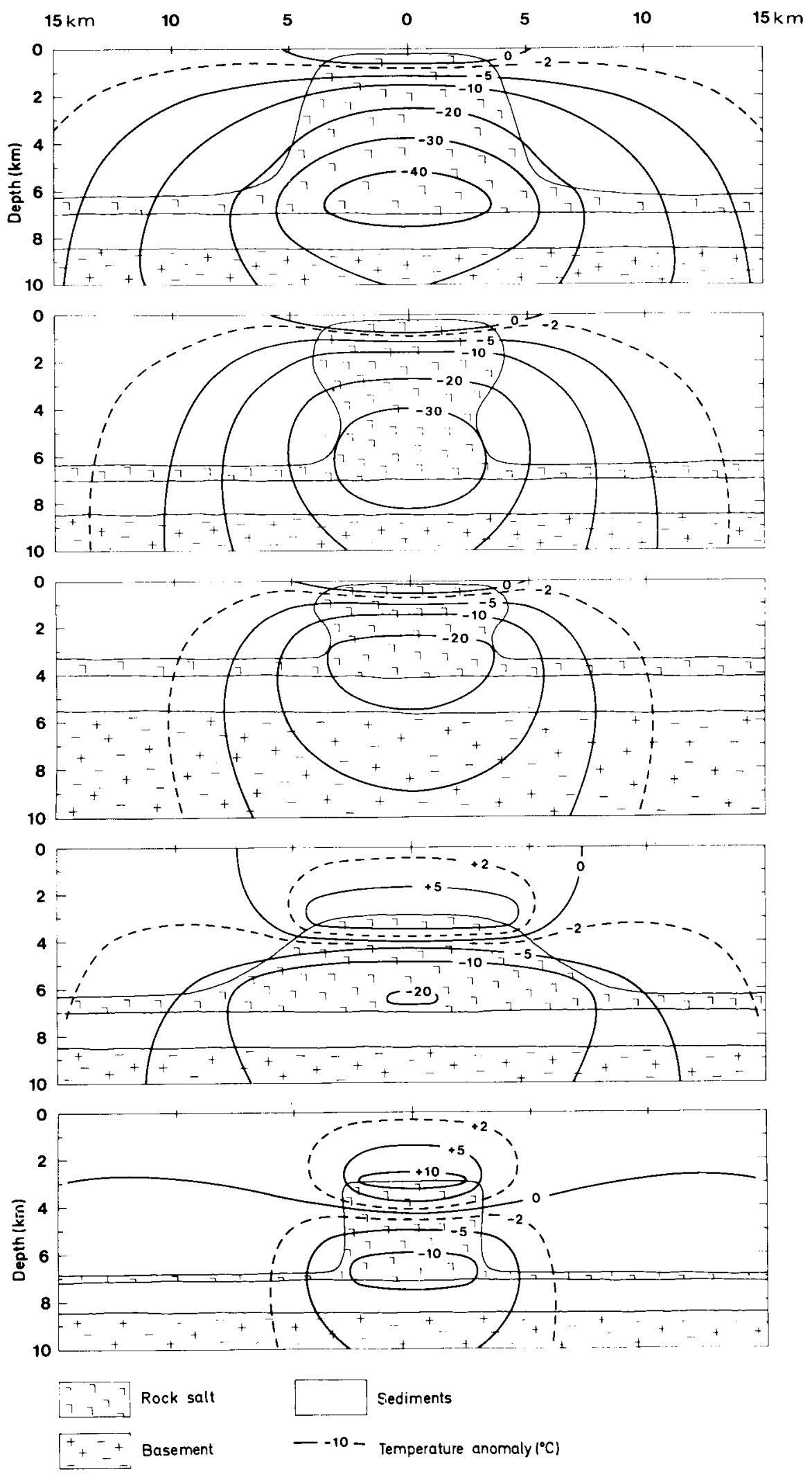

Fig. 7. Temperaturmodelanomalier beregnet for saltstrukturer af varierende form (cf. Balling 1978). 
nås, hvilket er $i$ god overensstemmelse med måleresultaterne. Sandsynligheden for at opnå temperaturer nær model B-værdierne synes generelt højere end sandsynligheden for at opnå værdier nær model Cværdierne. Man må dog antage, at selv de korrigerede BHT-værdier ofte vil angive minimumsværdier.

Der er ikke i modellerne taget hensyn til temperatureffekten fra klimatiske variationer, der sandsynligvis vil reducere modeltemperaturerne med typisk $3-5^{\circ} \mathrm{C}$ inden for dybdeintervallet $500-1500 \mathrm{~m}$.

Ved temperaturberegningerne er landet inddelt $i$ et net med sidelængde $10^{\prime}$ (øst-vest) $\times 6^{\prime}$ (nord-syd) for området syd for $56^{\circ} \mathrm{N}$ og øst for $10^{\circ} \emptyset$. I den øvrige del af landet dvs. det nordvestligste Jylland er sidelængden halveret $\left(5^{\prime} \times 3^{\prime}\right)$, idet der her over korte afstande forekommer større dybdevariationer. For hvert netpunkt er dybden til basis af de aktuelle lag bestemt fra de geologiske kort, og temperaturen er beregnet via ligning (3). Der er fremstillet model A, B og C isotermkort for basis af øvre kridt kalksten (fig. 38-40), basis af Haldager Sand (fig. 31-33) og for nær top trias (fig. 24-26). Desuden er der fremstillet model A isotermkort for approximativ basis trias (fig. 15) samt for dybderne $2000 \mathrm{og} 3000 \mathrm{~m}$ (fig. 42 og 44).

Modelnøjagtigheden for isotermerne afhænger af den dybdemæssige nøjagtighed, hvormed de geologiske laggrænser er bestemt. En nøjagtighed på $\pm 200-300 \mathrm{~m}$ svarer typisk i model A til $\pm 5-10^{\circ} \mathrm{C}$, i model B til ca. $\pm 5^{\circ} \mathrm{C}$ og i model C til $\pm 10-15^{\circ} \mathrm{C}$.

De stiplede kurver på isotermkortene angiver områder med saltstrukturer, hvor modelforudsætningerne vides ikke at være opfyldt. Kurveforløbet angiver det approximative niveau, som isotermerne ville følge, dersom saltlegemet ikke var til stede. Størrelsen af de temperaturanomalier, som strukturerne forårsager, afhænger af deres form, størrelse og dybdemæssige placering (jvf. fig. 7). Vurderingen af temperaturen under beskrivelsen af de enkelte reservoirformationer er primært foretaget på grundlag af model A. Model B og C indeholder værdier, der kan forekomme for både begrænsede områder og større områder, hvor måleinformationen er meget ringe f.eks. Sjælland, men som på det foreliggende grundlag ikke anvendes til en regional vurdering.

\section{Vurdering af porøsitet, permeabilitet og net sand tykkelse}

Porøsitets- og permeabilitetsvardier (se appendix 1 og fig. 8) er baseret på kontinuerte petrofysiske borehulsmålinger og kerneanalyser.

Porøsitetsværdier baseret på petrofysiske målinger er beregnet ud fra følgende logs:

Formation Density Log

FDC

Neutron Log, Compensated

$\mathrm{CNL}$

Sonic Log, Interval Transit Time ITT

Spontaneous-Potential Log

Resistivity Log

Hver log er så vidt muligt vurderet, kalibreret og korrigeret for borehullets diameter, boremudderets sammensætning, temperaturvariation og lithologi.

Petrofysiske målemetoder har undergået en rivende udvikling inden for de sidste ti til femten år, ligesom kvaliteten af de petrofysiske målinger er forbedret væsentligt. Dette medfører, at målinger fra før 1965-70 er af mindre god kvalitet. Datamængden fra gamle boringer er stærkt begrænset og muligheden for at foretage korrektioner er ringe.

For hver boring er reservoirlagene identificeret på logs. Log'en er inddelt $i$ afsnit af mægtighed 0,5-5 meter med ensartede petrofysiske værdier.

Log-udslagene er aflæst, korrigeret og brugt til porøsitetsberegning. Porøsiteten af et reservoirlag, således som det fremgår af nærværende rapport, er vægtede gennemsnit af porøsitetsværdier for lagets enkelte delafsnit. Det totale, vægtede gennemsnit af reservoirlag indenfor en formation samt reservoirlagenes samlede tykkelse fremgår af appendix $1 \mathrm{og}$ kortene, fig. 12, 13, 18, 19, 21, 22, 28, 29, 35 og 36 .

Størst sikkerhed i porøsitetsberegningen fremkommer såfremt det er muligt at plotte densitetsmåling (FDC) mod porøsitetsmåling (CNL). Såfremt dette ikke er muligt kan densitets- og porøsitetsmålingen bruges alene til en udmærket porøsitetsberegning.

Sonic log'en (ITT) registrerer, hvor hurtigt et lydsignal forplantes igennem en given bjergart. Lydhastigheden kan under visse forhold ligeledes anvendes til porøsitetsberegning, men beregningen er behæftet med nogen usikkerhed.

Boringer fra før 1955 har ingen af ovennævnte logs. Da en stor del af boringerne er fra før 1955, er det fundet påkrævet at vurdere porøsitetsforholdene 
i disse boringer ved brug af Spontaneous-Potential Log (SP) og Resistivity Log målinger. Det er på den måde muligt at beregne porøsiteten ved hjælp af empiriske formler. Denne indirekte beregningsmetode er afhængig af adskillige variable faktorer, der ofte er dårligt kendt på grund af mangelfuld rapportering fra disse gamle boringer. Hvor det er muligt er porøsitetsberegninger foretaget ved denne metode, men de anførte værdier skal tages med stort forbehold. Ved kontrol i boringer, hvor porøsitetsberegning fra andre logs eller kerneanalyser foreligger, viser det sig at Spontaneous-Potential og Resistivity porøsitetsberegningerne er for høje.

Kerner fra reservoirformationer er beskrevet lithologisk og analyseret efter nedennævnte standardiserede normer.

Den lithologiske kernebeskrivelse omfatter en generel beskrivelse af kernens bjergarter, bestemmelse af grovkornede aflejringers sortering og afrunding, angivelse af farve og mineralindhold samt vurdering af bjergartens aflejringsmiljø.

Efter kernebeskrivelsen er kernen korreleret med de lithologiske fortolkninger fra de petrofysiske målinger for at fastslå dens nøjagtige placering i reservoiret.

Detaljerede kerneanalyser omfattende måling af porøsitet og luftpermeabilitet samt analyse af bjergarternes textur og struktur er udført på udborede cylinderprøver, plugs, fra udvalgte niveauer af kernen.

Med henblik på bestemmelse af porøsitet og permeabilitet er horisontale og vertikale plugs udboret af kernen for hver $30-40 \mathrm{~cm}$ i de udvalgte niveauer. Disse cylinderprøver er $2-3 \mathrm{~cm}$ lange og med diameter $1,9 \mathrm{~cm}$ eller $2,5 \mathrm{~cm}$.

Plug'en er beskrevet under mikroskop med henblik på bestemmelse af parametre, der influerer på porøsitet og permeabilitet. De vigtigste parametre er kornstørrelse, sorterings- og hærdningsgrad.

Porøsiteten er uafhængig af kornstørrelsen, men stærkt afhængig af variationen i kornstørrelse, dvs. sorteringsgraden. Stor variation og dermed dårlig sortering formindsker porøsiteten, fordi små korn udfylder hulrummene mellem de større.

Den effektive porøsitet (porøsiteten af forbundne porer) samt porernes absolutte størrelse spiller en rolle for permeabiliteten. Som hovedregel gælder, at jo mindre kornstørrelse og jo dårligere sortering, des mindre porestørrelse og dermed ringere permeabilitet. Selv et lille lerindhold $i$ et sediment vil nedsætte permeabiliteten og dermed reservoirets produktivitet.

Hærdning forårsaget af cementering og udkrystallisation af mineraler i porerne nedsætter både porø- sitet og permeabilitet. Porøsiteten aftager tillige med reservoirets dybde $\mathrm{i}$ bassinet, idet belastningen af overliggende bjergarter forårsager en sammenpresning af aflejringen. Dette forhold er eksemplificeret under beskrivelsen af de enkelte reservoirformationer (se f.eks. fig. 11).

Udvalgte prøver er blevet beskrevet petrografisk og mineralogisk ved hjælp af petrografmikroskopi (tyndslib) og røntgendiffraktometri for at undersøge og vurdere graderne af kompaktion og hærdning.

Porøsitets- og luftpermeabilitetsbestemmelser er foretaget på plug-prøverne i DGU's laboratorium.

Porøsitet er bestemt på to måder, enten ved at indeslutte prøven i et trykkammer under skiftende trykforhold eller ved, under højt tryk, at fylde bjergartens porer med kviksølv og måle det indsprøjtede volumen. Begge metoder giver et mål for effektiv porøsitet.

Førstnævnte metode, Boyle's Lov metoden, giver en porøsitetsbestemmelse med usikkerhed på mindre end $\pm 1 \%$, medens porøsitetsbestemmelse ved kviksølvinjektion generelt giver pessimistiske værdier, der tillige er behæftet med en større usikkerhed end $\pm 1 \%$. Boyle's Lov metoden er derfor anvendt til rutineanalyser.

I nærværende arbejde er permeabiliteten bestemt som luftpermeabilitet ud fra det relative tryk, der er nødvendig for at presse et givet volumen af luftarten kvælstof igennem prøven. Permeabilitetsmålingerne er reproducerbare indenfor $\pm 10 \%$.

Vurderingen og præsentationen af porøsitets- og permeabilitetsanalyserne for et reservoir er foretaget dels ved tabellering og dels ved grafisk fremstilling. Rutinemæssigt er afbildet porøsitet mod permeabilitet (fig. 8), og porøsitet eller permeabilitet mod sorteringsgrad, kornstørrelse og dybde. I denne rapport er porøsitet afbildet mod dybde (se fig. 11, 20, $27 \mathrm{og}$ 34).

\section{Porøsitets- og permeabilitetsværdier}

Porøsitets- og permeabilitetsværdier for hvert enkelt reservoir er tabuleret $\mathrm{i}$ appendix $1 \mathrm{og}$ angivet på fig. $11,12,13,18,19,20,21,22,27,28,29,34,35,36$ og tavle 1-8.

For hver porøsitet er angivet hvilken logtype, der ligger til grund for beregningen, ligesom kerneanalyser er markeret.

Logporøsiteter er vægtede gennemsnit af punktvis beregnede porøsiteter. Porøsiteter og permeabiliteter fra kerneanalyser er vurderede middelværdier, da det indenfor de afstukne tidsrammer kun i be- 


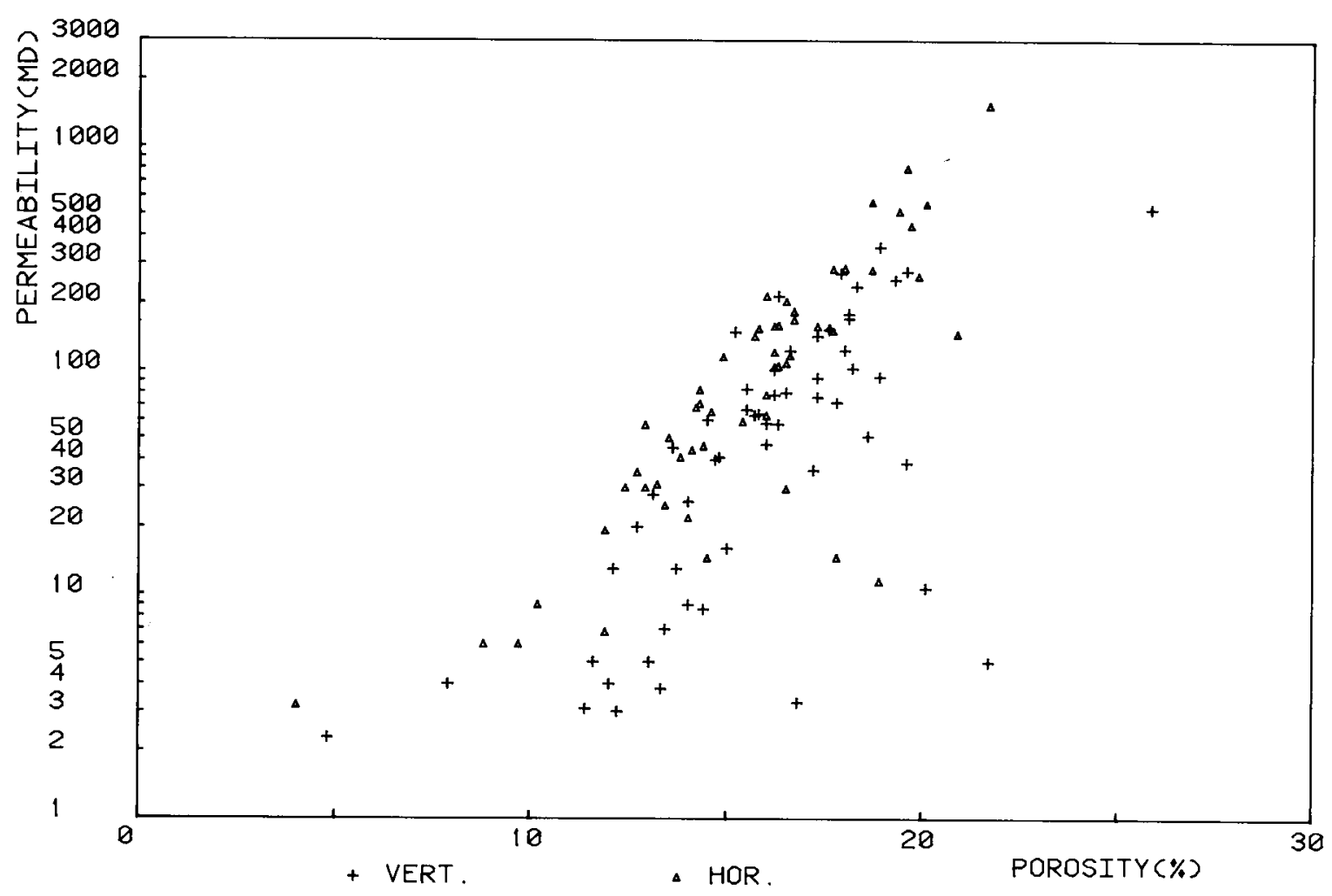

Fig. 8. Diagrammet illustrerer et generelt forhold mellem porøsitet og permeablitet. Det ses, at permeabiliteten aftager med porøsiteten, og at permeabiliteten målt horisontalt generelt er højere end målt vertikalt. Både en direkte afhængighed mellem de to parametre og afvigelsen fra denne benyttes til at karakterisere og vurdere reservoiret.

grænset omfang har været muligt at foretage en detaljeret kerneanalyse med gennemgang af porøsitetsog permeabilitetsafhængighed af lithologi, kornstørrelsesfordeling samt sorterings- og hærdningsgrad. Dette medfører, at de tabulerede værdier fra kerneanalyser ikke er vægtede gennemsnitsværdier for reservoirlag baseret på vægtede gennemsnitsværdier for kernede intervaller i reservoiret, men at der ud fra analyserne er vurderet en repræsentativ gennemsnitsværdi. I vurderingen er der set bort fra maksimums- og minimumsværdier.

\section{Net Sand}

Net sand tykkelsen angiver en samlet tykkelse af reservoiret, dvs. samlet tykkelse af sandlagene i den undersøgte formation eller member. Tykkelsen er baseret på tolkning af petrofysiske logs. Net sand tykkelsen kan ikke umiddelbart anvendes i reservoirvurderingen, idet en tykkelsesangivelse kan være baseret på f.eks. tre ret ensartede sandlag, der er velegnede til produktion, eller være baseret på f.eks. femten tynde heterogene lag hvorfra en pumpning er vanskelig.
Inddelingen i lithostratigrafiske enheder, angivelse af dybde under havniveau og tykkelse er baseret på interne rapporter og publicerede data.

\section{Midt dybde}

Midt dybde værdien er benyttet til grafisk afbildning af porøsitetens afhængighed af dybden. En mere korrekt dybdeangivelse ville være midt dybde af reservoirlag; denne værdi er ikke anvendt i de foretagne beregninger af tidsmæssige årsager.

Reservoirvurderingen kan foretages med væsentlig større sikkerhed og større nøjagtighed, såfremt luftpermeabilitetsmålingerne får større reproducerbarhed og suppleres med måling af væskepermeabilitet ved anvendelse af simuleret formationsvand. Yderligere optimering af vurderingsgrundlaget fremkommer såfremt en hurtig og mere effektiv databehandling og grafisk præsentation af data bliver muliggjort samtidig med, at den nødvendige geologiske/petrofysiske fortolkning er tilstede. For at kunne foretage en eksakt vurdering af et reservoirs ydeevne er det 
dog nødvendigt med en langvarig prøvepumpning direkte i borehullet.

Vurdering af reservoirlagenes kompaktion, hærdning og cementering samt eventuel sekundær opløsning og opspræakning er vigtige faktorer ved vurderingen af et reservoirs ydeeevne. Disse diagenetiske processer kan kun klarlægges efter langvarig præparation af bjergartsprøver, og selve analysearbejdet er også tidskrævende. Derfor er kun enkelte analyser gennemført, og det må forudses, at en detaljeret undersøgelse af potentielle områder må indbefatte et sådant analysearbejde.

Som anført under porøsitetsbestemmelse på basis af petrofysiske målemetoder er et større antal porøsitetsværdier udregnet ved brug af Spontaneous-Potential Log og Resistivity Log målinger. Usikkerheden på de beregnede porøsitetsværdier vil kunne nedbringes væsentligt, såfremt det bliver muligt at gennemføre en tilbundsgående analyse af de petrofysiske logs indbyrdes relationer. I regioner med moderne målinger vil der kunne opstilles relationer mellem Neutron - Density porøsitet og Spontaneous-Potential - Resistivity porøsitet. De dermed fundne relationer vil muliggøre en mere nøjagtig porøsitetsbestemmelse i de talrige ældre boringer, der i nærværende arbejde danner en stor del af grundlaget ved vurderingen af de geotermiske muligheder.

\section{Dybdekortlægning}

Som udgangspunkt for en vurdering af dybde og udbredelse af potentielle geotermiske reservoirer er der på grundlag af reflektionsseismiske data udført en række regionale isochron kort (tidskort) af markante og kontinuerte seismiske reflektorer, der har interesse i geotermisk sammenhæng. Kortlægningen omfatter 4-5 reflektioner fra det centrale og nordlige Jylland, Sydjylland, samt hovedparten af Sjælland. (Et eksempel er gengivet i tavle 9 og $10 \mathrm{i}$ form af tidskort for top trias, Gassum Formationen). I disse områder findes en rimelig dækning af seismiske data af varierende kvalitet. Disse omfatter både ældre analog optagne single-fold linier, og moderne processerede multi-fold sektioner. I alt er der til grundlag for denne rapport interpreteret ca. $9000 \mathrm{~km}$ seismik fordelt på ca. 450 linier. De interpreterede reflektorer er korreleret til lithostratigrafiske grænser ved hjælp af well velocity surveys. De regionale tidskort (skala 1:500.000) er normalt kontureret med et kurveinterval på 0,05 sek., medens de dybere niveaure er kontureret med et kurveinterval på 0,1 el- ler 0,25 sek. Kurveintervallet er et udtryk for den strukturelle kompleksitet og tidskortenes pålidelighed.

De ovenfor omtalte regionale tidskort har dannet grundlag for fremstilling af følgende generaliserede dybdekort: "Base Upper Cretaceous Limestone" (fig. 37), "Base Haldager Sand" (fig. 30), "Near Top Triassic" (fig. 23) og "Near Top Bunter Sandstone Formation" (fig. 14).

Dybdekonverteringen af tidskort er foretaget efter den simplest mulige metode, idet der er opstillet regionale hastighedsfunktioner for hver af de ovenfor nævnte horisonter udfra sammenhørende værdier af two-way time og dybde for de boringer hvor der eksisterer well velocity surveys. Selvstændige hastighedsfunktioner er derefter opstillet for de enkelte landsdele. For Sjællands vedkommende har det dog været nødvendigt at støtte sig til "stacking" hastigheder på grund af manglende borehulskontrol. Afvigelsen fra de opstillede hastighedsfunktioner til datasættene fra boringerne har i enkelte tilfælde været op til $250 \mathrm{~m}$, hvorfor det har været nødvendigt med lokale korrektioner. Ved dybdekonverteringen er der ikke foretaget migration af tidskortene, dvs. den nødvendige korrektion for laghældninger.

I områder med manglende seismiske data, eller hvor der ikke er foretaget systematisk kortlægning, er dybdekonturerne udtegnet med støtte i de spredte boredata og med kontrol af udvalgte seismiske sektioner. I disse områder er konturerne markeret som usikre eller hypotetiske.

Det skal fastslås, at de generaliserede dybdekort kun er tænkt som oversigtskort og derfor ikke bør anvendes som beslutningsgrundlag for lokalisering af nye geotermiske undersøgelsesboringer eller opstilling af detaljerede boreprognoser. Hertil er den anvendte dybdekonverteringsmetode for grov, idet der ikke er sket optimalt brug af de seismiske hastighedsinformationer.

Forud for en fremstilling af optimale dybdekort udfra migrerede tidskort, vil det være nødvendigt at udføre en egentlig kortlægning af hastighedsfunktioner til en given reflektion. Dette inkluderer også brug af korrigerede hastighedsdata fra processeringen af feltdata. Seismiske hastigheder kan variere betragteligt selv inden for små afstande.

En sådan hastighedskortlægning er en meget tidsrøvende proces, som det ikke har været muligt at udføre regionalt indenfor rammerne af nærværende projekt.

Udover de strukturelle informationer kan det i om- 
råder med borehulskontrol og moderne multi-fold seismik undertiden være muligt at lokalisere både top og bund af et potentielt reservoir, ligesom det eventuelt kan lade sig gøre at komme med meget generelle udsagn om den laterale variation i reservoirets parametre.

Egentlige kvantitative skøn over net sand tykkelse og porøsitet og porevæske sammensætning er ikke muligt med de eksisterende seismiske data.

Hertil kræves de mest moderne typer procesșering, herunder at bringe de seismiske impulser på symmetrisk form (wavelet processering) samt i stor udstrækning modelberegninger.

\section{Beskrivelse af reservoirformationer}

Hver enkelt af de udvalgte formationer er beskrevet med hensyn til lithostratigrafi, geologisk alder, lithologi, geometri, dybde, porøsitet, permeabilitet og temperatur. Bortset fra lithologi, der baserer sig på beskrivelse af eksisterende borekerner, er de andre reservoirparametre beskrevet i foranstående kapitler.

Af de i litteraturen formelt etablerede formationer, der kan betragtes som potentielle reservoirer for indvinding af geotermisk energi, behandles Skagerrak Formationen ikke særskilt i nedenstående oversigt. Den er en bassinmarginal dannelse, der er ævivalent med de øvrige trassiske formationer (bortset fra Gassum Formationen). Bassincentralt danner den overgang til de grovkornede (sandede) formationer og udgør længst mod nørdøst basis for Gassum Formationen. I nedenstående beskrivelser er Skagerrak Formationen derfor på de enkelte lokaliteter henregnet til den relevante formation, og dens data indgår dermed i den pågældende formation (se f. eks. appendix 1).

Ledsagende de enkelte formationsbeskrivelser findes kort, der viser bl.a. tykkelse af formationerne således som denne kan aflæses på borehulslogs, dvs. at der ikke er taget hensyn til laghældninger. Seismiske data er ikke benyttet ved fremstillingen af disse kort. Isopachkurverne må betragtes som visende den relative regionale variation, medens deres lokale værdier er behæftet med stor usikkerhed.

Fremstillingen af dybdekort og temperaturkort er beskrevet i særlige afsnit ovenfor.

Alle dybdeangivelser refererer til havniveau.

\section{Palæozoikum}

Af de nedenfor beskrevne og på kortet (fig. 9) angivne aflejringer er en del bestemt til en periode i palæozoikum. Desuden er medtaget lagserier af palæozoisk alder men uden nærmere specifikation, samt lag af formodet palæozoisk alder.

På kortet fig. 9, er aflejringer uden aldersbestemmelse betegnet med selvstændige signaturer, mens angivelsen af nedre perm er en formodet alder. Nedre perm i Ringe 1 og Rødby 2 inkluderer iøvrigt her en nedre enhed af arkose og konglomerater.

Vulkanske bjergarter er mere udbredte end det fremgår af kortet, fig. 9, f.eks. i Nøvling 1 og Rønde 1 består den silure aflejring af vekslende vulkaniter og lersten.

\section{Kambrisk kvartsitisk sandsten}

Fig. 9. Appendix 1.

Lithostratigrafisk inddeling: Antagelig ækvivalent til den bornholmske Balka Kvartsit.

Geologisk alder: Nedre kambrium eller eokambrium.

Lithologi: Lys grå kvartsitisk sandsten.

Udbredelse, tykkelse og dybde: Der er kun fundet 6 $\mathrm{m}$ af den kambriske kvartsitiske sandsten i boringen Slagelse 1, men den er antagelig udbredt over større dele af Det danske Subbassin.

Dybden til top af den kvartsitiske sandsten er 2928 $\mathrm{m}$.

Porøsitet og permeabilitet: Porøsiteten i den kvartsitiske sandsten er $4 \%$ og permeabiliteten er $3 \mathrm{mD}$.

Temperatur: I Slagelse 1 antyder såvel beregnede værdier som en målt BHT-værdi en temperatur på ca. $90^{\circ} \mathrm{C}$. For Sjælland i øvrigt er kendskabet til temperaturforholdene meget ringe.

Sammenfattende bemarkninger: Kambriske kvartsitiske sandsten er kun fundet $i$ en boring og er ikke gennemboret. De skønnes ikke at være egnede geotermiske reservoirer.

\section{Karbon kalksten}

Fig. 9. Appendix 1.

\section{Lithostratigrafisk inddeling: Ingen.}

Geologisk alder: Nedre karbon; viséen.

Lithologi: Kalksten, mergelsten og lersten med underordnede siltede/sandede indslag. Kalksten, 


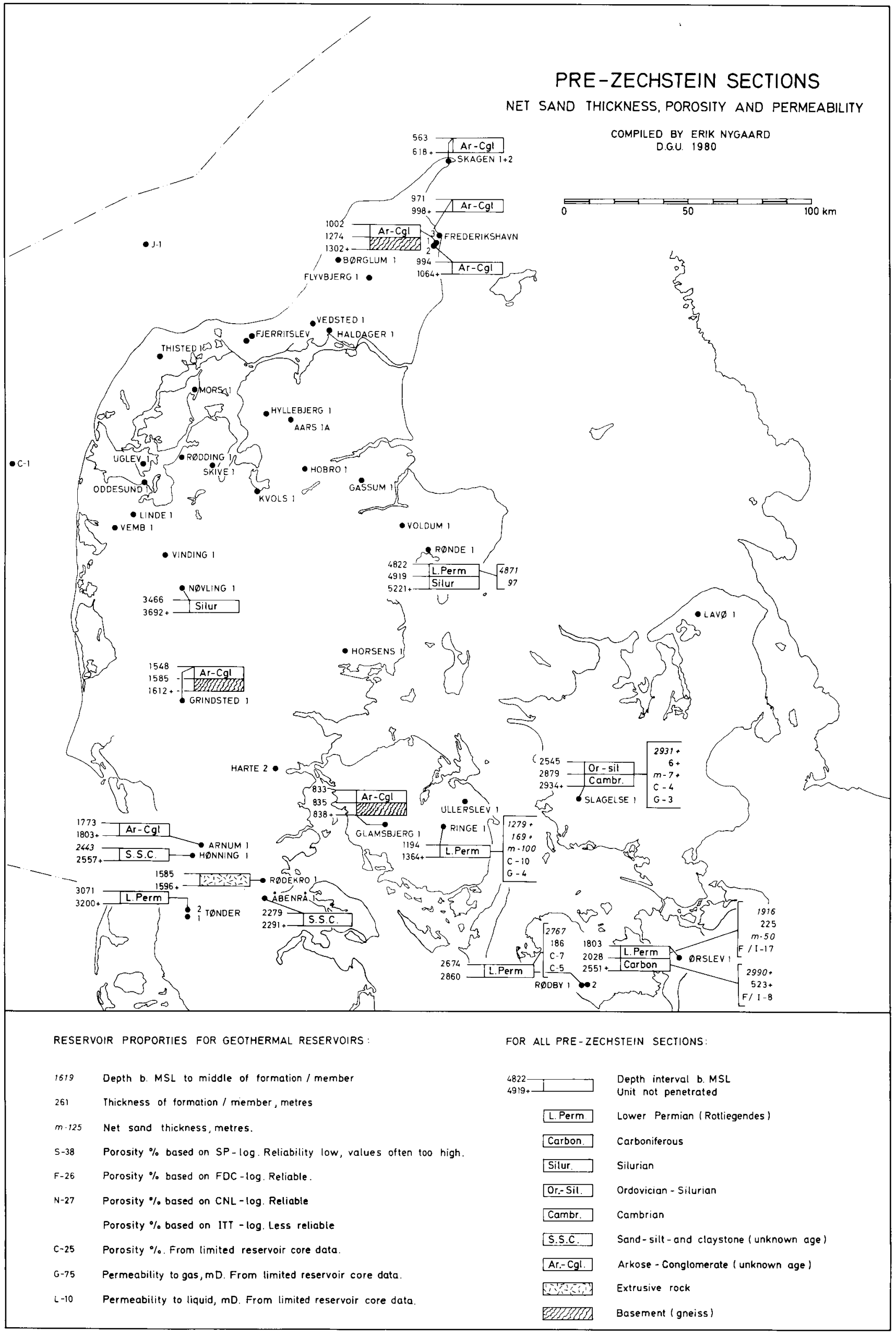

Fig. 9. Præ-zechstein aflejringer, samt deres net sand tykkelse, porøsitet og permeabilitet. 
mergelsten og lersten veksler, men kalkstenen dominerer i såvel de øverste $50 \mathrm{~m}$ som de nederste 100 meter af den gennemborede lagserie. Kalkstenen er hård, meget tæt, rådgrå til gråsort og rig på fragmenter af fossiler og andre kalkkorn. Kalkkornene udgør op til $30 \%$ af bjergarten, som herudover består af meget finkornet eller krystallinsk kalk.

Udbredelse, tykkelse og dybde: Karbon kalksten er kun fundet i boringen Ørslev 1 og må formodes kun at vare til stede $\mathrm{i}$ et lille område syd for Ringkøbing-Fyn Højderyggen. Der er anboret en $525 \mathrm{~m}$ tyk lagserie af hvilke kalksten udgør max. $200 \mathrm{~m}$.

Toppen af de karbone kalksten findes ved $2035 \mathrm{~m}$.

Porøsitet og permeabilitet: Porøsiteten i de bedste afsnit af karbonaten er $8 \%$.

Temperatur: Syd for Ringkøbing-Fyn Højderyggen vurderes temperaturen for $2000 \mathrm{~m}$ niveauet normalt at være $60-70^{\circ} \mathrm{C}$.

Sammenfattende bemorkninger: Kalkstenen er tæt og veksellejret med lersten. Den skønnes ikke at være et egnet geotermisk reservoir. Datamængden er meget lille.

\section{Rotliegendes sandsten}

Fig. 9. Appendix 1.

\section{Lithostratigrafisk inddeling: Ingen.}

Geologisk alder: Nedre perm, rotliegendes.

Lithologi: Sandsten og siltsten med indslag af ler. Farverne er rødbrune, og der er stedvist lidt kalksten og anhydritkonkretioner. De sandede-siltede lag har ofte en finkornet matriks, især syd for RingkøbingFyn Højderyggen.

Udbredelse, tykkelse og dybde: Rotliegendes sandstenen er især fundet syd for Ringkøbing-Fyn Højderyggen, men kun sporadisk på Højderyggen og $\mathrm{i}$ Det danske Subbassin. Den konstaterede tykkelse er syd for Højderyggen op til $225 \mathrm{~m}$, på Højderyggen $170 \mathrm{~m}$, og i Det danske Subbassin knapt $100 \mathrm{~m}$.

Top af rotliegendes sandstenen ligger syd for Ringkøbing-Fyn Højderyggen fra 1800 til 3100 m, på Højderyggen ved $1200 \mathrm{~m}$, og et enkelt sted centralt i Det danske Subbassin ved $4800 \mathrm{~m}$.

Porøsitet og permeabilitet: Porøsiteten synes i højere grad at afspejle lokale variationer i lithologi end en direkte dybdeafhængighed. Porøsiteten ligger generelt omkring $10 \%$, med en enkelt undtagelse på knapt 20\%. Permeabiliteten er ca. $4 \mathrm{mD}$.

Temperatur: Sandstenens temperatur vil for dybdeintervallet $1800-3100 \mathrm{~m}$ typisk være mellem $60 \mathrm{og}$ $80^{\circ} \mathrm{C}$, over Højderyggen ca. $40^{\circ} \mathrm{C}(1200 \mathrm{~m})$ og i Subbassinet omkring $140^{\circ} \mathrm{C}(4800 \mathrm{~m})$.
Sammenfattende bemarkninger: Rotliegendes sandstenen skønnes at være af ringe værdi som geotermisk reservoir. Datamængden er overordentlig begrænset.

\section{Zechstein kalksten syd for Ringkøbing-Fyn Højderyggen}

Fig. 10. Appendix 1.

Lithostratigrafisk inddeling: Z-1, Z-2 og Z-3 Karbonat Formationerne, Mellem Karbonat Member i Z-1 Anhydrit Formation (Clark og Tallbacka, 1980).

Geologisk alder: Øvre perm, zechstein.

Lithologi: Kalksten, der indgår som underordnet bestanddel i en serie cyklisk aflejret kalksten, anhydrit og stensalt.

Tre typer kalksten dominerer: En meget finkornet, en med op til $50 \%$ kalkkorn i en finkornet mellemmasse, og en med overvejende fine korn, som oprindeligt har været holdt sammen af algetråde eller i få tilfælde af bryozoer.

De groveste kalkstensaflejringer findes $i$ et bælte tæt ved og parallelt med Ringkøbing-Fyn Højderyggen, medens de finkornede kalksten forekommer sydligere i Det nordtyske Bassin.

Udbredelse, tykkelse og dybde: Aflejringsområdets centrale del, med de største zechstein lagtykkelser, ligger i Nordtyskland, og lagserien kiler ud op mod Ringkøbing-Fyn Højderyggen.

Kalkstens-formationerne er tykkest langs randen af aflejringsområdet, - langs Ringkøbing-Fyn Højderyggen, samlet 125 meter. Dybden til formationerne varierer fra 2000 til 3000 meter.

Porøsitet og permeabilitet: Kalkstenens porøsitet er lav, ca. $10 \%$, ligesom luftpermeabiliteten er nede på $1 \mathrm{mD}$. Diagenetiske omdannelsesprocesser har i dele af lagserien forårsaget opløsning og hulrumsdannelse. Små hulrum samt sprækkedannelser skaber sekundær porøsitet og permeabilitet, hvis størrelse er vanskelig at anslå.

Temperatur: I dybdeintervallet 2000 til $3000 \mathrm{~m}$ anses temperaturen i det aktuelle område normalt at være mellem ca. $60^{\circ} \mathrm{C}$ og ca. $90^{\circ} \mathrm{C}$.

Sammenfattende bemarkninger: Kendskabet til formations reservoiregenskaber er ringe, men det er muligt, at hulrum og sprækker kan forårsage at formationerne kan udnyttes til geotermisk produktion. 

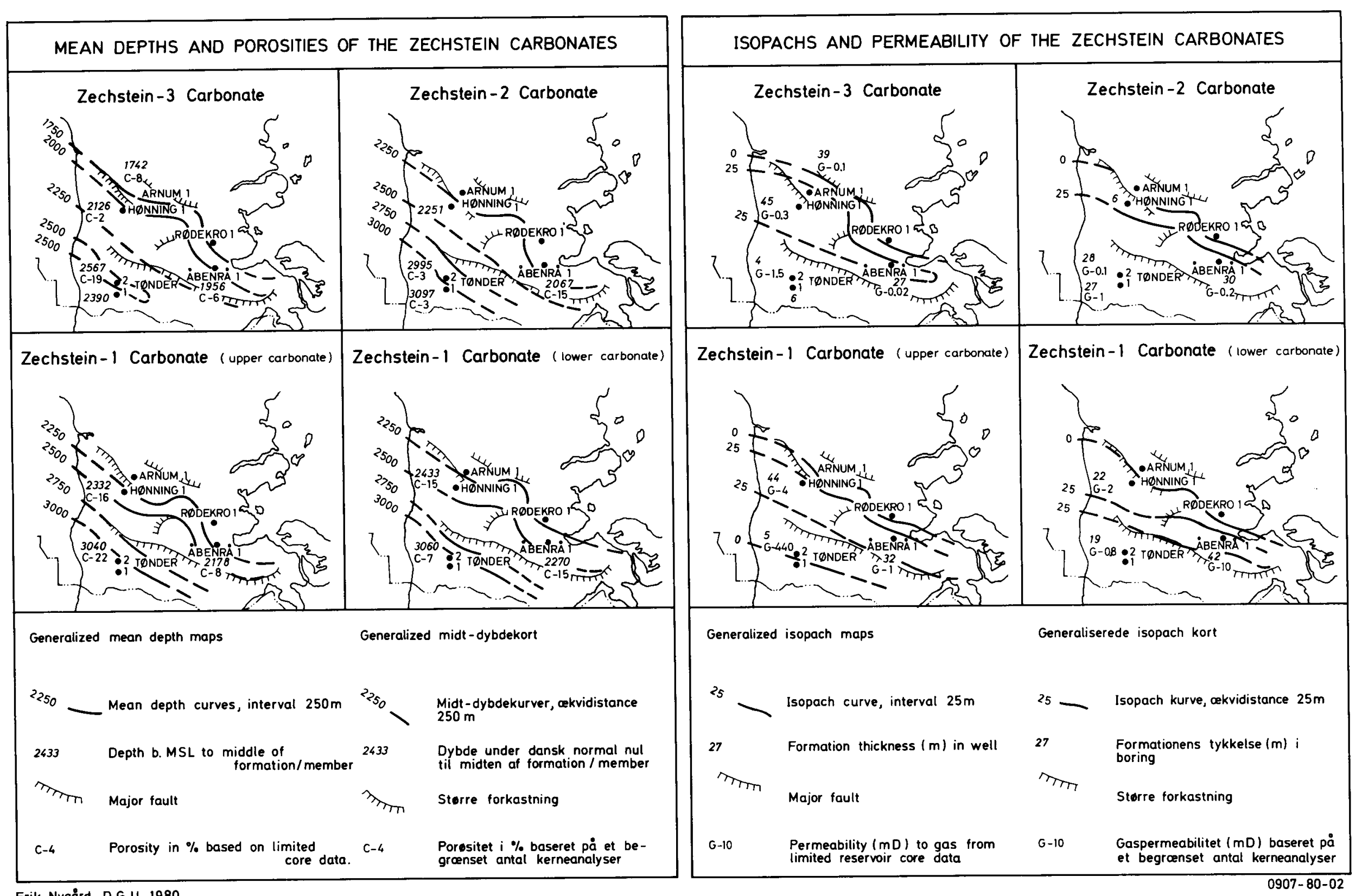

Erik Nygård D.G.U. 1980

Fig. 10. Kort over zechstein karbonatformationernes midt dybde, tykkelse, porøsitet og permeabilitet. 


\section{Trias}

\section{Bunter Sandsten Formation}

Fig. 11-14. Appendix 1.

Lithostratigrafisk inddeling: Bacton Group, Bunter Sandsten Formation (Bertelsen 1980).

Geologisk alder: Nedre trias, jakutien - nedre olenikien.

Lithologi: Rødbrune og gulbrune, finkornede sand-, silt- og lersten, der lokalt er stærkt kalk-, anhydritog glimmerholdige. Varierer fra finkornet sand- og siltsten syd for Ringkøbing-Fyn Højderyggen til fintil grovkornet sandsten i Det danske Subbassin. Længere mod nord findes Skagerrak Formationens grovkornede sandsten, der her behandles sammen med Bunter Sandsten Formationen.

Udbredelse, tykkelse og dybde: Bunter Sandsten Formationen findes i Det danske Subbasin, Det dansk-polske Trug og Det nordtyske Bassin samt delvis over Ringkøbing-Fyn Højderyggen.

Tykkelsen er mindre end $300 \mathrm{~m}$, dog undtaget depocentret i Det danske Subbassin, hvor mægtigheden af Bunter Sandsten Formation / Skagerrak Formationen overskrider $900 \mathrm{~m}$.

Over Ringkøbing-Fyn Højderyggen er lagserien tynd og mangler enkelte steder helt.

Net sand tykkelsen, der er vigtig i reservoirbedømmelsen, er tilsyneladende lokal betinget.

Bunter Sandsten Formationens top findes i 10001500 meters dybde over Ringkøbing-Fyn Højderyggen, faldende til cirka $2000 \mathrm{~m}$ i Sønderjylland i Det nordtyske Bassin. Centralt i Det danske Subbassin overstiger dybden til top af Bunter Sandsten/Skagerrak Formationen 5000 meter.

Porøsitet og permeabilitet: Porøsiteten aftager med dybden. I $1000-2000 \mathrm{~m}$ er porøsiteterne $20-30 \%$ medens de under $3000 \mathrm{~m}$ er lavere end $15 \%$ (fig. 11). Luftpermeabiliteter aftager med aftagende porøsitet. Højeste luftpermeabilitet er ca. $1000 \mathrm{mD}$.

Bedste porøsiteter og permeabiliteter i Bunter Sandsten Formationen må forventes umiddelbart nord og syd for Ringkøbing-Fyn Højderyggen, hvor formationen ikke ligger så dybt. Længst mod nord i Det danske Subbassin forventes Skagerrak Formationen lokalt at have gode reservoirkarakterer.

Temperatur: Over Ringkøbing-Fyn Højderyggen

\section{BUNTER SANDSTONE FORMATION/TONDER FORMATION}

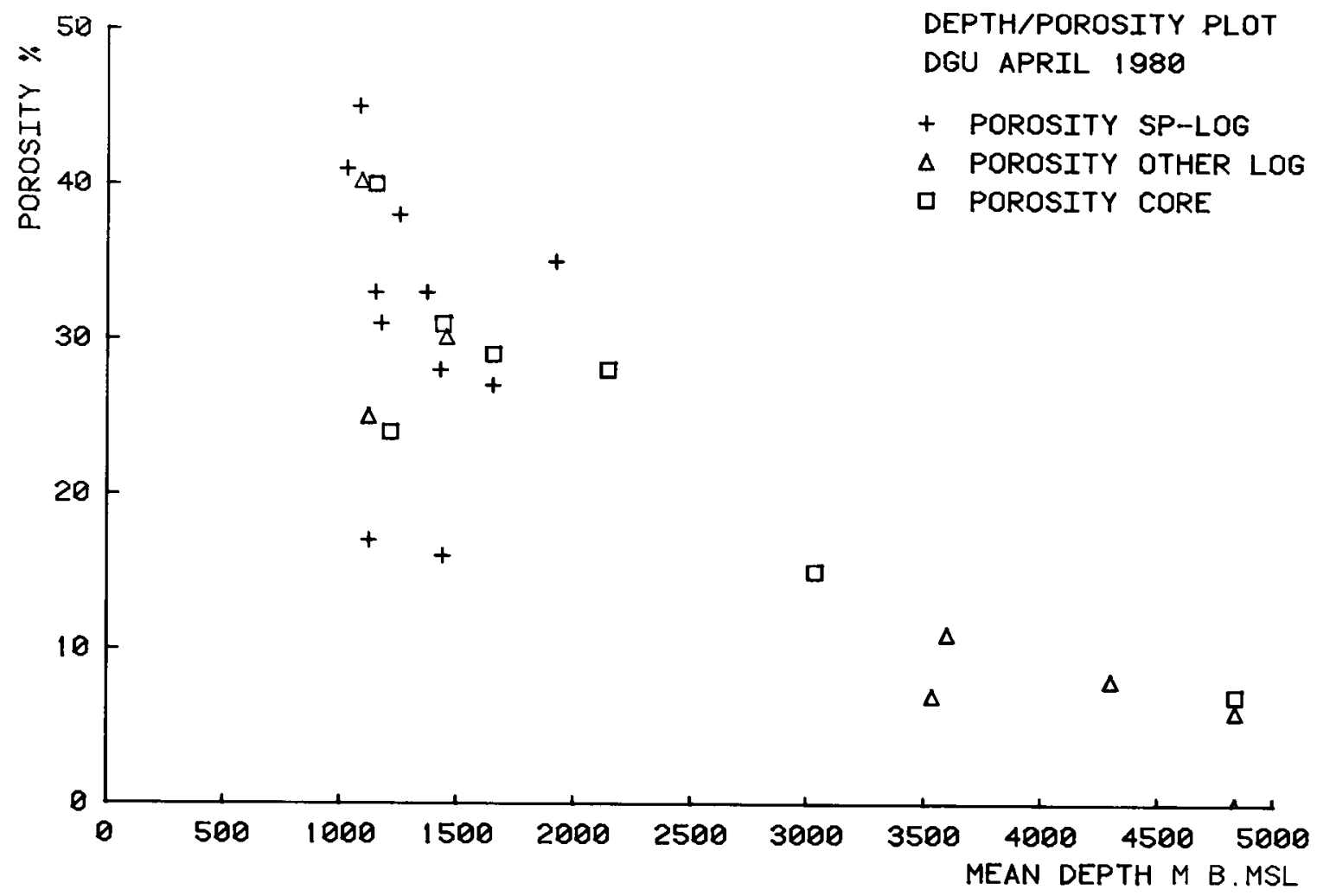

Fig. 11. Porøsitetsværdier for Bunter Sandsten Formation/Tønder Formation plottet mod dybden. Det ses, at porøsiteten generelt aftager med dybden. Hvert punkt repræsenterer en boring. Værdierne stammer fra tabellen i appendix 1. 


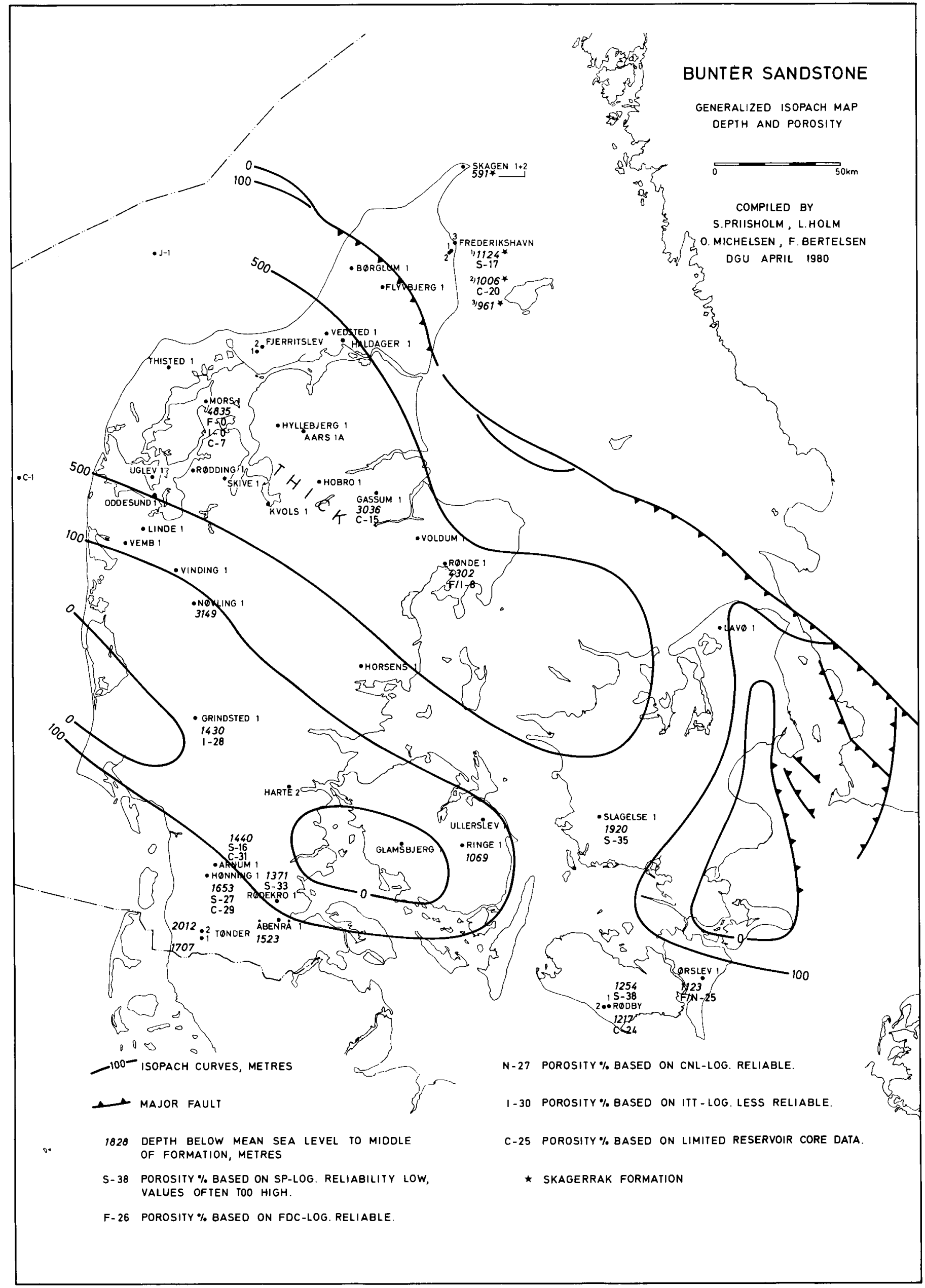

Fig. 12. Bunter Sandsten Formationen. Generaliseret tykkelse, dybde og porøsitet. 


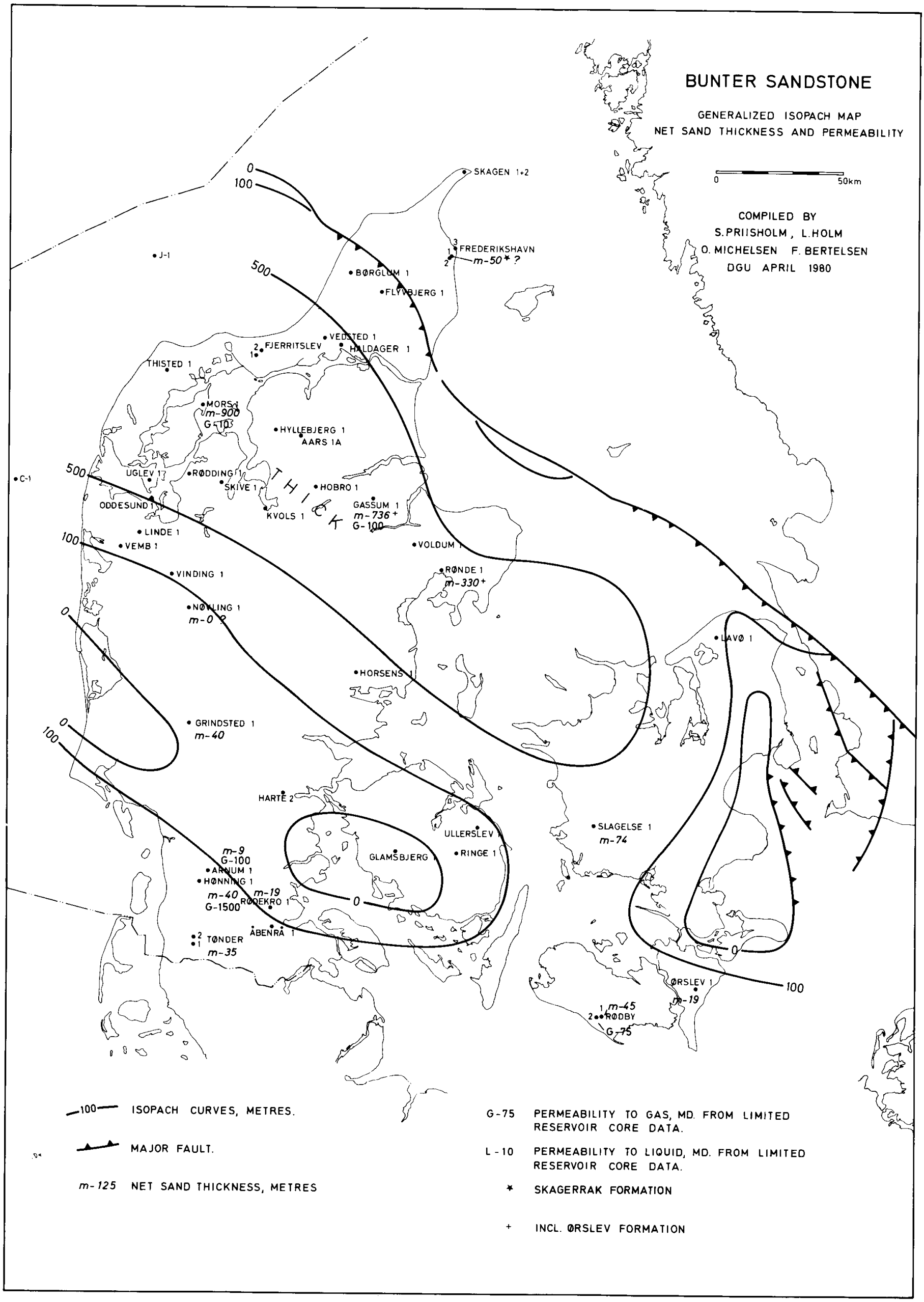

Fig. 13. Bunter Sandsten Formationen. Generaliseret tykkelse, net sand tykkelse og permeabilitet. 


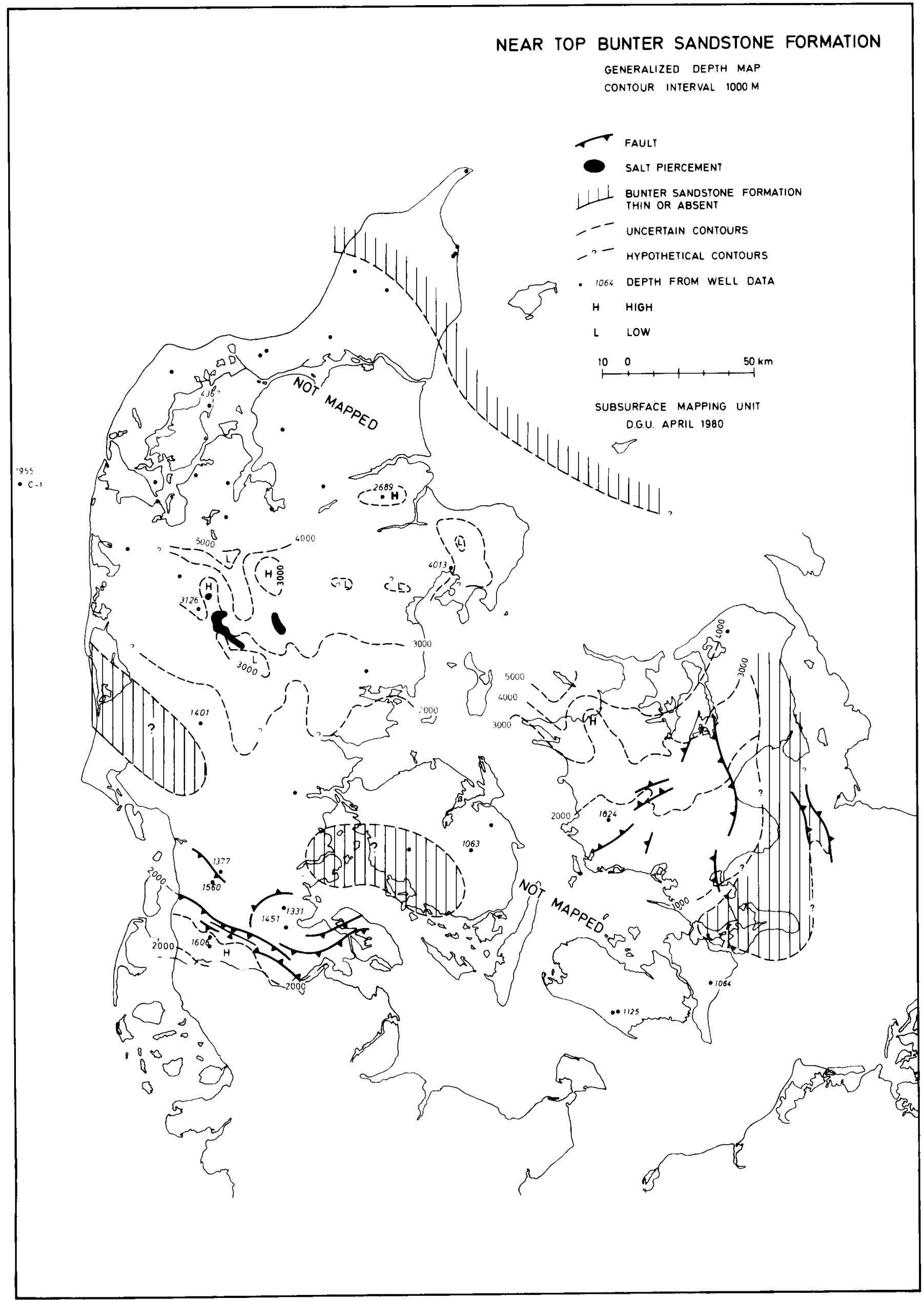


Approximate Base Triassic

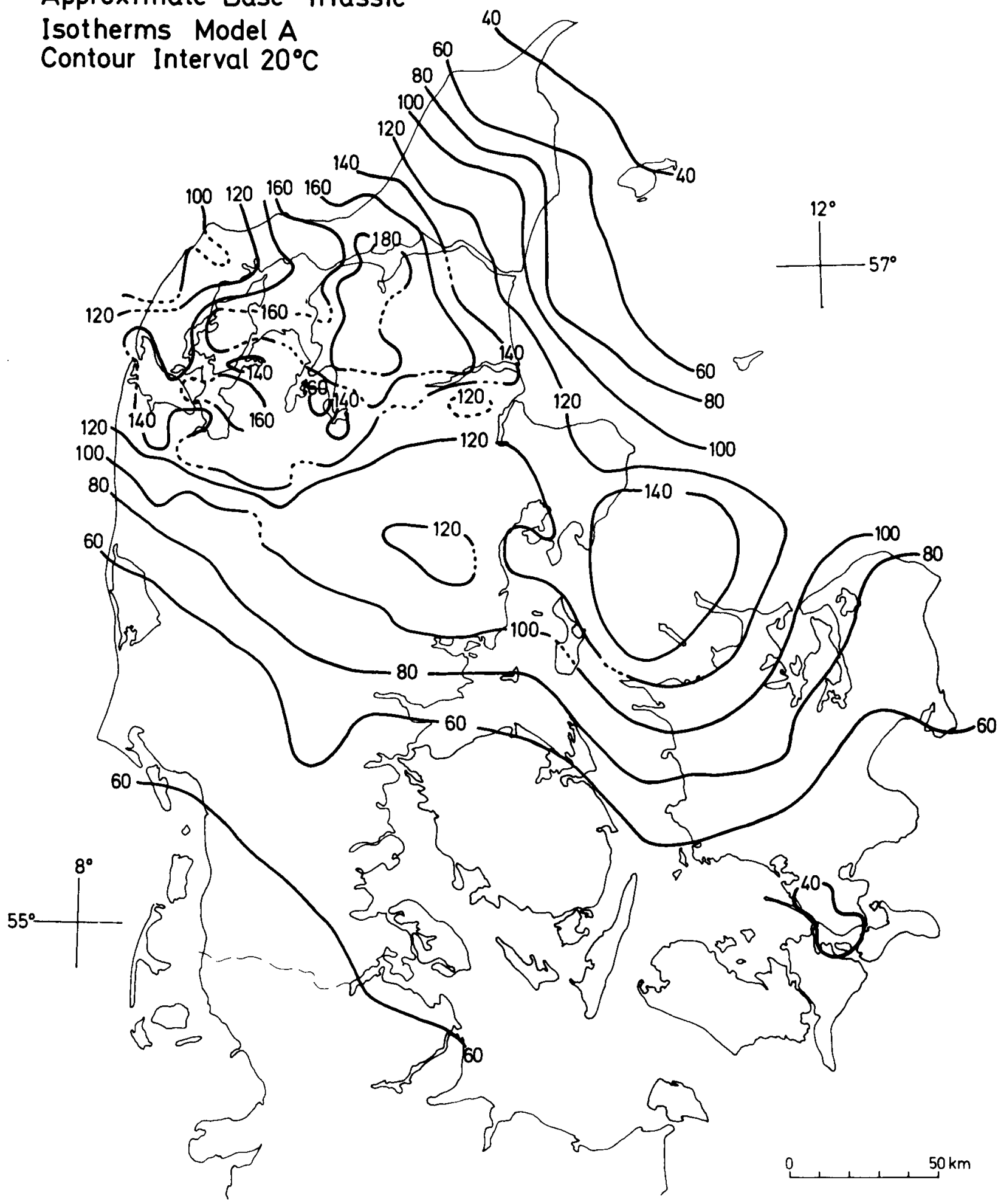

Fig. 15. Isotermer for basis trias. Model A. 
vurderes temperaturen at være $30-50^{\circ} \mathrm{C}$, i Sønderjylland $60-80^{\circ} \mathrm{C}$. I Mors 1 boringen giver korrigerede BHT-værdier temperaturer mellem ca. $110^{\circ} \mathrm{C} \mathrm{og}$ ca. $140^{\circ} \mathrm{C}$. Centralt i Subbassinet overstiger temperaturen $140^{\circ} \mathrm{C}$. Model A isotermer for en niveauflade, der approksimativt udgør basis af trias, fremgår af fig. 15.

Sammenfattende bemarkninger: Dybdekortet for Bunter Sandsten Formationen er behæftet med væsentlig usikkerhed, idet relevante hastighedsfunktioner til brug for dybdekonverteringen i det væsentlige har manglet.

Muligheden for vurdering af reservoirparametrene er begrænset, idet Bunter Sandsten Formationen kun er kendt fra spredte boringer, kernedata er få og porøsiteter i det væsentlige begrænset til beregninger ud fra SP-resistivitetsmålinger.

Om end kendskabet til formationen er begrænset skønnes det, på det foreliggende grundlag, at Bunter Sandsten Formationen har geotermiske reservoirkarakterer.

\section{Ørslev Formation}

Fig. 16.

Lithostratigrafisk inddeling: Lolland Group, Ørslev Formation (Bertelsen 1980).

Geologisk alder: Nedre - mellem trias (röt), øvre olenikien - nedre anisien.

Lithologi: Formationen kan deles i en nedre og en øvre del. I den sydlige del af landet består den nedre del af stensalt og anhydrit mellemlejret af rødbrun grå lersten. Mod nord veksler lys grågrøn dolomitisk kalksten med lersten og mergelsten. Den øvre del af formationen består af siltholdig, rødbrun lersten. Indeslutninger af anhydrit forekommer $i$ hele formationen. Ligeledes forekommer siltsten, der på overgangen til Skagerrak Formationen i Det danske Subbassin kan dominere dele af lagserien.

Udbredelse, tykkelse og dybde: Ørslev Formationen findes i størstedelen af landet (fig. 16).

Tykkelsen er i almindelighed 100-300 meter, tyndere over Ringkøbing-Fyn Højderyggen og over 400 meter tyk i den centrale del af Det danske Subbassin.

Net sand tykkelsen er inkluderet i og tabelleret under Bunter Sandsten Formationen. Den totale mægtighed af sand-siltsten er 50-150 m i overgangszonen til Skagerrak Formationen.

Ørslev Formationens top findes i 800-1500 meters dybde over Ringkøbing-Fyn Højderyggen, faldende til 1800-2000 meter i den danske del af Det nordtyske Bassin. Centralt i Det danske Subbassin, i overgangszonen til Skagerrak Formationen, ligger top af formationen dybere end $4000 \mathrm{~m}$.

Porøsitet og permeabilitet: Porøsiteten er ringe, 3-5\%. Permeabiliteten antages at være ubetydelig på grund af bjergartens finkornethed.

Temperatur: Centralt i Det danske Subbassin anses formationens temperatur for dybder over $4000 \mathrm{~m}$ typisk at være over $120^{\circ} \mathrm{C}$. Over Ringkøbing-Fyn Højderyggen $35-50^{\circ} \mathrm{C}$ stigende til $60-70^{\circ} \mathrm{C}$ syd for Højderyggen.

Sammenfattende bemarkninger: Kendskabet til formationens reservoiregenskaber er ringe, men det skønnes at reservoirkaraktererne er for dårlige til geotermisk udnyttelse. En undtagelse kan være overgangen til Skagerrak Formationen hvor nedre og mellem trias skal vurderes samlet.

\section{Falster Formation}

Fig. 17.

Lithostratigrafisk inddeling: Lolland Group, Falster Formation (Bertelsen 1980).

Geologisk alder: Mellem trias (muschelkalk); anisien - nedre ladinien.

Lithologi: Vekslende grå og grågrønne, sjældnere brune, lersten, mergelsten og kalksten. Anhydrit forekommer spredt. Den nedre del af formationen er generelt rigere på kalksten, medens den øvre er mere leret. I Det dansk Subbassin, nær overgangen til Skagerrak Formationen, forekommer sandede indslag.

Udbredelse, tykkelse og dybde: Falster Formationen findes i størstedelen af landet (fig. 17).

Tykkelsen af formationen er generelt 100-200 meter, medens net sand tykkelsen er yderst minimal. Enkelte 5 meter tykke sand-siltstenslag findes i overgangszonen til Skagerrak Formationen. Falster Formationens top findes i 800-1200 meters dybde over Ringkøbing-Fyn Højderyggen, faldende til 1500 meter mod Det nordtyske Bassin. I Det danske Subbassins centrale dele ligger formationen dybere end 3700 meter.

Porøsitet og permeabilitet: Porøsiteten er lav, omkring $10 \%$. På baggrund af formationens blandede lithologi med kalksten og anhydrit kan det forventes, at sandstenslag er delvis cementerede og har ringe permeabilitet.

Temperatur: Syd for Ringkøbing-Fyn Højderyggen vurderes temperaturen at være omkring $60^{\circ} \mathrm{C}$ faldende over Højderyggen til $30-40^{\circ} \mathrm{C}$ og stærkt stigende til over $100^{\circ} \mathrm{C}$ centralt i Subbassinet.

Sammenfattende bemarkninger: Kendskabet til 


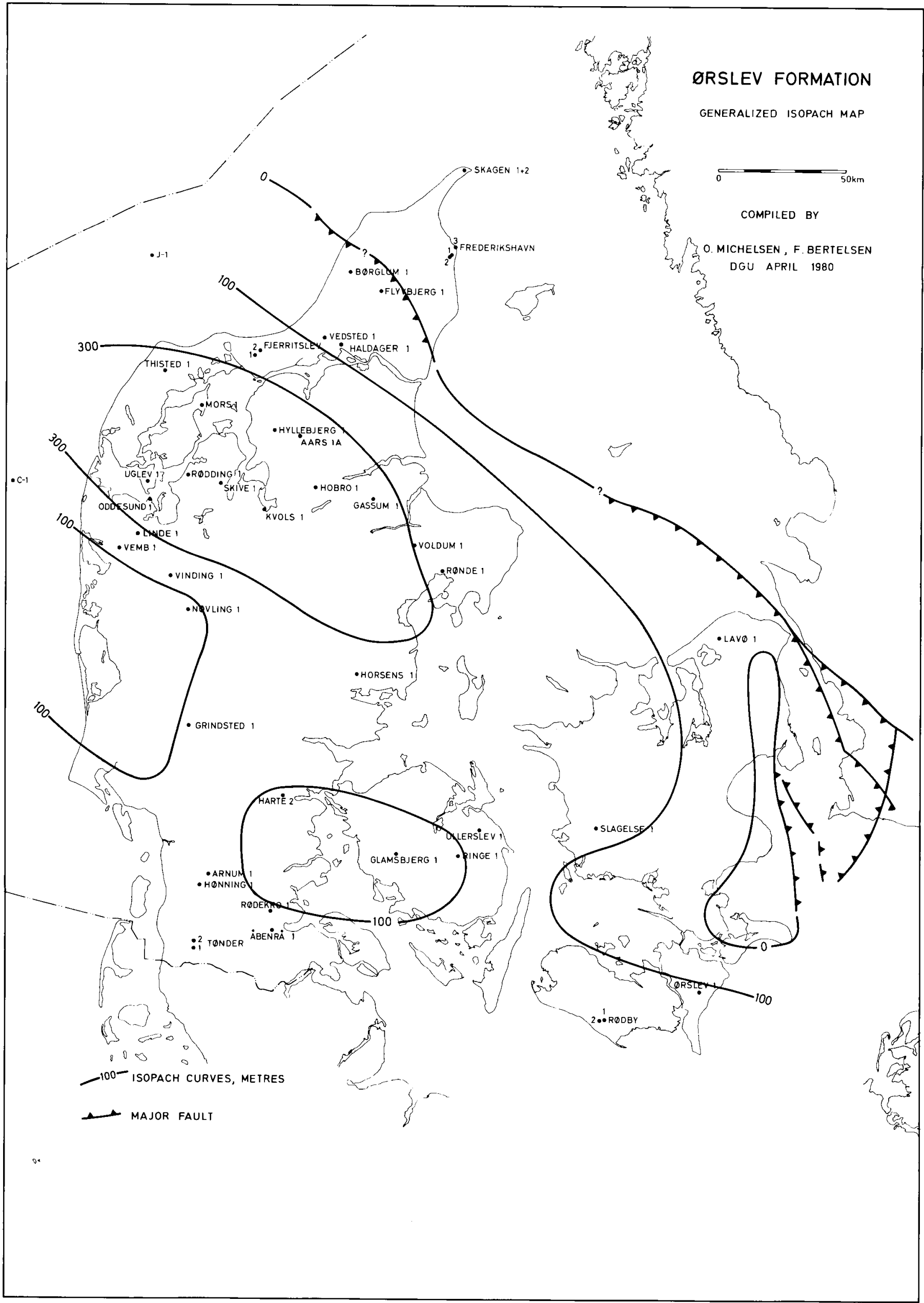

Fig. 16. Ørslev Formationen. Generaliseret tykkelse. 


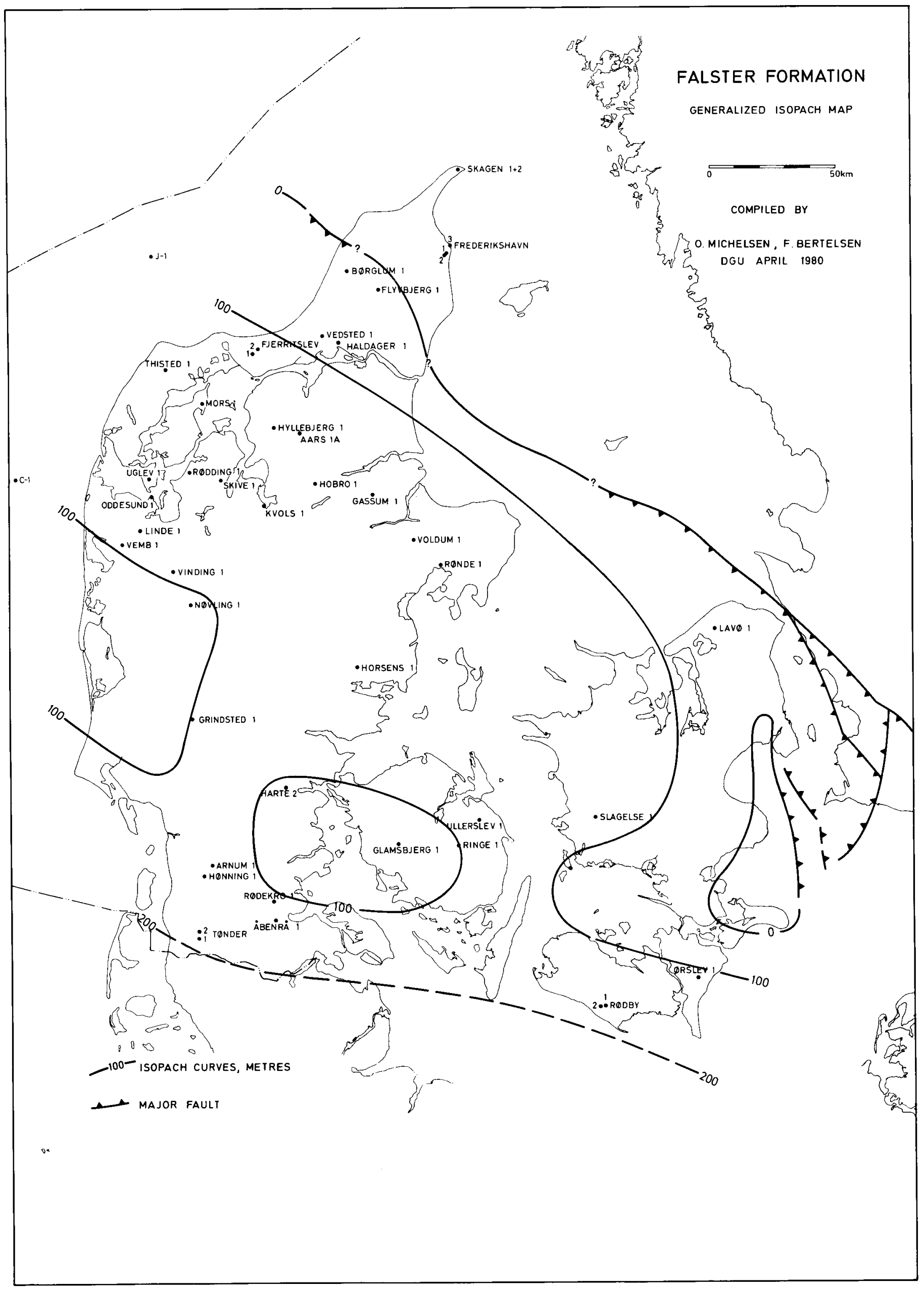

Fig. 17. Falster Formationen. Generaliseret tykkelse. 
reservoiregenskaber i formationen er ringe, men det skønnes, at formationen ikke er egnet til geotermisk udnyttelse.

\section{Tønder Formation}

Fig. 11, 18-19. Appendix 1.

Lithostratigrafisk inddeling: Jylland group, Tønder Formation (Bertelsen 1980).

Geologisk alder: Mellem trias (nedre keuper); øvre ladinien.

Lithologi: Rødlig brun til grønlig, siltholdig lersten med spredte anhydritindeslutninger. Øverst i formationen findes enkelte, velafgrænsede lag af grågrøn og rødbrun siltholdig, finkornet sandsten.

Mod nord, i Det dansk Subbassin, tiltager sandindholdet samtidig med at lagene bliver hyppigere, men tyndere og sorteringsgraden dårligere.

Udbredelse, tykkelse og dybde: Tønder Formationen findes i størstedelen af landet, men kan mangle over Ringkøbing-Fyn Højderyggen. Mod nord-nordvest går formationen over i Skagerrak Formationen. I den sydøstlige del af Det danske Subbassin ændrer lagene karakter og henføres til Ringe Beds (se Bertelsen 1980). Sandlagene i Ringe Beds er her medregnet til Tønder Formationen.

Gennemsnitlig tykkelse er 100-300 meter. Net sand tykkelsen dog kun 20-40 meter, stigende til 100 meter i Det danske Subbassin.

Dybden til top af formationen er 1000-1500 meter i Sønderjylland, mindre over Ringkøbing-Fyn Højderyggen, ca. 800-1000 meter. I Det danske Subbassin overstiger dybden 3500 meter.

Porøsitet og permeabilitet: Porøsitetsværdierne er meget svingende. I velafgrænsede sandlag, der findes i Sønderjylland, er porøsiteten $20-30 \%$ og derover. Porøsiteten er lavere (fig. 18) i Det danske Subbassins sandede aflejringer. De lave porøsiteter kan skyldes sandlagenes lerindhold samt graden af cementering med bl.a. calcit og anhydrit. Porøsiteten aftager med dybden, fra 30-40\% i 1000 meters dybde til $10 \%$ i 3500 meter (fig. 11). I bjergarter med gode reservoirkarakterer er luftpermeabiliteten 1000 $\mathrm{mD}$, men i lav-porøse sandlag vil permeabiliteten være markant lavere.

Endret aflejringstype samt graden af cementering kan bevirke, at porøsitets og permeabilitetsforholdene ændrer karakter over korte afstande.

Temperatur: De højeste temperaturer opnås centralt i Det danske Subbassin, hvor der kan forventes over $100^{\circ} \mathrm{C}$. På nordflanken af Ringkøbing-Fyn Højderyggen anses ca. $75^{\circ} \mathrm{C}(2300 \mathrm{~m})$ for at være typisk, og hvor formationen findes over Højderyggen kun $30-40^{\circ} \mathrm{C}$ stigende til ca. $50^{\circ} \mathrm{C}$ syd for Højderyggen.

Sammenfattende bemarkninger: Muligheden for vurdering af reservoirparametrene er begrænset, idet Tønder Formationen kun er kendt fra spredte boringer, kernedata er få og porøsiteter i det væsentlige begrænset til beregninger ud fra SP-resistivitetsmålinger.

Om end kendskabet til formationen er begrænset skønnes det på foreliggende grundlag, at Tønder Formationen lokalt har geotermiske reservoirkarakterer.

\section{Gassum Formation}

Fig. 20-26. Appendix 1.

Lithostratigrafisk inddeling: Mors Gruppe, Gassum Formation (Bertelsen 1978, 1980).

Geologisk alder: Gassum Formationen er diakron. I den centrale del af Det danske Subbassin er den af øvrige triassisk alder (rhaetien) mens den i den nordlige del af bassinet hovedsagelig er af nedre jurassisk alder (hettangien - sinemurien).

Lithologi: Overvejende fin- til mellemkornede, lysegrå sandsten, der veksler med mørkere farvede lersten og siltsten. Små kullag forekommer spredt. Formationen kan generelt underinddeles i tre enheder, en nedre og en øvre sandet enhed med en mellemliggende leret og siltet del. Lokalt kan yderligere enheder forekomme. Formationen bliver mere finkornet og leret mod syd.

Udbredelse, tykkelse og dybde: Gassum Formationen findes primært i Det danske Subbassin. Her har den en generel tykkelse på 100-200 m. I to områder (Nordsjælland og Ålborg området) overstiger tykkelsen $200 \mathrm{~m}$, mens formationen tynder ud mod Den fennoskandiske Randzone og Ringkøbing-Fyn Højderyggen.

Net sand tykkelsen kan variere meget lokalt. Generelt er den over $50 \mathrm{~m}$ i den centrale del af Det danske Subbassin (Sydvendsyssel / Himmerlandområdet) og i Nordsjælland. Syd for Ringkøbing-Fyn Højderyggen er der lokalt over $50 \mathrm{~m}$ net sand (sydlige Lolland-Falster).

Gassum Formationen ligger dybest i den centrale del af Det danske Subbassin (syd for Limfjorden), hvor dybden til top af formationen varierer fra 2500 $\mathrm{m}$ til $4000 \mathrm{~m}$. Dette område er samtidig stærkt influeret af saltstrukturer, hvorfor dybden kan variere meget lokalt. I et bælte parallelt med Den fennoskandiske Randzone, strækkende sig fra Djursland til Nordsjalland overstiger dybden $2500 \mathrm{~m}$. Fra disse to 


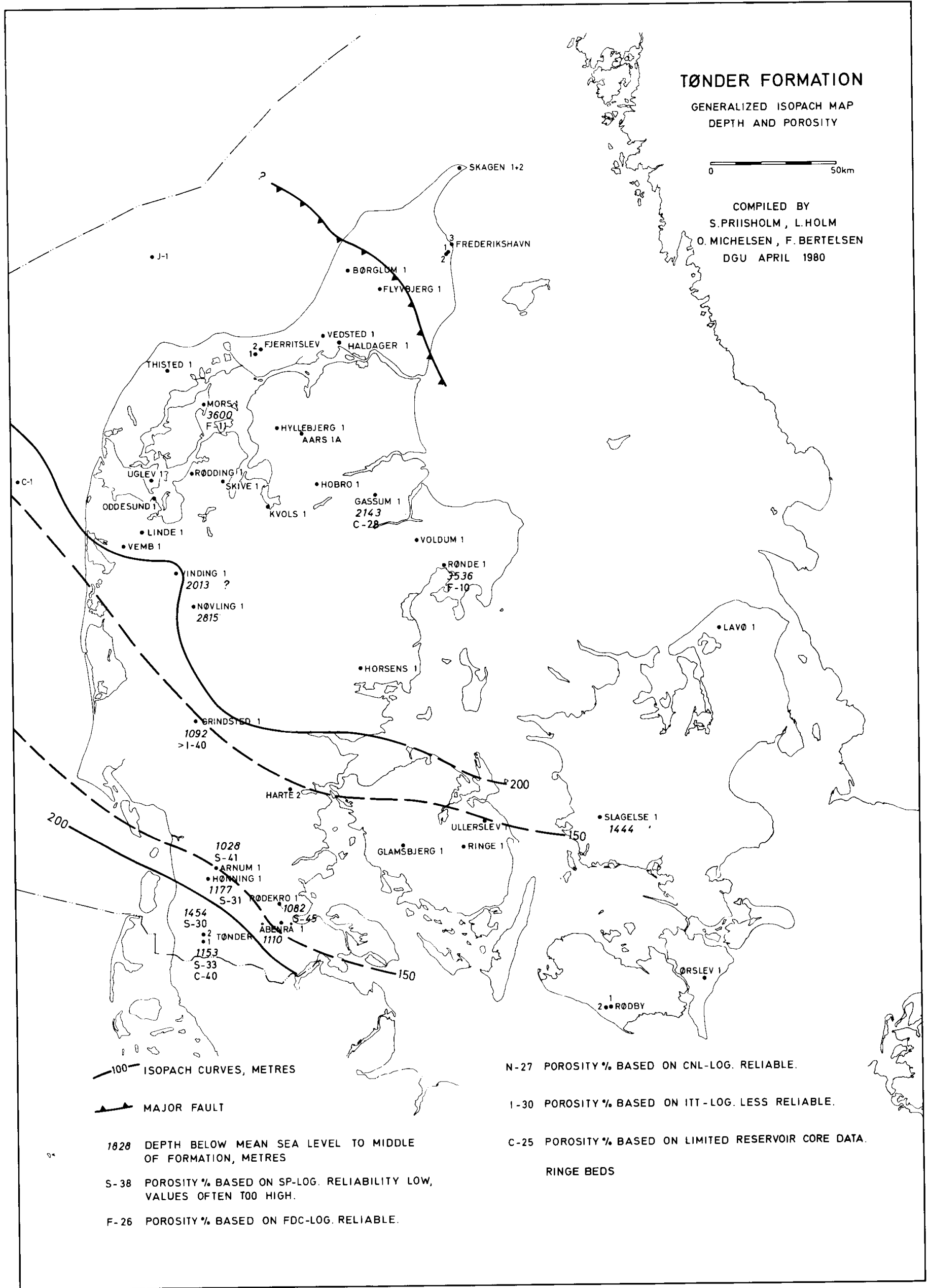

Fig. 18. Tønder Formationen. Generaliseret tykkelse, dybde og porøsitet. 


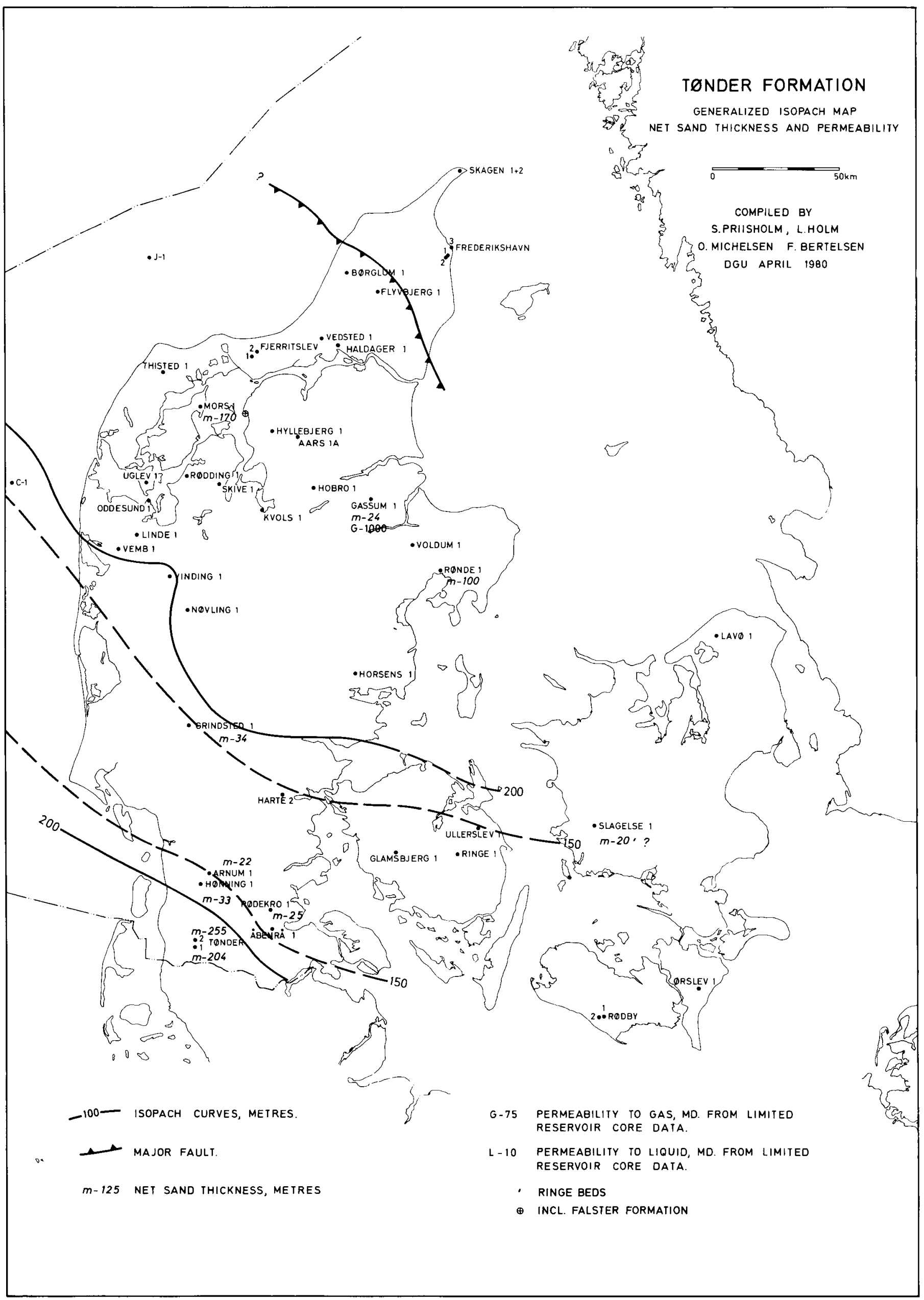

Fig. 19. Tønder Formationen. Generaliseret tykkelse, net sand tykkelse og permeabilitet. 
områder aftager dybden jæunt mod syd og mod nordøst til 500-1000 m.

Porøsitet og permeabilitet: Porøsiteten aftager med dybden. Ned til $1500 \mathrm{~m}$ er porøsiteten $30-40 \%$, omkring $2000 \mathrm{~m}$ ca. $25 \%$ og ved $3000 \mathrm{~m}$ ca. $12 \%$. Permeabiliteten aftager generelt med aftagende porøsitet og dermed med dybden. Da andre faktorer, så som sandstenens kornstørrelse og lerindhold, også har indflydelse på permeabiliteten, kan en generel afhængighed af porøsiteten og dybden ikke altid etableres. Dette gælder sedimenterne i Frederikshavn 2 og Skagen 2, som har en meget lav permeabilitet $\mathrm{i}$ forhold til porøsiteten. De øvrige data viser at væskepermeabiliteten varierer fra $8 \mathrm{mD}$ i $3200 \mathrm{~m}$ 's dybde til $300 \mathrm{mD}$ i $1500 \mathrm{~m}$ 's dybde.

Temperatur: I 1000,2000 og $3000 \mathrm{~m}$ vurderes Gassum Formationens temperatur typisk at ligge inden for intervallerne henholdsvis $35-45^{\circ} \mathrm{C}, 60-75^{\circ} \mathrm{C}$ og $80-110^{\circ} \mathrm{C}$. De højeste temperaturer på 100$120^{\circ} \mathrm{C}$ forventes centralt i Det danske Subbassin, hvor der i en dybde på ca. $3300 \mathrm{~m}$ er målt $107^{\circ} \mathrm{C}$. Model A isotermerne for nær top trias (fig. 24) anses for at give det bedste grundlag for en regional vurdering. Centralt i Subbassinet er der fundet god overensstemmelse mellem disse modelværdier og de må- leresultater, der foreligger. Størst usikkerhed er knyttet til områderne i det nordligste Jylland, ved Ringkøbing-Fyn Højderyggen og på Sjælland, hvor model $\mathrm{B} \operatorname{og} \mathrm{C}$ isotermerne (fig. $25 \operatorname{og} 26$ ) må medtages i vurderingen. For områder, hvor dybden og den geotermiske flux er konstante, vil en overlejring af Fjerritslev Formationen med stor mægtighed og øvre kridt kalksten med lav mægtighed give optimale temperaturbetingelser. Det skyldes Fjerritslev Formationens lave og kalkstenens forholdsvis høje ledningsevne. Over store områder i Nordjylland er temperaturen mellem 70 og $100^{\circ} \mathrm{C}$.

Sammenfattende bemarkninger: Dybdekortet for Gassum Formationen er i Nordjylland og på Sjælland behæftet med ringe usikkerhed, mens resten af landet har en større usikkerhed på grund af mangelfuld seismisk dækning og/eller hastighedsanalyser.

Muligheden for vurdering af reservoirparametrene er rimelige i det nordjyske område. Dog er der nogen usikkerhed med hensyn til permeabiliteten i dybdeintervallet $2-3 \mathrm{~km}$, idet mængden af kernemateriale herfra er meget lille. For resten af landet er en vurdering af reservoirparametrene forbundet med betydelig usikkerhed på grund af de spredte boredata.

På det foreliggende grundlag skønnes, at Gassum

GASSUM FORMATION

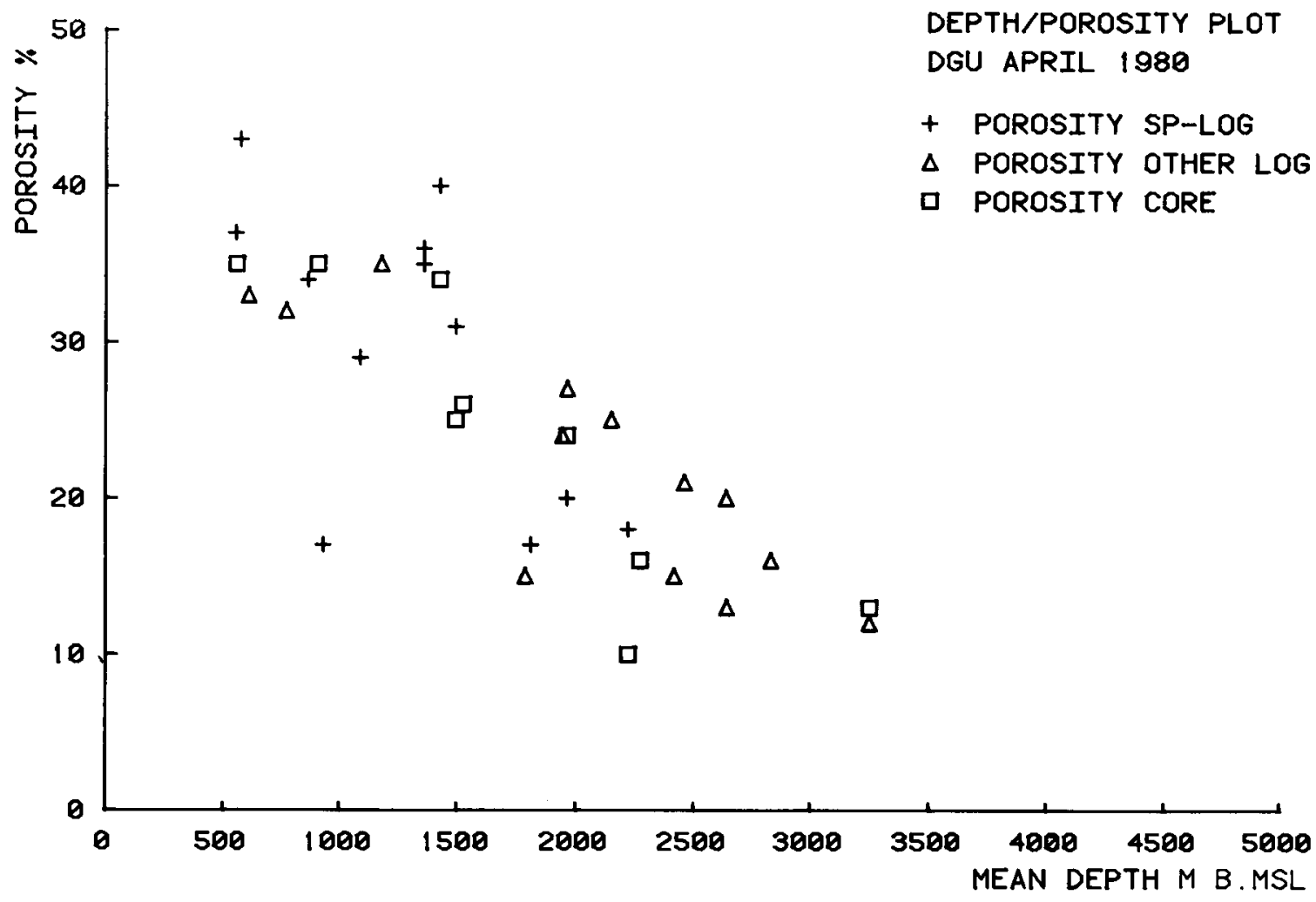

Fig. 20. Porøsitetsværdier for Gassum Formation plottet mod dybden. Det ses, at porøsiteten generelt aftager med dybden. Hvert punkt repræsenterer en boring. Værdierne stammer fra tabellen i appendix 1. 


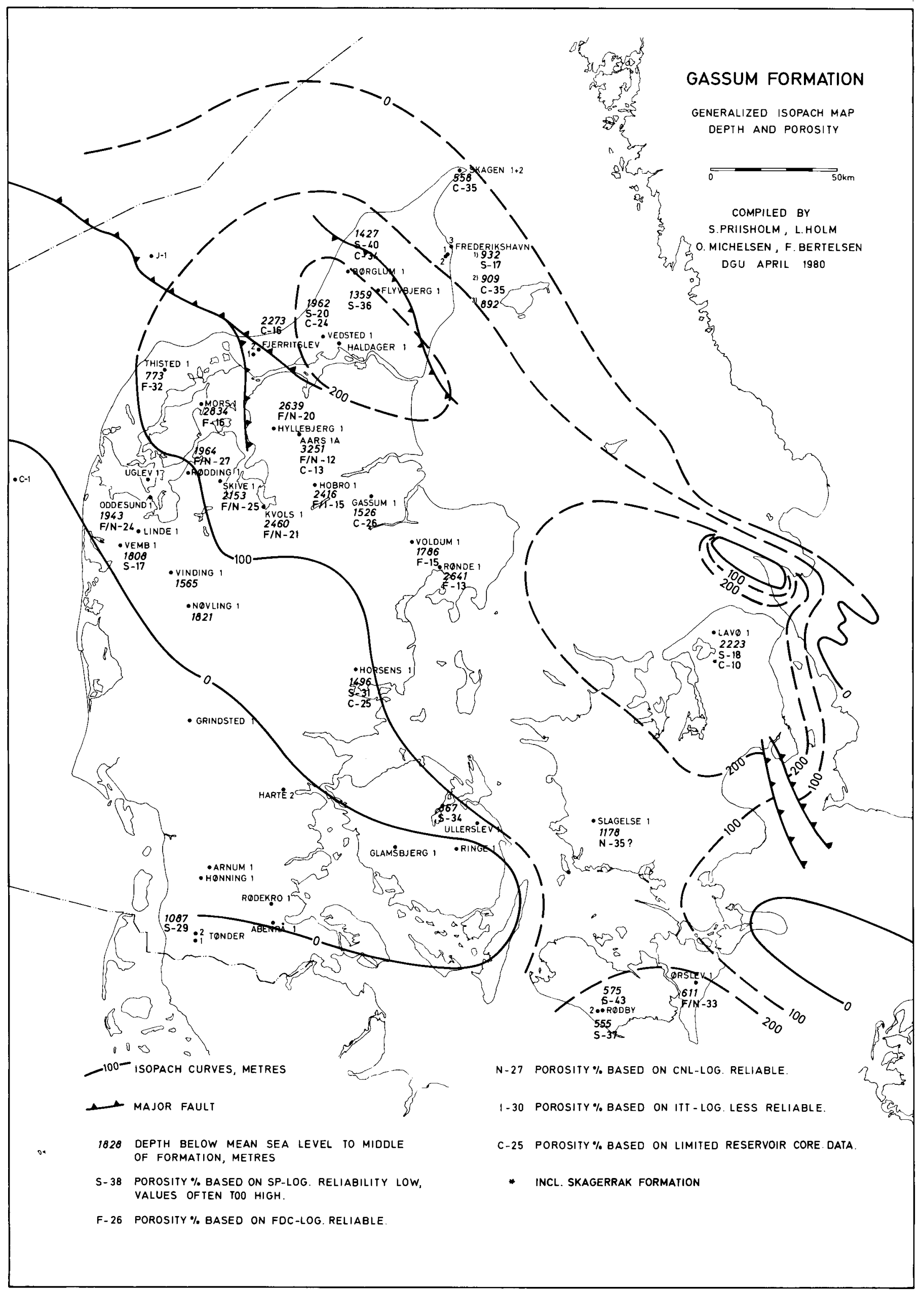

Fig. 21. Gassum Formationen. Generaliseret tykkelse, dybde og porøsitet. 


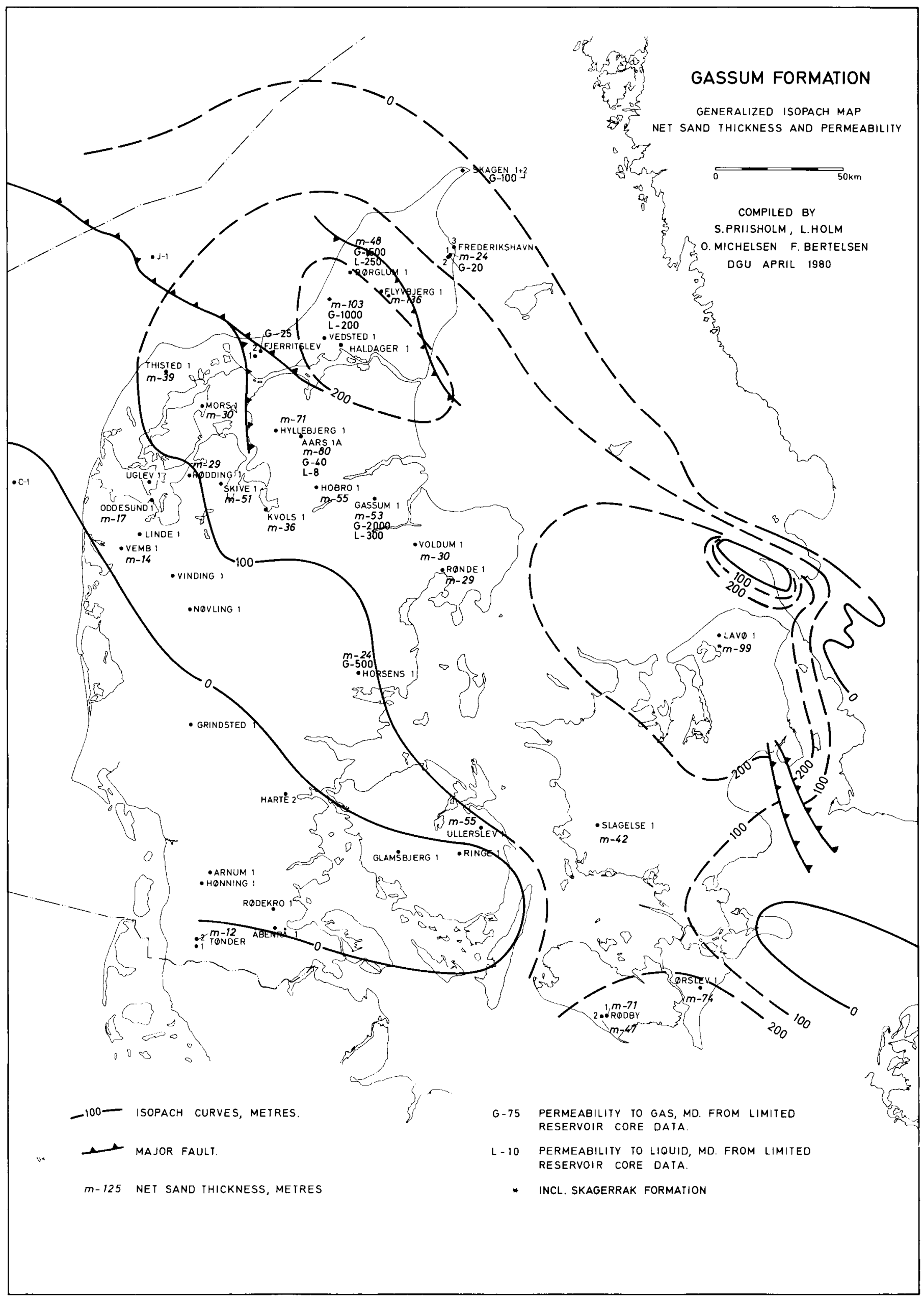

Fig. 22. Gassum Formationen. Generaliseret tykkelse, net sand tykkelse og permeabilitet. 


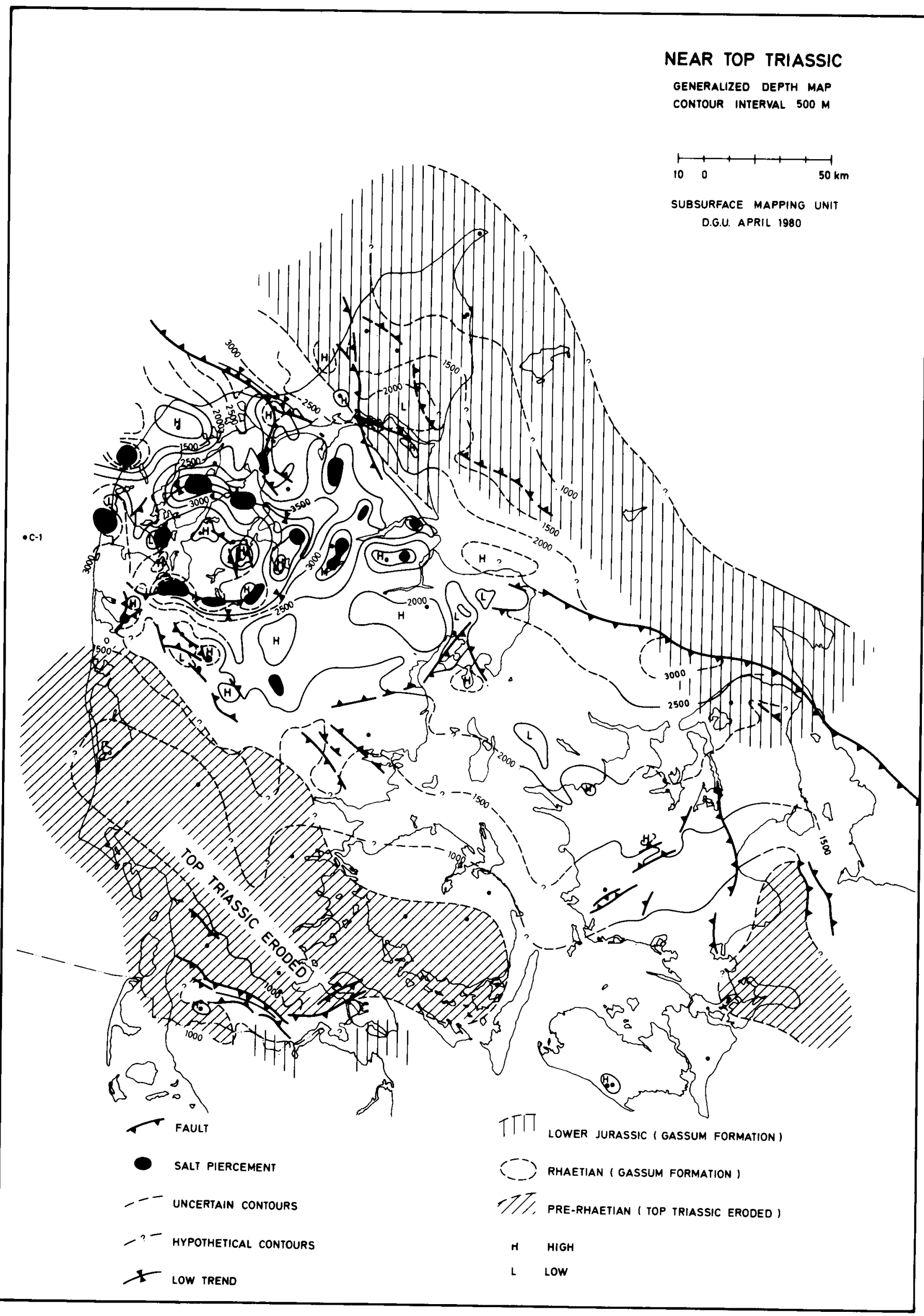

Fig. 23. Generaliseret dybdekort for en flade nær top af de triassiske aflejringer. 
Near Top Triassic

Isotherms Model A

Contour Interval $10^{\circ} \mathrm{C}$

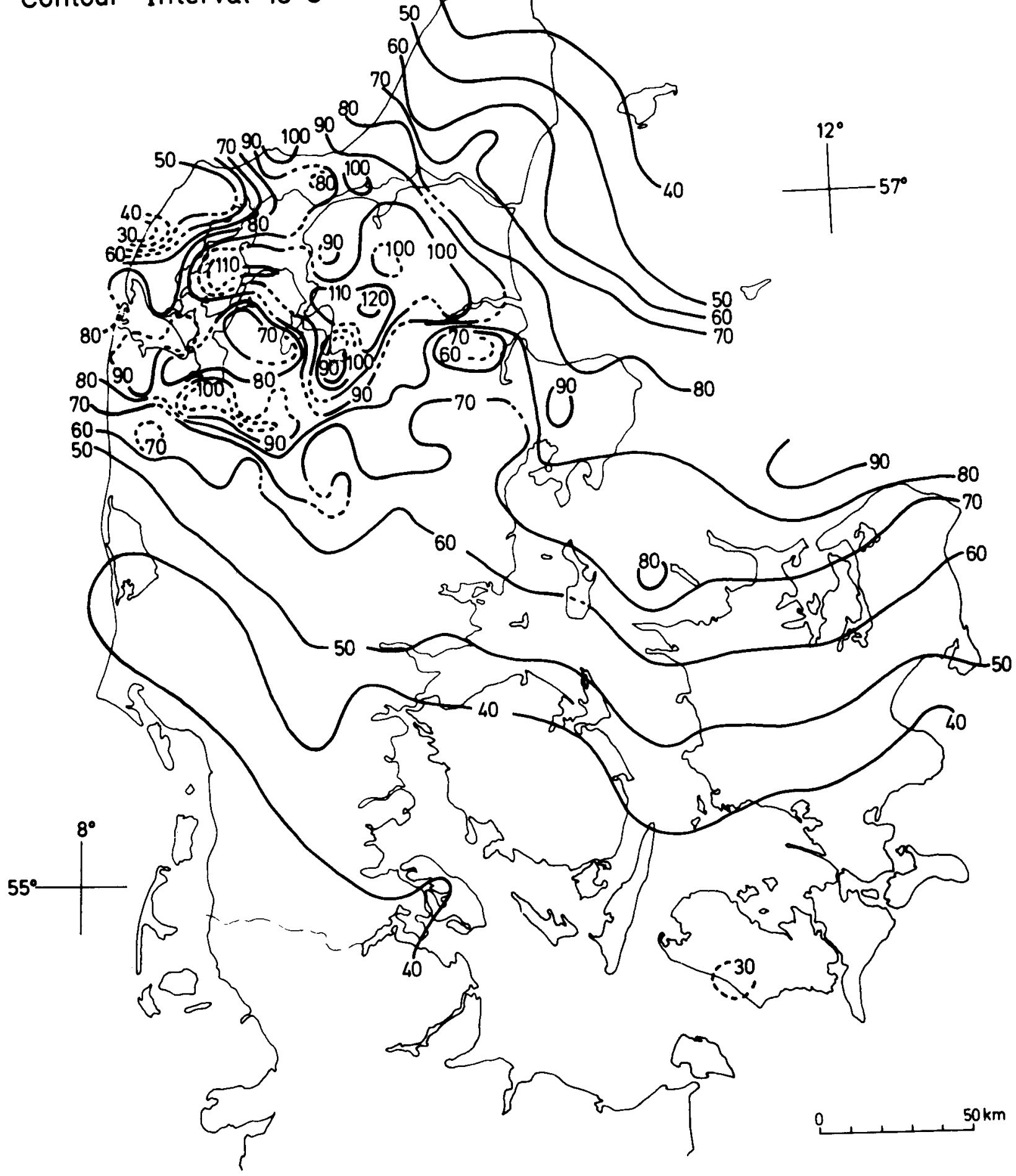

Fig. 24. Isotermer for top trias. Model A. 
Near Top Triassic

\section{Isotherms Model B}

Contour Interval $10^{\circ} \mathrm{C}$

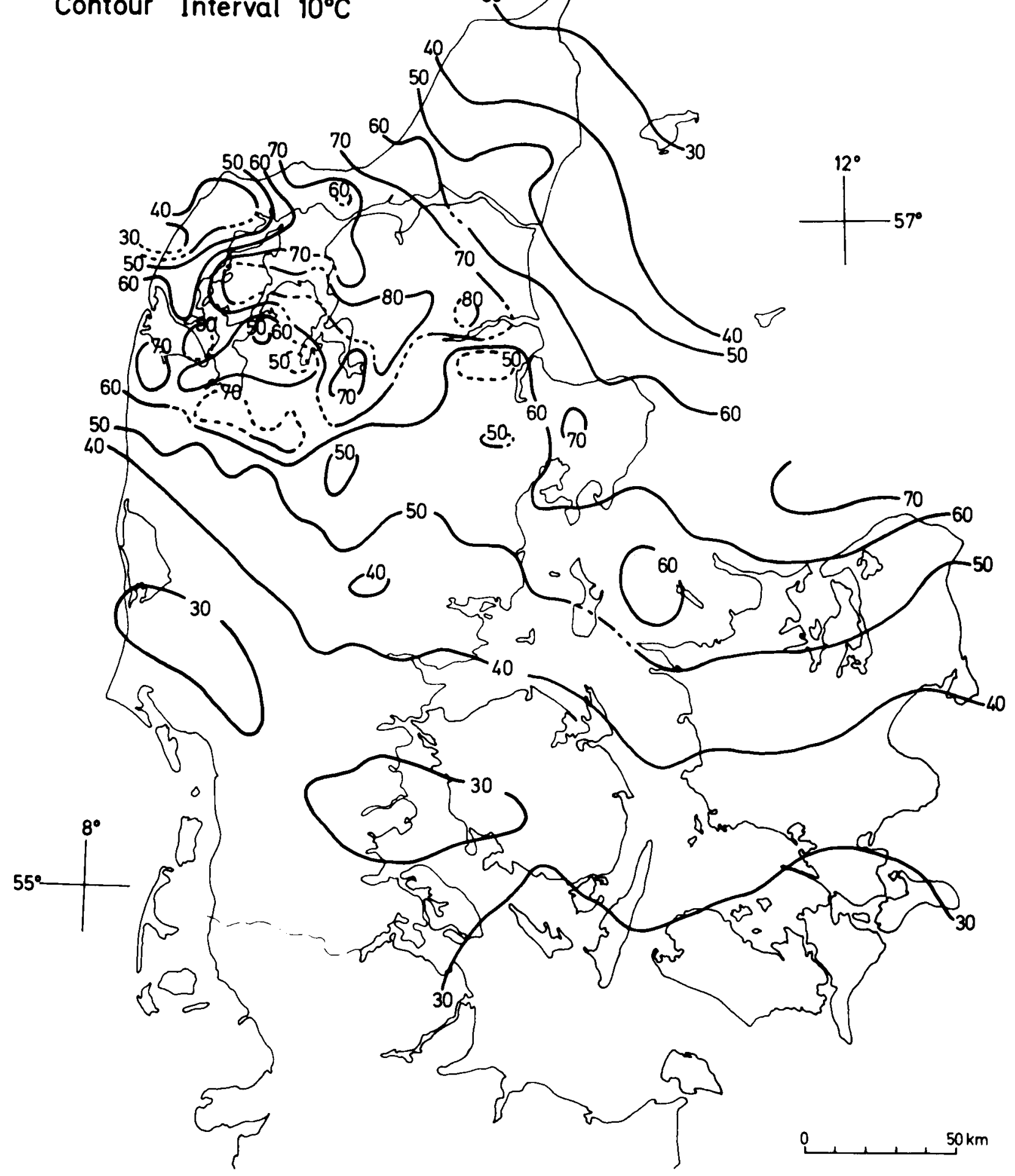

Fig. 25. Isotermer for top trias. Model B. 
Near Top Triassic

Isotherms Model C

Contour Interval $20^{\circ} \mathrm{C}$

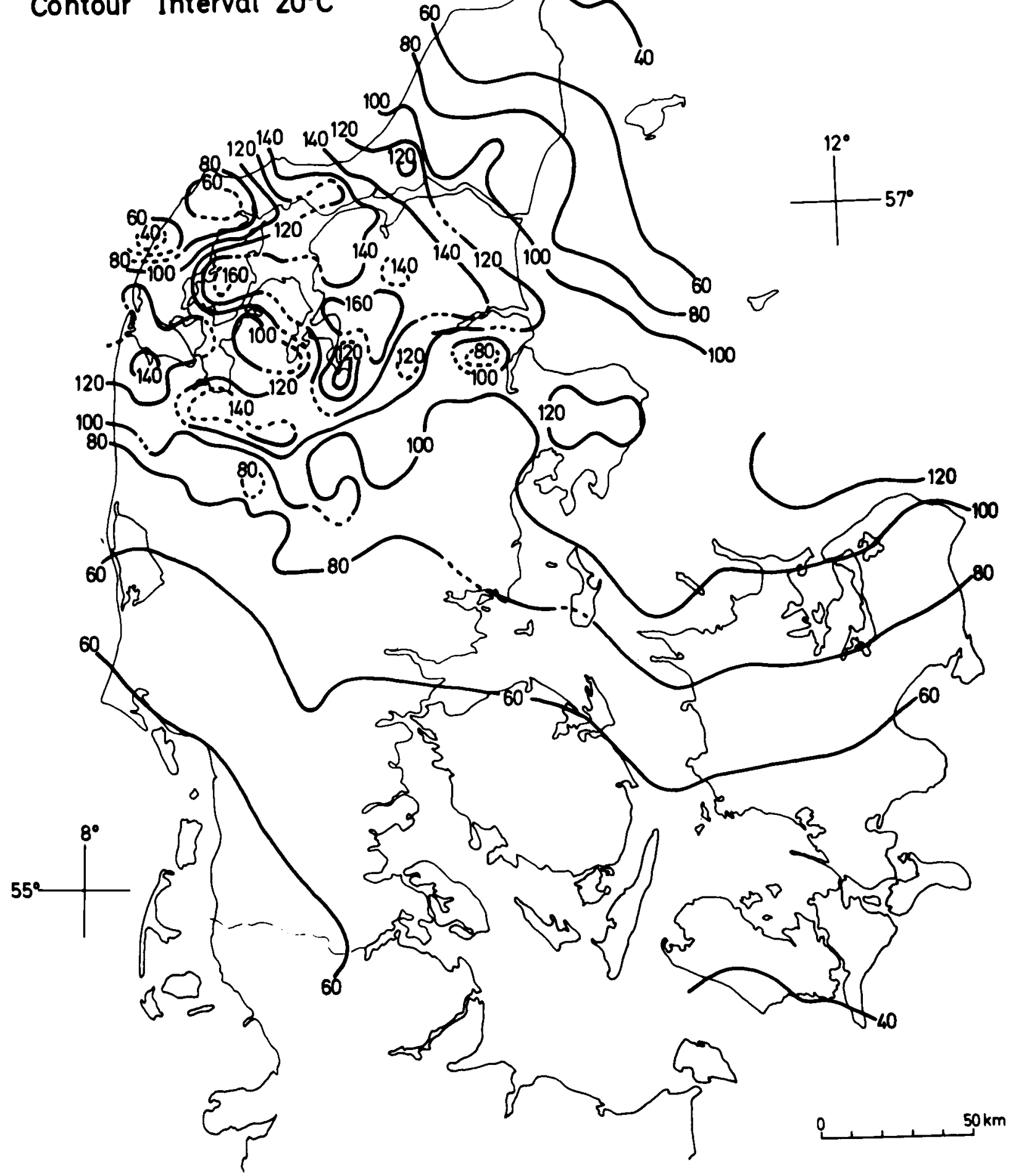

Fig. 26. Isotermer for top trias. Model C. 
Formationen i det nordjyske område har gode geotermiske reservoirkarakterer, samt at den i Nordsjælland udgør et potentielt geotermisk reservoir.

\section{Jura-nedre kridt}

\section{Haldager Sand}

Fig. 27-33. Appendix 1.

Lithostratigrafisk inddeling: Haldager Formation, Haldager Sand (Michelsen 1978).

Geologisk alder: Mellem jura.

Lithologi: Lys olivengrå, fin- til mellemkornet sandsten og siltsten, der kan indeholde glimmer, planterester og kul. Imellem sandstenslagene findes tynde lag af grå til sort, sandholdig lersten. I den sydvestlige del af aflejringsområdet, bassincentralt, hvor lagserien er tynd varierer lithologien fra velsorterede sandlag til dårligt sorterede, lerede og sandede siltstenslag.

Udbredelse, tykkelse og dybde: Haldager Sand findes i størstedelen af Det danske Subbassin. Lagserien har maksimal tykkelse, ca. 150 meter, i den sydøstli- ge del af Vendsyssel og nordøstlige del af Himmerland. Mægtigheder på 25-50 meter forekommer i den centrale og nordøstlige del af Det danske Subbassin, medens lagserien er under 10 meter $i$ den sydlige og sydvestlige del af bassinet. Anselige mægtigheder forekommer lokalt i randsynklinaler omkring saltstrukturer, f.eks. syd for Linde-Vejrum og omkring Tostrup.

I Vendsyssel, i den østlige del af Himmerland og mod Ringkøbing-Fyn Højderyggen, ligger Haldager Sand i dybden 1000-2000 m. I Det danske Subbassins centrale dele er dybden 2000-3000 meter og i enkelte områder endnu dybere. De lokale randsynklinalaflejringer kan være dybtliggende, over 2500 meter.

Porøsitet og permeabilitet: Porøsiteten aftager generelt med dybden. Der er dog en stor spredning i porøsitetsværdierne i intervallet $0-1500 \mathrm{~m}$. Fra 1500 $\mathrm{m}$ til $2500 \mathrm{~m}$ aftager porøsiteten fra ca. $30 \%$ til ca. 20 $\%$. Der findes kun luftpermeabilitetsmålinger fra 3 boringer. Disse varierer fra $2000 \mathrm{mD}$ ved porøsitet på $33 \%$ til $500 \mathrm{mD}$ ved $21 \%$ porøsitet.

Temperatur: Model A isotermerne (fig. 31) vurderes at give et godt grundlag for en regional vurdering. I den nordligste del af Jylland, hvor måleinfor-

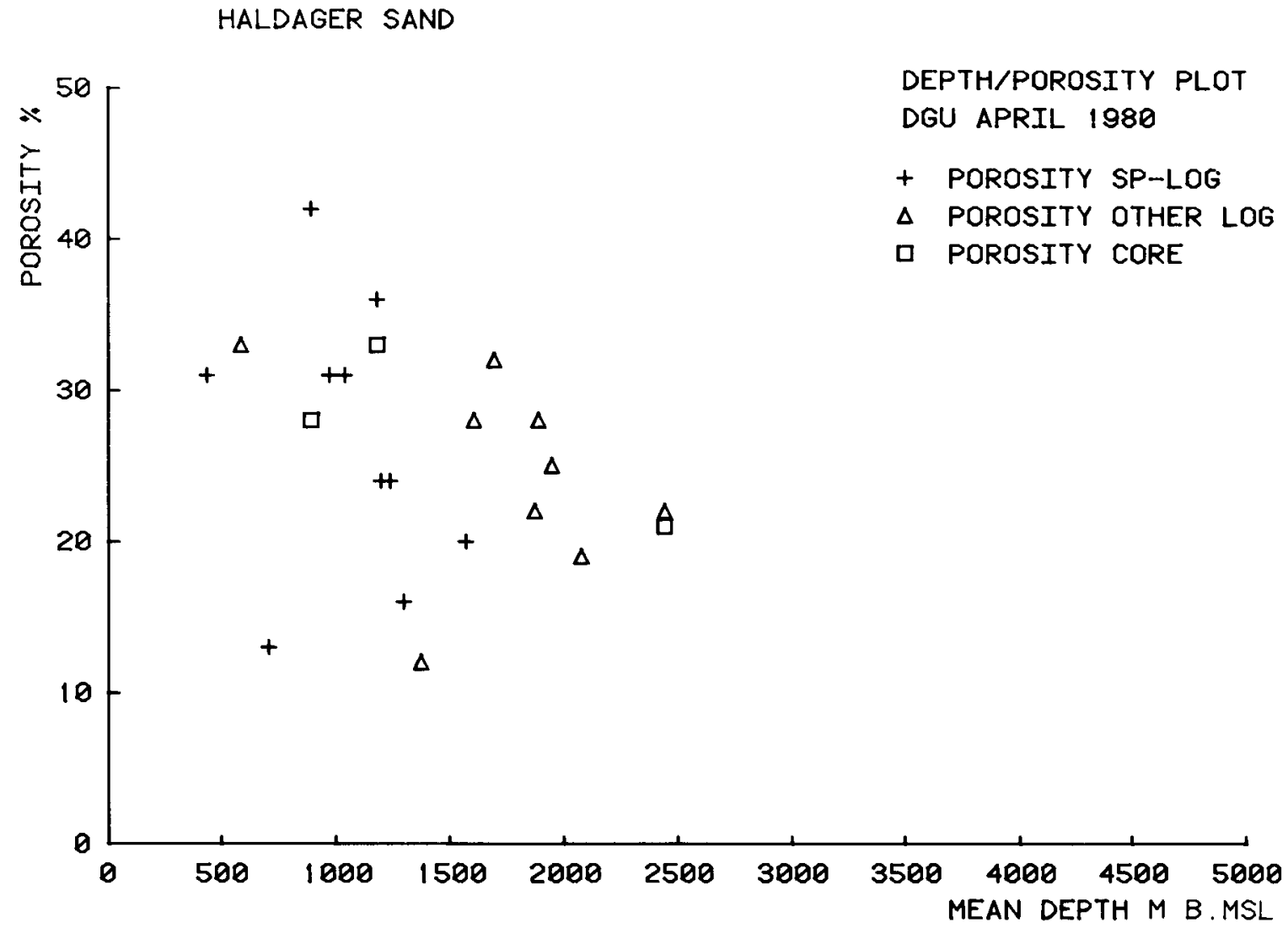

Fig. 27. Porøsitetsværdier for Haldager Sand plottet mod dybden. Det ses, at porøsiteten generelt aftager med dybden. Hvert punkt reprasenterer en boring. Værdierne stammer fra tabellen $\mathbf{i}$ appendix 1. 


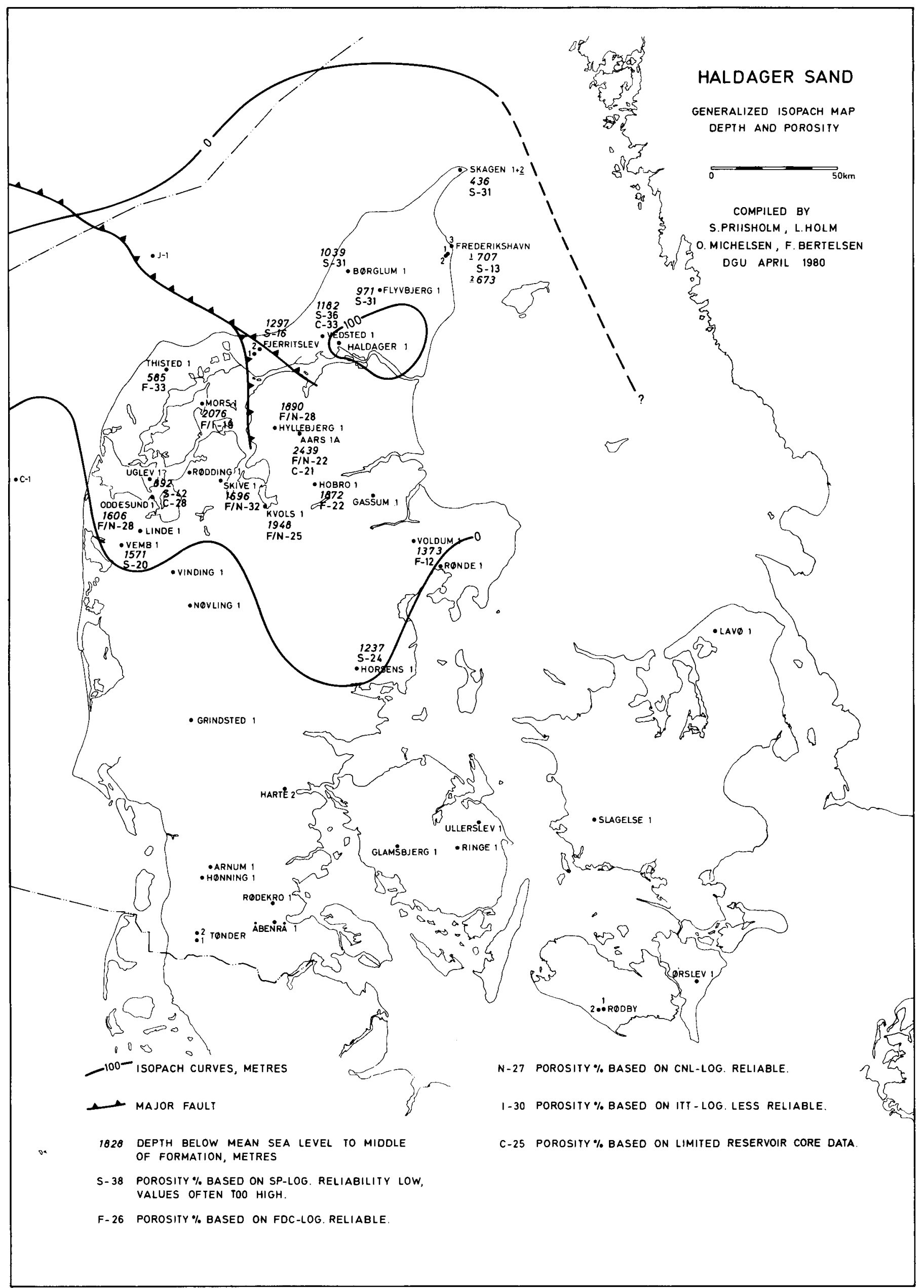

Fig. 28. Haldager Sand. Generaliseret tykkelse, dybde og porøsitet. 


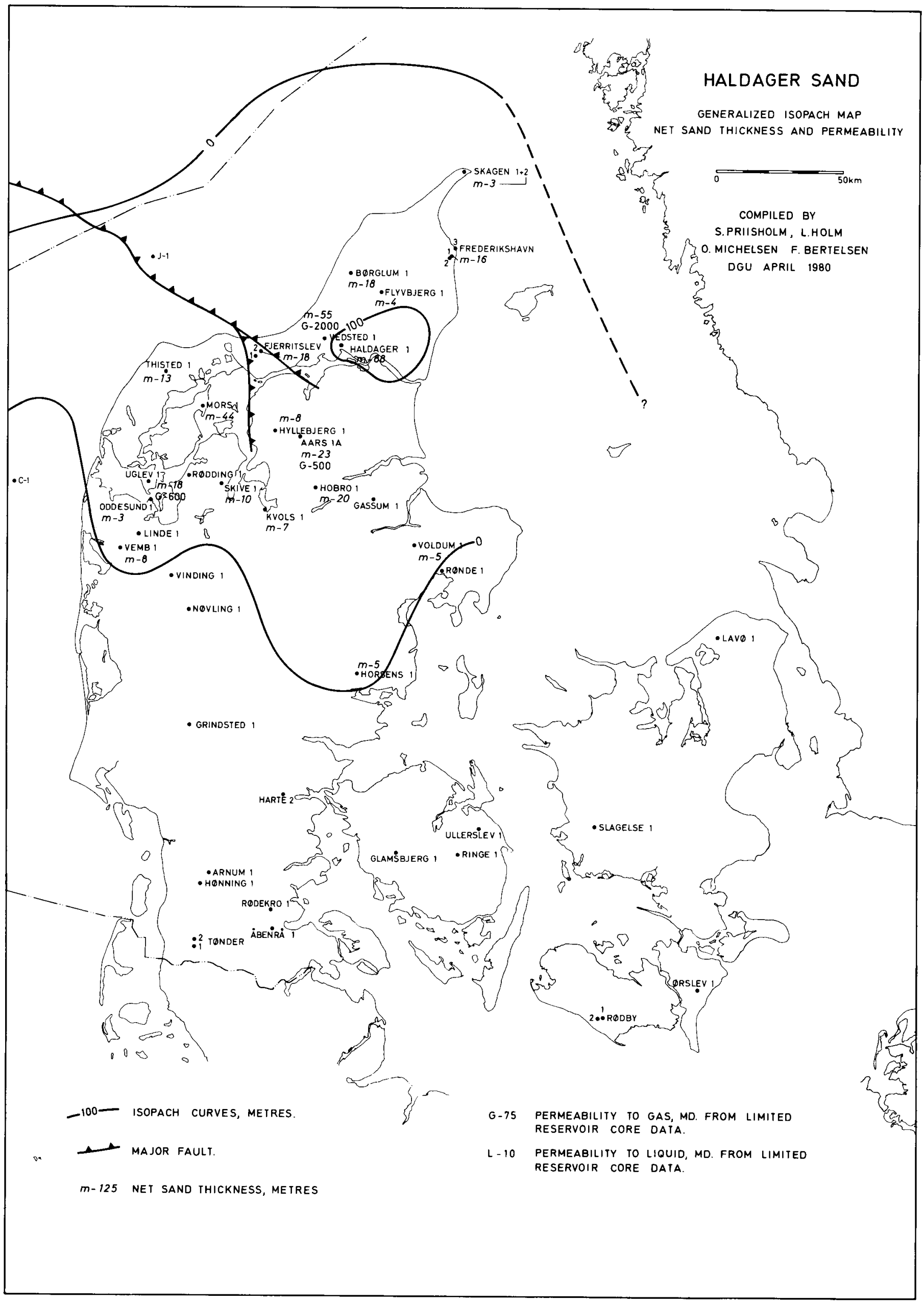

Fig. 29. Haldager Sand. Generaliseret tykkelse, net sand tykkelse og permeabilitet. 


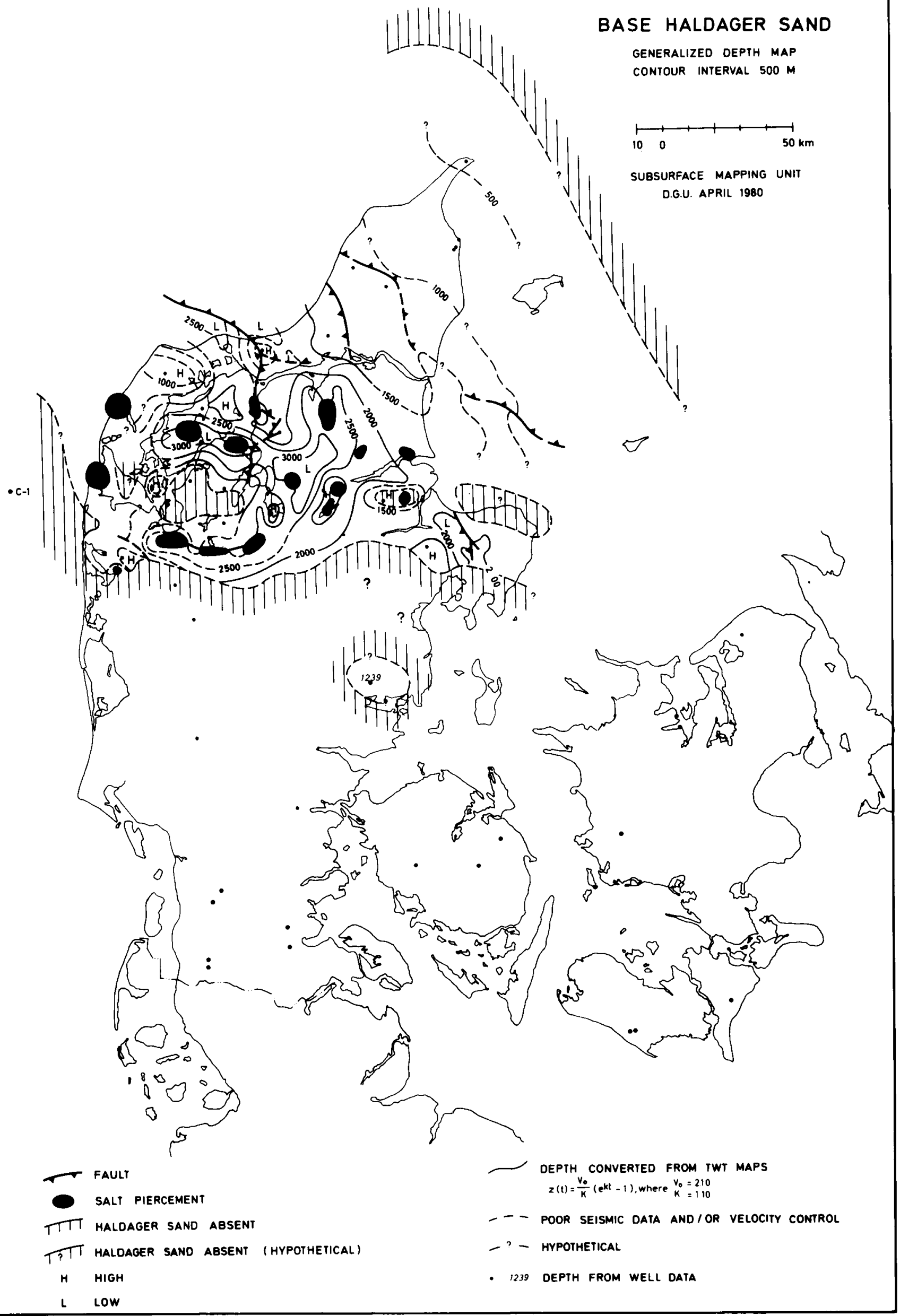

Fig. 30. Generaliseret dybdekort til basis af Haldager Sand. 


\section{Base Haldager Sand} Isotherms Model A Contour Interval $10^{\circ} \mathrm{C}$

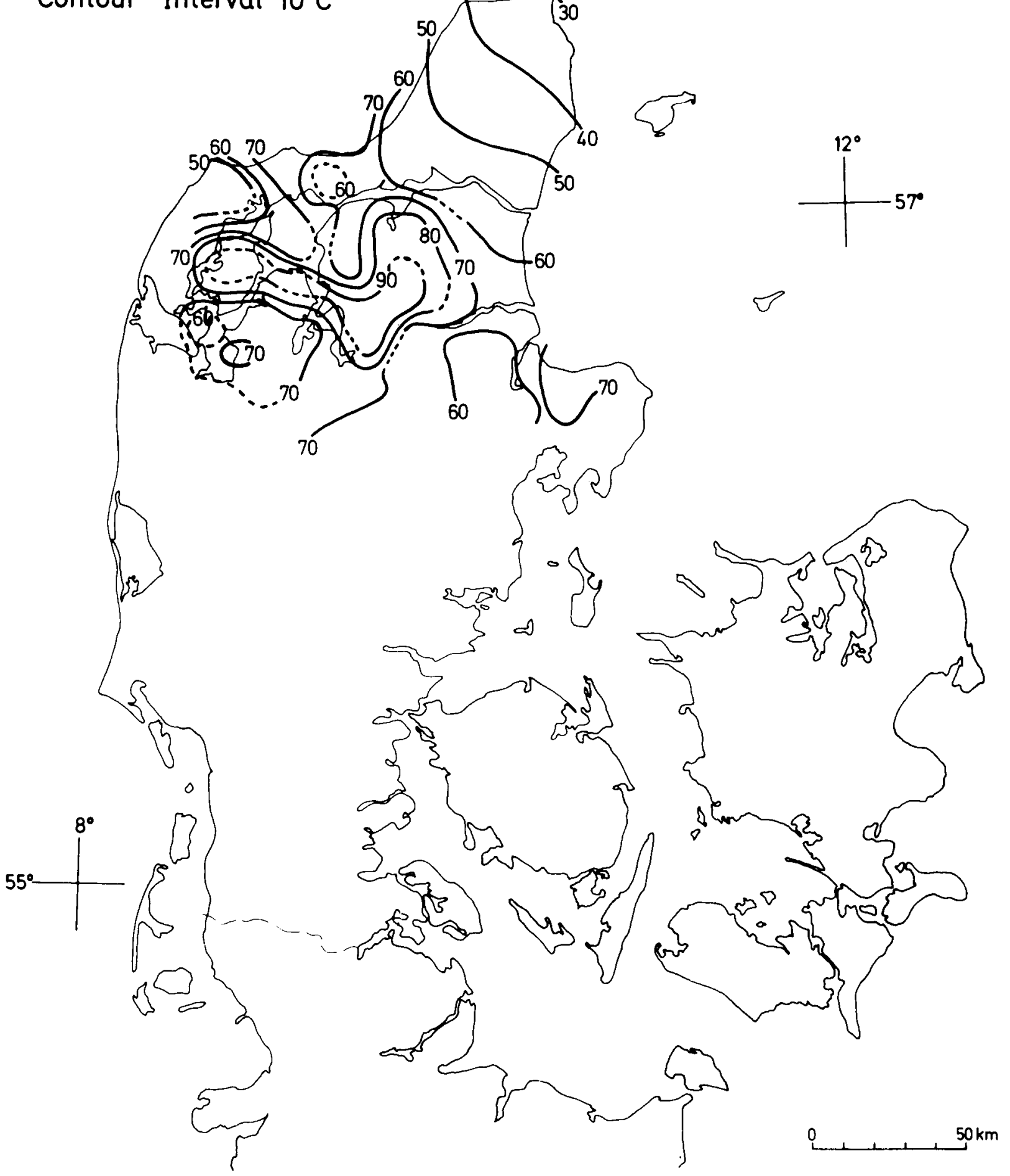

Fig. 31. Isotermer for basis af Haldager Sand. Model A. 


\section{Base Haldager Sand}

\section{Isotherms Model B}

Contour Interval $10^{\circ} \mathrm{C}$

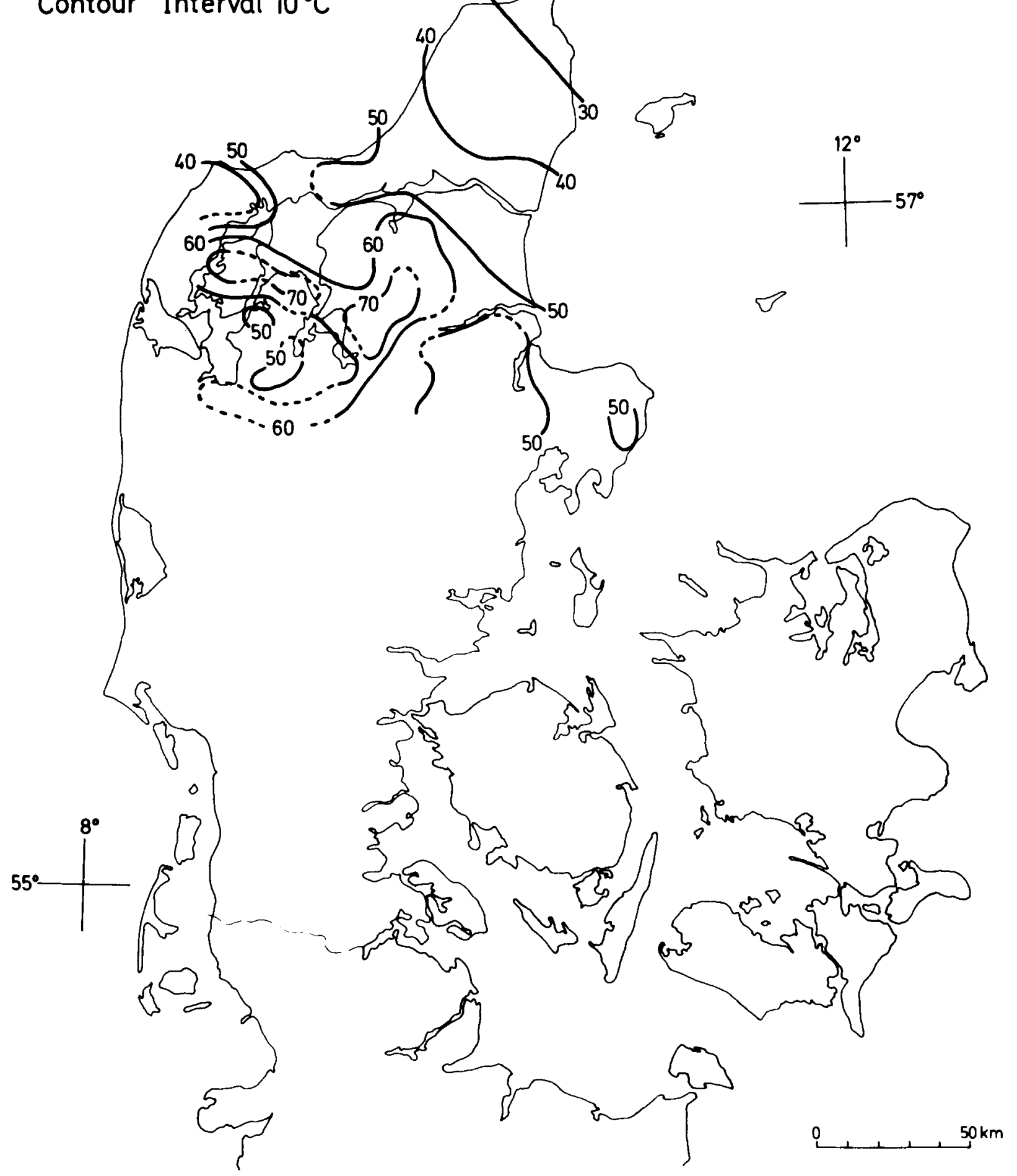

Fig. 32. Isotermer for basis af Haldager Sand. Model B. 
Base Haldager Sand Isotherms Model C

Contour Interval $20^{\circ} \mathrm{C}$

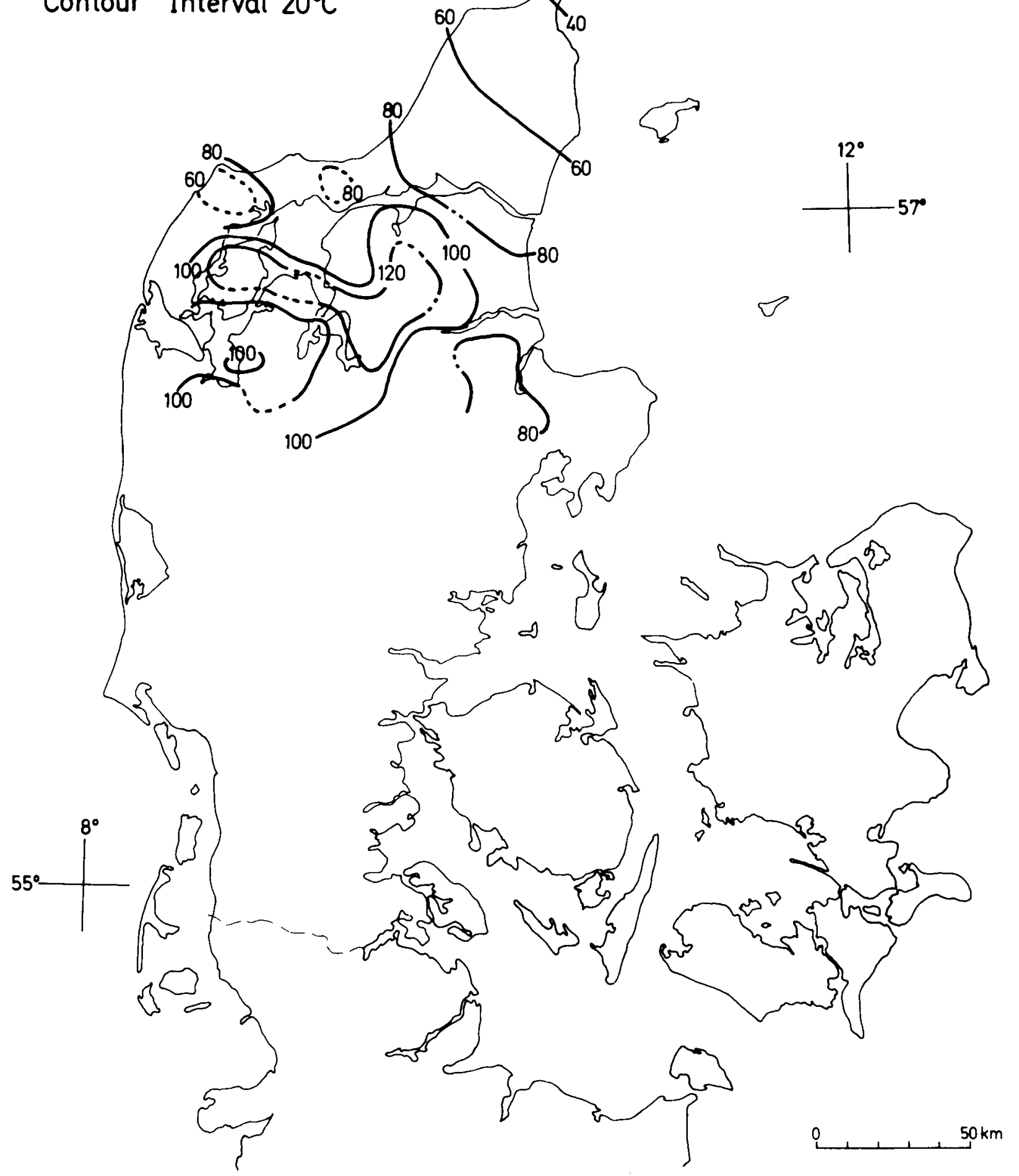

Fig. 33. Isotermer for basis af Haldager Sand. Model C. 
mationen er ringe, kan selv for større områder model B- og evt. C-temperaturer forekomme (fig. $32 \mathrm{og}$ 33). Den typiske reservoirtemperatur i Nordjylland vurderes at ligge mellem $60 \mathrm{og} 80^{\circ} \mathrm{C}$. De generelt højeste temperaturer skønnes at være ca. $80-100^{\circ} \mathrm{C} \mathrm{i}$ Himmerland. Ved konstant dybde og konstant geotermisk flux vil de højeste værdier forekomme, hvor formationen er overlejret af en forholdsvis tynd kalkstensserie og tilsvarende mægtig nedre kridtøvre jura serie.

Sammenfattende bemarkninger: Haldager Sand forventes at have rimeligt gode reservoirkarakterer, ligge i tilpas dybde og dermed have geotermiske muligheder i et bælte midt ned gennem Himmerland, i den nordlige del af Mors samt i lokale randsynklinaler omkring saltstrukturer. I ovennævnte områder findes kun enkelte boringer, hvorfor sandlagens tykkelse og karakter er vanskelig at bedømme. Seismiske tolkninger af randsynklinaldannelserne tyder på væsentlige sandmægtigheder, hvorfor disse områder kan være lovende.

\section{Frederikshavn Member}

Fig. 34-36. Appendix 1.

Lithostratigrafisk inddeling: Bream Formation, Frederikshavn Member (Michelsen 1978).

Geologisk alder: Øvre jura - nedre kridt; kimmeridgien-berriasien.

Lithologi: Siltsten og finkornet sandsten, der veksler med siltholdig lersten. Sandstenen kan være lerholdig, ligesom glimmer, pyrit, mikrolignit og glaukonit forekommer.

Silt-sandindholdet i lerstenen tiltager mod nordøst ligesom mægtigheden og hyppigheden af sandlag tiltager i denne retning.

Udbredelse, tykkelse og dybde: Frederikshavn Member er begrænset til Jylland, nord for Ringkøbing-Fyn Højderyggen.

Lagserien har en tykkelse på 50-150 meter med maksimum på 250 meter i Han Herred. Net sand tykkelsen varierer i Himmerland fra 5-35 meter sti-

\section{FREDERIKSHAVN MEMBER}

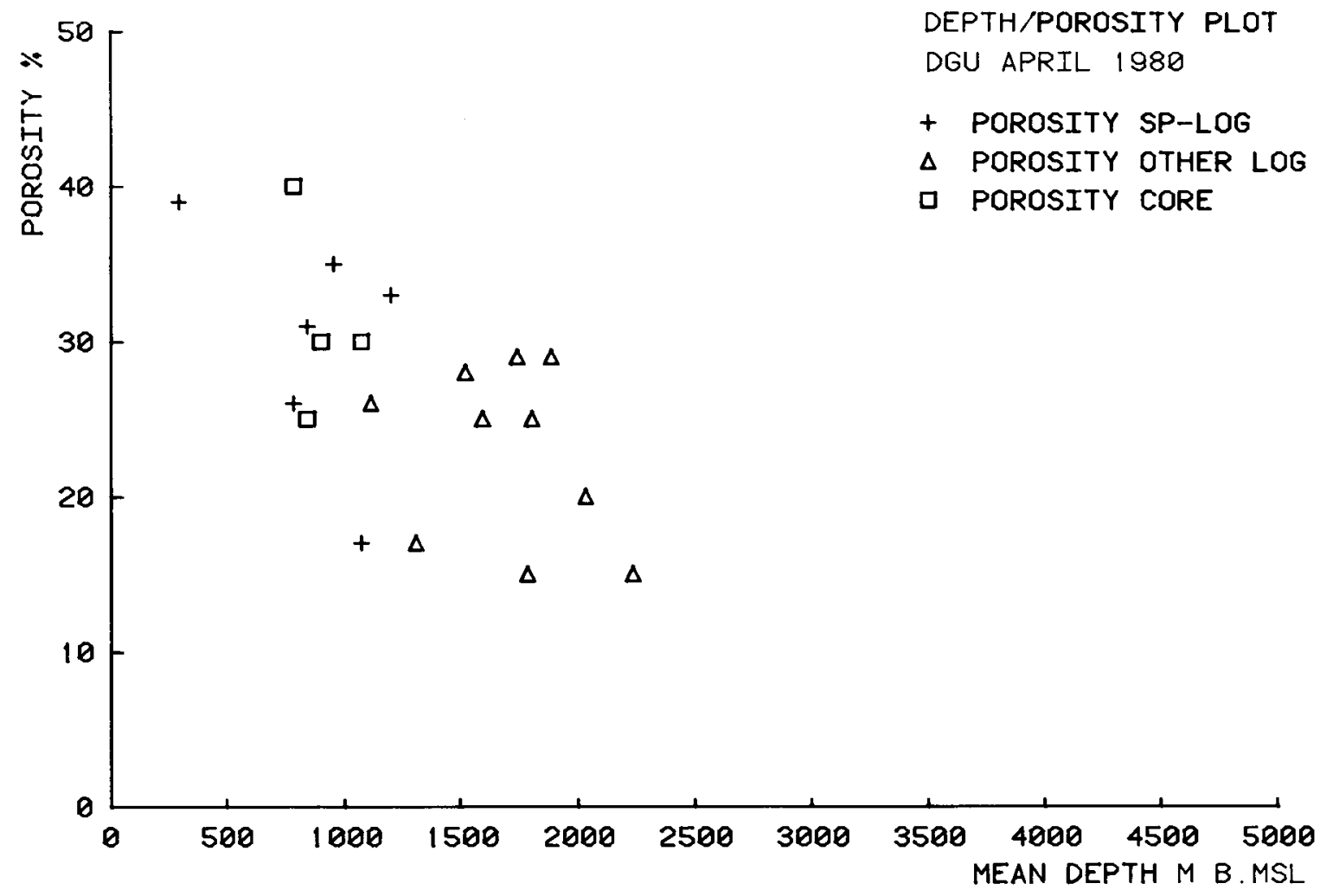

Fig. 34. Porøsitetsværdier for Frederiskhavn Member plottet mod dybden. Det ses, at porøsiteten generelt aftager med dybden. Hvert punkt repræsenterer en boring. Vardierne stammer fra tabellen i appendix 1. 


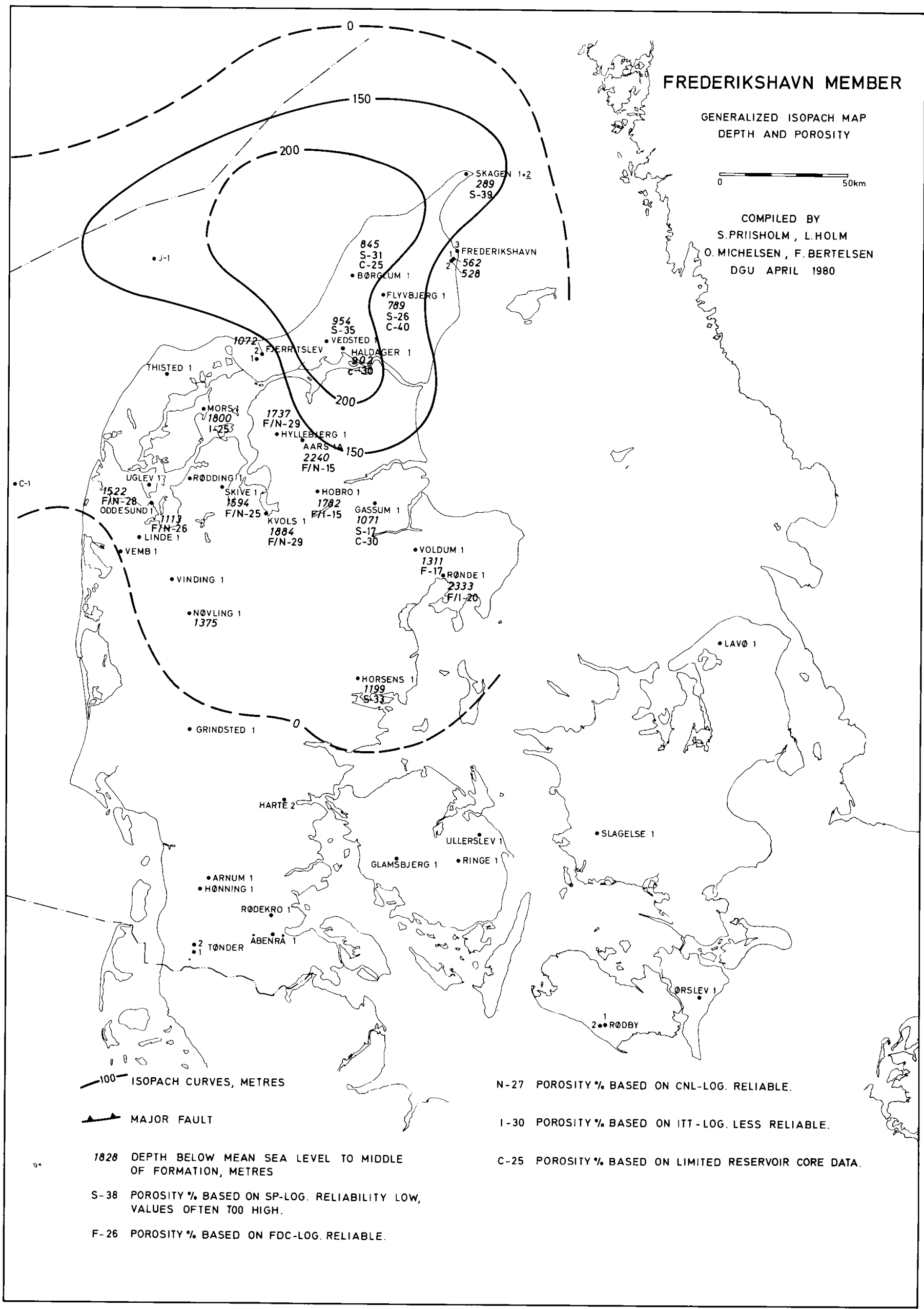

Fig. 35. Frederikshavn Member. Generaliseret tykkelse, dybde og porøsitet. 


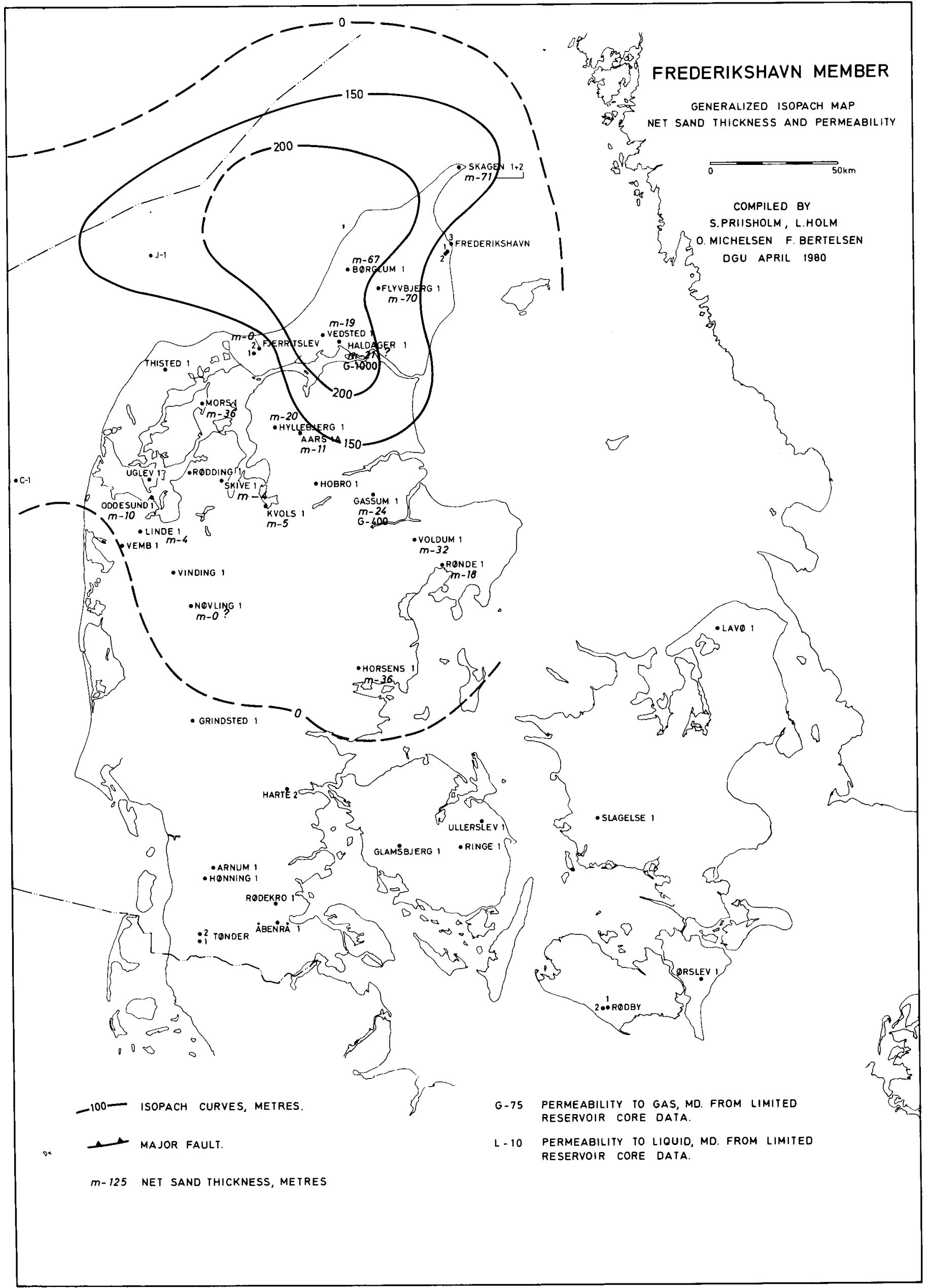

Fig. 36. Frederikshavn Member. Generaliseret tykkelse, net sand tykkelse og permeabilitet. 


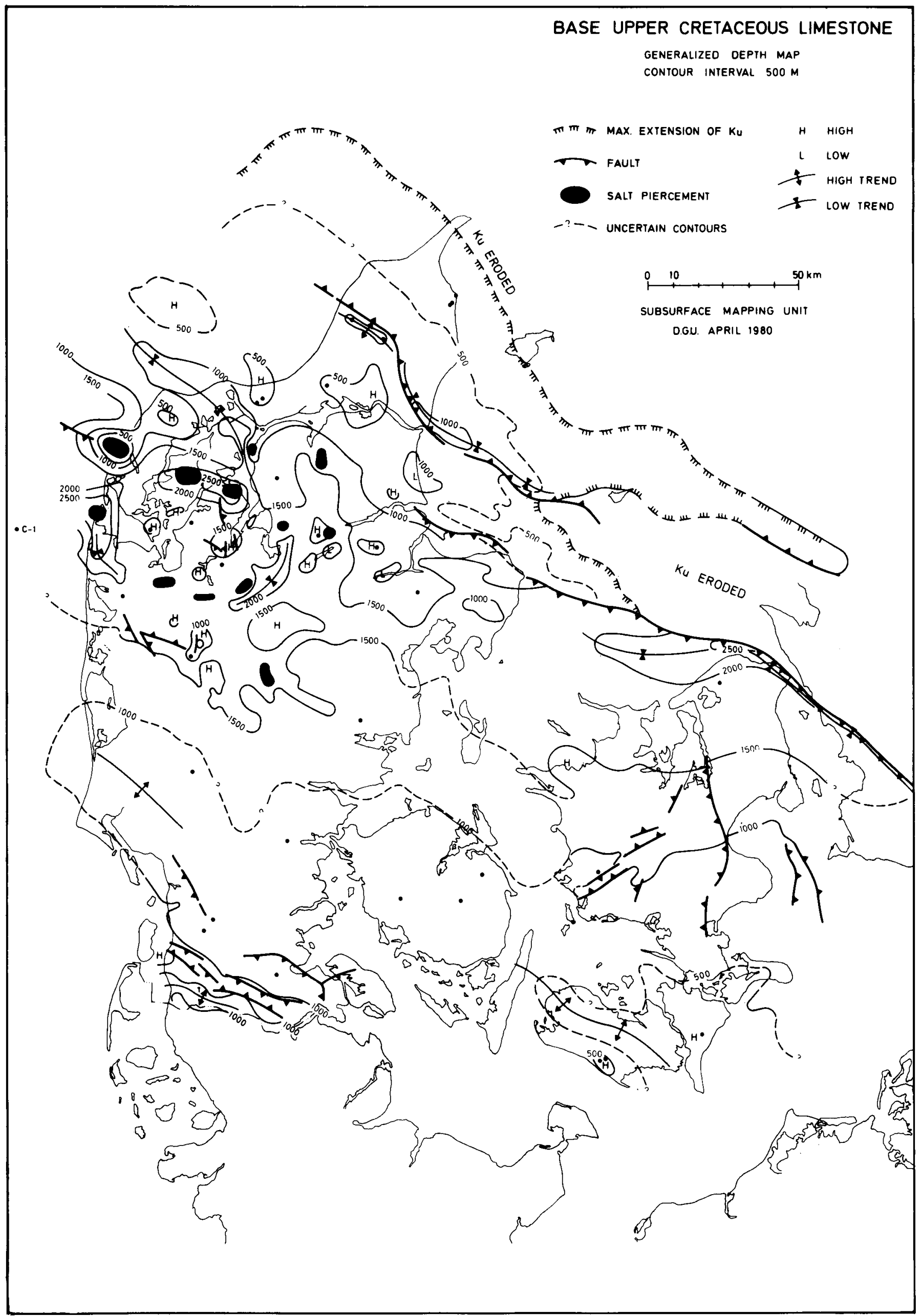

Fig. 37. Generaliseret dybdekort til basis af øvre kridt kalksten. 
Base Upper Cretaceous Limestone Isotherms Model A Contour Interval $10^{\circ} \mathrm{C}$

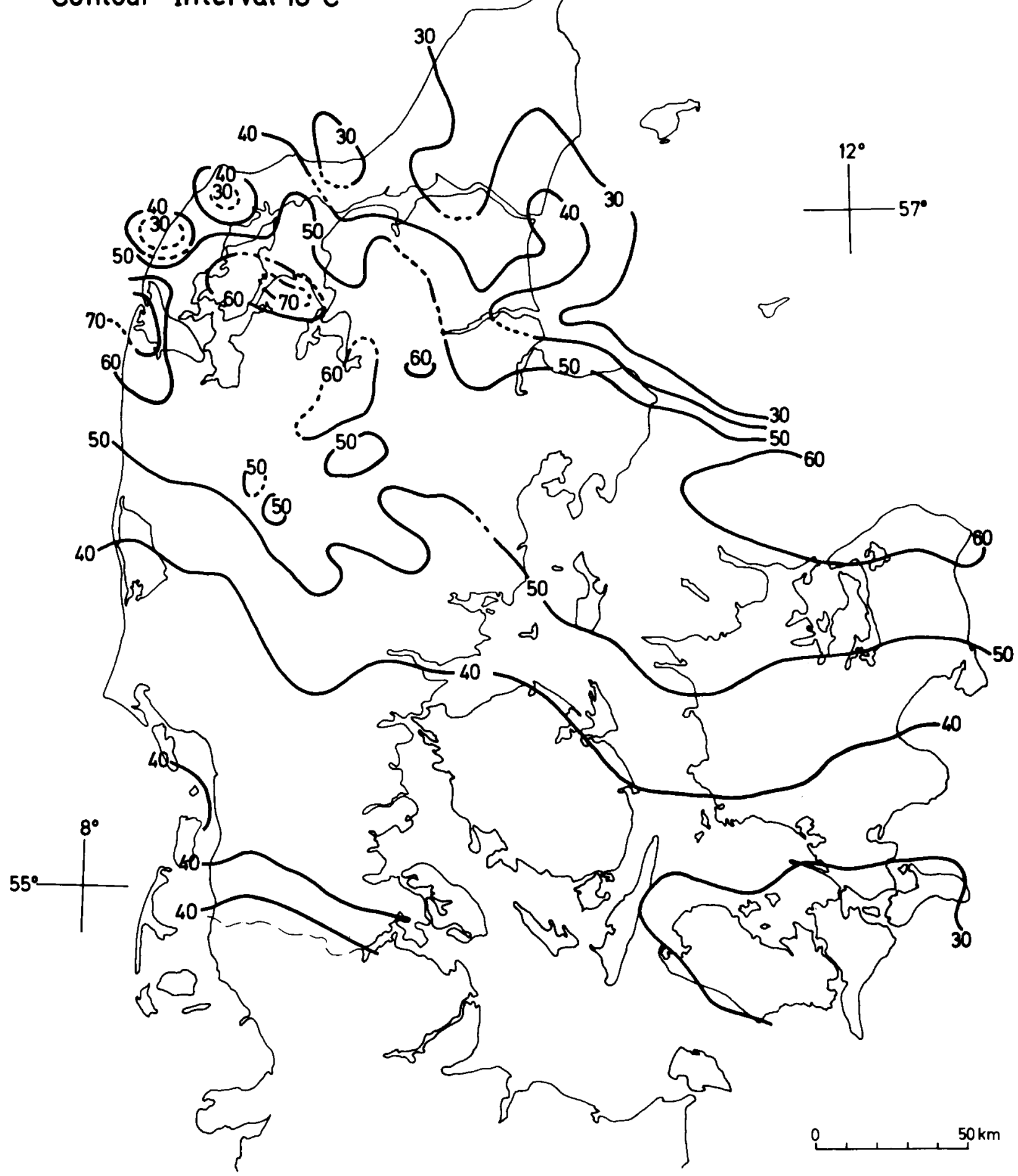

Fig. 38. Isotermer for basis af øvre kridt kalksten. Model A. 
Base Upper Cretaceous Limestone Isotherms Model B

Contour Interval $10^{\circ} \mathrm{C}$

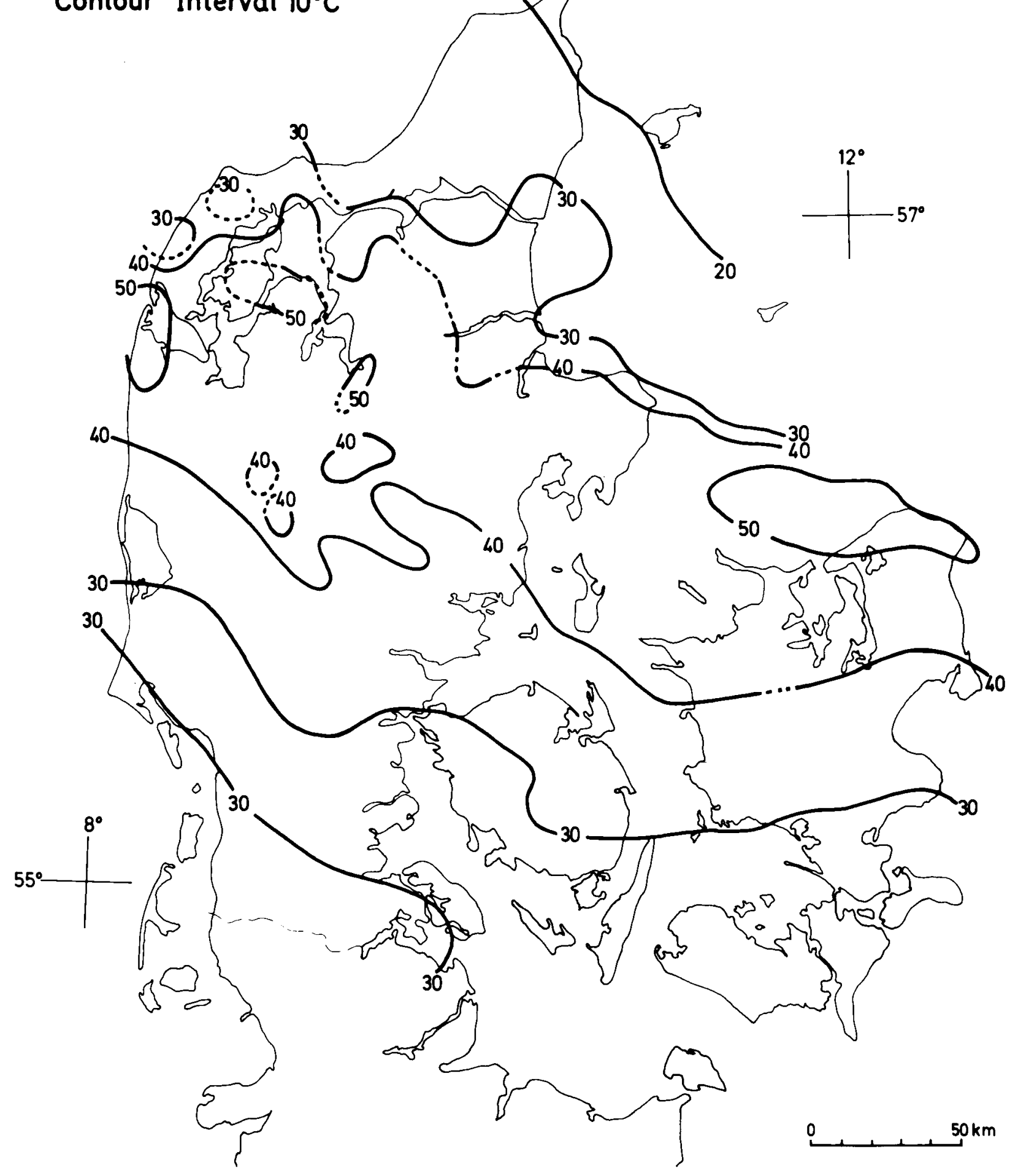

Fig. 39. Isotermer for basis af øvre kridt kalksten. Model B. 


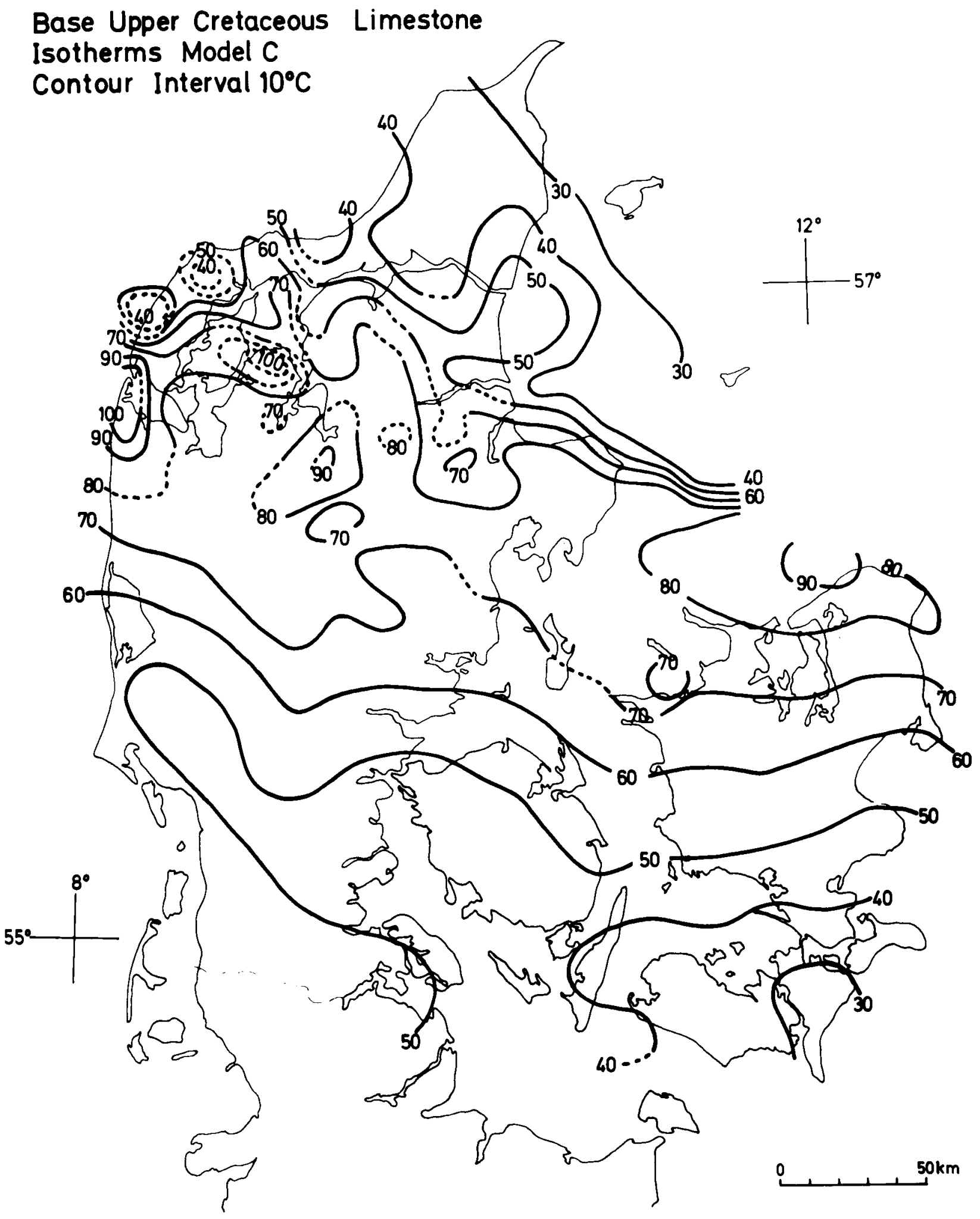

Fig. 40. Isotermer for basis af øvre kridt kalksten. Model C. 
gende til 70 meter i Vendsyssel. Den varierende tykkelse i Himmerland skyldes lokale ændringer i aflejringsmiljøet, delvis forårsaget af tektoniske forstyrrelser. Dybden til top af Frederikshavn Memberet er cirka 1000 meter. Maksimal dybde på lidt over 2000 meter findes centralt i Det danske Subbassin, medens dybden aftager $\mathrm{i}$ Vendsyssel med minimumsdybde på 200 meter ved Skagen.

Porøsitet og permeabilitet: Porøsiteten er relativ god, $25-35 \%$, i 1000 meters dybde, aftagende til $15-20 \%$ i 2000 meter. Det varierende indhold af glaukonit, glimmer og ler nedsætter dog porøsiteten væsentligt i nogle områder.

Permeabiliteten antages at være $500-1000 \mathrm{mD}$ i områder med $25-35 \%$ porøsitet. Glimmer- og lerindhold vil nedsætte permeabiliteten.

Temperatur: Frederikshavn Memberets temperatur kan i de områder, hvor lagserien findes, med god tilnærmelse aflæses på model A-isotermerne for basis af øvre kridt kalksten (fig. 38). Der er størst usikkerhed for områderne i det nordligste Jylland, hvor temperaturer svarende til model B og C (fig. 39 og 40) kan forekomme. I de dybere dele af Subbassinet vurderes temperaturen typisk at vare $50-60^{\circ} \mathrm{C}$, lokalt omkring $70^{\circ} \mathrm{C}$, aftagende til $35-45^{\circ} \mathrm{C}$, hvor formationen findes i dybder omkring $1000 \mathrm{~m}$.

Sammenfattende bemarkninger: Frederikshavn Memberets porøsitet og permeabilitet vurderes som god i dybder mindre end 1000 meter. Under denne dybde aftager værdierne, og samtidig er aflejringstypen her, i Himmerland, karakteriseret ved spredte, tynde sandstenslag af begrænset udbredelse, hvorfor memberets værdi i geotermisk sammenhæng er begrænset.

\section{Hydrokemi}

I Danmark er der udført ca. 50 dybdeboringer på land, de fleste af disse er beliggende i Nordjylland. Boringerne er for størsteparten udført med olieefterforskning for øje, men en del er udført med henblik på at finde kaliforekomster i udnyttelige mængder.

Da der ikke blev fundet olie og gas af økonomisk betydning var der ingen interesse for at foretage prøvepumpninger (drill stem tests) af de forskellige reservoirer. Ved to Suldrup-boringer indsamledes og analyseredes vandprøver $\mathrm{i}$ forbindelse med artesiske udbrud, da boret nåede lag af hovedsagelig gibs og dolomit i salthorsten. Også ved Tønder 1 boringen oplevede man et artesisk udbrud af saltvand, da boret nåede et anhydritlag i zechstein.

Som sagt er drill stem tests kun udført i nogle af olieefterforskningsboringerne, og kemianalyser af det oppumpede saltvand foreligger kun fra en del af disse drill stem tests. Ikke alle af de foreliggende kemianalyser er medtaget, da det oppumpede vand skønnedes at være kraftigt forurenet med boremudder.

Kemianalyserne kan groft opdeles i 2 grupper, den ene repræsenterer formationsvand fra zechstein lagene, den anden formationsvand fra de forskellige sandstensformationer. Geotermisk vand vil sandsynligvis ligge tættest ved sidstnævnte gruppe. Formationsvand fra de forskellige sandstensformationer viser en øget saltholdighed med stigende dybde.

Som en tommelfingerregel øges formationsvandets saltholdighed med dybden på følgende måde: 1000 $\mathrm{m} \sim 10 \%$ salinitet, $2000 \mathrm{~m} \sim 20 \%$ salinitet og 3000 $\mathrm{m} \sim 30 \%$ salinitet.

En tilsvarende relation til dybde kan dog ikke forventes for formationsvand fra zechstein lagene.

En generel viden om det geotermiske vands saltholdighed er imidlertid utilstrækkelig til at bedømme omfanget og arten af korrosion og scaling. Til det formål er det nødvendigt at have et præcist kendskab til formationsvandets surhed, og indhold af opløste ioner og gasser.

\section{Regional reservoirkarakteristik}

På grundlag af ovenstående reservoirbeskrivelser, samt den seismiske kortlægning og analyse af datadækning og -kvalitet kan Danmark opdeles i seks områder med hver sin karakteristik med hensyn til geotermiske reservoiregenskaber. Som ramme for inddelingen benyttes dybdeintervallet 2000 til 3000 $\mathrm{m}$, idet temperaturen kan være for lav over $2000 \mathrm{~m}$, og diagenesen (hærdningen) kan være for fremskreden under $3000 \mathrm{~m}$. Uanset alle formationer ikke har en mineralogisk sammensætning, der bevirker diagenetiske ændringer af samme grad under samme vilkår, og uanset disse faktores indflydelse endnu ikke er grundigt undersøgt, er $3000 \mathrm{~m}$ her brugt som en nedre grænse for vurderingen.

Til brug for denne sammenfattende konklusion er der fra bl.a. dybdekortene uddraget hvilke formationer, der forekommer i dette dybdeinterval. Disse er i generaliseret form indtegnet på kortet fig. 41. Sammenholdt med analyserne af reservoiregenskaberne er der på kortet fig. 43 foretaget en opdeling og en 
klassifikation i seks områder. Denne klassificering sigter på at give et samlet indtryk af hvilke geologiske lag (formationer), der eventuelt kan udnyttes i de forskellige dele af landet, og af hvilken form og grad af undersøgelser, der er nødvendig for kommende efterforskning af geotermisk energi.

Model A isotermerne for $2000 \mathrm{og} 3000 \mathrm{~m}$ fremgår af fig. 42 og 44. For områder hvor basis af trias ligger over disse niveauer er der beregningsmæssigt for de ældre formationer anvendt samme termiske parametre som for trias lagene (lag 7, tabel 2). I de centrale dele af Det danske Subbassin er der regionalt fundet overensstemmelse inden for $\pm 5-10^{\circ} \mathrm{C}$ mellem disse modelværdier og målte temperaturer. Uden for dette område og lokalt inden for området må temperaturen svarende til model B og evt. C medtages i vurderingen (se teksten til fig. 42 og 44).

Område $A$ er udskilt som det område, hvor Gassum Formationen vil være hovedobjektet. Haldager Sand ligger dog i begrænsede dele også inden for det omtalte dybdeinterval. Mod syd i Jylland er afgrænsningen lagt, hvor formationens net sand tykkelse er mindre end $50 \mathrm{~m}$, og mod nordøst hvor formationen menes at overlejre Skagerrak Formationen direkte. På Sjælland er dybdekonturerne fulgt.

Jylland: Som det fremgår af tekst og tabeller forventes Gassum Formationens reservoirkarakterer at være af varierende værdi, men generelt set gode. Den nordøstlige del af Område $\mathrm{A}$ menes at have de bedste reservoiregenskaber. I en del af dette delområde ligger Haldager Sand tillige under 2000 m grænsen og kan som sådan udgøre et alternativt eller supplerende objekt.

Sjælland: Gassum Formationen er indenfor området kun kendt fra boringen Lavø 1, men grundet den regionale beliggenhed forventes der rimelig gode reservoirkarakterer.

Område $B$ er udskilt som et område, hvor Skagerrak Formationen vil være hovedobjekt. Sydligst ligger tillige Gassum Formationen under 2000 m grænsen og overlejrer Skagerrak Formationen direkte. Aflejringernes reservoirkarakterer er meget dårligt kendte, idet kun to boringer har anboret Skagerrak Formationen, mens de øvrige er standset i Gassum Formationen. Den seismiske dækning og kvalitet heraf udelukker en forsvarlig kortlægning.

Den regionale placering gør, at der må forventes forekomster af relativt tykke sandstenslag med varierende reservoirregenskaber alt efter aflejringsmiljø, - formodentlig bedst i den sydlige del af området.
Områdets nordlige grænse er muligvis valgt for langt mod nord, idet den noget usikre seismiske indikation af $2000 \mathrm{~m}$ dybdekonturen for top præ øvre perm er fulgt.

Område C er på kortet fig. 43 mærket med "B" eller "?T", idet sidstnævnte er udskilt som delområde. Område C omfatter de dele af landet, hvor ældre trias aflejringer, Tønder og Bunter Sandsten Formationerne, kan komme på tale som efterforskningsobjekt for geotermisk energi. Gassum Formationen ligger ikke dybt nok og/eller har for ringe reservoiregenskaber. Området omfatter en del af Sjælland, og i Jylland området mellem område A og RingkøbingFyn Højderyggen, samt en del småområder, der grundet den komplicerede strukturelle opbygning findes indenfor område $\mathrm{A}$.

Sjælland: Aflejringerne kendes kun fra den seismiske kortlægning, som er baseret på materiale af varierende kvalitet. Grundet den ringe afstand til Den fennoskandiske Randzone, hvor Bunter Sandsten er kendt (fra Skåne), er det berettiget at formode forekomst af rimelige gode reservoiregenskaber. Længst mod nord i området ligger Bunter Sandsten Formationen dybere end $3000 \mathrm{~m}$, men baseret på analogislutninger fra bl.a. Slagelse boringen forventes sandlag ækvivalente med Tønder Formationen at forekomme, men med ukendt net sand tykkelse.

Jylland: I området syd for område A kendes ældre trias aflejringer kun fra boringerne Rønde 1 og Nøvling 1. Den seismiske dækning er forholdsvis ringe og kortlægningen kan kun foretages i begrænset omfang. Bunter Sandsten Formationen findes mod syd i det omtalte dybdeinterval, men dykker mod nord under $3000 \mathrm{~m}$ samtidig med at sandlagenes samlede tykkelse tiltager. Også kornstørrelsen forventes at tiltage. I den nordlige del af området, mærket med "?T", forventes Tønder Formationen at være et muligt efterforskningsobjekt.

De småområder inden for område A som på kortet er markeret som område C er primært karakteriseret ved at Gassum Formationen ikke ligger indenfor dybdeintervallet. Kendskabet til de ældre trias aflejringer i disse småområder er meget ringe og kan ikke kortlægges med nuværende seismiske materiale. Grundet den almindelige regionalgeologiske opfattelse vil Tønder Formationen og, i begrænsede områder, også Bunter Sandsten Formationen ligge i passende dybde og have rimelig gode reservoiregenskaber.

Såvel seismiske som geologiske undersøgelser af de to formationer i område "C" er påkrævet.

Fig. 41. Kort over reservoirformationer, der forekommer i dybdeintervallet $2000-3000 \mathrm{~m}$ 


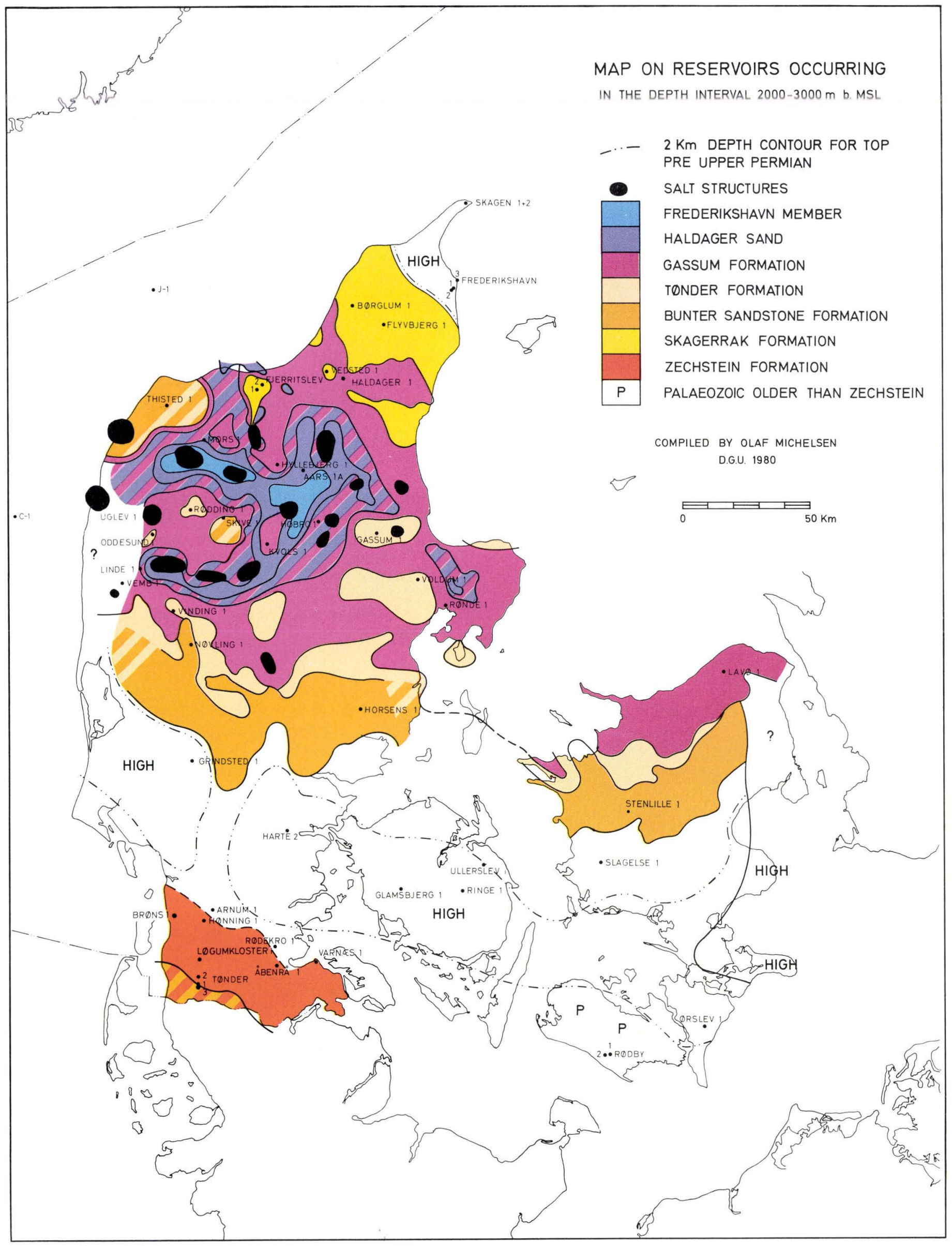


Depth: $2000 \mathrm{~m}$

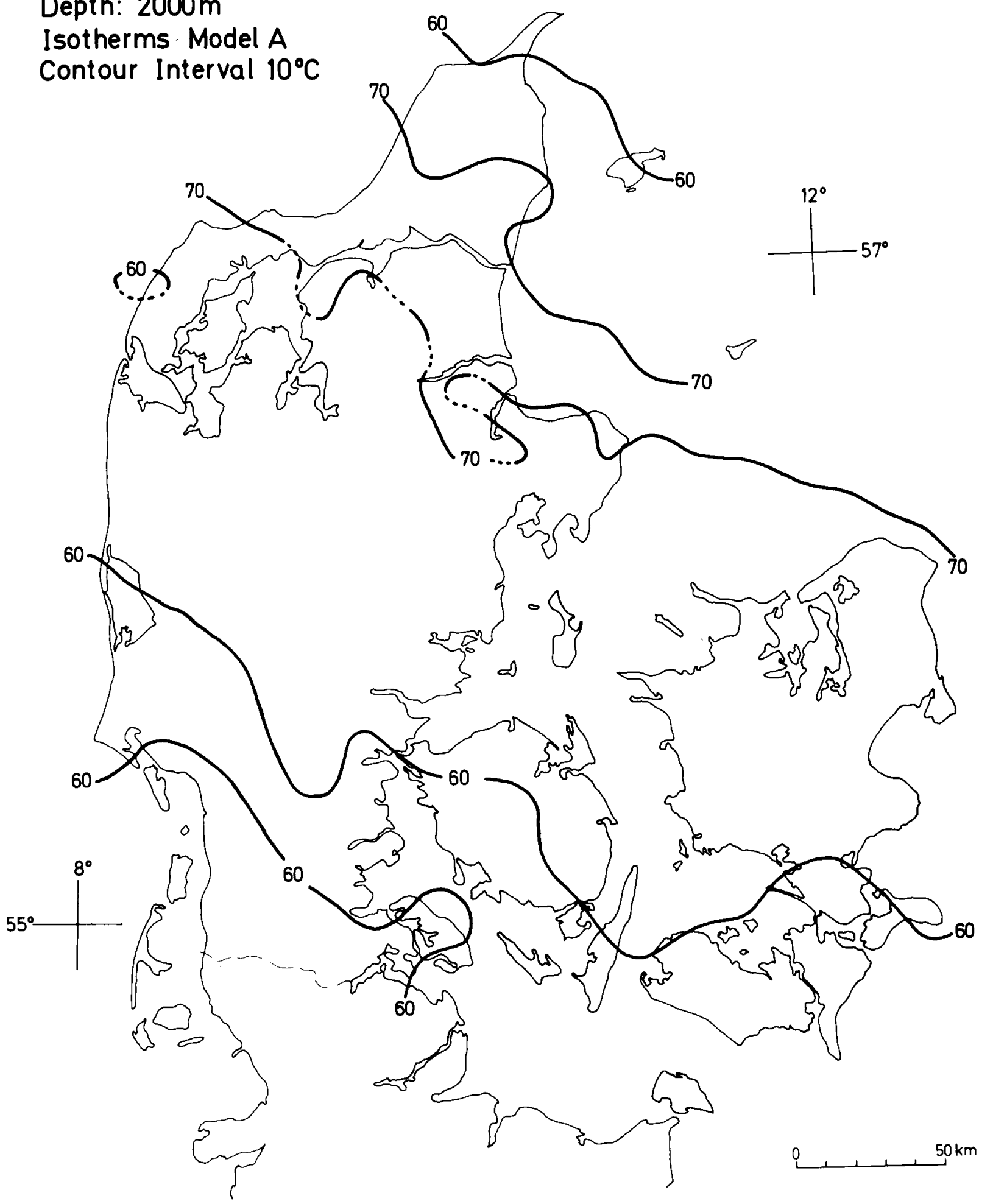

Fig. 42. Isotermer for 2000 m's dybde. Model A.

Fig. 43. Regional udbredelse af mulige geotermiske reservoirer i dybdeintervallet $2000-3000 \mathrm{~m}$. (Side 63). 


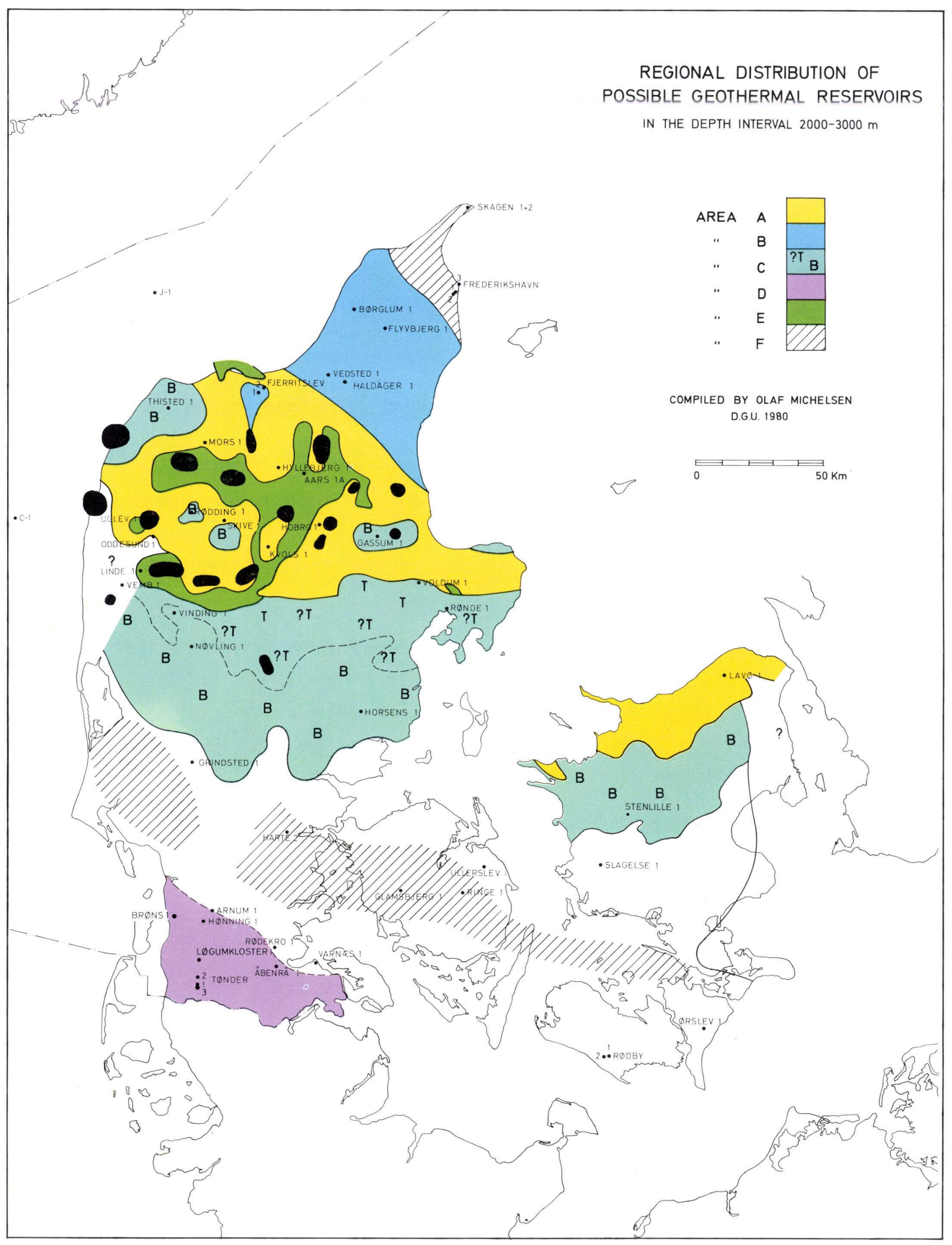


Depth: $3000 \mathrm{~m}$

Isotherms Model A

Contour Interval $10^{\circ} \mathrm{C}$

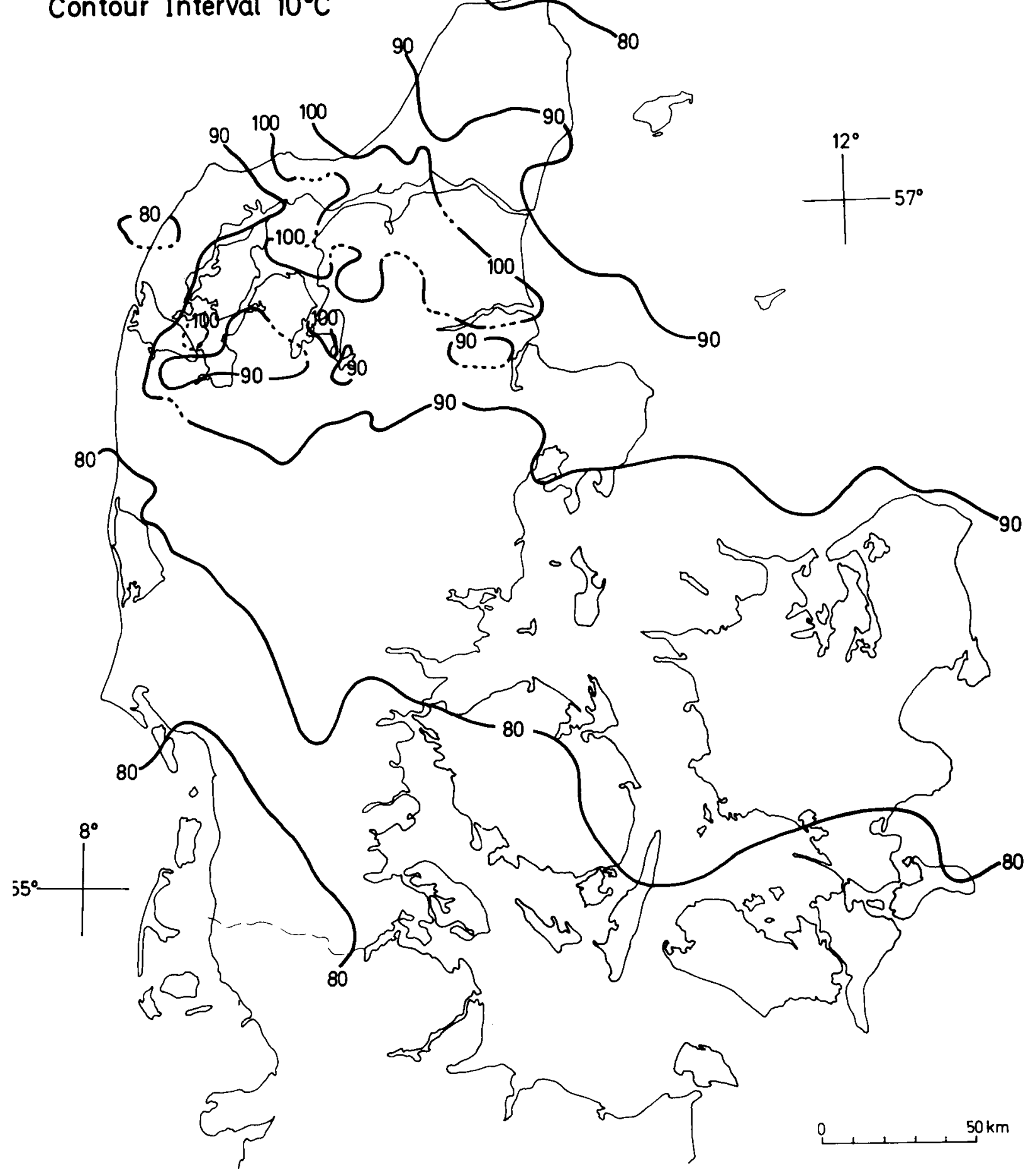

Fig. 44. Isotermer for 3000 m's dybde. Model A. 
Område $D$ er begrænset til det sydligste Jylland. Det er udskilt på grundlag af forekomst af zechstein kalksten, og i det sydvestligste hjørne tillige af Bunter Sandsten Formationen.

Kendskabet til formationerne er begrænset, men det skønnes at en nøjere efterforskning af reservoiregenskaberne er rimelig og nødvendig.

Område $E$ er karakteriseret ved at Gassum Formationen ligger dybere end $3000 \mathrm{~m}$ og ved at lagene er stærkt forstyrrede af saltbevægelser (diapirdannelse). Inden for dele af området ligger Haldager Sand og Frederikshavn Member i det omtalte dybdeinterval. Begge lagserier forventes generelt at have begrænset gode reservoiregenskaber, idet Haldager Sand ofte er tynd (ringe mægtighed) og Frederikshavn Member er lerholdig. Området må ikke betragtes som en homogen enhed med hensyn til reservoiregenskaber, men som et område inden for hvilket en af de to formationer eller begge rent lokalt vil kunne udnyttes med udbytte. Som en generel oversigt kan området deles i tre dele.

I den nordøstlige del formodes begge formationer at have de bedste reservoiregenskaber. Centralt $i$ dette område ligger Haldager Sand under $3000 \mathrm{~m}$ og den samlede mægtighed af sandlagene i Frederikshavn Member er ukendt, men formodet lille.

I den nordvestlige del forventes Frederikshavn Member at være præget af ler, mens Haldager Sand kan have en ekstraordinær tykkelse i randsynklinalerne omkring saltstrukturerne.

I den sydvestlige del findes der indikationer på at Haldager Sand kan have gode reservoiregenskaber. Regionalt set er sandserien tynd, men det vides fra seismiske undersøgelser, at der forekommer betydelige fortykkelser i enkelte randsynklinaler.

Område $F$ angiver områder uden muligheder for geotermisk indvinding fra sedimentære aflejringer, idet grundfjeldet ligger for højt. Signaturen er angivet i to regioner: nordligste Vendsyssel og Ringkøbing-Fyn Højderyggen. I den forbindelse er det kun relevant at omtale sidstnævnte område nærmere.

Langs flankerne af Ringkøbing-Fyn Højderyggen forekommer der palæozoiske aflejringer med forholdsvis ringe reservoiregenskaber. Således kendes kambrisk kvartsitisk sandsten på Sjælland, karbon kalksten på Falster og rotliegendes sandsten på bl.a. Falster og Lolland.

Ovenstående opdeling af landet i seks områder med generaliserede geotermiske reservoiregenskaber skal ses som et forsøg på at skabe overblik over den viden der er etableret i nærværende projekt. Område A er det bedst kendte og må generelt betragtes som et gunstigt område. Område $\mathrm{B}$ og $\mathrm{C}$ forventes ligeledes at være positive $\mathrm{i}$ begrænsede dele, men yderligere undersøgelser, evt. nye boringer og ny seismik, vil være påkrævet.

\section{Vurdering af reserverne}

På grundlag af de geologiske og geofysiske undersøgelser er der foretaget en vurdering af de geotermiske reserver i Danmark. Formålet med vurderingen er, at tilvejebringe et skøn over hvor stor en del af de estimerede ressourcer, der ud fra et energimæssigt synspunkt kan udnyttes. Der tages således ikke hensyn til økonomiske og afsætningsmæssige forhold $\mathrm{i}$ undersøgelsen; dog viser det sig uundgåeligt at inddrage en simpel økonomisk analyse i vurderingen.

I vurderingen er medtaget områderne $\mathrm{A}, \mathrm{B}$ og $\mathrm{C}$, der anses som de geotermisk mest positive områder. Selv om områderne $\mathrm{B}$ og $\mathrm{C}$ kun forventes at have positive reservoiregenskaber i begrænsede dele, er de i vurderingen medtaget i deres fulde udstrækning. Til gengæld er områderne $\mathrm{D}, \mathrm{E}$ og $\mathrm{F}$ overhovedet ikke inddraget, selv om der lokalt i disse områder kan være gode reservoiregenskaber. Område $\mathrm{C}$ er her inddelt i to områder, $\mathrm{C} 1$ og $\mathrm{C} 2$. Vurderingen omfatter således ialt 4 områder: A, B, C1 og C2 som vist på fig. 45.

Inden for hvert af områderne regnes reservoiregenskaberne konstante. De anvendte værdier er tábelleret i tabel 4. På grund af den store usikkerhed med hensyn til beregning af transmissiviteten er der angivet to (lige sandsynlige) værdier for væskepermeabiliteten.

Vurderingen er foretaget ved dels at bestemme det totale energiindhold $i$ reservoirerne og dels ved at beregne hvor stor del af denne energi, der netto kan udnyttes under forudsætning af, at udvindingen foregår ved hjælp af enkelte anlæg med én produktionsboring og én injektionsboring. Det er endvidere antaget, at energien anvendes til fjernvarme, hvor temperaturkonverteringen mellem geotermi- og fjernvarmekredsløbet foregår ved hjælp af varmepumper.

Anlæggenes levetid er fastsat til 25 år, og fjernvarmeeffekten for et enkelt anlæg er bestemt som den økonomisk optimale værdi fundet ud fra en simpel økonomisk analyse.

For at undersøge indflydelsen af de i beregningerne indgående parametres størrelser, er der foretaget en sensitivitetsanalyse for et enkelt tilfælde. Heraf viser det sig, at størrelsen af reservoirets ydeevne og af de økonomiske data praktisk taget ingen indflydelse har på størrelsen af udnyttelsesgraden, dvs. på 


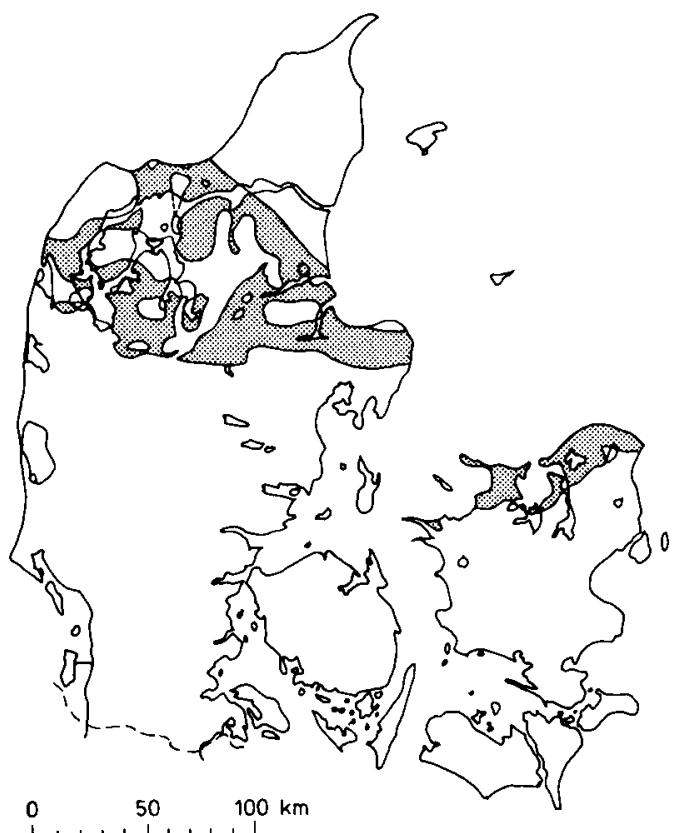

Område A

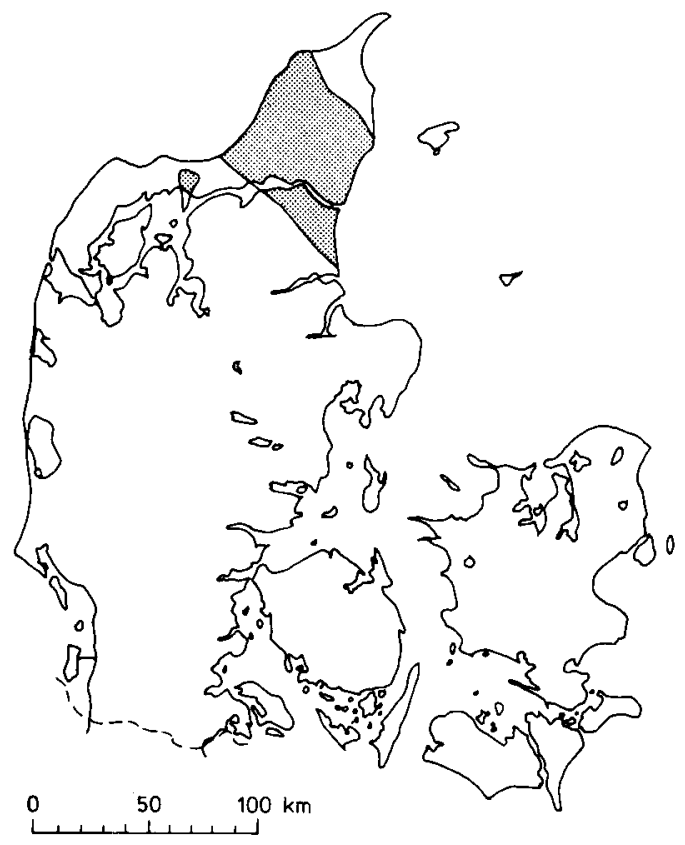

Område B

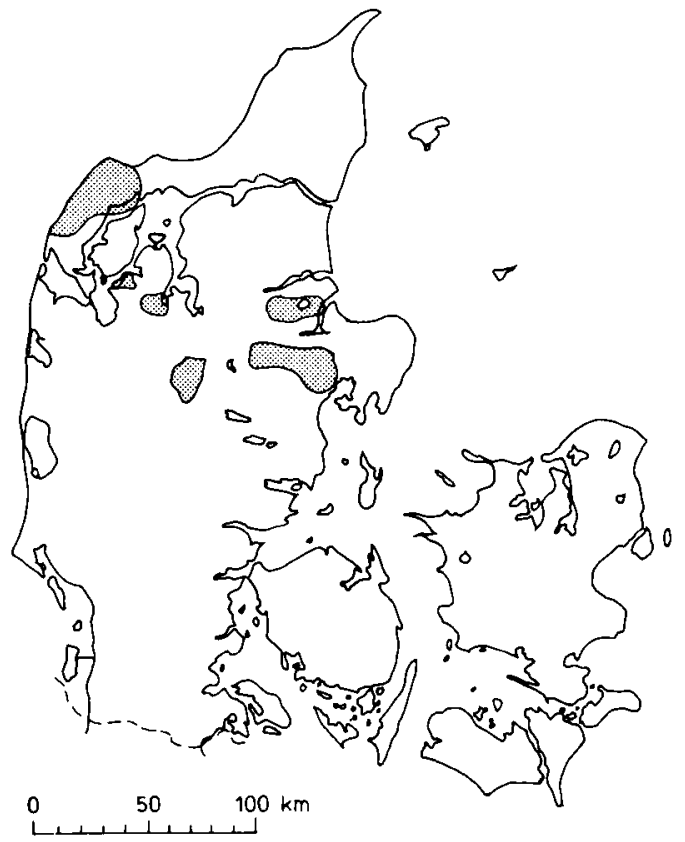

Område $\mathrm{Cl}$

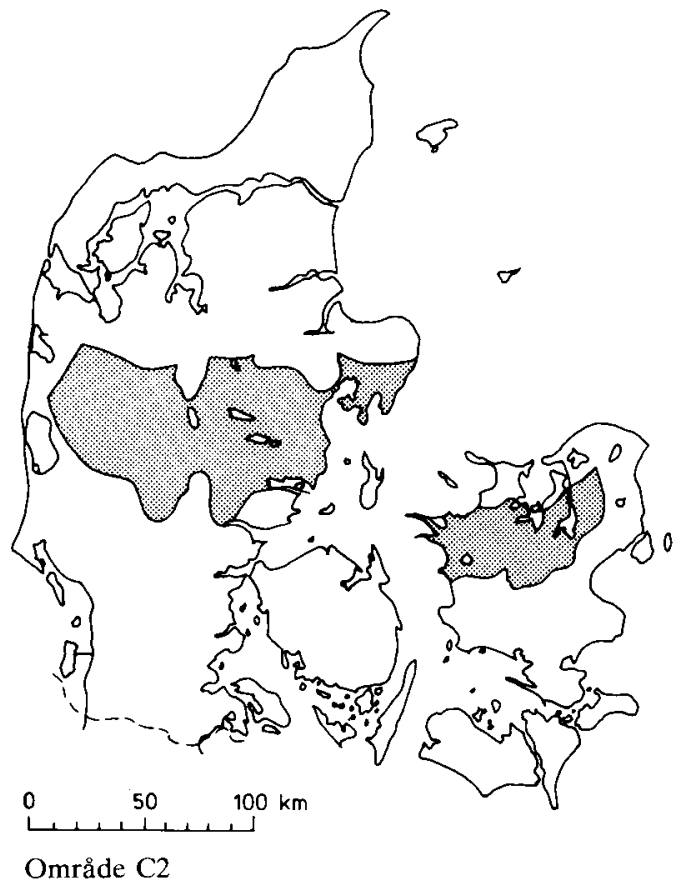

Fig. 45. Lokalitetskort for de fire områder hvori vurdering af reserverne er foretaget.

Fig. 45. Location maps of the four areas where the reserves have been evaluated. - The data are given in table 4 . 
Tabel 4 Datagrundlaget for vurderingen af reserverne

\begin{tabular}{|c|c|c|c|c|}
\hline Område & A & B & $\mathrm{Cl}$ & $\mathrm{C} 2$ \\
\hline Formation(er) & Gassum & Skagerrak & Tønder og Bunter & Bunter og Tønder \\
\hline Areal & $5200 \mathrm{~km}^{2}$ & $3100 \mathrm{~km}^{2}$ & $1700 \mathrm{~km}^{2}$ & $9000 \mathrm{~km}^{2}$ \\
\hline Dybde til reservoirmidte & $2500 \mathrm{~m}$ & $2500 \mathrm{~m}$ & $2500 \mathrm{~m}$ & $2500 \mathrm{~m}$ \\
\hline Temperatur & $85^{\circ} \mathrm{C}$ & $80^{\circ} \mathrm{C}$ & $80^{\circ} \mathrm{C}$ & $75^{\circ} \mathrm{C}$ \\
\hline Net sand tykkelse & $60 \mathrm{~m}$ & $250 \mathrm{~m}$ & $150 \mathrm{~m}$ & $80 \mathrm{~m}$ \\
\hline Brinepermeabilitet 1 & $100 \mathrm{mDarcy}$ & $50 \mathrm{mDarcy}$ & $50 \mathrm{mDarcy}$ & $40 \mathrm{mDarcy}$ \\
\hline 2 & $20 \mathrm{mDarcy}$ & $15 \mathrm{mDarcy}$ & 15 mDarcy & $15 \mathrm{mDarcy}$ \\
\hline Transmissivitet 1 & 6,0 Darcymeter & 12,5 Darcymeter & 7,5 Darcymeter & 3,2 Darcymeter \\
\hline 2 & 1,2 Darcymeter & 3,75 Darcymeter & 2,25 Darcymeter & 1,2 Darcymeter \\
\hline Porøsitet & $20 \%$ & $20 \%$ & $20 \%$ & $20 \%$ \\
\hline
\end{tabular}

det samlede energiindhold, der netto kan udnyttes, når der tages hensyn til, at der skal forbruges energi til pumpearbejde m.v. for at udvinde og anvende den geotermiske energi. Derimod fremgår det klart af undersøgelsen, at transmissiviteten har stor indflydelse på de økonomiske forhold. Endvidere viser det sig, at udnyttelsesgraden vokser med reservoirtemperaturen, hvorimod et højt fjernvarmetemperaturniveau har den modsatte virkning. Vurderingen resulterer i en værdi for udnyttelsesgraden på ca. $14 \%$.

De vigtigste beregningsresultater er sammenfattet $i$ appendix 3. Her er resultaterne for de 4 områder og for det samlede område tabelleret for to forskellige transmissivitets- og fjernvarmetemperaturniveauer.

Når resultaterne opsummeres giver vurderingen en total bruttoeffekt på ca. $150 \mathrm{GW}$ og en total nettoeffekt på ca. $60 \mathrm{GW}$. Det vil sige, at hvis de samlede undersøgte områder blev udnyttet, ville de i 25 år kunne levere en fjernvarmeeffekt på ca. $150 \mathrm{GW}$ ved hjælp af den geotermiske nettoeffekt på ca. $60 \mathrm{GW}$ og en brændselseffekt på ca. $90 \mathrm{GW}$.

Idet hele landets nuværende effektforbrug til rumopvarmning er ca. $10 \mathrm{GW}$, ses det, at der er tale om ganske betydelige reserver.

Effektfaktoren, der er forholdet mellem fjernvarmeeffekten og brændselseffekten, er fundet til ca. 1,7. Da effektfaktoren for et konventionelt fjernvarmeværk er ca. 0,85 , kan det konkluderes, at i de områder, hvor det er geologisk, teknisk og økonomisk muligt at anvende geotermisk energi i stedet for, kan ca. havldelen af brændselsforbruget spares.

$\mathrm{Da}$ det samlede undersøgte områdeareal er ca. $19000 \mathrm{~km}^{2}$, findes i middel en bruttoeffekttæthed på ca. $8 \mathrm{MW} / \mathrm{km}^{2}$ og en nettoeffekttæthed på ca. 3 $\mathrm{MW} / \mathrm{km}^{2}$.

Mens de fundne værdier for brutto- og nettoeffekttæthederne varierer med op til en faktor 3 fra tilfælde til tilfælde, er de beregnede værdier for effektfaktoren og udnyttelsesgraden næsten konstante.

Det fremgår af undersøgelsen, at det tilsyneladen- de gunstigste område, når markedsforholdene ikke tages i betragtning, er område B. Da det geologiske kendskab til dette område imidlertid er meget begrænset, skal nødvendigheden af yderligere geologiske undersøgelser i dette område påpeges.

Endelig skal det understreges, at den væsentligste årsag til, at kun en mindre del af landets energiforbrug til rumopvarmning vil kunne dækkes ved hjælp af geotermiske anlæg (såvel som ved hjælp af andre fjernvarmeanlæg) er de meget store omkostninger ved distributionen af fjernvarmevandet.

\section{Tak}

Dansk Olie \& Naturgas A/S takkes for at have taget initiativet til projektet og nedsat en arbejdsgruppe fra de tre nedennævnte institutioner. For frigivelse af borehulsdata fra Hyllebjerg 1, Skive 1, Kvols 1, Rødding 1 og Oddesund 1 takkes Dansk Boreselskab A/S. Borekerneanalyser, tegninger, fotografisk reproduktion, korrektion af den engelsksprogede tekst og renskrivning af manuskriptet er udført med omhyggelighed af personale ved Danmarks Geologiske Undersøgelse, Forsøgsanlæg Risø og Laboratoriet for Geofysik ved Aarhus Universitet. Alle de der på denne måde har bidraget til projektets gennemførelse eller har deltaget i den faglige diskussion bringes hermed vores bedste tak.

\section{Acknowledgements}

This project was initated by Dansk Olie \& Naturgas $\mathrm{A} / \mathrm{S}$ and carried out by a research team of the Geological Survey of Denmark, Risø National Laboratory, and Laboratory of Geophysics at Aarhus University. Dansk Boreselskab A/S has released well-data from 
the Hyllebjerg 1, Skive 1, Kvols 1, Rødding 1, and Oddesund 1 borings for this publication. The core analyses, drawings, photographic reproductions, and the manuscript have been carefully and responsibly prepared by the staffs of the Geological Survey of Denmark, Risø National Laboratory, and the Laboratory of Geophysics at Aarhus University. We have also benefitted from valuable discussions with the many individuals who have interested themselves in the project. - We wish to extend our sincere thanks to all who have contributed to its success.

\section{English Summary}

\section{Mapping of potential geothermal reservoirs in Denmark}

The present report is the result of a research program initiated in 1978, when the Danish exploration company Dansk Olie \& Naturgas A/S (D.O.N.G.) was allocated exclusive rights to explore for and to produce geothermal energy. The program was undertaken by the Geological Survey of Denmark (DGU), Risø National Laboratory, and Laboratory of Geophysics at Aarhus University, with the purpose to evaluate the feasibility of production of geothermal energy and of locating the most promissing areas. The program was to include analyses and evaluations of existing geological, geophysical, and geothermal data and acquisition of new data.

The first general chapter comprises a review of the geological, structural, and stratigraphical aspects as well as of the environments of deposition, from the relevant parts of the Danish subsurface sedimentary sequence. The main structural elements are shown in fig. 1, and the chronostratigraphical and lithostratigraphical subdivision of the sequence are illustrated in fig. 2. Further details may be found in the literature cited.

The criteria used to select the reservoir formations dealt with in the present report are described in the following chapter. In preparing the project, it was decided that all formations mentioned in former reports would be included in order to assure that all latent potentialities in these preliminary studies would be dealt with. The Palaeozoic formations included are known from few boreholes only, whereas the five Triassic and two Jurassic - Lower Cretaceous formations are rather well known.

\section{Evaluation of temperatures}

The reservoir temperature evaluations are based on the measured values (mostly BHT-values) and newly calculated model values. The isothermal maps presented in the present report are model maps constructed on the basis of $10^{\prime} \times 6^{\prime}$ or $5^{\prime} \times 3^{\prime}$ "grid" temperatures calculated as solutions (eq. (3), p. $x x$ ) to the one-dimensional heat equation (eq. (2), p. xx). From sea level to the basis of the Triassic, the thermal models used consist of 7 layers, each having a constant vertical thermal conductivity (tables 1 and 2, p. $\mathrm{xx})$. These conductivities are estimated from sample measurements (appendix 2 and fig. 3) and, indirectly, from heat flux and temperature gradient measurements or estimates in deep boreholes (fig. 6). Radioactive heat production is measured at low values (appendix 2 and fig. 4) with insignificant temperature influence at depths of main interest. A constant model value of $1.0 \mu \mathrm{W} \mathrm{m}^{-3}$ is used. Three temperature models (A, B, and C) are presented. The parameters preferred are used in model A; model B and C contain a combination of conductivity and heat flux which produces lower (B) and higher (C) temperatures. Information on the geothermal flux exists from only few localities (fig. 5). Based on those values and the observed variations in regions adjacent to Denmark, the constant values of 60,50 , and $80 \mathrm{~mW}^{-2}$ are chosen for models $\mathrm{A}, \mathrm{B}$, and $\mathrm{C}$, respectivily.

At the present stage of knowledge no lateral thermal conductivity and heat flux variations could be modelled. Most of the depth values at grid points are read from the generalized depth maps (figs. 14, 23, 30 and 37).

Models A, B, and C isothermal maps are presented for Near Top Triassic (figs. 24, 25, and 26), Base Haldager Sand (figs. 31, 32, and 33) and Base Upper Cretaceous limestone (figs. 38, 39, and 40). Model A isotherms are presented for the approximate base Triassic (fig. 15) and for the depths of 2000 and 3000 $m$ (figs. 42 and 44). The reservoir temperature evaluations are based mainly on model $A$ results. In areas without or with only poor information the temperature range given by models $\mathrm{B}$ and $\mathrm{C}$ is to be considered.

\section{Evaluation of porosity, permeability, and net sand thickness}

The evaluation is based on petrophysical logs and core analyses. The porosity values based on petrophysical logs are calculated from the following: 
Formation Density Log

Neutron Log, Compensated

FDC

$\mathrm{CNL}$

Sonic Log, Interval Transit Time

ITT

Spontaneous-Potential Log

Resistivity Log

The log quality from the Danish onshore borcholes varies greatly as they have been measured over nearly a 35 year period.

As far as possible each $\log$ has been evaluated, calibrated, and corrected for borehole diameter, drilling fluid, temperature, and lithology. For each borehole, the $\log$ has been used for identification of the reservoir beds which have been subdivided into a series of $0.5-5 \mathrm{~m}$ thick layers with homogeneous petrophysical characters. The porosity values tabulated are weighted average values for the individual beds; similary, the values for the reservoirs are weighted values based on the individual beds.

Plugs drilled from cores have been used for measuring porosity and air-permeability. Furthermore, parameters such as grain size, sorting, and degree of consolidation have been evaluated from microscopic studies of the plugs as well as of the drill cores.

Porosity has been measured on the plugs using the Boyle's Law method or by injection of mercury and measurements of the injected volume. (The latter has been used as a supplementary method).

Permeability has been measured as air-permeability: The relative pressure needed to force a given volume of nitrogen through the plug.

The accuracy for the porosity measurements is within $1 \%$; for permeability, within $10 \%$. The porosity, permeability, net sand thickness, and mid depth values are presented in the table, appendix 1 , in the figures $12,13,18,19,21,22,28,29,35$, and 36 , and in plates $1-8$.

\section{Depth mapping}

As a basis for evaluation of depth and extent of the reservoirs, reflection seismic data have been interpreted and isochrone maps for continuous reflectors have been drawn. Approximately 450 seismic lines with a total length of $9000 \mathrm{~km}$ have been interpreted, and well-velocity surveys from 22 boreholes in Jylland have been used for correlation between lithostratigraphic boundaries and seismic reflectors.

Two way time maps have been the basis for constructing the following generalized depth maps: Base Upper Cretaceous (fig. 37), Base Haldager Sand (fig. 30), Near Top Triassic (fig. 23), and Near Top Bunter
Sandstone Formation (fig. 14). Two way time maps for top Triassic are presented at plates 9-10.

Conversion of time maps to depth maps has been done by estimating regional velocity functions for each horizon from the two-way time values, and the depth figures from boreholes with well-velocity surveys. On Sjalland it has been necessary to use stacking velocities, as well control is missing. The estimated velocity functions may differ from the borehole data with values up to $250 \mathrm{~m}$, thus local corrections have been imperative. The time maps have not been migrated.

In regions without seismic data or where mapping has not been carried out, the depth contours have been constructed from borehole data and controlled by selected seismic lines.

\section{Description of the reservoir formations}

For each formation, the lithostratigraphy, geological age, lithology, geometry, depth, porosity, permeability, and temperature are described. Of all the formations formally established in the literature, only the Skagerrak Formation is not described individually below. It is a marginal deposit which is time equivalent with the most of the other Triassic formations (cf. Bertelsen 1980). Centrally in the Danish Subbasin, there is a more or less homogeneous transition zone between the Skagerrak Formation and the other Triassic formations - except for the Gassum Formation. Therefore the data for the Skagerrak Formation are included in the description of the relevant formations.

Presented with each formation description are maps showing thickness, mid depth, porosity, permeability, and temperature. The isopach curves are based mainly on figures read from the petrophysical logs; therefore the isopach curves show only the relative regional variation.

All depth figures are given in metres and refer to mean sea level (MSL).

\section{Palaeozoic}

Apart from formations referred to a specific part of the Palaeozoic, deposits of presumed Palaeozoic age are also included in the map fig. 9.

\section{Cambrian quartzitic sandstone}

Fig. 9, appendix 1.

Lithostratigraphic subdivision: Presumably equivalent with the Balka Quartzite (island of Bornholm).

Geological age: Lower Cambrian or Eocambrian. 
Lithology: Light grey quartzitic sandstone.

Extension, thichness, and depth: In the Slagelse 1 borehole a $6 \mathrm{~m}$ thick series is found, which is not penetrated. The formation is probably present in large areas in the easterly Danish region.

Depth to the top is $2928 \mathrm{~m}$.

Porosity and permeability: Porosity is $4 \%$ and permeability $3 \mathrm{mD}$.

Temperature: For the Slagelse 1 boring, the calculated values as well as the measured BHT indicate ca. $90^{\circ} \mathrm{C}$.

Final remarks: The formation is evaluated not to be a suitable geothermal reservoir.

\section{Carboniferous limestone}

Fig. 9, appendix 1.

\section{Lithostratigraphical subdivision: None.}

Geological age: Lower Carboniferous, Viséan.

Lithology: Limestone, marlstone, and claystone with subordinate silt/sand intercalations. Limestone dominates the uppermost $50 \mathrm{~m}$ as well as the lowermost $100 \mathrm{~m}$ of the penetrated series in the Ørslev 1 borehole. It is hard, very dense, reddish-grey to greyish-black with numerous fossil fragments. Carbonate grains make up approximately $30 \%$ of the rocks which further consists of fine grained or crystalline carbonate.

Extension, thickness, and depth: The Carboniferous limestone is only found in the Ørslev 1 boring, but is also expected to be present in the southern part of the Danish area. The drilled section is $525 \mathrm{~m}$ thick and the maximum thickness of the carbonates is $200 \mathrm{~m}$.

Top of the limestone is found at $2035 \mathrm{~m}$.

Porosity and permeability: The highest porosity found is $8 \%$.

Temperature: $60-70^{\circ} \mathrm{C}$ is normal for $2000 \mathrm{~m}$ depth in that region.

Final remarks: The limestone is dense and interbedded by claystone. It is estimated not to be a suitable geothermal reservoir.

\section{Rotliegendes sandstone}

Fig. 9. appendix 1.

\section{Lithostratigraphical subdivision: None.}

Geological age: Pre-Zechstein, Rotliegendes (infered).

Lithology: Sandstone and siltstone intercalated by clay. Reddish brown. Scattered limestone and anhydrite-concretions occur. Especially south of the Ringkøbing-Fyn High, the silty and sandy beds often have a fine grained matrix.
Extension, thickness, and depth: The sandstone formation is found predominantly south of the High, and only occasionally on the High and north of it. The maximum thickness registered south of the High is $225 \mathrm{~m}$, on the High $170 \mathrm{~m}$, and in the Danish Subbasin less than $100 \mathrm{~m}$. The top of the formation is found at $1800 \mathrm{~m}$ to $3100 \mathrm{~m}, 1200 \mathrm{~m}$, and $4800 \mathrm{~m}$ respectively.

Porosity and permeability: The porosity seems to reflect local variations of the lithology, rather than being depth related. $10 \%$ is the general figure, with a single deviation to ca. $20 \%$. Permeability - ca. $4 \mathrm{mD}$.

Temperature: For the depth interval 1800-3100 m, the temperature typically is between 60 and $80^{\circ} \mathrm{C}$, on the High $(1200 \mathrm{~m}) \mathrm{ca} .40^{\circ} \mathrm{C}$, and in the Subbasin $(4800 \mathrm{~m})$ approximately $140^{\circ} \mathrm{C}$.

Final remarks: The formation is assumed to have an inferior value as geothermal reservoir. However, the data density is small.

Zechstein carbonates south of the Ringkøbing-Fyn High

Fig. 10, appendix 1 .

Lithostratigraphical subdivision: Z-1, Z-2, and Z-3 Carbonate Formations, Middle Carbonate Member of the Anhydrite Formation (Clark \& Tallbacka, 1980).

Geological age: Upper Permian, Zechstein.

Lithology: Limestone, which is a subordinate part of a cyclic deposit of limestone, anhydrite, and halite.

Three types of limestones dominate: 1) very finegrained, 2) up to $50 \%$ carbonate grains in a fine grained matrix, and 3) algal boundstone (rarely bryozoan boundstone).

The most coarse-grained deposits are found in a region close to and parallel with the Ringkøbing-Fyn High, whereas the more fine-grained material is found further south in the Basin.

Extension, thickness, and depth: The maximum thickness (in total $125 \mathrm{~m}$ ) of the limestone series is found marginally, along the Ringkøbing-Fyn High. The depth varies from $2000 \mathrm{~m}$ to $3000 \mathrm{~m}$.

Porosity and permeability: The general porosity values are low, ca. 10\%, and the air-permeability, ca. $1 \mathrm{mD}$. Dissolution, fissures etc. have created a patchily distributed secondary porosity and permeability which have not been evaluated.

Temperature: In the above-mentioned depth interval the temperature will normally range between $60^{\circ} \mathrm{C}$ and $90^{\circ} \mathrm{C}$.

Final remarks: The stated reservoir characteristics disregard the secondary porosity and permeability 
which may turn it to a profitable geothermal reservoir.

\section{Triassic}

\section{Bunter Sandstone Formation}

Figs. 11-14, appendix 1.

Lithostratigraphical subdivision: Bacton Group, Bunter Sandstone Formation (Bertelsen 1980).

Geological age: Lower Triassic, Jakutian to Lower Olenikian.

Lithology: Red-brown and yellow-brown, finegrained sand-, silt-, and claystone, locally with a high content of carbonate, anhydrite and mica. Regional variation: 1) fine-grained sandstone and siltstone south of the Ringkøbing-Fyn High, 2) fine- to coarse-grained sandstone north of the High, and 3) further to the north in the Danish Subbasin, the coarsegrained sandstone of the Skagerrak Formation.

Extension, thickness, and depth: The formation covers the basins and, partly, the Ringkøbing-Fyn High.

Generally the thickness does not exceed $300 \mathrm{~m}$, however, centrally in the Danish Subbasin the Bunter Sandstone Formation/ Skagerrak Formation is estimated to be more than $900 \mathrm{~m}$ thick. On the High, the series is thin or locally missing.

Net sand thicknesses vary, probably locally.

The top of the formation is found at $1000-1500 \mathrm{~m}$ on the High, dipping to $2000 \mathrm{~m}$ in the North German Basin and $5000 \mathrm{~m}$ in the Danish Subbasin.

Porosity and permeability: Both of the parameters decrease with increasing depth. 20-30\% porosity is found at $1000-2000 \mathrm{~m}$ and less than $15 \%$ below $3000 \mathrm{~m}$. The highest air-permeability found is ca. $1000 \mathrm{mD}$.

The best properties are assumed to be found close to the flanks of the Ringkøbing-Fyn High because of the suitable depth of the formation. Northernmost in the Danish Subbasin, the Skagerrak Formation may locally have good reservoir characteristics.

Temperature: On the High the temperature is estimated to be $30-50^{\circ} \mathrm{C}$ and in South Jylland, $60-80^{\circ} \mathrm{C}$. In the Mors 1 boring corrected BHT-values indicate temperatures between $110^{\circ} \mathrm{C}$ and $140^{\circ} \mathrm{C}$. Centrally in the Subbasin, the temperature exceeds $140^{\circ} \mathrm{C}$. Model A isoterms shown in fig. 15 refer to the approximate base Triassic horizon.

Final remarks. The value of the depth map, fig. 14, is impaired by essential uncertainties, as the relevant velocity functions, necessary for depth conversion of the two-way time map to depth map, are missing.
The reservoir properties have been evaluated on very few core analyses and SP-resistivity measurements. However, on the basis of this material the formation is supposed to have geothermal reservoir characteristics.

\section{$\emptyset$ rslev Formation}

Fig. 16.

Lithostratigraphical subdivision: Lolland Group, Ørslev Formation (Bertelsen 1980).

Geological age: Lower to Middle Triassic, Upper Olenikian to Lower Anisian.

Lithology: The formation can be subdivided into a lower and an upper part. The lower part is dominated by halite and anhydrite interbedded by claystone in the southern region, and by dolomitic limestone, claystone, and marlstone in the northern region. The upper part of the formation consists of silty, reddishbrown claystone. Anhydrite occurs sporadically throughout the entire formation. In the regional transition zone to the Skagerrak Formation, siltstone may dominate the formational sequence.

Extension, thickness, and depth: The formation covers nearly the whole study area.

The general thickness found is $100-300 \mathrm{~m}$, thinning on the Ringkøbing-Fyn High, and exceeding $400 \mathrm{~m}$ centrally in the Danish Subbasin.

In the table (appendix 1) and on the maps, the net sand thickness is calculated together with the figures from the Bunter Sandstone Formation. Within the above-mentioned transition zone to the Skagerrak Formation, the total thickness of the sand-siltstone beds is $50-150 \mathrm{~m}$.

Top of the formation is found at $800-1500 \mathrm{~m}$ on the High, dipping to $1800-2000 \mathrm{~m}$ to the south, and to more than $4000 \mathrm{~m}$ centrally in the Danish Subba$\sin$.

Porosity and permeability: $3-5 \%$ porostity. Permeability is supposed to be inconsiderable as the sediments are very fine-grained.

Temperature: Centrally in the Subbasin the temperature is estimated to exceed $120^{\circ} \mathrm{C} .35-50^{\circ} \mathrm{C}$ on the High and $60-70^{\circ} \mathrm{C}$ south of the High are estimated as typical temperatures.

Final remarks: Though the formation is poorly known, it is evaluated to have inferior geothermal reservoir characteristics. In the transition zone to the Skagerrak Formation, it may be evaluated together with other Triassic formations.

\section{Falster Formation}

Fig. 17. 
Lithostratigraphical subdivision: Lolland Group, Falster Formation (Bertelsen 1980).

Geological age: Middel Triassic, Anisian to Lower Ladinian.

Lithology: Grey and greyish-green, rarely brown claystone, marlstone, and limestone, with scattered occurrences of anhydrite. Generally limestone is common in the lower part of the formation, and claystone in the upper part. Intercalations of sand occur in the transitional zone to the Skagerrak Formation in the Danish Subbasin.

Extension, thickness, and depth: The formation covers nearly the whole study area (cf. fig. 17).

The thickness is generally between 100 to $200 \mathrm{~m}$, but the net sand thickness is inferior. A few $5 \mathrm{~m}$ thick sand-siltstone beds are found in the above-mentioned transitional zone.

On the Ringkøbing-Fyn High, the depth ranges from $800 \mathrm{~m}$ to $1200 \mathrm{~m}$, south of the High to $1500 \mathrm{~m}$, and centrally in the Subbasin to below $3700 \mathrm{~m}$.

Porosity and permeability: $10 \%$ porosity. Based on the mixed lithology and on the cemented sandstone, the permeability is also concluded to be low.

Temperature: South of the Ringkøbing-Fyn High the temperature is evaluated to be approximately $50^{\circ} \mathrm{C}$, on the High $30-40^{\circ} \mathrm{C}$, and more than $100^{\circ} \mathrm{C}$ centrally in the Subbasin.

Final remarks: The formation is poorly known, but is assumed not to have a suitable geothermal potential.

\section{Tønder Formation}

Figs. 11, 18-19, appendix 1.

Lithostratigraphical subdivision: Jylland Group, Tønder Formation (Bertelsen 1980).

Geological age: Middle Triassic, Upper Ladinian.

Lithology: Reddish brown to greenish, silty claystone with scattered occurrence of anhydrite. A few well-defined beds of greyish-green and reddishbrown, silty, fine-grained sandstone are found uppermost in the formation.

To the north in the Danish Subbasin, the sand content and the number of sand beds increase, but the beds are thinner and the sorting grad lower.

Extention, thickness, and depth: The formation is found all over the study area, but may be absent on the Ringkøbing-Fyn High. To the north a regional transition zone to the Skagerrak Formation is found. In the southeastern part of the Danish Subbasin, the lithological characteristics change and the series is referred to the Ringe Beds (cf. Bertelsen 1980). Reservoir properties of the Ringe Beds are calculated here together with those of the Tønder Formation.
Average thickness is between 100 and $300 \mathrm{~m}$. Net sand thickness is only $20-40 \mathrm{~m}$, but up to $100 \mathrm{~m}$ in the Danish Subbasin.

Depth to top of the Formation is $800-1000 \mathrm{~m}$ on the High, 1000-1500 $\mathrm{m}$ in South Jylland, and more than $3500 \mathrm{~m}$ in parts of the Subbasin.

Porosity and permeability: The porosity values vary very greatly. In well-defined sand beds in South Jylland, the porosity is $20-30 \%$ or more. The porosity values are smaller in the Subbasin, probably due to clay content and cementing.

The porosity decreases with depth, from $30-40 \%$ at $1000 \mathrm{~m}$ to $10 \%$ at $3500 \mathrm{~m}$ (fig. 11). In series with good reservoir properties, the air-permeability is $1000 \mathrm{mD}$ but, in beds with low porosity values, the permeability values are significant smaller.

Varying sedimentary facies and cementing may be the reason for changing values of porosity and permeability within short distances.

Temperature: More than $100^{\circ} \mathrm{C}$ is expected centrally in the Danish Subbasin. On the northern flank of the Ringkøbing-Fyn High $75^{\circ} \mathrm{C}$ seems typical, 30$40^{\circ} \mathrm{C}$ on the High, and $60^{\circ} \mathrm{C}$ south of the High.

Final remarks: Well data on the Tønder Formation are scarce, but based on available data the Formation is interpreted to have geothermal reservoir characteristics.

\section{Gassum Formation}

Figs. 20-26, appendix 1.

Lithostratigraphical subdivision: Mors Group, Gassum Formation (Bertelsen 1978 and 1980).

Geological age: The formation is diacron. Centrally in the Danish Subbasin it is of Upper Traissic age (Rhaetian), but marginally (to the north) it is mainly of Lower Jurassic age (Hettangian to Sinemurian).

Lithology: Fine to medium-grained, light grey sandstone, interbedded by claystone and siltstone. Scattered coal beds occur. Generally the Formation is subdivided into three members, a lower and an upper dominated by sandstone, and a middle member with claystone and siltstone. Locally additional members may occur uppermost and lowermost. As a regional trend, the Formation is characterized by being more fine-grained to the south.

Extension, thickness, and depth: The main extension is found in the Danish Subbasin (see fig. 21). The general thickness here is $100-200 \mathrm{~m}$, but exceeding $200 \mathrm{~m}$ in North Sjælland and northern Jylland.

The net sand thickness varies locally, but generally exceeds $50 \mathrm{~m}$ in the central parts of the Danish Subbasin (northern Jylland and North Sjælland). South of 
the Ringkøbing-Fyn High, on the islands of Lolland and Falster, it exceeds $50 \mathrm{~m}$ locally.

The Formation is deepest in the central part of the Subbasin, south of the Limfjord. The depth varies from $2400 \mathrm{~m}$ to approximately $4000 \mathrm{~m}$, varying greatly within short distances because of the strong influence of halokinesis in this region. In a regional zone from Djursland to North Sjælland, the depth is more than $2500 \mathrm{~m}$, but in the marginal zones to the south and the northeast, it decreases to $500-1000 \mathrm{~m}$.

Porosity and permeability: The porosity decreases with the depth; down to $1500 \mathrm{~m}$ it is $30-40 \%$, at $2000 \mathrm{~m}$ approximately $25 \%$, and at $3000 \mathrm{~m} 12 \%$. Generally the brine-permeability varies from $8 \mathrm{mD}$ at $3200 \mathrm{~m}$ to $300 \mathrm{mD}$ at $1500 \mathrm{~m}$ depth. However, such parameters as the grain size and the clay content influence the permeability, so a general correlation to porosity and depth cannot always be established. An example is found in the very low permeabilities measured in the Frederikshavn 2 and Skagen 2 borings (cf. fig. 22).

Temperature: The formation temperatures at 1000 , 2000 , and $3000 \mathrm{~m}$ depth are estimated to be $35-45^{\circ} \mathrm{C}, 60-75^{\circ} \mathrm{C}$, and $80-110^{\circ} \mathrm{C}$ respectively. The highest temperatures, $100-120^{\circ} \mathrm{C}$, are expected centrally in the Danish Subbasin. Model A isoterms for "Near Top Triassic" (fig. 24) are regarded as the best basis for a regional evaluation. Grood accordance between those model values and the measured values is found for the central part of the Subbasin. Outside this area the models $B$ and $C$ isoterms must be included in the evaluation of the temperature, due to missing control points. Anomalous high temperatures may be found in areas with a great thickness of the overlying Fjerritslev Formation and a thin Upper Cretaceous limestone series.

Final remarks: Due to missing seismic data and/or velocity analyses, the depth mapping of Top Triassic (partly top Gassum Formation) is rather uncertain in the margin of, and outside, the Danish Subbasin.

For evaluation of the reservoir parameters the well data density is sufficient in northern Jylland only.

Based on the present data, the Formation is estimated to have good geothermal reservoir properties in northern Jylland. In North Sjælland it may be a potential reservoir.

\section{Jurassic - Lower Cretaceous}

\section{Haldager Sand}

Figs. 27-33, appendix 1.

Lithostratigraphical subdivision: Haldager Formation, Haldager Sand (Michelsen 1978).
Geological age: Middle Jurassic.

Lithology: Light olive grey, fine to medium-grained sandstone and siltstone, which may contain mica, plant remains, and coal. The sandstone beds are interbedded by thin claystone layers. In the southwestern part of the deposition area, the sequence is thin with varying lithology, including badly sorted sandstone and clayey and sandy siltstone.

Extension, thickness, and depth: The Haldager Sand is found in the main part of the Danish Subbasin. The maximum thickness, ca. $150 \mathrm{~m}$, is in southeastern Vendsyssel. $25-30 \mathrm{~m}$ is the general thickness in the central and northeastern parts of the Subbasin. Locally great thicknesses are found in the rim synclines; e.g. south of Linde-Vejrum and at Tostrup saltstructures.

Depth to top of the Haldager Sand varies from $1000-2000 \mathrm{~m}$ to more than $3000 \mathrm{~m}$ centrally in the Subbasin. In the rim synclines the depth may be more than $2500 \mathrm{~m}$.

Porosity and permeability: Generally the porosity decreases with the depth; e.g. from $30 \%$ at $1500 \mathrm{~m}$ to $20 \%$ at $2500 \mathrm{~m}$.

Air-permeability has been measured from only 3 boreholes. It varies from $2000 \mathrm{mD}$ at $33 \%$ porosity to $500 \mathrm{mD}$ at $21 \%$.

Temperature: The model $\mathrm{A}$ isoterms (cf. fig. 31) are regarded as a reliable basis for the regional evaluation. However, in the northernmost Jylland the model B and/or C may be used. Typically the temperature is found to be between 60 and $80^{\circ} \mathrm{C}$, and with a maximum of $80-100^{\circ} \mathrm{C}$ centrally in the Subbasin.

Final remarks: The Haldager Sand is evaluated to have reasonable good reservoir characteristics (incl. depth) in Himmerland and on the island of Mors. However, the net sand thickness cannot be determined due to missing well data in these regions. Seismic data indicate considerable sand-bed thicknesses in the rim synclines associated with certain salt structures.

\section{Frederikshavn Member}

Figs. 34-36, appendix 1.

Lithostratigraphical subdivision: Bream Formation, Frederikshavn Member (Michelsen 1978).

Geological age: Upper Jurassic to Lower Cretaceous, Kimmeridgian to Valangian.

Lithology: Siltstone and fine-grained sandstone interbedded by silty claystone. The sandstone may be clayey and mica, pyrite, microlignite, and glauconite may occur.

The general grain size, thickness, and number of sandstone beds increase to the northeast. 
Extension, thickness, and depth: The Member is found only in Jylland north of the Ringkøbing-Fyn High.

The thickness of the Member varies from 50-250 $\mathrm{m}$, and the net sand thickness, from 5-35 $\mathrm{m}$ in Himmerland to $70 \mathrm{~m}$ in Vendsyssel. The depth to the top of the Member is approximately $1000 \mathrm{~m}$, but more than $2000 \mathrm{~m}$ centrally in the Subbasin and $200 \mathrm{~m}$ northernmost in Jylland.

Porosity and permeability: The porosity is relatively high, $25-35 \%$ at $1000 \mathrm{~m}$ depth to $15-20 \%$ at $2000 \mathrm{~m}$. The varying content of glauconite, mica and clay has a negative influence.

At $25-35 \%$ porosity the permeability is assumed to be $500-1000 \mathrm{mD}$.

Temperature: Model A isoterms give a reliable figure for the basis of Upper Cretaceous limestone (fig. 38), but for northernmost Jylland, model B and C may be used. In the deepest part of the Subbasin, the general temperature level will be $50-60^{\circ} \mathrm{C}$ and locally $70^{\circ} \mathrm{C}$.

Final remarks: In the deeper parts of the Subbasin, porosity and permeability values are low and the sequence is characterized by the scattered occurrence of thin sandstone beds of restricted extension. The Frederikshavn Member is evaluated to be of inferior value as a geothermal reservoir.

\section{Hydrochemistry}

Nearly all onshore boreholes in Denmark have been drilled for oil and gas exploration but, since there has been no success, only very few drill-stem tests have been carried out. Therefore, only the general trend of the chemical composition of the geothermal water can be given at present. As a rule the salinity of the water increases with the depth as follows: $10 \%$ at $1000 \mathrm{~m}, 20 \%$ at $2000 \mathrm{~m}$, and $30 \%$ at $3000 \mathrm{~m}$ (valid only for the sandstone formations).

\section{Regional reservoir evaluations}

Based on analyses and descriptions of the reservoirs and the seismic mapping of the relevant horizons the study area can be subdivided into 6 regions with differing geothermal reservoir characteristics. Only sequences within the depth interval 2000-3000 $\mathrm{m}$ have been included in the evaluation, as the temperature may be too low above $2000 \mathrm{~m}$ and the permeability too low below $3000 \mathrm{~m}$ due to diagenesis etc. These criteria are used here as a general basis, since no technical and economical factors have been studied in detail.

For the conclusions below, the depth maps have been used to select formations occurring in the mentioned depth interval and to present them in fig. 41 . On the basis of this map and on the studies of the reservoir rocks, the study area has been subdivided and classified into 6 regions as presented in fig. 43 . This classification gives a generalized picture of formations which may contain potential reservoirs in the different parts of the country.

As a general trend for the temperature interval in the sequence in question, Model $\mathrm{A}$ isotherms for 2000 and $3000 \mathrm{~m}$ are presented in figs. 42 and 44 respectively.

Area $A$ comprises the region with the Gassum Formation as the principal reservoir. The Haldager Sand is found in restricted areas within the depth interval.

In Jylland, the Gassum Formation is evaluated as having good reservoir characteristics, but of varying values. To the northeast the most positive characters are expected, and in parts of this area the Haldager Sand may be an alternative or supplementary reservoir.

In North Sjælland, the Gassum Formation is known only from the Lavø 1 boring, but based on known regional conditions good reservoir characteristics may be expected.

Area $B$ comprises the region where the Skagerrak Formation is the main target. In the sourthernmost part, the Gassum Formation is found below $2000 \mathrm{~m}$ depth and is expected to overlay the Skagerrak Formation directly. The reservoir characteristics are known only from two boreholes, and here only from the uppermost part of the Skagerrak Formation. The coverage and quality of the seismic data are poor and a reliable seismic mapping cannot be based on these data.

Thick sandstone beds and series are expected, but due to changes in the local sedimentary environmental conditions, the reservoir characteristics may vary both horizontally and vertically.

The northern boundary is drawn from poor seismic indications of the $2000 \mathrm{~m}$ depth conture for top preUpper Permian.

Area $C$ comprises the regions where the Bunter Sandstone and Tønder Formations may be the main target. Area $\mathrm{C}$ is subdivided into two regions marked "B" and "?T" on the map, fig. 43. The Gassum For- 
mation is either not situated deeply enough or has inadequate reservoir characteristics.

On Sjælland the deposits are known only from the seismic data, but due to the small distance to the Fennoscandian Border Zone, where corresponding deposits are known, it is reasonable to expect relatively good reservoir characteristics.

In Jylland, south of area A, these older Triassic formations are known only from two boreholes, and the coverage of seismic data is poor. The beds dip toward the north, so in the southern part, sub-area "B", the Bunter Sandstone Formation is found within the depth interval, and in the northern part, subarea "?T", the Tønder Formation is found. Sand content and grain size is supposed to increase toward the north.

Area $D$ comprises the region in South Jylland with Zechstein carbonates and, in the southwesternmost part of the region, the Bunter Sandstone Formation is an alternative reservoir.

The formations are known only partly, but further exploration and research of the reservoir parameters are reasonable.

Area $E$ is the region characterized by complicated structural features due to halokinesis, and by the occurrence of the Gassum Formation at depths of more than $3000 \mathrm{~m}$. The Haldager Sand and the Frederikshavn Member are found within the depth interval in question. Both members are evaluated to be of moderate value for geothermal exploration, as the Haldager Sand is thin and the Frederikshavn Member has a high clay content. Regarding reservoir properties the region is not homogeneous, but must be described in three sub-regions.

In the northeastern part, both members may have good reservoir characteristics. Centrally in this subregion, the Haldager Sand is situated below $3000 \mathrm{~m}$, and the net sand thickness of the Frederikshavn Member is unknown but probably small.

In the northwestern part, the Frederikshavn Member may be dominated by clay, whereas the Haldager Sand can be of extraordinary thickness in the rim synclines of the salt structures.

In the southwestern part, the Haldager Sand is indicated to have good reservoir properties, but is generally thin. Seismic data show considerable thickening of the sequence in some rim synclines.

Area $F$ comprises regions with basement at shallow depths - the Ringkøbing-Fyn High and the Fennoscandian Border Zone.

However, along the flanks of the High, Palaeozoic series with poor geothermal reservoir properties are present.

The above described subdivision of the Danish onshore region is a generalized review based on the distribution of known geothermal reservoir parameters. It is carried out to give a picture of the potential geothermal reservoirs as these can be evaluated on the basis of the present well data and seismic data.

Area $A$ is the most well known and is regarded as a positive region for geothermal exploration. Areas B and $C$ may turn out to be positive in the same sense, but supplementary well data and seismic data are necessary for reliable evaluation.

\section{Evaluation of the reserves}

On the basis of the geological and geophysical studies, an evaluation of the geothermal reserves in Denmark was carried out. The purpose of the appraisal is to determine how large a portion of the estimated resources can be utilized from an energy standpoint. No comprehensive consideration was given to economic and marketing aspects in this study; however, it was unavoidable that a simple economic analysis be brought into the assessment.

In the evaluation, areas $\mathrm{A}, \mathrm{B}$, and $\mathrm{C}$ are judged to be geothermically the most positive regions. Even though areas $\mathrm{B}$ and $\mathrm{C}$ are expected to have positive reservoir characteristics in only limited areas, in the appraisal they are taken in their full extension. On the other hand, areas D, E, and F are mainly not included, even though there can be good reservoir characteristics locally. Area $\mathrm{C}$ is divided into two sub-regions here, $\mathrm{C} 1$ and $\mathrm{C} 2$. In the assessment, the region is thus divided into four parts: $\mathrm{A}, \mathrm{B}, \mathrm{C} 1$, and $\mathrm{C} 2$, as is shown in fig. 45 .

The reservoir characteristics are assumed to be constant within each of the regions. The applied values are tabulated in table 4 . Because of the great uncertainty about transmissivity, two (equally probable) values for brine-permeability are given.

The assessment is undertaken partly to determine the total energy content of the reservoirs, and partly to calculate the extent to which the available energy can be utilized, assuming that extraction takes place with the aid of single plants with one production and one injection well. It is furthermore presumed that the energy is applied to district heating, where the temperature conversion between the geothermal and district heating cycle takes place by means of heat pumps.

The plant-lifetime is set at 25 years, and the 
district heating power for a single plant is determined as the economically optimized value worked out from a simple economic analysis.

In order to investigate the influence of the magnitudes of the input parameters in the calculations, a sensitivity analysis is taken for a single case. From this it is found that the magnitude of the reservoir transmissivity and of the economic data have practically no influence on the size of the net recovery factor; i.e., the net amount of the total energy content that can be utilized, when consideration is given to the energy consumed in the pump apparatus, etc., in order to extract and apply the geothermal energy. On the other hand, the study makes it clear that transmissivity greatly influences the economic relationships. Furthermore, the study shows that the recovery factor increases with the temperature of the reservoir, whereas a high district-heat temperature level has the opposite effect. The assessment results in a net recovery factor of approximately $14 \%$.

The most important of the computed results are summarized in appendix 3 . The results for the four areas, and the total region, are tabulated here for two different transmissivity and district heating temperature levels.

When the results are summed up, the appraisal gives total gross and net power values of approximately 150 and $60 \mathrm{GW}$, respectively. In other words, if the total investigated regions are utilized, they will be able to deliver a district heating power of $150 \mathrm{GW}$ for a 25-years period by means of the geothermal net power of approximately $60 \mathrm{GW}$, and fossil fuel power of approximately $90 \mathrm{GW}$.

As current power consumption for space heating for the entire country is approximately $10 \mathrm{GW}$, it is clear that we are speaking here of quite significant reserves.

The power factor - that is, the ratio between district heating- and fossil fuel power - is found to be 1.7. As the power factor for a conventional district heating plant is approximately 0.85 , it can be concluded that in the regions where it is geologically, technically, and economically possible to apply geothermal energy instead, fuel consumption can be reduced by approximately half.

As the collectively investigated regional area is approximately $19,000 \mathrm{~km}^{2}$, an average gross power density of approximately $8 \mathrm{MW} / \mathrm{km}^{2}$ is found, together with a net power density of approximately 3 $\mathrm{MW} / \mathrm{km}^{2}$.

While the values for the gross and net power densities found in the study vary by up to a factor of three, the calculated values for the power factor and net recovery factor remain essentially constant.
It is apparent from the study that the most favourable region is area $\mathrm{B}$, when market conditions are not taken into consideration. As geological knowledge of this region is presently very limited, it is necessary with further geological investigations to be conducted in this region.

\section{Litteratur}

Baartman, J. C. 1976: Structural outline of Denmark (Pre Permian). - In: Rasmussen, L. B. 1978: Geological aspects of the Danish North Sea Sector. - Danm. geol. Unders., III række, 44 $85 \mathrm{p}$.

Baartman, J. C. \& Christensen, O. B. 1975: Contributions to the interpretation of the Fennoscandian Border Zone. - Danm. geol. Unders., II række, 102, $47 \mathrm{p}$

Balling, N. 1976: Geothermal models of the Crust and Uppermost Mantle of the Fennoscandian Shield in South Norway and the Danish Embayment. - J. Geophys., 42, pp. 237-256.

Balling, N. 1976: Rapport over geotermiske energiundersøgelser i dybdeboringen Oddesund 1. - Laboratoriet for Geofysik, Aarhus Universitet, okt. 1976. (Optaget som Bilag 3.1 i Handelsministeriet 1977).

Balling, N. 1978: Geofysiske metoder til lokalisering af geotermiske energiressourcer. - Dansk geol. Foren. Årsskrift 1977, pp. 13-27.

Balling, N. 1979: Subsurface temperatures and heat flow estimates in Denmark. - In: Cermák \& Rybach (eds.), Terrestial heat flow in Europe, Springer Verlag, Berlin, pp. 161-171.

Balling, N. \& Madsen, L. 1978: Temperature Data and Isothermal Maps of Denmark. - EC Geothermal Report.

Balling, N. \& Saxov, S. 1978: Low enthalpy geothermal energy resources in Denmark. - Pageoph 117, pp. 205-212.

Balling, N. \& Saxov, S. 1979: Determination of Heat Flow, Temperature Distribution, Heat Productivity and Heat Production in Denmark. - EC second meeting on Heat Flow and Temperature Determinations, Brussels.

Balling, N., Kristiansen, J. I., Poulsen, K. D. \& Saxov, S. 1980: Geothermal trends of Denmark. - EC second International Seminar, Strasbourg.

Bertelsen, F. 1977: Trias lagserien i Det dansk-norske Bassin. Stratigrafisk inddeling og beskrivelse af Hyllebjerg, Kvols, Skive, Rødding, Oddesund - Danm. geol. Unders., Nord-Projekt, Rapport 4, 18 p.

Bertelsen, F. 1977: Trias lagserien i Det dansk-norske Bassin Lithologisk beskrivelse og lithostratigrafisk inddeling af trias $i$ Mors, samt korrelation mellem Mors-1, Gassum-1, Rønde-1. Danm. geol. Unders., Nord-Projekt, Rapport 6, 9 p.

Bertelsen, F. 1978: The Upper Triassic-Lower Jurassic Vinding and Gassum Formations of the Norwegian-Danish Basin. Danm. geol. Unders., Ser. B, 3, 32 p

Bertelsen, F. 1978: Triassic Well Data Sheets (reviderede lithostratigrafiske inddelinger). - Danm. geol. Unders., upubl. rapport, $17 \mathrm{p}$.

Bertelsen, F. 1980: Lithostratigraphy and depositional history of the Danish Triassic. - Danm. geol. Unders., Ser. B, 4, 59 p.

Bertelsen, F., Just, N., Michelsen, O., Jacobsen, J., Laier, T. \& Gosk, E. 1978: Mapping of Danish permeable and impermeable formations. - Geologisk - Geokemisk - Hydrologisk. - Upubl. EF-rapport. Danm. geol. Unders., 13 p. 
Bertelsen, F. \& Priisholm, S. 1978: Memorandum on the Triassic Series of the Central Part of the Danish Subbasin. - Danm. geol. Unders., confidential report, $7 \mathrm{p}$.

Christensen, O. B. 1971: Upper Silurian of the boring Nøvling No. 1 in Central Jylland. - Danm. geol. Unders., Rapp. 7, 24 p.

Clark, C. N. \& Tallbacka, L. (1980): The Zechstein deposits of southern Denmark. - Contr. Sedimentology, 9, pp. 205-231.

Danm. geol. Unders. 1977: Temperature measurements in exploration wells. - Danm. geol. Unders., upubl. rapport, $54 \mathrm{p}$

Danm. geol. Unders., Prækvartærafdelingen 1976: Geologisk vurdering af geotermisk energi i Danmark. - Danm. geol. Unders., upubl. rapport til Handelsministeriet, $73 \mathrm{p}$.

Gosk, E., Holm, L. \& Priisholm, S. 1979: Varmt porevand. - Varv 1979, 3, pp. 74-80.

Gosk, E. \& Jensen, P. K. 1980: "Hot dry rock" - en potentiel energikilde? - Dansk geol. Foren. Årsskrift 1979, pp. 99-103.

Haenel, R. (chief editor) 1980: Atlas of Subsurface Temperatures in the European Community. - Luxembourg.

Handelsministeriet 1977: Udnyttelse af geotermisk energi i Danmark. - Rapport fra Handelsministeriets arbejdsgruppe vedr. geotermisk energi, $72 \mathrm{p}$.

Hansen, J. M. \& Håkansson, E. 1980: Thistedstrukturens geologi et "Neotektonisk" skoleeksempel. - Dansk geol. Foren. Årsskrift 1979 , pp. 1-9.

Holm, L. 1978: Supplerende lithologisk beskrivelse af sandstenskerner. - Danm. geol. Unders., Upubl. rapport.

Holm, L. 1978: The grain size distribution in the sandstone. Cores from the Gassum Formation, Gassum No. 1. - Danm. geol. Unders., Upubl. rapport.

Holm, L. \& Priisholm, S. 1978: Porosity and permeability analysis of sandstone cores from the Gassum Formation, Upper Triassic, in the Gassum 1 well. - Danm. geol. Unders., Upubl. rapport, $16 \mathrm{p}$.

Jacobsen, J. \& Laier, T. 1978: Chemical analysis of brines from Danish boreholes. - Danm. geol. Unders., Upubl. rapport, 3 p.

Kristiansen, J. I. 1978: Teoretisk analyse af metoder til bestemmelse af varmeledningsevne for geologiske materialer og eksempler på anvendelse. - Upubl. specialeopgave, Lab. for Geofysik, Aarhus Universitet, $129 \mathrm{p}$.

Larsen, G. 1966: Rhaetic-Jurassic-Lower Cretaceous sediments in the Danish Embayment. - Danm. geol. Unders., II rakke, 91, $127 \mathrm{p}$.

Larsen, G. \& Friis, H. 1975 Triassic heavy-mineral associations in Denmark. - Danm. geol. Unders., Årbog 1974, pp. 33-47.

Larsen, O. 1971: K/Ar age determinations from the Precambrian of Denmark. - Danm. geol. Unders., II række, 97, 37 p.

Madirazza, I. 1977: Zechstein Bassinet og saltstrukturer i Nordjylland. - Dansk geol. Foren. Årsskrift 1976, pp. 57-68.

Madsen, L. 1975: Approximate geothermal gradients in Denmark and the Danish North Sea Sector. - Danm. geol. Unders., Årbog 1974, pp. 5-16.

Madsen, L. 1978: Geotermisk energi i Danmark - en geologisk vurdering. - Dansk geol. Foren. Årsskrift 1977, pp. 29-40.

Madsen, L. 1978: Notat vedr. seismiske forundersøgelser i forbindelse med forsøgsindvinding af geotermal vand. - Danm. geol. Unders., Upubl. rapport, 7 p.

Michelsen, O. 1971: Lower Carboniferous foraminiferal faunas of the boring Ørslev No. 1. - Danm. geol. Unders., II række, 98, $86 \mathrm{p}$.

Michelsen, O. 1976: Jura lagserien i Det dansk-norske Bassin. Revideret lithostratigrafi. Bassinudvikling. Stratigrafisk inddeling af Hyllebjerg, Kvols, Skive, Rødding, Oddesund. - Danm. geol. Unders., Nord-projekt, upubl. rapport 1, 43 p.

Michelsen, O. 1976: Kortfattet oversigt over de geologiske forhold i den danske del af Nordsøen. - Danm. geol. Unders., Årbog 1975, pp. 117-132.

Michelsen, O. 1976: Preliminary report on the Jurassic lithostratigraphic nomenclature in the Danish North Sea Area. Danm. geol. Unders., Årbog 1975, pp. 105-116.

Michelsen, O. 1978: Stratigraphy and distribution of Jurassic deposits of the Norwegian Danish Basin. - Danm. geol. Unders. Ser. B, $2,28 \mathrm{p}$.

Michelsen, O. 1979: Report on the Jurassic of the Hobro No. 1 and Voldum No. 1 borings, Denmark. - Danm. geol. Unders. Årbog 1978, pp. 141-150.

Michelsen, O. \& Andersen, C. (1980): Review of Danish regional geology and tectonics. - Zeitschrift für angewandte Geologie. In press.

Michelsen, O. \& Bertelsen, F. 1979: Den varme undergrund. Geotermiske reservoirformationer i Danmark. - Varv 1979, 2 , pp. 41-49.

Michelsen, O. \& Bertelsen, F. 1979: Geotermiske reservoirformationer i den danske lagserie. - Danm. geol. Unders., Årbog 1978, pp. 151-164.

Michelsen, O., Bertelsen, F., Priisholm, S., Holm, L., Gosk, E. \& Laier, T. 1978: Geotermisk Energi i Danmark? - Varv 1978, 4, pp. 105-115.

Nygaard, E. 1980: Zechstein carbonatbjergarterne syd for Ringkøbing-Fyn Højderyggen i Jylland. - Danm. geol. Unders., Upubl. rapport, $9 \mathrm{p}$.

Poulsen, Chr. 1967: The Lower Cambrian from Slagelse No. 1, Western Sealand. - Danm. geol. Unders., II række, 93, 27 p.

Poulsen, Chr. 1974: Further contributions to the knowledge of the Palacozoic of Slagelse No. 1, Western Sealand. - Danm. geol. Unders., II række, 101, 42 p.

Poulsen, K. D. 1979: Varmeledningsevne for porøse geologiske materialer med speciel henblik på kalksten. - Upubl. specialeopgave, Lab. for Geofysik, Aarhus Univ., 123 p.

Priisholm, S. 1976: Lithologisk beskrivelse og tolkning af juralagserien i boringerne Oddesund, Rødding, Skive, Kvols, Hyllebjerg. - Danm. geol. Unders. Nord-projekt. Upubl. rapport 2, 8 p.

Priisholm, S. 1976: Log-korrelation og lithologisk beskrivelse af lithostratigrafiske enheder i nedre kridt. Oddesund, Rødding, Skive, Kvols, Hyllebjerg. - Danm. geol. Unders., Nord-Projekt. Upubl. rapport 3, $5 \mathrm{p}$.

Priisholm, S. 1978: Reservoir parameters of the Haldager Sand Member, Haldager Formation, in the wells Hyllebjerg 1, Skive 1, Hobro 1. - Danm. geol. Unders., confidential rep.

Priisholm, S. \& Michelsen, O. 1978: The use of porosity logs in lithology determination, lithostratigraphy and basin analysis. Danm. geol. Unders., Årbog 1977, pp. 89-100.

Radwanski, A. 1975: Det Dansk-Polske Trug - Dets geotektoniske baggrund, sedimentationshistorie og senere tektonik. Dansk geol. Foren. Årsskrift 1974, pp. 39-41.

Rasmussen, L. B., Baartman, J. C., Henriksen, S. E., Kristoffersen, F. N., Dinesen, A., Bang, I., Stenestad, E., Buch, A. Christensen, O. B., Michelsen, O., Hansen, T. J. \& Jacobsen, F. L. 1973: Dybdeboringen Nøvling Nr. 1 i Midtjylland. Resultaterne af de geologiske undersøgelser. - Danm. geol. Unders., III rakke, 40, $164 \mathrm{p}$.

Rasmussen, L. B., Dinesen, A., Henriksen, S. E., Bang, I., Stenestad, E., Buch, A., Christensen, O. B., Michelsen, O. \& Jacobsen, F. L. 1971: Dybdeboringen Rønde Nr. 1 på Djursland. Resultaterne af de geologiske undersøgelser. - Danm. geol. Unders., III række, 39, $123 \mathrm{p}$.

Richardson, S. W. \& Oxburgh, E. R. 1979: The heat flow field in mainland UK. - Nature 282, pp. 565-567. 
Saxov, S. 1977: Review of temperature and heat flux in Denmark. - EC Seminar on geothermal energy, Brussels, Dec. 1977, pp. 79-97.

Saxov, S. (ed.) 1979: Compilation of temperature, geological, hydrogeological and geochemical data in Denmark. - A first stage survey at the geothermal potential. - EUR 6384 EN (MF), Luxembourg.

Saxov, S. 1980: Geotermisk energi, Symposium om Danmarks energiproblemer 1979. - Samfundsvidenskabeligt forlag, pp. 187-194.

Saxov, S., Balling, N., Breiner, N., Kristiansen, J. I. \& Poulsen, K.
D. 1978: Geothermal Conductivity Equipment: Measurements in Situ and in the Laboratory. - Nordic Symposium on Geothermal Energy, Göteborg, pp. 142-150.

Skjernaa, A. G. 1979: Numerisk løsning af varmeledningsligningen med materialetransport ved hjælp af en pseudo-spektral metode. - Upubl. specialeopgave, Lab. for Geofysik, Aarhus Universitet, $135 \mathrm{p}$

Sorgenfrei, T. 1966: Strukturgeologischer Bau von Dänemark. Z. Geol. 15, pp. 641-660.

Sorgenfrei, T. \& Buch, A. 1964: Deep Tests in Denmark 1935-1959. - Danm. geol. Unders., III række, 36, 146 p. 


\section{Appendix 1}

Tabel over dybder, tykkelser,
porøsiteter og permeabiliteter.

Table of depths, thicknesses, porosities, and permeabilities.

\section{Generelle bemarkninger}

Dybder og tykkelser er baseret på petrofysiske borehulsmålinger - logs.

+ efter tykkelse eller net sand betyder, at lagserien ikke er gennemboret.

A lagserien er klassificeret som Skagerrak Formation (Bertelsen 1980), men medregnes her, ud fra reservoirkaraktererne, til Bunter Sandsten Formation eller Gassum Formationen, respektivt.
Ringe Beds, medregnes her til Tønder Formationen.

" net sand tykkelsen inkluderer Ørslev Formationens sandlag.

$\oplus$ net sand tykkelsen inkluderer Falster Formationens sandlag.

? angivelse behæftet med væsentlig usikkerhed.

$S$ porøstitet baseret på SP-log. Usikker, ofte for høj.

F porøsitet baseret på FDC-log.

$\mathrm{N}$ porøsitet baseret på CNL-log.

I Porøsitet baseret på ITT-log. Behæftet med nogen usikkerhed.

$\mathrm{C}$ porøsitet, målt på et begrænset kernemateriale.

$G$ luftpermeabilitet, målt på et begrænset kernemateriale.

L væskepermeabilitet, målt på et begrænset kernemateriale.

PAL $Æ O Z O I K U M$

\begin{tabular}{|c|c|c|c|c|c|c|}
\hline Boring & $\begin{array}{c}\text { Dybde u. } \\
\text { havniveau } \\
\text { meter }\end{array}$ & $\begin{array}{l}\text { Midt dybde } \\
\text { meter }\end{array}$ & $\begin{array}{l}\text { Tykkelse } \\
\text { meter }\end{array}$ & $\begin{array}{l}\text { Net sand } \\
\text { meter }\end{array}$ & $\begin{array}{l}\text { Porøsitet } \\
\%\end{array}$ & $\begin{array}{l}\text { Permeabilitet } \\
\mathrm{mD}\end{array}$ \\
\hline \multicolumn{7}{|c|}{ Zechstein 3 kalksten } \\
\hline Arnum 1 & $1711-1761$ & 1742 & 39 & & $\mathrm{C}-8$ & $\mathrm{G}-0,1$ \\
\hline Hønning 1 & $2103-2148$ & 2126 & 45 & & $\mathrm{C}-2$ & $\mathrm{G}-0,3$ \\
\hline Tonder 1 & $2387-2393$ & 2390 & 6 & & & \\
\hline Tønder 2 & $2655-2660$ & 2567 & 4 & & $\mathrm{C}-19$ & $\mathrm{G}-1,5$ \\
\hline Åbenrå 1 & $1930-2057$ & 1955 & 27 & & $C-6$ & $\mathrm{G}-0,02$ \\
\hline \multicolumn{7}{|c|}{ Zechstein 2 kalksten } \\
\hline Hønning 1 & $2248-2254$ & 2251 & 6 & & & \\
\hline Tønder 1 & $3084-3111$ & 3097 & 27 & & $\mathrm{C}-3$ & G-1 \\
\hline Tonder 2 & $2981-3009$ & 2995 & 28 & & $\mathrm{C}-3$ & $\mathrm{G}-0,1$ \\
\hline Åbenrå 1 & $2041-2071$ & 2067 & 30 & & $\mathrm{C}-15$ & $\mathrm{G}-0,2$ \\
\hline \multicolumn{7}{|c|}{ Zechstein 1 øve kalksten } \\
\hline Hønning 1 & $2330-2374$ & 2332 & 44 & & $\mathrm{C}-16$ & $\mathrm{G}-4$ \\
\hline Tønder 2 & $3038-3043$ & 3040 & 5 & & $C-22$ & $G-440$ \\
\hline Åbenrå 1 & $2151-2183$ & 2178 & 32 & & $\mathrm{C}-8$ & G-1 \\
\hline \multicolumn{7}{|c|}{ Zechstein 1 nedre kalksten } \\
\hline Hønning 1 & $2422-2444$ & 2433 & 22 & & $\mathrm{C}-15$ & $\mathrm{G}-2$ \\
\hline Tønder 2 & $3051-3070$ & 3060 & 19 & & $\mathrm{C}-7$ & $\mathrm{G}-0,8$ \\
\hline Åbenrå 1 & $2238-2280$ & 2270 & 42 & & $\mathrm{C}-15$ & $\mathrm{G}-10$ \\
\hline \multicolumn{7}{|c|}{ Rotliegendes sandsten } \\
\hline Ringe 1 & $1194-1363+$ & $1279+$ & $169+$ & 100 & $\mathrm{C}-10$ & $\mathrm{G}-4$ \\
\hline Rødby 2 & $2674-2860$ & 2767 & 186 & & $\mathrm{C}-7$ & $\mathrm{G}-5$ \\
\hline Rønde 1 & $4822-4919$ & 4871 & 97 & & & \\
\hline Tønder 2 & $3071-3200+$ & $3133+$ & $124+$ & & C-9 & $\mathrm{G}-4$ \\
\hline Ørslev 1 & $1803-2028$ & 1916 & 225 & 50 & F/I-17 & \\
\hline \multicolumn{7}{|c|}{ Karbon kalksten } \\
\hline Ørslev 1 & $2028-2551+$ & $2290+$ & $523+$ & & $\mathrm{F} / \mathrm{I}-8$ & \\
\hline \multicolumn{7}{|c|}{ Kambrisk kvartsitisk sandsten } \\
\hline Slagelse 1 & $2928-2934+$ & $2931+$ & $6+$ & $6+$ & $C-4$ & G-3 \\
\hline
\end{tabular}


BUNTER SANDSTEN FORMATION

\begin{tabular}{|c|c|c|c|c|c|c|}
\hline Boring & $\begin{array}{l}\text { Dybde u. } \\
\text { havniveau } \\
\text { meter }\end{array}$ & $\begin{array}{l}\text { Midt dybde } \\
\text { meter }\end{array}$ & $\begin{array}{l}\text { Tykkelse } \\
\text { meter }\end{array}$ & $\begin{array}{l}\text { Net sand } \\
\text { meter }\end{array}$ & $\begin{array}{l}\text { Porøsitet } \\
\%\end{array}$ & $\begin{array}{l}\text { Permeabilitet } \\
\mathrm{mD}\end{array}$ \\
\hline $\begin{array}{l}\text { Arnum } 1 \\
\text { Børglum } 1 \\
\text { Fjerritslev } 1 \\
\text { Fjerritslev } 2 \\
\text { Flybjerg } 1\end{array}$ & $1377-1502$ & 1440 & 125 & 9 & $S-16, C-31$ & $\mathrm{G}-100$ \\
\hline Frederikshavn 1 & $971-1277^{*}$ & 1124 & 306 & $50 ?$ & & $S-17$ \\
\hline Frederikshavn 2 & 948-1064* & 1006 & $116+$ & & & \\
\hline Frederikshavn 3 & 924-998* & $\begin{array}{r}961 \\
3036\end{array}$ & $\begin{array}{l}74+ \\
694\end{array}$ & $690,736^{\prime \prime}$ & $C-15$ & $\mathrm{G}-100$ \\
\hline $\begin{array}{l}\text { Gassum } 1 \\
\text { Glamsbjerg } 1\end{array}$ & $2689-3383$ & 3036 & & & & \\
\hline $\begin{array}{l}\text { Grindsted } 1 \\
\text { Haldager } 1 \\
\text { Harte } 1 \\
\text { Hobro } 1 \\
\text { Horsens } 1 \\
\text { Hyllebjerg } 1\end{array}$ & $1401-1458$ & 1430 & 57 & 40 & $\mathrm{I}-28$ & \\
\hline $\begin{array}{l}\text { Hønning } 1 \\
\text { Kvols } 1 \\
\text { Lavø } 1 \\
\text { Linde } 1\end{array}$ & $1560-1743$ & 1653 & 183 & 40 & $\mathrm{~S}-27 / \mathrm{C}-29$ & $\mathrm{G}-1500$ \\
\hline $\begin{array}{l}\text { Mors } 1 \\
\text { Nøvling } 1\end{array}$ & $\begin{array}{l}4367-5303 \\
3126-3171\end{array}$ & $\begin{array}{l}4835 \\
3149\end{array}$ & $\begin{array}{c}936+ \\
45\end{array}$ & $\begin{array}{c}750,900^{\prime \prime} \\
0 ?\end{array}$ & $\mathrm{~F}-0, \mathrm{I}-6, \mathrm{C}-7$ & $7 \mathrm{G}-10$ \\
\hline Oddesund 1 & & & & & & \\
\hline Ringe 1 & $1063-1075$ & 1069 & 12 & & & \\
\hline $\begin{array}{l}\text { Rødby } 1 \\
\text { Rødby } 2\end{array}$ & $1125-1382$ & 1254 & 256 & 45 & S $-38, C-24$ & G-75 \\
\hline $\begin{array}{l}\text { Rødby } 2 \\
\text { Rødding } 1\end{array}$ & $1096-1337$ & 1217 & 240 & & & \\
\hline Rødekro 1 & $1331-1410$ & 1371 & 79 & 19 & S-33 & \\
\hline Rønde 1 & $4013-4591$ & 4302 & 578 & $280,330^{\prime \prime}$ & $\mathrm{F} / 1-8$ & \\
\hline Skive 1 & $563-619 *$ & 591 & & & & \\
\hline $\begin{array}{l}\text { Slagelse } 1 \\
\text { Thisted } 1\end{array}$ & $1824-2016$ & 1920 & 192 & 74 & $\mathrm{~N}-35 ?$ & \\
\hline Tønder 1 & $1606-1808$ & 1707 & 203 & 35 & & \\
\hline Tønder 2 & $1924-2100$ & 2012 & 176 & & & \\
\hline Uglev 1 & & & & & & \\
\hline Ullerslev 1 & & & & & & \\
\hline Vedsted 1 & & & & & & \\
\hline Vemb 1 & & & & & & \\
\hline Vinding 1 & & & & & & \\
\hline Voldum 1 & & & & & $\mathrm{~F} / \mathrm{N}-25$ & \\
\hline Ørslev 1 & 1064-1181 & 1123 & 117 & 19 & & \\
\hline Åbenrå 1 & $1467-1579$ & 1523 & 112 & & & \\
\hline
\end{tabular}


TØNDER FORMATION

\begin{tabular}{|c|c|c|c|c|c|c|}
\hline Boring & $\begin{array}{l}\text { Dybde u. } \\
\text { havniveau } \\
\text { meter }\end{array}$ & $\begin{array}{l}\text { Midt dybde } \\
\text { meter }\end{array}$ & $\begin{array}{l}\text { Tykkelse } \\
\text { meter }\end{array}$ & $\begin{array}{l}\text { Net sand } \\
\text { meter }\end{array}$ & $\begin{array}{l}\text { Porøsitet } \\
\%\end{array}$ & $\begin{array}{l}\text { Permeabilitet } \\
\mathrm{mD}\end{array}$ \\
\hline $\begin{array}{l}\text { Arnum } 1 \\
\text { Barglum } 1 \\
\text { Fjerritslev } 1 \\
\text { Fjerritslev } 2 \\
\text { Flyvbjerg } 1 \\
\text { Frederikshavn } 1 \\
\text { Frederikshavn } 2 \\
\text { Frederikshavn } 3\end{array}$ & $953-1103$ & 1028 & 150 & 22 & $S-41$ & \\
\hline $\begin{array}{l}\text { Gassum } 1 \\
\text { Glamsbjerg } 1\end{array}$ & $2022-2263$ & 2143 & 241 & 24 & $\mathrm{C}-28$ & G-1000 \\
\hline $\begin{array}{l}\text { Grindsted } 1 \\
\text { Haldager } 1 \\
\text { Harte } 1 \\
\text { Hobro } 1 \\
\text { Horsens } 1 \\
\text { Hyllebjerg } 1\end{array}$ & $1007-1176$ & 1092 & 169 & 34 & $>I-40$ & \\
\hline $\begin{array}{l}\text { Hønning I } \\
\text { Kvols } 1 \\
\text { Lavø 1 } \\
\text { Linde } 1\end{array}$ & $1092-1261$ & 1177 & 169 & 33 & S-31 & \\
\hline $\begin{array}{l}\text { Mors } 1 \\
\text { Nøvling } 1 \\
\text { Oddesund } 1 \\
\text { Ringe 1 } \\
\text { Rødby } 1 \\
\text { Rødby } 2 \\
\text { Rødding } 1\end{array}$ & $\begin{array}{l}3480-3719 \\
2661-2969\end{array}$ & $\begin{array}{l}3600 \\
2815\end{array}$ & $\begin{array}{l}238 \\
308\end{array}$ & $85,170^{\oplus}$ & $F-11$ & \\
\hline Rødekro 1 & $1025-1139$ & 1082 & 114 & 25 & $S-45$ & \\
\hline $\begin{array}{l}\text { Rønde } 1 \\
\text { Skagen } 1 \\
\text { Skagen } 2 \\
\text { Skive } 1\end{array}$ & $3415-3656$ & 3536 & 241 & 100 & $\mathrm{~F}-10$ & \\
\hline $\begin{array}{l}\text { Slagelse } 1 \\
\text { Thisted } 1\end{array}$ & $1297-1590^{\prime}$ & 1444 & 293 & $20 ?$ & & \\
\hline $\begin{array}{l}\text { Tønder } 1 \\
\text { Tønder } 2\end{array}$ & $\begin{array}{l}1050-1255 \\
1326-1581\end{array}$ & $\begin{array}{l}1153 \\
1454\end{array}$ & $\begin{array}{l}204 \\
255\end{array}$ & $\begin{array}{l}21 \\
12\end{array}$ & $\begin{array}{l}\text { S }-33, C-40 \\
\text { S-30 }\end{array}$ & \\
\hline $\begin{array}{l}\text { Uglev } 1 \\
\text { Ullerslev } 1 \\
\text { Vedsted } 1 \\
\text { Vemb } 1\end{array}$ & & & & & & \\
\hline $\begin{array}{l}\text { Vinding } 1 \\
\text { Voldum } 1 \\
\text { Orslev } 1\end{array}$ & $1921-2105 ?$ & $2013 ?$ & $184 ?$ & & & \\
\hline Åbenrå 1 & $1041-1179$ & 1110 & 138 & & & \\
\hline
\end{tabular}




\section{GASSUM FORMATION}

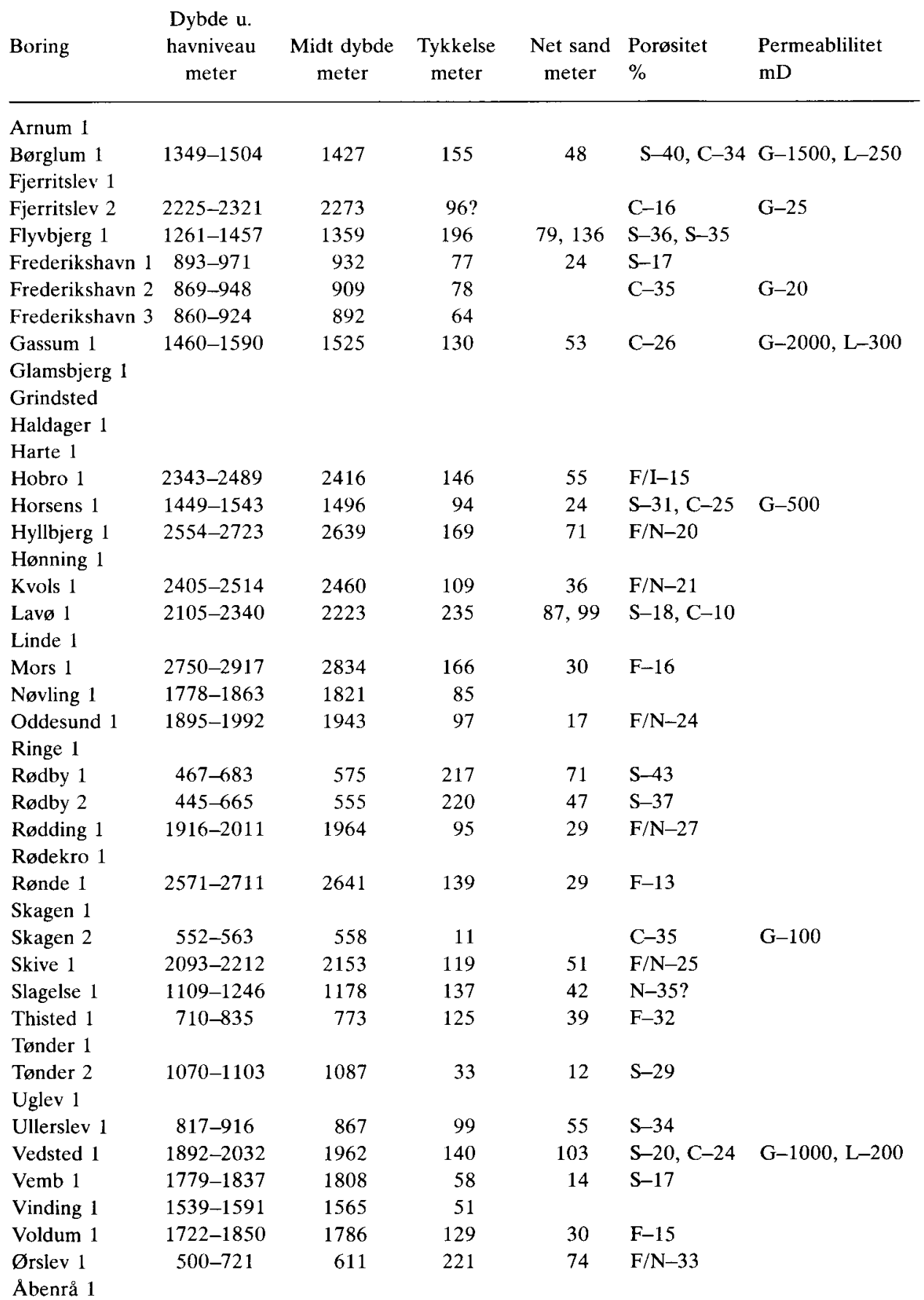


HALDAGER SAND

\begin{tabular}{|c|c|c|c|c|c|c|}
\hline Boring & $\begin{array}{l}\text { Dybde } \mathrm{u} . \\
\text { havniveau } \\
\text { meter }\end{array}$ & $\begin{array}{l}\text { Midt dybde } \\
\text { meter }\end{array}$ & $\begin{array}{l}\text { Tykkelse } \\
\text { meter }\end{array}$ & $\begin{array}{l}\text { Net sand } \\
\text { meter }\end{array}$ & $\begin{array}{l}\text { Porøsitet } \\
\%\end{array}$ & $\begin{array}{l}\text { Permeabilitet } \\
\mathrm{mD}\end{array}$ \\
\hline \multicolumn{7}{|l|}{ Arnum 1} \\
\hline $\begin{array}{l}\text { Børglum } 1 \\
\text { Fjerritslev } 1\end{array}$ & $1024-1053$ & 1039 & 29 & 18 & S-31 & \\
\hline Fjerritslev 2 & $1280-1314$ & 1297 & 35 & 15 & $\mathrm{~S}-16$ & \\
\hline Flyvbjerg 1 & $944-998$ & 971 & 54 & 40 & $S-31$ & \\
\hline Frederikshavn 1 & $689-724$ & 707 & 35 & 16 & $\mathrm{~S}-13$ & \\
\hline Frederikshavn 2 & $650-696$ & 673 & 46 & & & \\
\hline \multicolumn{7}{|c|}{ Frederikshavn 3} \\
\hline \multicolumn{7}{|l|}{ Gassum 1} \\
\hline \multicolumn{7}{|l|}{ Glamsbjerg 1} \\
\hline \multicolumn{7}{|l|}{ Grindsted 1} \\
\hline Haldagaer 1 & $1120-1275$ & 1198 & 154 & 88 & S-24 & \\
\hline Harte 1 & & & & & & \\
\hline Hobro 1 & $1852-1891$ & 1872 & 39 & 20 & $\mathrm{~F}-22$ & \\
\hline Horsens 1 & $1235-1239$ & 1237 & 4 & 5 & $\mathrm{~S}-24$ & \\
\hline $\begin{array}{l}\text { Hyllebjerg } 1 \\
\text { Hønning } 1\end{array}$ & $1885-1894$ & 1890 & 9 & 8 & $\mathrm{~F} / \mathrm{N}-28$ & \\
\hline $\begin{array}{l}\text { Kvols } 1 \\
\text { Lavø } 1 \\
\text { Linde } 1\end{array}$ & $1940-1955$ & 1948 & 15 & 7 & $\mathrm{~F} / \mathrm{N}-25$ & \\
\hline $\begin{array}{l}\text { Mors } 1 \\
\text { Nøvling } 1\end{array}$ & $2015-2137$ & 2076 & 122 & 44 & $\mathrm{~F} / \mathrm{I}-19$ & \\
\hline $\begin{array}{l}\text { Oddesund } 1 \\
\text { Ringe } 1\end{array}$ & $1604-1608$ & 1606 & 4 & 3 & $\mathrm{~F} / \mathrm{N}-28$ & \\
\hline Rødby 1 & & & & & & \\
\hline Rødby 2 & & & & & & \\
\hline Rødding 1 & & & & & & \\
\hline Rødekro 1 & & & & & & \\
\hline Rønde 1 & & & 0 & & & \\
\hline Skagen 1 & & & & & & \\
\hline Skagen 2 & $429-443$ & 436 & 14 & 5 & S-31 & \\
\hline $\begin{array}{l}\text { Skive } 1 \\
\text { Slagelse } 1\end{array}$ & $1690-1702$ & 1696 & 12 & 10 & $\mathrm{~F} / \mathrm{N}-32$ & \\
\hline $\begin{array}{l}\text { Thisted } 1 \\
\text { Tønder } 1\end{array}$ & $569-600$ & 585 & 31 & 13 & F-33 & \\
\hline Tønder 2 & & & & & & \\
\hline $\begin{array}{l}\text { Uglev } 1 \\
\text { Ullerslev } 1\end{array}$ & $873-910$ & 892 & 37 & 18 & $\mathrm{~S}-42, \mathrm{C}-28$ & $\mathrm{G}-600$ \\
\hline Vedsted 1 & $1144-1219$ & 1182 & 75 & 55 & $\mathrm{~S}-36, \mathrm{C}-33$ & G-2000 \\
\hline $\begin{array}{l}\text { Vemb } 1 \\
\text { Vinding } 1\end{array}$ & $1566-1575$ & 1571 & 9 & 8 & S-20 & \\
\hline $\begin{array}{l}\text { Voldum } 1 \\
\text { Ørslev } 1 \\
\text { Åbenrå } 1\end{array}$ & $1358-1388$ & 1373 & 30 & 5 & $F-12$ & \\
\hline
\end{tabular}


FREDERIKSHAVN MEMBER

\begin{tabular}{|c|c|c|c|c|c|c|}
\hline Boring & $\begin{array}{l}\text { Dybde } \mathrm{u} . \\
\text { havniveau } \\
\text { meter }\end{array}$ & $\begin{array}{l}\text { Midt dybde } \\
\text { meter }\end{array}$ & $\begin{array}{l}\text { Tykkelse } \\
\text { meter }\end{array}$ & $\begin{array}{l}\text { Net sand } \\
\text { meter }\end{array}$ & $\begin{array}{l}\text { Porøsitet } \\
\%\end{array}$ & $\begin{array}{l}\text { Permeabilitet } \\
\mathrm{mD}\end{array}$ \\
\hline \multicolumn{7}{|l|}{ Arnum 1} \\
\hline Børglum 1 & $733-957$ & 845 & 224 & 67 & S-31, C-25 & \\
\hline \multicolumn{7}{|l|}{ Fjerritslev 1} \\
\hline Fjerritslev 2 & $1001-1143$ & 1072 & 142 & 0 & 0 & \\
\hline Flyvbjerg 1 & $703-875$ & 789 & 172 & 70 & $S-26, C-40$ & \\
\hline Frederikshavn 1 & $495-629$ & 562 & 134 & & & \\
\hline Frederikshavn 2 & $462-593$ & 528 & 131 & & & \\
\hline \multicolumn{7}{|c|}{ Frederikshavn 3} \\
\hline Gassum 1 & $1020-1121$ & 1071 & 101 & 24 & $S-17, C-30$ & $\mathrm{G}-400$ \\
\hline \multicolumn{7}{|l|}{ Glamsbjerg 1} \\
\hline \multicolumn{7}{|l|}{ Grindsted 1} \\
\hline Haldager 1 & $780-1023$ & 902 & 243 & $21 ?$ & $C-30$ & $\mathrm{G}-1000$ \\
\hline \multicolumn{7}{|l|}{ Harte 1} \\
\hline Hobro 1 & $1741-1823$ & 1782 & 82 & 11 & $\mathrm{~F} / \mathrm{I}-15$ & \\
\hline Horsens 1 & $1168-1230$ & 1199 & 62 & 36 & S-33 & \\
\hline Hyllebjerg 1 & $1663-1810$ & 1737 & 147 & 20 & $\mathrm{~F} / \mathrm{N}-29$ & \\
\hline \multicolumn{7}{|l|}{ Hønning 1} \\
\hline Kvols 1 & $1856-1912$ & 1884 & 56 & 5 & $\mathrm{~F} / \mathrm{N}-29$ & \\
\hline \multicolumn{7}{|l|}{ Lavø 1} \\
\hline Linde 1 & $1097-1128$ & 1113 & 31 & 4 & $\mathrm{~F} / \mathrm{N}-26$ & \\
\hline Mors 1 & $1731-1868$ & 1800 & 137 & 36 & $\mathrm{I}-25$ & \\
\hline Novling 1 & $1325-1425$ & 1375 & 100 & $0 ?$ & & \\
\hline Oddesund 1 & $1487-1556$ & 1522 & 69 & 10 & $\mathrm{~F} / \mathrm{N}-28$ & \\
\hline \multicolumn{7}{|l|}{ Ringe 1} \\
\hline \multicolumn{7}{|l|}{ Rødby 1} \\
\hline \multicolumn{7}{|l|}{ Rødby 2} \\
\hline \multicolumn{7}{|l|}{ Rødding 1} \\
\hline \multicolumn{7}{|l|}{ Rødekro 1} \\
\hline Rønde 1 & $2008-2058$ & 2033 & 50 & 18 & $\mathrm{~F} / \mathrm{I}-20$ & \\
\hline \multicolumn{7}{|l|}{$\begin{array}{l}\text { Rønde } 1 \\
\text { Skagen } 1\end{array}$} \\
\hline Skagen 2 & $193-385$ & 289 & 192 & 71 & $S-39$ & \\
\hline Skive 1 & $1559-1629$ & 1594 & 70 & 4 & $\mathrm{~F} / \mathrm{N}-25$ & \\
\hline \multicolumn{7}{|l|}{ Slagelse 1} \\
\hline Thisted 1 & $?$ & & & & & \\
\hline \multicolumn{7}{|l|}{$\begin{array}{l}\text { Thisted } 1 \\
\text { Tønder } 1\end{array}$} \\
\hline \multicolumn{7}{|l|}{$\begin{array}{l}\text { lønder } 1 \\
\text { Tønder } 2\end{array}$} \\
\hline Uglev 1 & $?$ & & & & & \\
\hline \multicolumn{7}{|l|}{ Ullerslev 1} \\
\hline Vedsted 1 & $836-1071$ & 954 & 235 & 19 & $S-35$ & \\
\hline Vemb 1 & $?$ & & & & & \\
\hline \multicolumn{7}{|l|}{ Vinding 1} \\
\hline Voldum 1 & $1278-1344$ & 1311 & 66 & 32 & $F-17$ & \\
\hline Ørslev 1 & & & & & & \\
\hline Åbenrå 1 & & & & & & \\
\hline
\end{tabular}




\section{Appendix 2}

\section{Tabel og figurer over varmeledningsevne og varmeproduktion.}

Table and figures of thermal conductivity and heat production.

\section{Varmeledningsevne}

$\mathrm{K}$ angiver varmeledningsevnen for vandmættet materiale bestemt på grundlag af målinger. $\mathrm{K}_{\mathrm{s}}$ er den beregnede værdi for materialets faste partikler bestemt via $\mathrm{K}$ og den målte porøsitetsværdi $\varnothing$.

(Tallene i parentes angiver værdier målt på cuttings).

\begin{tabular}{|c|c|c|c|c|c|c|}
\hline $\begin{array}{l}\text { Formation eller } \\
\text { tidsafsnit }\end{array}$ & $\begin{array}{l}\text { Member eller } \\
\text { tidsafsnit }\end{array}$ & Boring & Bjergart & $\varnothing$ & $\begin{array}{c}\mathrm{K} \\
\left(\mathrm{W} \mathrm{\textrm {m } ^ { - 1 } \mathrm { K } ^ { - 1 }}\right)\end{array}$ & $\begin{array}{c}\mathrm{K}_{\mathrm{s}} \\
\left(\mathrm{W} \mathrm{m}^{-1} \mathrm{~K}^{-1}\right)\end{array}$ \\
\hline Tertiær & n. eocæn & Tinglev 1 & siltsten & 0.42 & 1.52 & 2.93 \\
\hline- & paleocæn & Tinglev 1 & lersten & 0.43 & 1.60 & 3.30 \\
\hline- & n. oligocæn & Viborg 5 & ler & 0.49 & 1.39 & 3.09 \\
\hline- & n. eocæn & - & - & 0.50 & 1.40 & 3.26 \\
\hline- & ø. paleocæn & - & - & 0.51 & 1.34 & 3.04 \\
\hline- & m. paleocæn & - & - & 0.47 & 1.40 & 2.97 \\
\hline- & paleocæn & Viborg 1 & - & 0.46 & 1.56 & 3.47 \\
\hline- & - & Vinding 1 & sand & 0.45 & 1.71 & 4.00 \\
\hline- & - & - & lerskifer (sand) & 0.56 & 1.41 & 4.07 \\
\hline- & ø. oligocæn & - & sand & 0.45 & 1.74 & 4.16 \\
\hline- & m. oligocæn & - & ler & 0.53 & 1.48 & 4.09 \\
\hline- & n. eocæn & - & lersten & 0.59 & 1.46 & 5.07 \\
\hline- & paleocæn & - & lerskifer & 0.55 & 1.20 & 2.79 \\
\hline$\varnothing$. Kridt & maastr.-campanien & Gassum 1 & skrivekridt & 0.36 & 1.70 & 3.01 \\
\hline- & - & - & - & 0.34 & 1.80 & 3.17 \\
\hline- & - & - & - & 0.33 & 1.86 & 3.25 \\
\hline- & - & - & - & 0.33 & 1.84 & 3.18 \\
\hline- & - & - & - & 0.32 & 1.78 & 2.96 \\
\hline- & - & - & - & 0.32 & 1.85 & 3.14 \\
\hline- & - & - & - & 0.31 & 1.90 & 3.14 \\
\hline- & campanien & Gassum 1 & skrivekridt & 0.22 & 2.07 & 2.96 \\
\hline- & santonien & - & - & 0.18 & 2.21 & 2.94 \\
\hline- & - & - & - & 0.16 & 2.37 & 3.07 \\
\hline- & - & - & - & 0.16 & 2.41 & 3.11 \\
\hline- & - & - & kalksten & 0.16 & 2.08 & 2.63 \\
\hline- & - & - & - & 0.16 & 2.12 & 2.68 \\
\hline- & maastr.-coniacien & Horsens 1 & - & 0.14 & 2.53 & 3.22 \\
\hline- & coniacien & Lavø 1 & - & 0.10 & 2.60 & 3.03 \\
\hline- & - & - & - & 0.07 & 2.70 & 3.02 \\
\hline - & turonien & - & - & 0.05 & 2.69 & 2.93 \\
\hline- & maastr.-campanien & Rønnebjerg 1 & skrivekridt & 0.42 & 1.55 & 3.08 \\
\hline- & - & - & - & 0.41 & 1.57 & 3.00 \\
\hline- & - & - & - & 0.35 & 1.67 & 2.85 \\
\hline- & campanien & - & - & 0.35 & 1.63 & 2.78 \\
\hline- & - & - & - & 0.31 & 1.91 & 3.21 \\
\hline
\end{tabular}




\begin{tabular}{|c|c|c|c|c|c|c|}
\hline $\begin{array}{l}\text { Formation eller } \\
\text { tidsafsnit }\end{array}$ & $\begin{array}{l}\text { Member eller } \\
\text { tidsafsnit }\end{array}$ & Boring & Bjergart & $\varnothing$ & 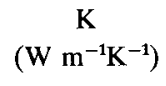 & $\begin{array}{c}\mathrm{K}_{\mathrm{s}} \\
\left(\mathrm{W} \mathrm{m}^{-1} \mathrm{~K}^{-1}\right)\end{array}$ \\
\hline - & - & - & - & 0.40 & 1.61 & 3.04 \\
\hline- & - & - & - & 0.35 & 1.61 & 2.70 \\
\hline - & - & - & - & 0.35 & 1.75 & 3.05 \\
\hline- & - & - & - & 0.38 & 1.60 & 2.92 \\
\hline- & - & - & - & 0.33 & 1.80 & 3.04 \\
\hline - & - & - & - & 0.32 & 1.85 & 3.10 \\
\hline - & santonien & - & kalksten & 0.22 & 2.21 & 3.15 \\
\hline- & - & - & - & 0.21 & 2.34 & 3.32 \\
\hline - & - & - & - & 0.20 & 2.27 & 3.16 \\
\hline - & santonien & Rønnebjerg 1 & kalksten & 0.21 & 2.31 & 3.27 \\
\hline - & cenomanien & - & skifer (kalk) & 0.18 & 2.31 & 3.09 \\
\hline- & turonien & Rønnebjerg 2 & mergelsten & 0.33 & 1.76 & 2.99 \\
\hline- & maastr.-campanien & Svenstrup 1 & skrivekridt & 0.46 & 1.45 & 3.01 \\
\hline - & - & - & - & 0.42 & 1.52 & 2.95 \\
\hline - & santonien & - & kalksten & 0.25 & 2.11 & 3.20 \\
\hline- & & Vemb 1 & skrivekridt & 0.43 & 1.57 & 3.27 \\
\hline- & danien & Vinding 1 & - & 0.37 & 1.75 & 3.27 \\
\hline- & santonien & - & - & 0.22 & 2.24 & 3.20 \\
\hline - & - & - & - & 0.15 & 2.62 & 3.36 \\
\hline- & cenomanien & Haldager 1 & mergelsten & 0.22 & 2.25 & 3.24 \\
\hline- & santonien & Uglev 1 & kalksten & 0.17 & 2.22 & 2.90 \\
\hline- & - & - & - & 0.16 & 2.35 & 3.03 \\
\hline N. kridt & & Arnum 1 & finsandsten & 0.35 & 2.06 & 3.96 \\
\hline- & & Børglum 1 & lersten & 0.42 & 2.57 & 7.21 \\
\hline- & & - & - & 0.42 & 2.14 & 5.24 \\
\hline- & & - & finsand (ler) & 0.43 & 2.21 & 5.75 \\
\hline- & & - & - & 0.34 & 2.47 & 5.12 \\
\hline - & & Fjerritslev 2 & lersten & 0.48 & 1.37 & 2.91 \\
\hline- & & Gassum 1 & lerskifer & $(0.55)$ & $(1.25)$ & 3.08 \\
\hline- & & Haldager 1 & lersten (silt) & 0.45 & 1.50 & 3.08 \\
\hline- & & - & - & 0.47 & 1.42 & 3.06 \\
\hline- & & - & - & 0.32 & 1.34 & 1.95 \\
\hline- & & Lavø 1 & finsandsten & 0.07 & 2.73 & 3.05 \\
\hline- & & - & sandsten & 0.17 & 3.61 & 5.19 \\
\hline- & & - & - & 0.23 & 3.66 & 6.16 \\
\hline - & & Rødby 1 & ler & 0.51 & 1.23 & 2.57 \\
\hline- & & Rønnebjerg 1 & lerskifer & 0.35 & 1.67 & 2.87 \\
\hline - & & - & lerskifer (sand) & 0.48 & 1.56 & 3.68 \\
\hline- & & Uglev 1 & lersten & 0.43 & 1.85 & 4.21 \\
\hline- & & - & - & 0.55 & 1.73 & 6.23 \\
\hline- & & Vedsted 1 & - & 0.45 & 1.81 & 4.44 \\
\hline- & & Vinding 1 & ler & 0.23 & 2.06 & 2.99 \\
\hline- & & - & sandsten & 0.32 & 2.62 & 5.14 \\
\hline Bream & Frederikshavn & Børglum 1 & sandsten & 0.35 & 3.94 & 7.36 \\
\hline- & - & - & siltsten & 0.26 & 1.94 & 2.92 \\
\hline - & - & Fjerritslev 1 & lersten & 0.11 & 2.08 & 2.42 \\
\hline - & - & $-\quad 2$ & finsandsten (ler) & 0.20 & 2.47 & 3.51 \\
\hline- & - & Gassum 1 & sandsten & 0.23 & 2.90 & 4.62 \\
\hline- & - & - & - & 0.40 & 2.32 & 5.58 \\
\hline- & - & - & - & 0.12 & 3.13 & 3.89 \\
\hline- & - & - & - & 0.05 & 4.13 & 4.61 \\
\hline- & - & - & - & 0.06 & 4.20 & 4.70 \\
\hline- & - & - & - & 0.28 & 3.12 & 4.82 \\
\hline- & - & - & - & 0.38 & 2.43 & 5.71 \\
\hline- & - & Haldager 1 & lersten (silt) & 0.33 & 1.87 & 3.27 \\
\hline- & - & - & - & 0.35 & 1.55 & 2.55 \\
\hline- & - & Haldager 1 & lerskifer & $(0.57)$ & $(1.25)$ & 3.17 \\
\hline- & - & - & - & $(0.54)$ & $(1.34)$ & 3.35 \\
\hline
\end{tabular}




\begin{tabular}{|c|c|c|c|c|c|c|}
\hline $\begin{array}{l}\text { Formation eller } \\
\text { tidsafsnit }\end{array}$ & $\begin{array}{l}\text { Member eller } \\
\text { tidsafsnit }\end{array}$ & Boring & Bjergart & $\varnothing$ & 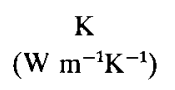 & 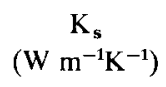 \\
\hline- & - & - & finsandst. (ler) & 0.18 & 3.36 & 4.90 \\
\hline- & - & - & - & 0.40 & 2.20 & 5.18 \\
\hline- & - & - & sandsten & 0.26 & 3.54 & 6.55 \\
\hline- & - & - & - & $(0.48)$ & $(1.83)$ & 5.05 \\
\hline - & - & - & siltsten (ler) & $(0.48)$ & $(1.50)$ & 3.46 \\
\hline- & - & - & sandsten & 0.42 & 2.08 & 5.13 \\
\hline - & $?$ & Vinding 1 & lerskifer & 0.44 & 1.71 & 3.90 \\
\hline Bream & Børglum & Gassum 1 & lerskifer & 0.29 & 2.33 & 4.02 \\
\hline Haldager & Flyvbjerg & Haldager 1 & lersten (sand) & 0.15 & 2.96 & 3.88 \\
\hline- & - & Fjerritslev 2 & lerskifer (sand) & 0.43 & 2.07 & 5.22 \\
\hline- & - & Vedsted 1 & finsandsten & 0.32 & 2.80 & 5.76 \\
\hline Haldager & Haldager sand & Vedsted 1 & sandsten & 0.29 & 3.60 & 7.46 \\
\hline Fjerritslev & F-III & Børglum 1 & Sandsten (silt) & 0.32 & 2.73 & 5.55 \\
\hline- & - & Børglum 1 & lersten & 0.25 & 1.82 & 2.64 \\
\hline- & F-I & - & lerskifer (sand) & 0.24 & 2.65 & 4.22 \\
\hline - & F-III & Fjerritslev 1 & - & 0.49 & 1.86 & 5.34 \\
\hline - & F-I & Fjerritslev 2 & finsandsten & 0.14 & 4.40 & 5.99 \\
\hline - & & Gassum 1 & lerskifer & 0.60 & 1.14 & 2.96 \\
\hline - & & - & lerjernsten & 0.09 & 1.82 & 2.01 \\
\hline- & & - & lerskifer & 0.07 & 3.39 & 3.89 \\
\hline - & & - & lerjernsten & 0.05 & 1.75 & 1.86 \\
\hline- & & - & lerskifer & 0.16 & 3.23 & 4.49 \\
\hline - & F-IV & Haldager 1 & - & 0.29 & 1.56 & 2.27 \\
\hline- & - & - & lerjernsten & 0.14 & 2.53 & 3.20 \\
\hline- & F-I & Horsens 1 & lerskifer (sand) & 0.25 & 3.01 & 5.14 \\
\hline- & F-IV & Vedsted 1 & lersten (sand) & 0.33 & 2.35 & 5.53 \\
\hline- & F-III & Vedsted 1 & lerskifer & 0.28 & 2.53 & 4.41 \\
\hline- & F-I & - & - & 0.18 & 2.78 & 3.81 \\
\hline Gassum & & Børglum 1 & sandsten & 0.30 & 3.10 & 6.14 \\
\hline- & & - & - & 0.31 & 3.31 & 6.98 \\
\hline- & & - & - & 0.31 & 3.29 & 7.05 \\
\hline - & & Fjerritslev 2 & lerskifer (sand) & 0.07 & 3.44 & 3.92 \\
\hline- & $\mathrm{G}-3$ & Gassum 1 & lerskifer & 0.21 & 1.25 & 1.50 \\
\hline- & - & - & sandsten & 0.31 & 2.94 & 6.00 \\
\hline- & - & - & - & 0.28 & 3.11 & 5.89 \\
\hline- & $\mathrm{G}-3 / \mathrm{G}-2$ & - & - & 0.35 & 2.52 & 5.34 \\
\hline - & G-1 & - & lerskifer & 0.30 & 1.76 & 2.75 \\
\hline- & G-1 & - & sandsten & 0.21 & 2.94 & 4.42 \\
\hline- & - & - & - & 0.30 & 2.43 & 4.44 \\
\hline- & - & - & - & 0.29 & 2.61 & 4.72 \\
\hline- & - & - & - & 0.18 & 3.12 & 4.46 \\
\hline- & - & - & - & 0.29 & 2.44 & 4.26 \\
\hline - & & Lavø 1 & finsandsten & 0.10 & 3.51 & 4.23 \\
\hline - & & - & lerskifer & 0.06 & 2.78 & 3.07 \\
\hline - & & Rødby 1 & lersten/finsand & 0.47 & 1.83 & 4.89 \\
\hline- & & - & lersten & 0.40 & 1.54 & 2.84 \\
\hline- & & - & finsand & 0.37 & 3.01 & 7.58 \\
\hline- & & Tønder 2 & finsandsten & 0.26 & 3.17 & 5.73 \\
\hline- & $\mathrm{G}-2$ & Vedsted 1 & sandsten & 0.27 & 3.84 & 7.58 \\
\hline Vinding & & Gassum 1 & lerskifer & 0.06 & 2.32 & 2.54 \\
\hline- & & - & _ (kalk) & 0.13 & 1.89 & 2.23 \\
\hline- & & - & - & 0.13 & 1.65 & 1.92 \\
\hline- & & - & kalkst. kongl. & 0.10 & 2.48 & 2.88 \\
\hline- & & Tønder 2 & kalksten & 0.10 & 2.77 & 3.27 \\
\hline
\end{tabular}




\begin{tabular}{|c|c|c|c|c|c|c|}
\hline $\begin{array}{l}\text { Formation eller } \\
\text { tidsafsnit }\end{array}$ & $\begin{array}{l}\text { Member eller } \\
\text { tidsafsnit }\end{array}$ & Boring & Bjergart & $\varnothing$ & 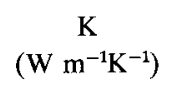 & 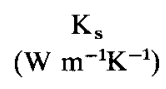 \\
\hline- & & Vinding 1 & lerskifer & 0.24 & 1.61 & 2.20 \\
\hline- & & - & - & 0.16 & 2.11 & 2.65 \\
\hline Oddesund & & Rødby 1 & lersten & 0.26 & 1.71 & 2.47 \\
\hline- & & Tønder 2 & - & 0.25 & 2.16 & 3.27 \\
\hline- & & Ullerslev 1 & - & 0.21 & 2.49 & 3.62 \\
\hline- & & - & - & 0.26 & 1.90 & 2.83 \\
\hline- & & Vinding 1 & sandsten (ler) & 0.17 & 2.33 & 3.05 \\
\hline Tønder & & Gassum 1 & sandsten & 0.12 & 3.55 & 4.51 \\
\hline Falster & & Arnum 1 & finsandsten (kalk) & 0.19 & 2.23 & 3.01 \\
\hline- & & Glamsbjerg 1 & sandsten & 0.31 & 2.49 & 4.71 \\
\hline- & & Ringe 1 & lersten & 0.24 & 1.80 & 2.55 \\
\hline- & & Rødby 1 & - & 0.21 & 2.60 & 3.87 \\
\hline- & & - & lerskifer (kalk) & 0.14 & 2.53 & 3.22 \\
\hline- & & Tender 1 & lersten & 0.20 & 1.46 & 1.86 \\
\hline Ørslev & & Arnum 1 & lersten & 0.41 & 1.65 & 3.26 \\
\hline- & & Gassum 1 & siltsten & 0.17 & 2.86 & 3.94 \\
\hline- & & Rødby 1 & dolomit/anhydrit & 0.02 & 5.15 & 5.42 \\
\hline Bunter & & Arnum 1 & sandsten & 0.34 & 2.33 & 4.71 \\
\hline- & & Gassum 1 & - & 0.20 & 3.65 & 5.69 \\
\hline- & & Rødby 1 & lersten & 0.20 & 2.09 & 2.83 \\
\hline- & & Tønder 1 & - & 0.25 & 2.98 & 3.13 \\
\hline Skagerrak & & Vedsted 1 & sandsten & 0.25 & 3.82 & 7.03 \\
\hline Bunter & & Arnum 1 & lersten & 0.35 & 1.68 & 2.89 \\
\hline Zechstein & & Hønning 1 & dolomit/anhydrit & 0.02 & 6.43 & 6.76 \\
\hline- & & Tønder 1 & stensalt (+anh.) & 0.03 & 6.17 & 6.62 \\
\hline- & & - & anhydrit & 0.05 & 6.20 & 6.95 \\
\hline- & & Tønder 2 & - & 0.03 & 6.09 & 6.50 \\
\hline- & & Uglev 1 & - & 0.03 & 5.57 & 5.90 \\
\hline- & & - & stensalt & 0.03 & 5.48 & 5.79 \\
\hline Rotliegendes & & Rødby 2 & lersten (sand) & 0.06 & 3.71 & 4.14 \\
\hline Perm/eokambrium & & Ringe 1 & sandsten & 0.06 & 3.48 & 3.89 \\
\hline Præ ø. perm & & Hønning 1 & lerskifer & 0.11 & 1.86 & 2.12 \\
\hline Ord./silur & & Slagelse 1 & dolomit & 0.01 & 4.49 & 4.61 \\
\hline- & & - & sandsten & 0.02 & 3.48 & 3.61 \\
\hline
\end{tabular}


Varmeproduktion beregnet på grundlag af målte koncentrationer af uran, thorium og kalium

\begin{tabular}{|c|c|c|c|c|c|c|c|}
\hline $\begin{array}{l}\text { Formation eller } \\
\text { tidsafsnit }\end{array}$ & Bjergart & Boring & $\begin{array}{l}\text { Uran } \\
(\mathrm{ppm})\end{array}$ & $\begin{array}{c}\text { Thorium } \\
\text { ppm) }\end{array}$ & $\begin{array}{c}\text { Kalium } \\
(\%)\end{array}$ & $\begin{array}{c}\text { Masse- } \\
\text { fylde } \\
\left(10^{3} \mathrm{~kg} \mathrm{~m}^{-3}\right)\end{array}$ & $\begin{array}{c}\text { Varme- } \\
\text { produktion } \\
\left(\mu \mathrm{Wm}^{-3}\right)\end{array}$ \\
\hline Eocæn & ler & Viborg 5 & 0.8 & 8.5 & 1.58 & 1.40 & 0.51 \\
\hline Eocan & ler & Viborg 5 & 1.6 & 3.6 & 0.61 & 1.40 & 0.38 \\
\hline$\varnothing$. kridt & skrivekridt & Gassum 1 & 0.4 & 0.9 & 0.18 & 1.78 & 0.12 \\
\hline$\varnothing$. kridt & skrivekridt & Uglev 1 & 0.2 & 0.6 & 0.01 & 2.27 & 0.08 \\
\hline N. kridt & lersten & Uglev 1 & 2.8 & 12.9 & 2.00 & 1.54 & 1.07 \\
\hline Børglum & lersten & Gassum 1 & 3.5 & 16.9 & 1.72 & 1.99 & 1.71 \\
\hline Fjerritslev & lerskifer & Gassum 1 & 2.5 & 14.5 & 2.20 & 2.58 & 1.84 \\
\hline Fjerritslev & lerskifer & Lavø 1 & 2.1 & 14.8 & 2.88 & 2.38 & 1.68 \\
\hline Gassum & sandsten & Gassum 1 & 0.8 & 2.4 & 1.95 & 1.88 & 0.40 \\
\hline Vinding & lerskifer & Gassum 1 & 2.7 & 15.2 & 2.65 & 2.52 & 1.93 \\
\hline Oddesund & lerskifer & Gassum 1 & 3.6 & 9.6 & 3.14 & 2.38 & 1.72 \\
\hline Oddesund & lersten & Tønder 2 & 2.3 & 9.2 & 2.39 & 2.10 & 1.17 \\
\hline Tønder & lerskifer & Gassum 1 & 4.1 & 16.8 & 3.36 & 2.38 & 2.31 \\
\hline Muschelkalk & lersten & Tønder 1 & 2.2 & 7.1 & 1.78 & 2.24 & 1.05 \\
\hline Röt & lersten/siltst. & Gassum 1 & 3.4 & 11.1 & 3.46 & 2.32 & 1.75 \\
\hline Bunter & sandsten & Gassum 1 & 0.8 & 2.3 & 0.88 & 2.12 & 0.36 \\
\hline Bunter & lersten & Tønder 1 & 3.3 & 10.9 & 2.38 & 2.24 & 1.57 \\
\hline Zechstein & stensalt & Uglev 1 & 0.1 & 0.4 & 0.02 & 2.11 & 0.04 \\
\hline Zechstein & dolomit & Tønder 2 & 3.0 & 0.8 & 0.12 & 2.79 & 0.88 \\
\hline Zechstein & anhydrit & Tonder 2 & 0.9 & 0.3 & 0.01 & 2.94 & 0.28 \\
\hline Rotliegendes & lersten & Rødby 2 & 2.6 & 11.1 & 2.36 & 2.63 & 1.67 \\
\hline Ord./Silur & lerskifer & Slagelse 1 & 3.0 & 15.2 & 2.92 & 2.74 & 2.21 \\
\hline
\end{tabular}

(Der er foretaget målinger på yderligere 6 prøver fra Aars 1a. Disse resultater er ikke medtaget her, men anvendt i histogrammet på fig. 5). Massefylden gælder for tørt materiale. 


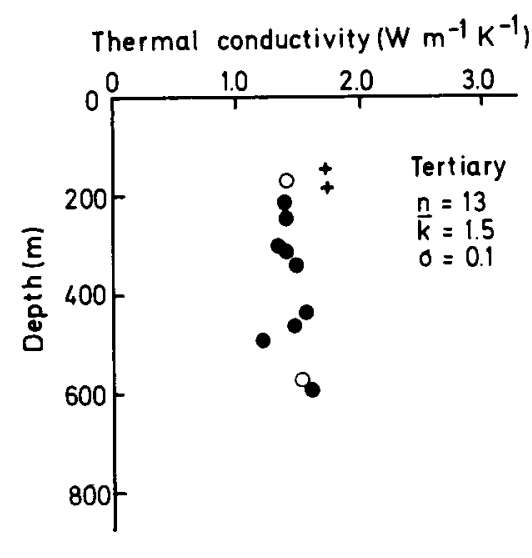

Fig. 1.

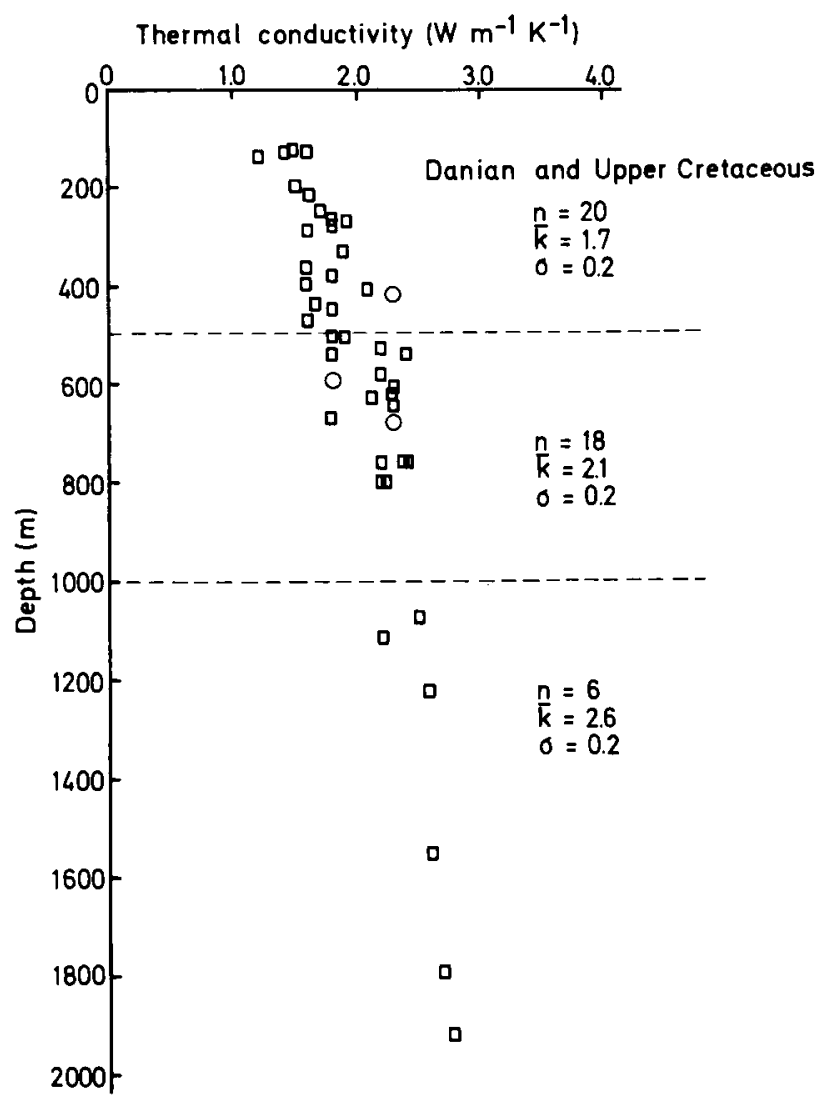

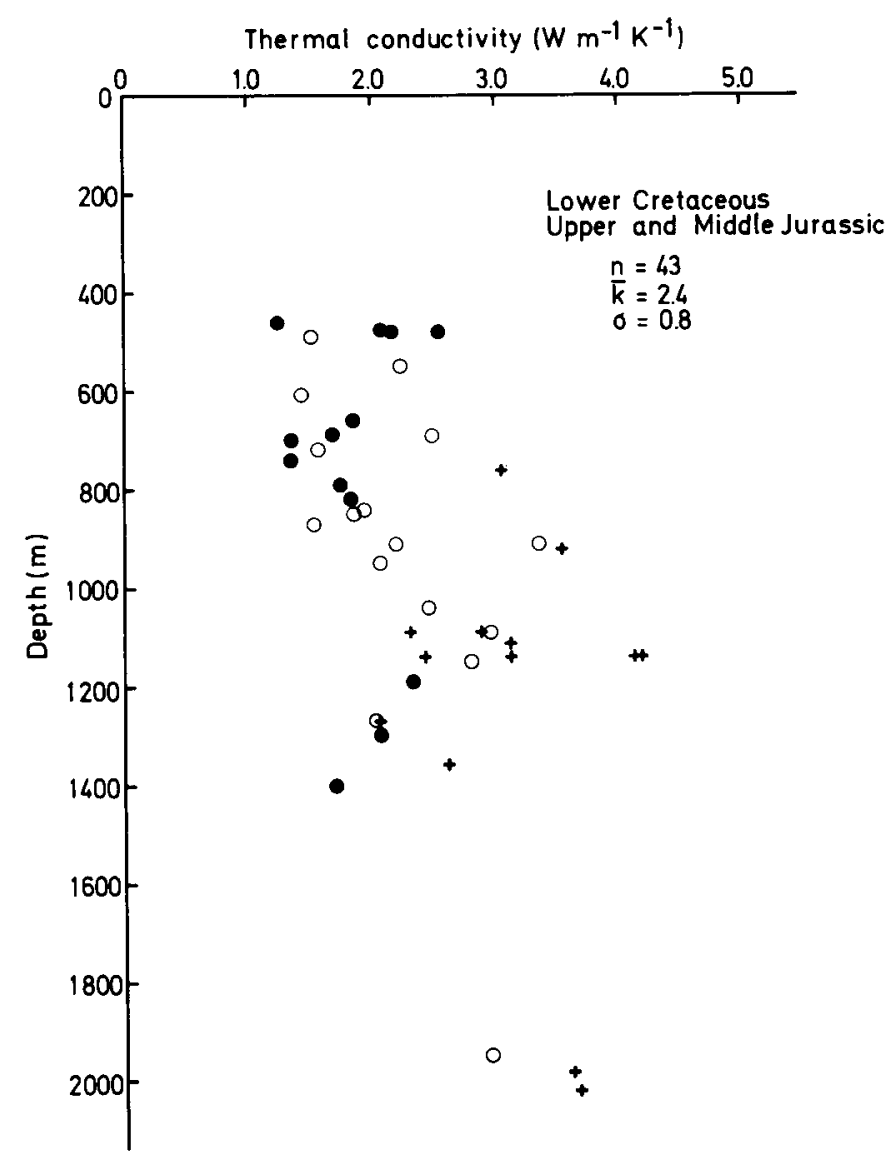

Fig. 3.

Fig. 2. 

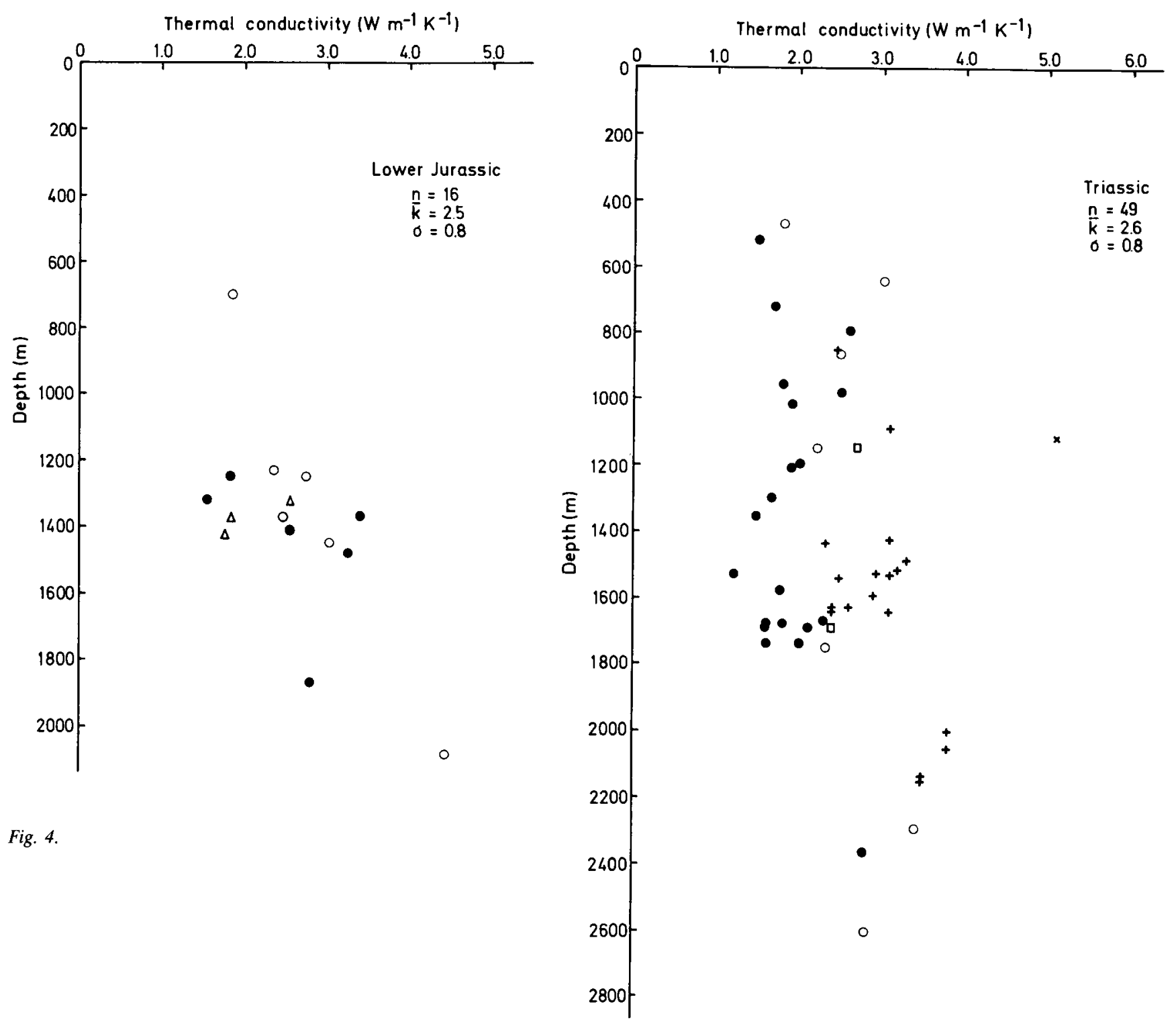

Fig. 5.

Signaturforklaring til figurerne

$\square$ Kalk og kalksten

+ Sand og sandsten

- Ler, lersten og lerskifer

Siltsten, finsandsten, lerede sandsten, sandede lersten og sandede lerskifer

$\triangle$ Lerjernsten

$\times$ Dolomit og anhydrit 


\section{Appendix 3}

\section{Beregningsresultater fra vurderingen af reserverne.}

\section{Computed results from the evaluation of the reserves.}

De vigtigste beregningsresultater fra vurderingen af reserverne er præsenteret i tabel 1-4. I hver tabel er der samlet resultater for ét transmissivitetsniveau og ét fjernvarmetemperaturniveau. Foruden resultaterne for hvert enkelt af de fire områder er der også i tabellerne inkluderet resultater for de fire områder tilsammen. De i denne kolonne angivne effekter, effekt- og udnyttelsesfaktorer samt transmissiviteter er arealvægtede middelværdier.

Følgende resultater er inkluderet i tabellerne:

\section{Områdearealet}

Den totale reservoireffekttcethed er den totale energitæthed i reservoiret divideret med levetiden.

Den totale reservoireffekt er den totale reservoireffekttæthed multipliceret med områdearealet.

Transmissiviteten

Geotermivandsvolumenstrømmen er fundet som den optimale ud fra den økonomiske analyse.

Anloggsarealet er fundet som fire gange kvadratet på den beregnede værdi af boringsafstanden mellem injektions- og produktonsboringen.
Den geotermiske bruttoanlagseffekt er den geotermiske effekt, som brutto produceres ved en enkelt dublet.

Den geotermiske nettoanlagseffekt er den geotermiske bruttoanlægseffekt fratrukket den primære effekt til injektions- og produktionspumperne.

De geotermiske brutto- og nettoeffekttcetheder er de geotermiske brutto- og nettoanlægseffekter divideret med anlægsarealet.

Den geotermiske primare effektfaktor er forholdet mellem den geotermiske nettoanlægseffekt og den primære effekt tilført injektions- og produktionspumpen.

Bruttoanlagseffekten er den fjernvarmeeffekt, som brutto leveres fra et enkelt anlæg.

Nettoanlagseffekten er bruttoanlægseffekten fratrukket den samlede primære effekt tilført injektions- og produktionspumpen samt kompressorerne.

Brutto- og nettoeffekttcethederne er brutto og nettoanlægseffekterne divideret med anlægsarealet.

De totale brutto- og nettoeffekter er brutto- og nettoeffekttæthederne multipliceret med områdearealet.

Den totale primare effektfaktor er forholdet mellem nettoanlægseffekten og den samlede primære effekt tilført injektions- og produktionspumpen samt kompressorerne.

Den totale netto udnyttelsesfaktor er forholdet mellem nettoeffekttætheden og den totale reservoireffekttæthed. 
Tabel 1. Beregningsresultater for tilfaldet med høj transmissivitet og højt fjernvarmetemperaturniveau.

\begin{tabular}{|c|c|c|c|c|c|}
\hline Område & A & B & $\mathrm{Cl}$ & $\mathrm{C} 2$ & I alt \\
\hline Område areal $\left(\mathrm{km}^{2}\right)$ & 5200 & 3100 & 1700 & 9000 & 19000 \\
\hline Total reservoireffekt (GW) & 70,6 & 163,0 & 53,6 & 140,0 & 427,2 \\
\hline $\begin{array}{l}\text { Total reservoireffekttæthed } \\
\left(\mathrm{MW} / \mathrm{km}^{2}\right)\end{array}$ & 13,6 & 52,5 & 31,5 & 15,5 & 22,4 \\
\hline Tranmissivitet (Darcymeter) & 6,0 & 12,5 & 7,5 & 3,2 & 5,9 \\
\hline Geotermivandsvolumenstrøm $\left(\mathrm{m}^{3} / \mathrm{h}\right)$ & 263 & 362 & 279 & 128 & - \\
\hline Anlægsareal $\left(\mathrm{km}^{2}\right)$. & 5,47 & 1,95 & 2,49 & 2,07 & - \\
\hline Geotermisk bruttoanlægseffekt (MW) & 20,1 & 25,7 & 19,8 & 8,4 & - \\
\hline Geotermisk nettoanlægseffekt (MW) & 12,3 & 15,8 & 12,0 & 5,0 & - \\
\hline $\begin{array}{l}\text { Geotermisk bruttoeffekttæthed } \\
\left(\mathrm{MW} / \mathrm{km}^{2}\right)\end{array}$ & 3,67 & 13,20 & 7,97 & 4,06 & 5,79 \\
\hline $\begin{array}{l}\text { Geotermisk nettoeffekttæthed } \\
\left(\mathrm{MW} / \mathrm{km}^{2}\right)\end{array}$ & 2,25 & 8,09 & 4,85 & 2,42 & 3,52 \\
\hline Geotermisk primær effektfaktor (-) & 2,59 & 2,60 & 2,55 & 2,48 & 2,54 \\
\hline Bruttoanlægseffekt (MW) & 31,4 & 41,3 & 31,6 & 13,6 & - \\
\hline Nettoanlægseffekt (MW) & 10,6 & 13,6 & 10,3 & 4,1 & - \\
\hline Bruttoeffekttæthed $\left(\mathrm{MW} / \mathrm{km}^{2}\right)$ & 5,74 & 21,20 & 12,70 & 6,59 & 9,29 \\
\hline Nettoeffekttæthed $\left(\mathrm{MW} / \mathrm{km}^{2}\right)$ & 1,94 & 7,00 & 4,13 & 2,00 & 2,99 \\
\hline Total bruttoeffekt (GW) & 29,9 & 65,6 & 21,6 & 59,3 & 176,4 \\
\hline Total nettoeffekt (GW) & 10,1 & 21,7 & 7,0 & 18,0 & 56,8 \\
\hline Total primær effektfaktor (-) & 1,51 & 1,49 & 1,48 & 1,44 & 1,47 \\
\hline Total netto udnyttelsesfaktor $(-)$ & 0,143 & 0,133 & 0,131 & 0,129 & 0,133 \\
\hline
\end{tabular}


Tabel 2. Beregningsresultater for tilfalde med lav transmissivitet og højt fjernvarmetemperaturniveau.

\begin{tabular}{|c|c|c|c|c|c|}
\hline Område & A & $\mathrm{B}$ & $\mathrm{C} 1$ & $\mathrm{C} 2$ & I alt \\
\hline Områdeareal $\left(\mathrm{km}^{2}\right)$ & 5200 & 3100 & 1700 & 9000 & 19000 \\
\hline Total reservoireffekt (GW) & 70,6 & 163,0 & 53,6 & 140,0 & 427,2 \\
\hline $\begin{array}{l}\text { Total reservoireffekttæthed } \\
\left(\mathrm{MW} / \mathrm{km}^{2}\right)\end{array}$ & 13,6 & 52,5 & 31,5 & 15,5 & 22,4 \\
\hline Transmissivivitet (Darcymeter) & 1,20 & 3,75 & 2,25 & 1,20 & 1,71 \\
\hline Geotermivandsvolumenstrøm $\left(\mathrm{m}^{3} / \mathrm{h}\right)$ & 71 & 177 & 113 & 51 & - \\
\hline Anlægsareal $\left(\mathrm{km}^{2}\right)$ & 1,48 & 0,96 & 1,01 & 0,82 & - \\
\hline Geotermisk bruttoanlægseffekt (MW) & 5,4 & 12,6 & 8,0 & 3,4 & - \\
\hline Geotermisk nettoanlægseffekt (MW) & 3,3 & 7,6 & 4,8 & 2,0 & - \\
\hline $\begin{array}{l}\text { Geotermisk bruttoeffekttæthed } \\
\left(\mathrm{MW} / \mathrm{km}^{2}\right)\end{array}$ & 3,67 & 13,20 & 7,97 & 4,06 & 5,79 \\
\hline $\begin{array}{l}\text { Geotermisk nettoeffekttæthed } \\
\left(\mathrm{MW} / \mathrm{km}^{2}\right)\end{array}$ & 2,25 & 7,98 & 4,83 & 2,46 & 3,52 \\
\hline Geotermisk primær effektfaktor (-) & 2,58 & 2,54 & 2,54 & 2,53 & 2,55 \\
\hline Bruttoanlægseffekt (MW) & 8,4 & 20,0 & 12,7 & 5,4 & - \\
\hline Nettoanlægseffekt (MW) & 2,8 & 6,4 & 4,1 & 1,7 & - \\
\hline Bruttoeffekttæthed $\left(\mathrm{MW} / \mathrm{km}^{2}\right)$ & 5,71 & 21,00 & 12,70 & 6,59 & 9,25 \\
\hline Nettoeffekttæthed $\left(\mathrm{MW} / \mathrm{km}^{2}\right)$ & 1,89 & 6,72 & 4,04 & 2,03 & 2,94 \\
\hline Total bruttoeffekt (GW) & 29,7 & 65,0 & 21,5 & 59,3 & 175,5 \\
\hline Total nettoeffekt (GW) & 9,9 & 20,8 & 6,9 & 18,3 & 55,8 \\
\hline Total primær effektfaktor $(-)$ & 1,50 & 1,47 & 1,47 & 1,44 & 1,46 \\
\hline Total netto udnyttelsesfaktor (-) & 0,140 & 0,128 & 0,128 & 0,131 & 0,131 \\
\hline
\end{tabular}


Tabel 3. Beregningsresultatet for tilfaldet med høj transmissivitet og lavt fjernvarmetemperaturniveau.

\begin{tabular}{|c|c|c|c|c|c|}
\hline Område & A & $\mathrm{B}$ & $\mathrm{C} 1$ & $\mathrm{C} 2$ & I alt \\
\hline Områdeareal $\left(\mathrm{km}^{2}\right)$ & 5200 & 3100 & 1700 & 9000 & 19000 \\
\hline Total reservoireffket (GW) & 70,6 & 163,0 & 53,6 & 140,0 & 427,2 \\
\hline $\begin{array}{l}\text { Total reservoireffekttæthed } \\
\left(\mathrm{MW} / \mathrm{km}^{2}\right)\end{array}$ & 13,6 & 52,5 & 31,5 & 15,5 & 22,4 \\
\hline Transmissivitet (Darcymeter) & 6,0 & 12,5 & 7,5 & 3,2 & 5,9 \\
\hline Geotermivandsvolumenstrøm $\left(\mathrm{m}^{3} / \mathrm{h}\right)$ & 282 & 403 & 303 & 139 & - \\
\hline Anlægsareal $\left(\mathrm{km}^{2}\right)$. & 5,87 & 2,17 & 2,70 & 2,25 & - \\
\hline Geotermisk bruttoanlægseffekt (MW) & 21,4 & 28,5 & 21,4 & 9,1 & - \\
\hline Geotermisk nettoanlægseffekt (MW) & 12,7 & 16,6 & 12,5 & 5,2 & - \\
\hline $\begin{array}{l}\text { Geotermisk bruttoeffekttæthed } \\
\left(\mathrm{MW} / \mathrm{km}^{2}\right)\end{array}$ & 3,65 & 13,10 & 7,92 & 4,04 & 5,76 \\
\hline $\begin{array}{l}\text { Geotermisk nettoeffekttæthed } \\
\left(\mathrm{MW} / \mathrm{km}^{2}\right)\end{array}$ & 2,16 & 7,61 & 4,63 & 2,32 & 3,35 \\
\hline Geotermisk primær effektfaktor ( $(-)$ & 2,46 & 2,39 & 2,40 & 2,35 & 2,39 \\
\hline Bruttoanlægseffekt (MW) & 27,0 & 36,7 & 27,3 & 11,7 & - \\
\hline Nettoanlægseffekt (MW) & 13,1 & 17,2 & 12,8 & 5,3 & - \\
\hline Bruttoeffekttæthed $\left(\mathrm{MW} / \mathrm{km}^{2}\right)$ & 4,61 & 16,90 & 10,10 & 5,20 & 7,39 \\
\hline Nettoeffekttæthed $\left(\mathrm{MW} / \mathrm{km}^{2}\right)$ & 2,23 & 7,90 & 4,74 & 2,36 & 3,44 \\
\hline Total bruttoeffekt (GW) & 24,0 & 52,3 & 17,2 & 46,8 & 140,3 \\
\hline Total nettoeffekt (GW) & 11,6 & 24,5 & 8,1 & 21,3 & 65,5 \\
\hline Total primær effektfaktor (-) & 1,94 & 1,88 & 1,88 & 1,83 & 1,87 \\
\hline Total netto udnyttelsesfaktor (-) & 0,164 & 0,150 & 0,150 & 0,152 & 0,153 \\
\hline
\end{tabular}


Tabel 4. Beregningsresultater for tilfceldet med lav tranmissivitet og lavt fjernvarmetemperaturniveau.

\begin{tabular}{|c|c|c|c|c|c|}
\hline Område & A & $\mathrm{B}$ & $\mathrm{Cl}$ & $\mathrm{C} 2$ & I alt \\
\hline Områdeareal $\left(\mathrm{km}^{2}\right)$ & 5200 & 3100 & 1700 & 9000 & 19000 \\
\hline Total reservoireffekt (GW) & 70,6 & 163,0 & 53,6 & 140,0 & 427,2 \\
\hline $\begin{array}{l}\text { Total reservoireffekttæthed } \\
\left(\mathrm{MW} / \mathrm{km}^{2}\right)\end{array}$ & 13,6 & 52,5 & 31,5 & 15,5 & 22,4 \\
\hline Transmissivitet (Darcymeter) & 1,20 & 3,75 & 2,25 & 1,20 & 1,71 \\
\hline Geotermivandsvolumenstrøm $\left(\mathrm{m}^{3} / \mathrm{h}\right)$ & 80 & 194 & 125 & 61 & - \\
\hline Anlægsareal $\left(\mathrm{km}^{2}\right)$. & 1,66 & 1,05 & 1,11 & 0,99 & - \\
\hline Geotermisk bruttoanlægseffekt (MW) & 6,1 & 13,7 & 8,8 & 4,0 & - \\
\hline Geotermisk nettoanlægseffekt (MW) & 3,5 & 8,0 & 5,1 & 2,2 & - \\
\hline $\begin{array}{l}\text { Geotermisk bruttoeffekttæthed } \\
\left(\mathrm{MW} / \mathrm{km}^{2}\right)\end{array}$ & 3,65 & 13,10 & 7,92 & 4,04 & 5,76 \\
\hline $\begin{array}{l}\text { Geotermisk nettoeffekttæthed } \\
\left(\mathrm{MW} / \mathrm{km}^{2}\right)\end{array}$ & 2,12 & 7,61 & 4,59 & 2,27 & 3,31 \\
\hline Geotermisk primær effektfaktor $(-)$ & 2,39 & 2,39 & 2,38 & 2,29 & 2,34 \\
\hline Bruttoanlægseffekt (MW) & 7,6 & 17,3 & 11,1 & 5,1 & - \\
\hline Nettoanlægseffekt (MW) & 3,6 & 8,1 & 5,2 & 2,3 & - \\
\hline Bruttoeffekttæthed $\left(\mathrm{MW} / \mathrm{km}^{2}\right)$ & 4,57 & 16,50 & 9,99 & 5,16 & 7,28 \\
\hline Nettoeffekttæthed $\left(\mathrm{MW} / \mathrm{km}^{2}\right)$ & 2,15 & 7,70 & 4,62 & 2,28 & 3,34 \\
\hline Total bruttoeffekt (GW) & 23,7 & 51,3 & 17,0 & 46,5 & 138,5 \\
\hline Total nettoeffekt (GW) & 11,2 & 23,9 & 7,86 & 20,6 & 63,6 \\
\hline Total primær effektfaktor $(-)$ & 1,89 & 1,87 & 1,86 & 1,79 & 1,84 \\
\hline Total netto udnyttelsesfaktor $(-)$ & 0,159 & 0,147 & 0,147 & 0,147 & 0,149 \\
\hline
\end{tabular}




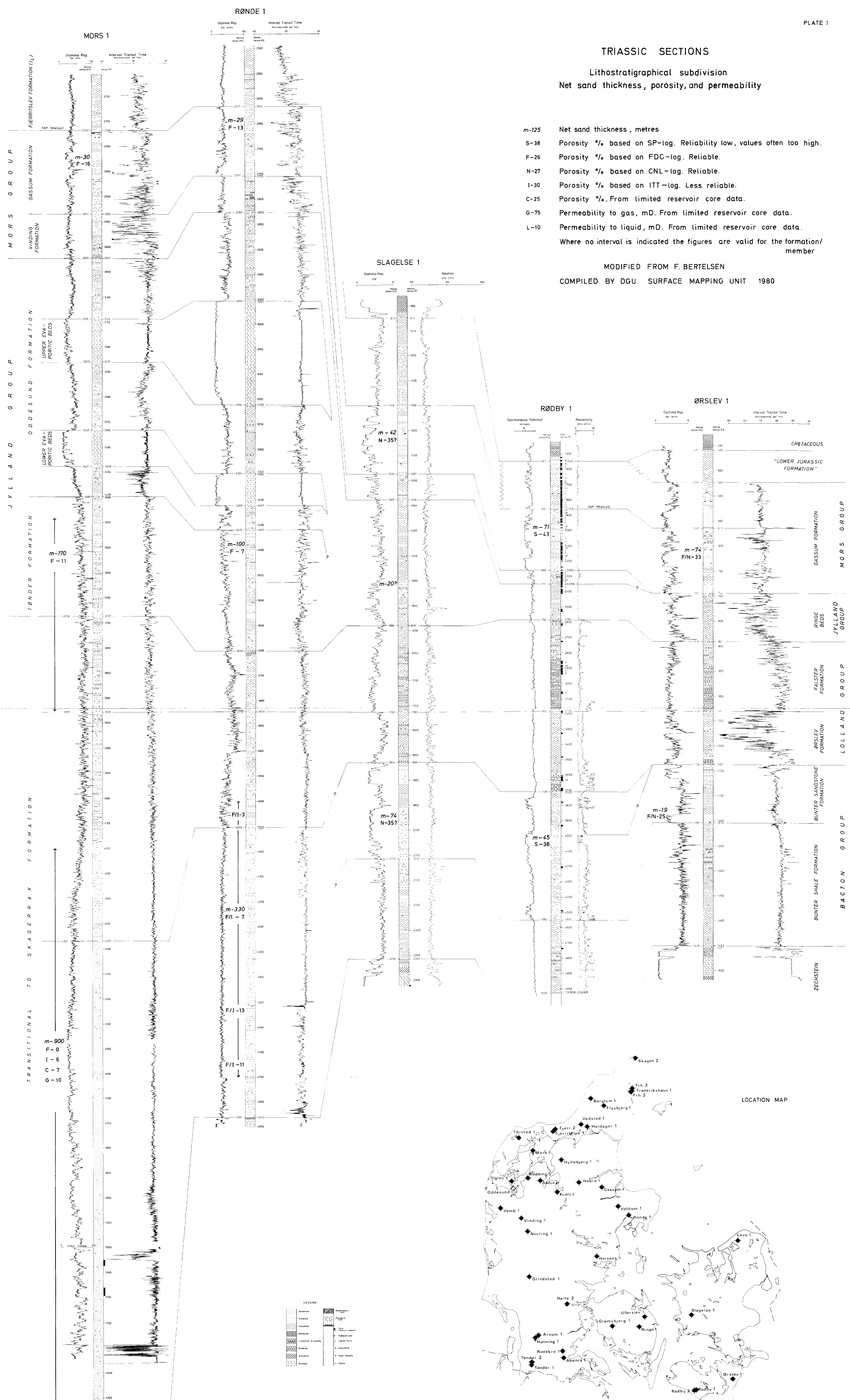




\section{TRIASSIC SECTIONS}

Lithostratigraphical subdivision

Net sand thickness, porosity, and permeability

of Gassum Formation

MODIFIED FROM

F. BERTELSEN 1976

D.G.U. 1980

VEMB 1

THISTED 1

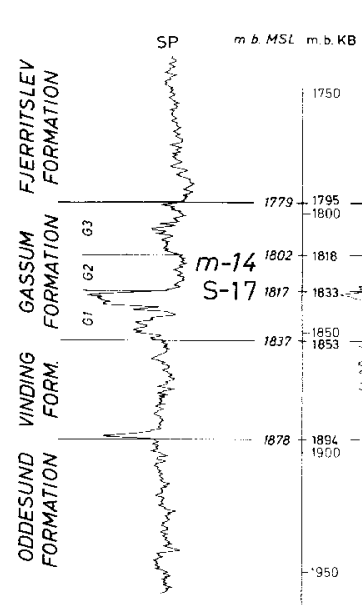

6 MSL

RES

\section{.}

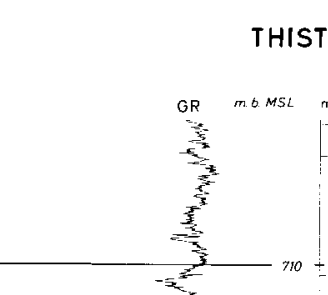

$m-39$
F-32

(166)

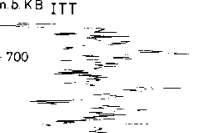

VEDSTED

PLATE 2

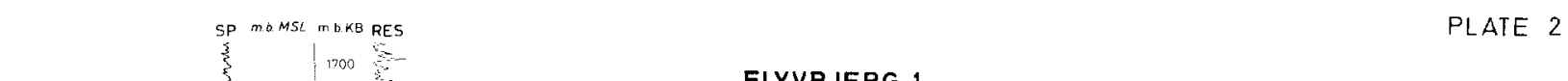

FLYVBJERG 1

FREDERIKSHAVN 2
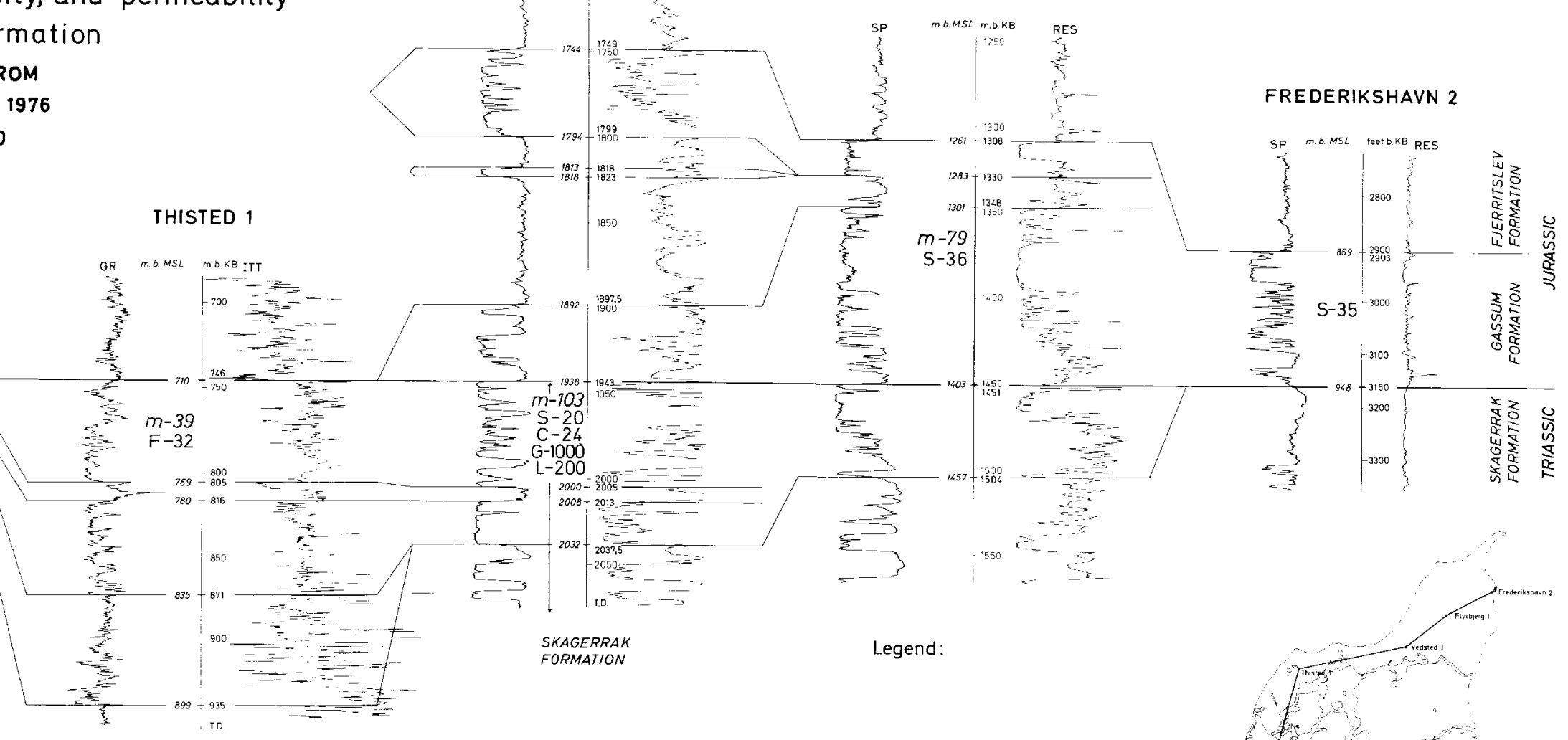

${ }^{2}=$

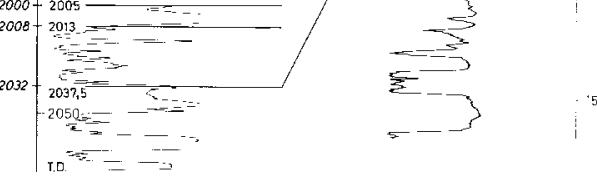

$=$

ODDESUND
FORMATION

Legend:

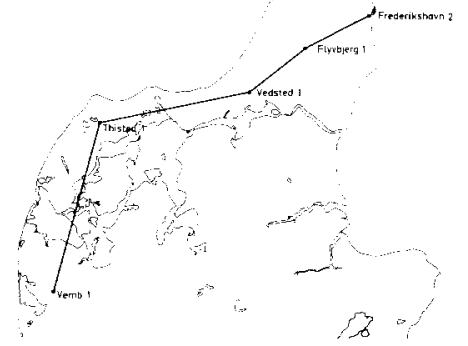




\section{TONDER 1}

HøNNING 1

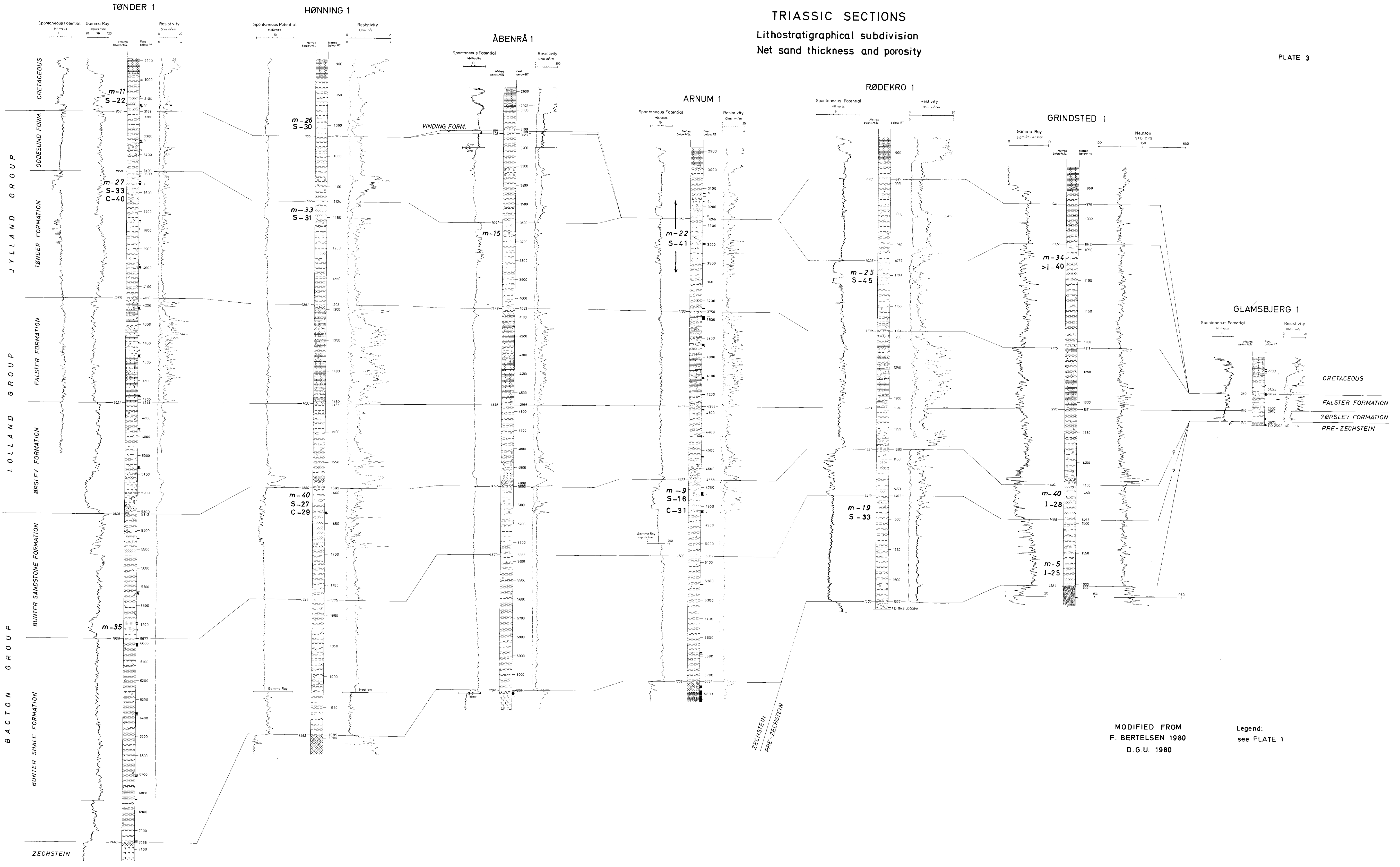


$G . R=$ gamma stråling

I.T.T = reciprok lydhastighed ( microsec. $/ \mathrm{ft}$ )

THISTED 1

MORS 1

HOBRO 1
PLATE 4

Legend:
see PLATE

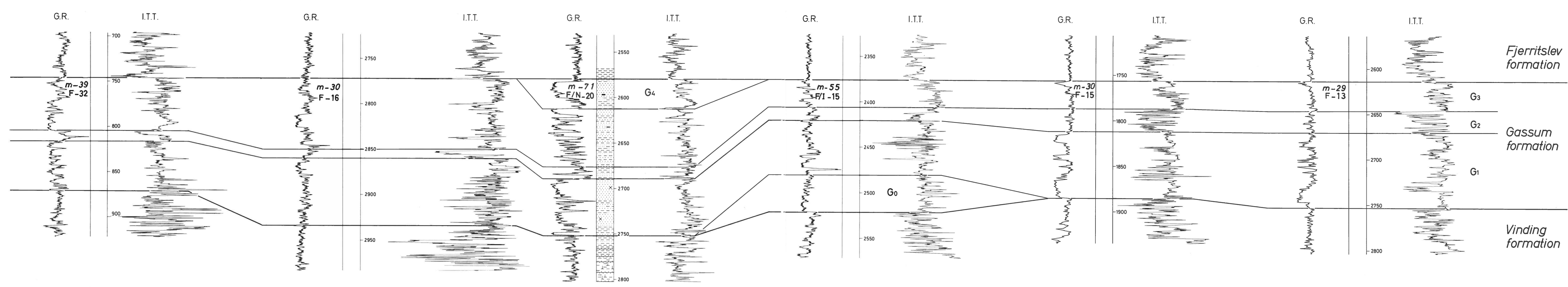




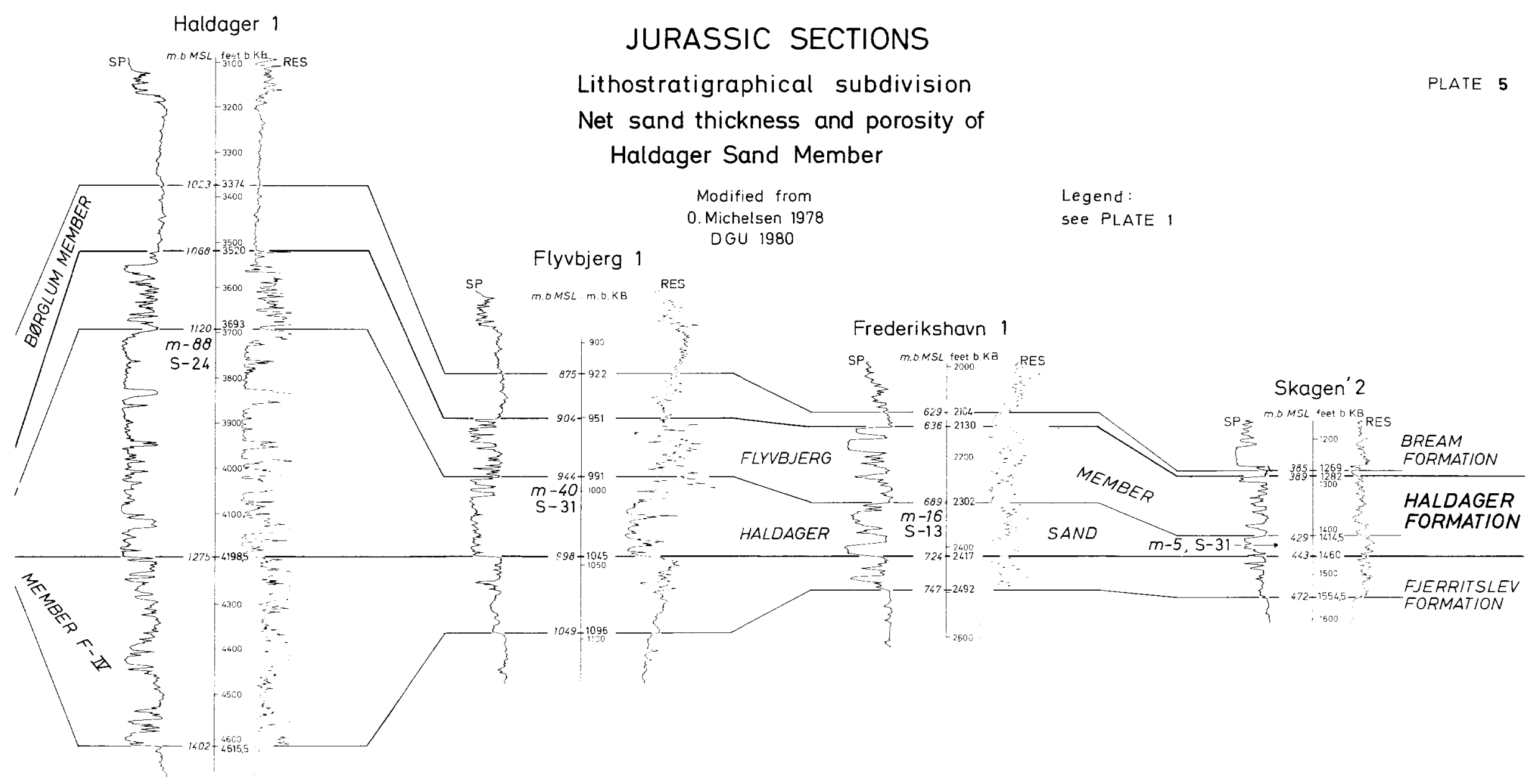


Legend:

see PLATE 1

\section{JURASSIC - LOWER CRETACEOUS SECTIONS}

Lithostratigraphical subdivision

Net sand thickness, porosity, and permeability

of Haldager Formation and Frederikshavn Member

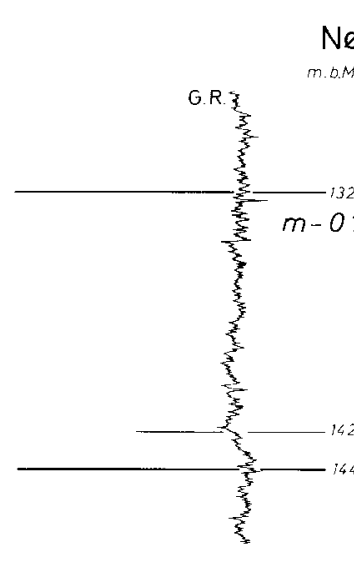

Novling 1

Modified from

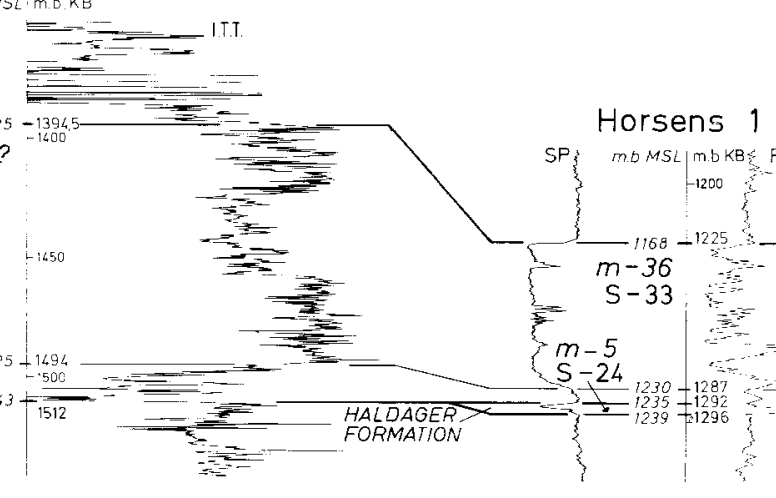

O. Michelsen 1978

DGU 1980
Rønde 1

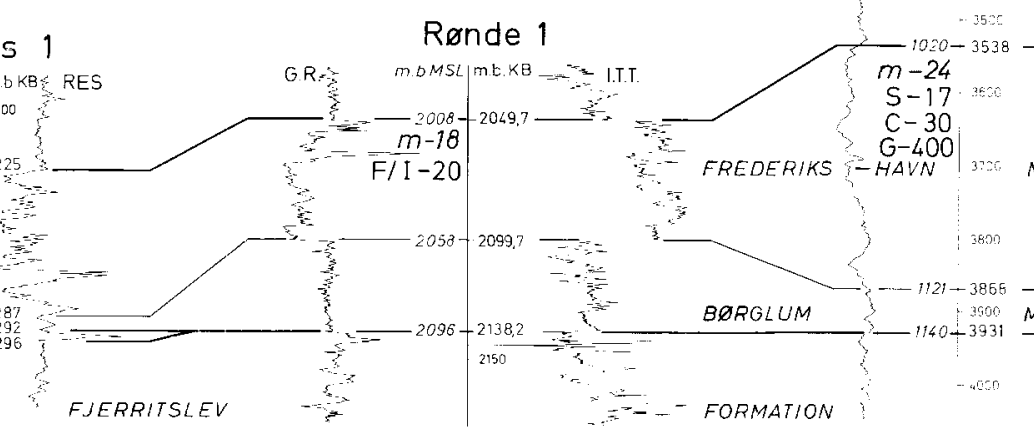

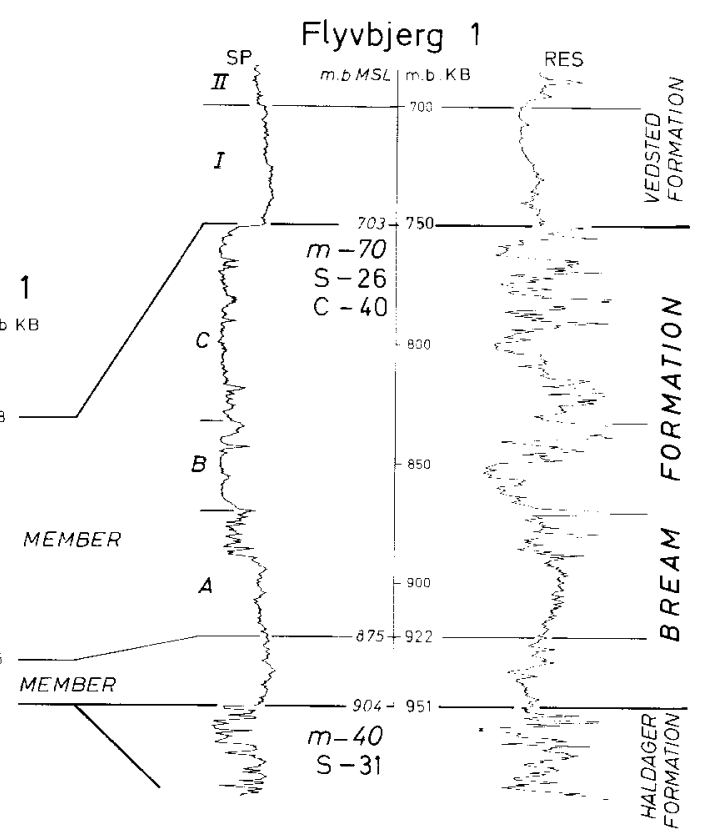




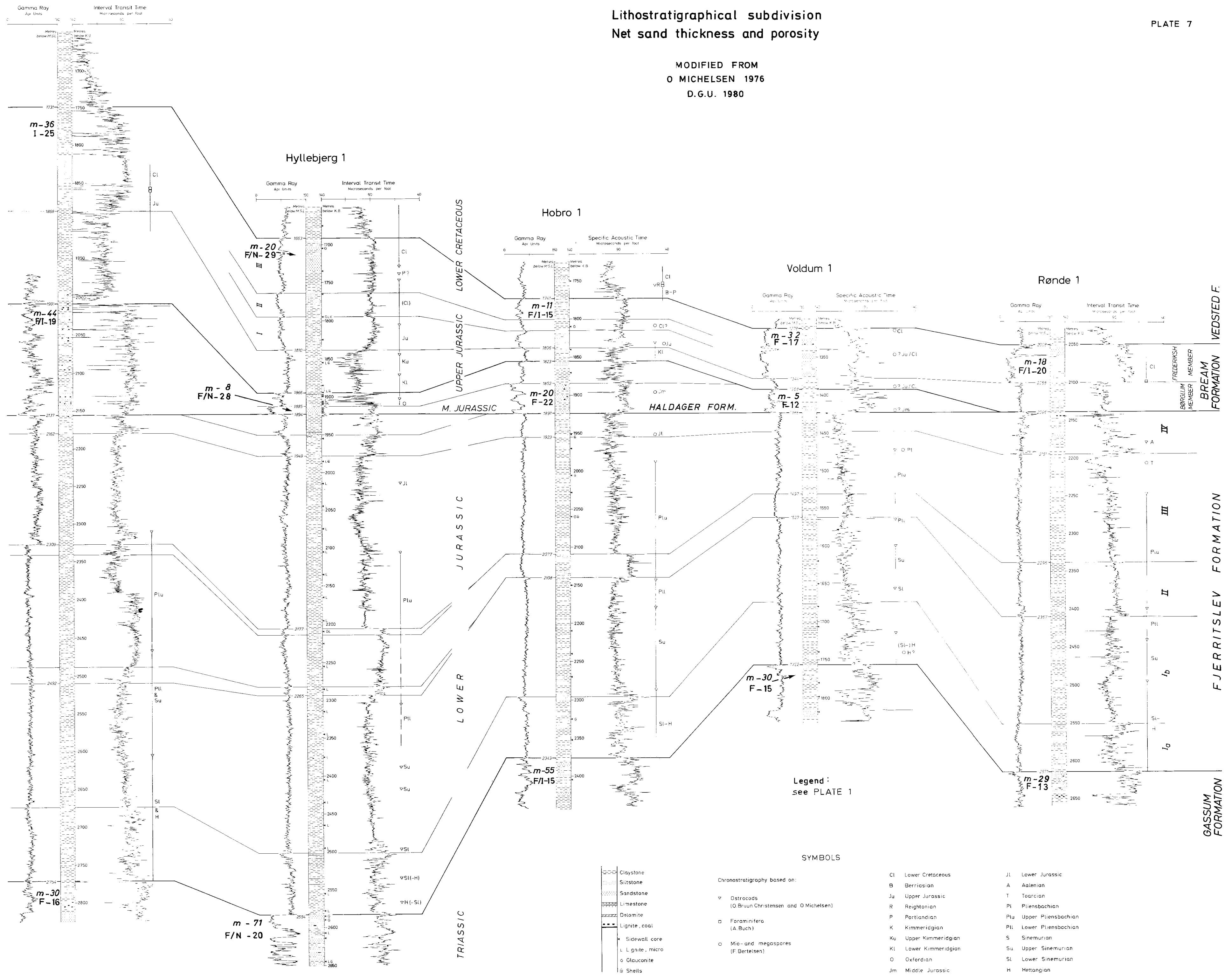




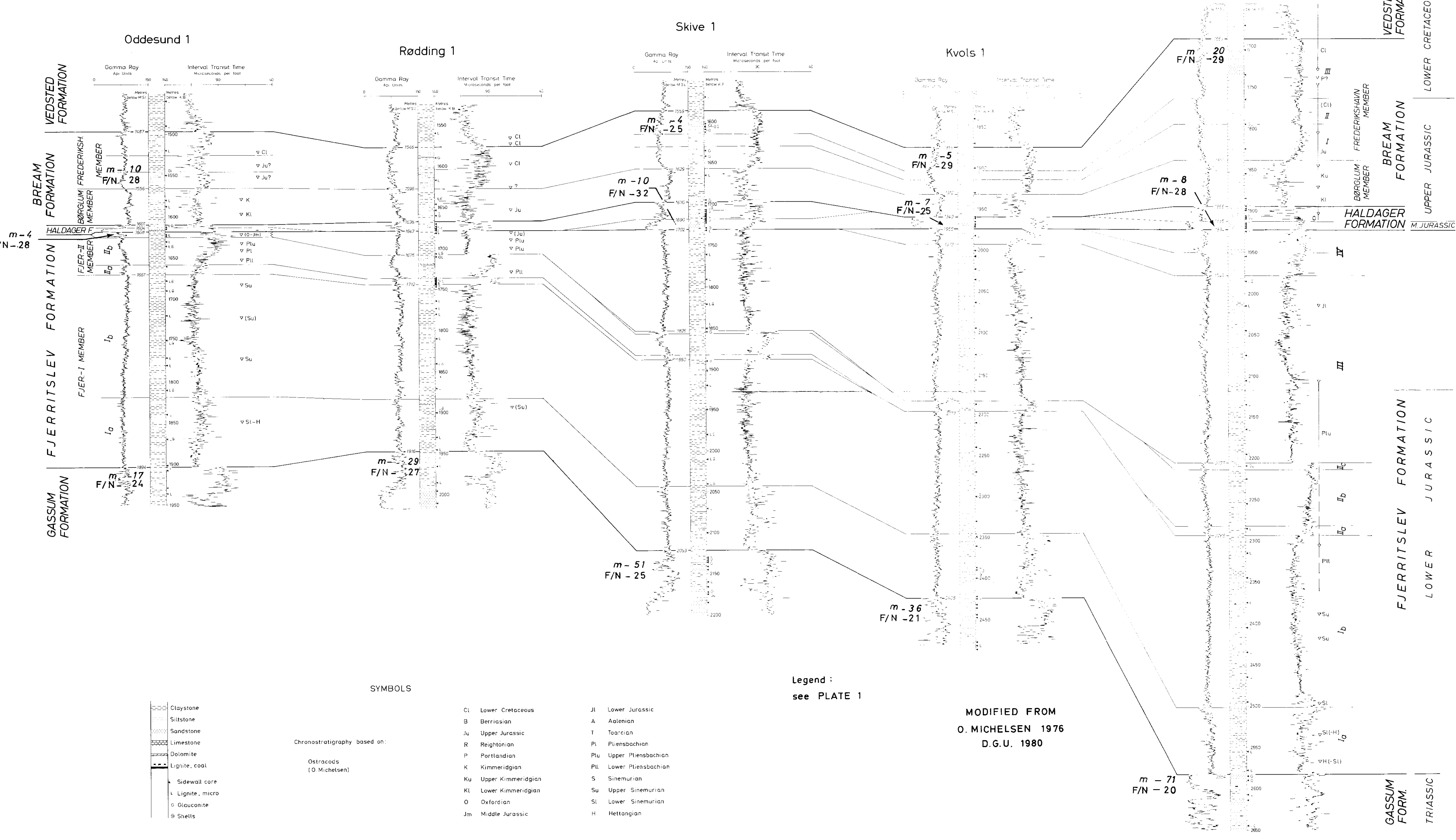


REFLECTION ISOCHRONE CONTOURS ON

TOP GASSUM FORMATION
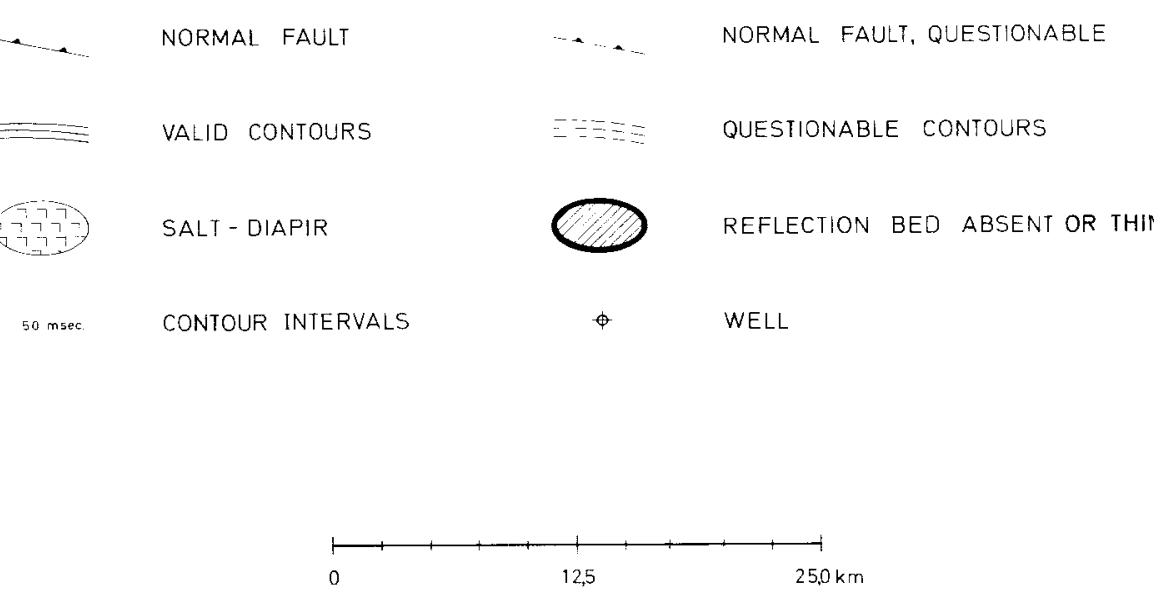

GEOLOGICAL SURVEY OF DENMARK

$1979-80$
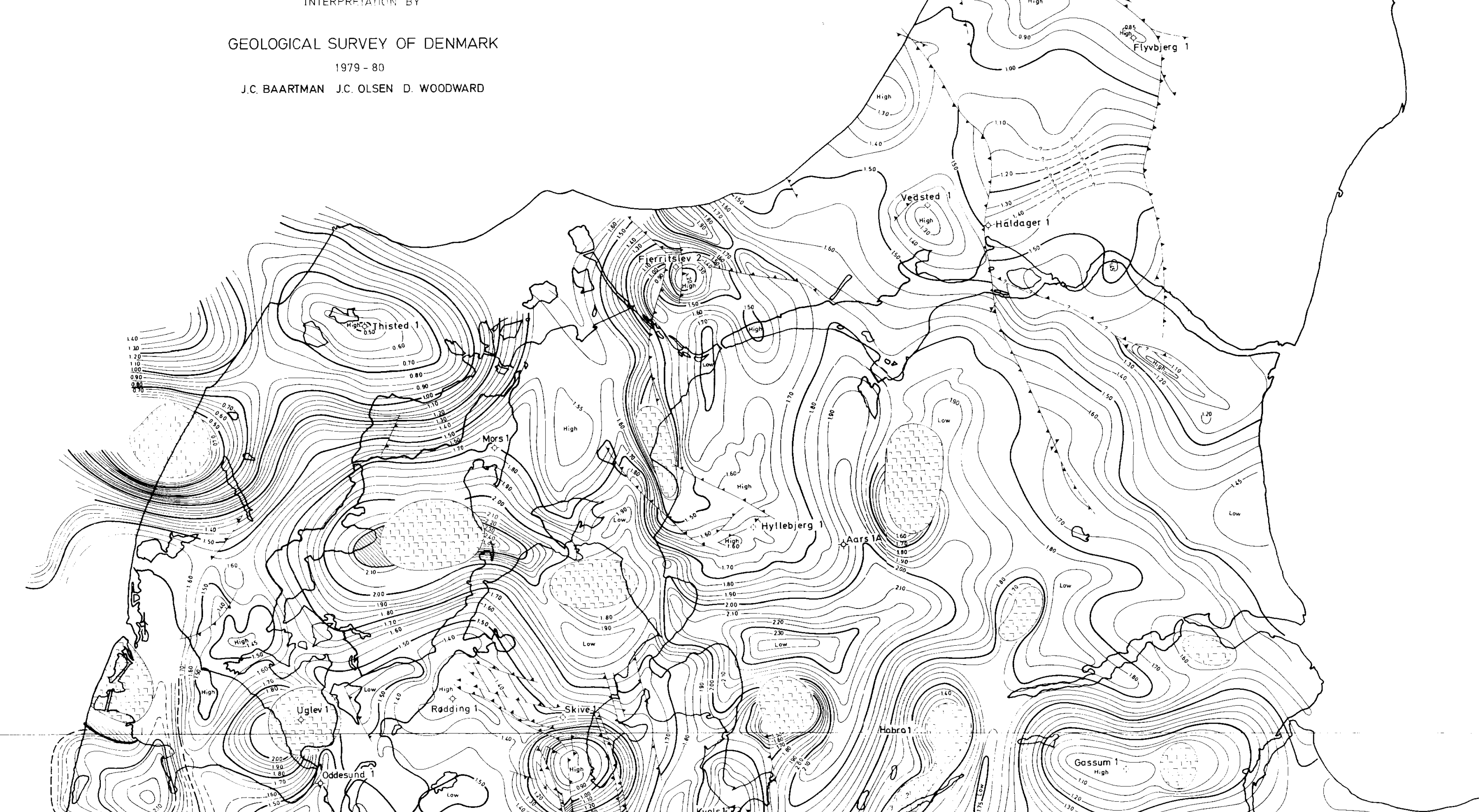

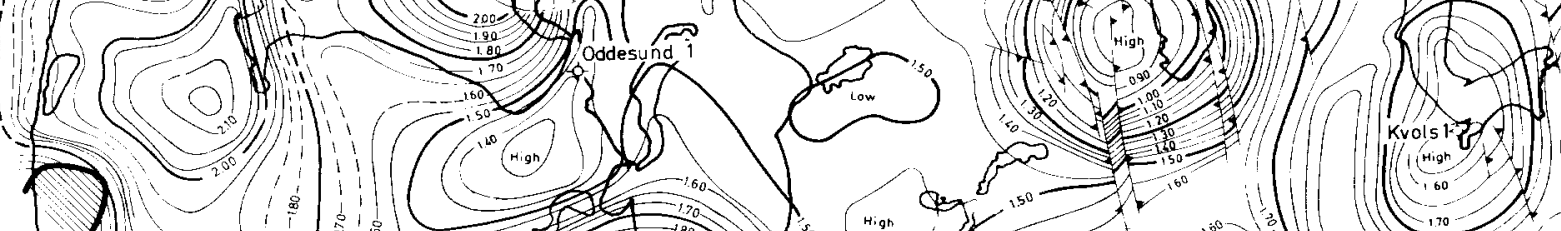

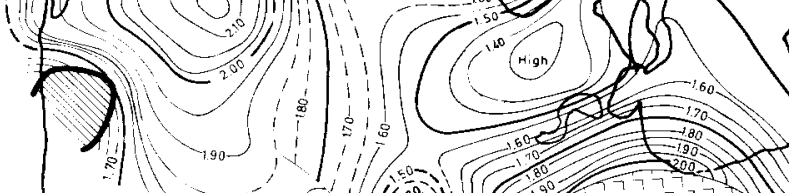

等,

8 (잉
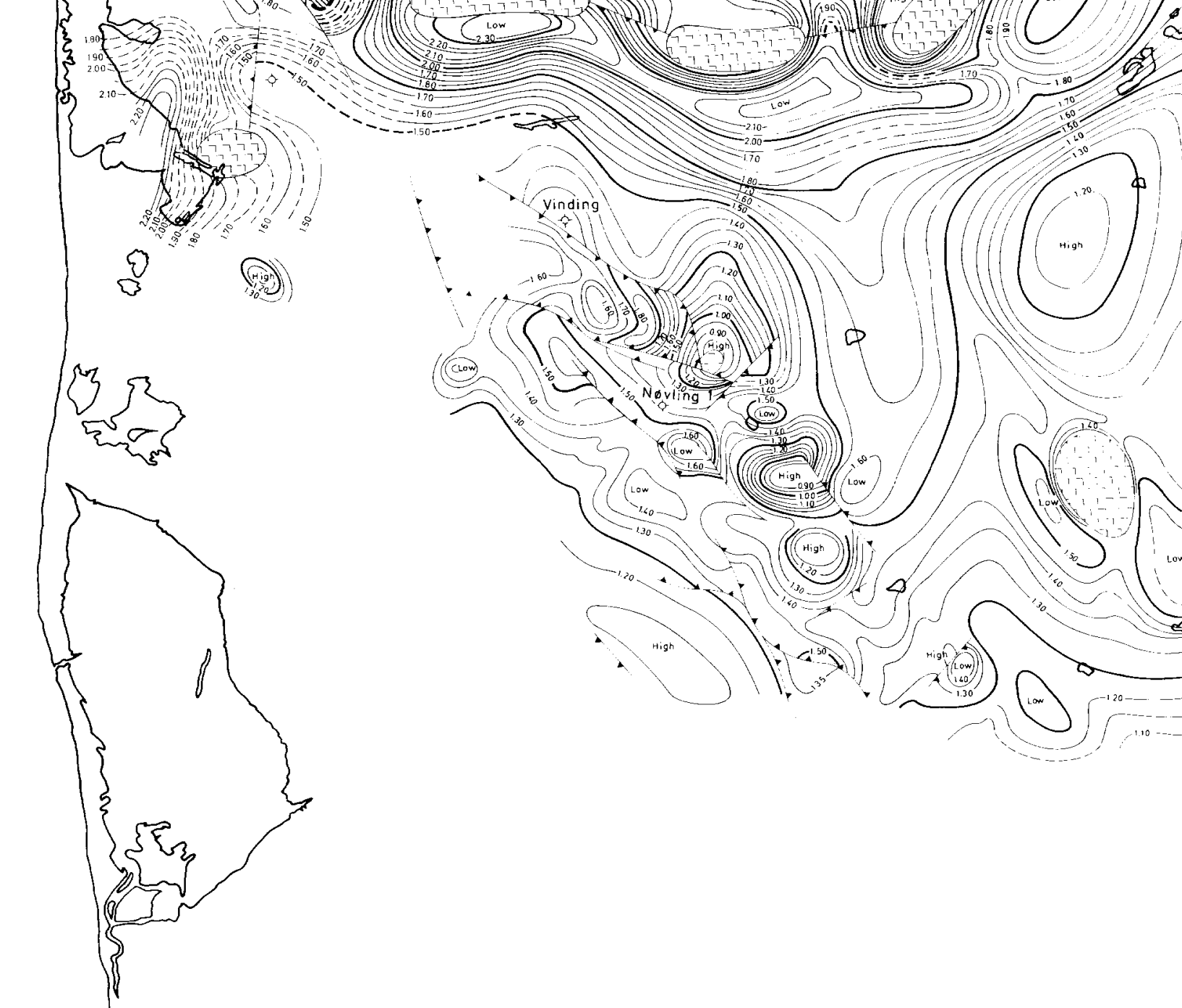

o
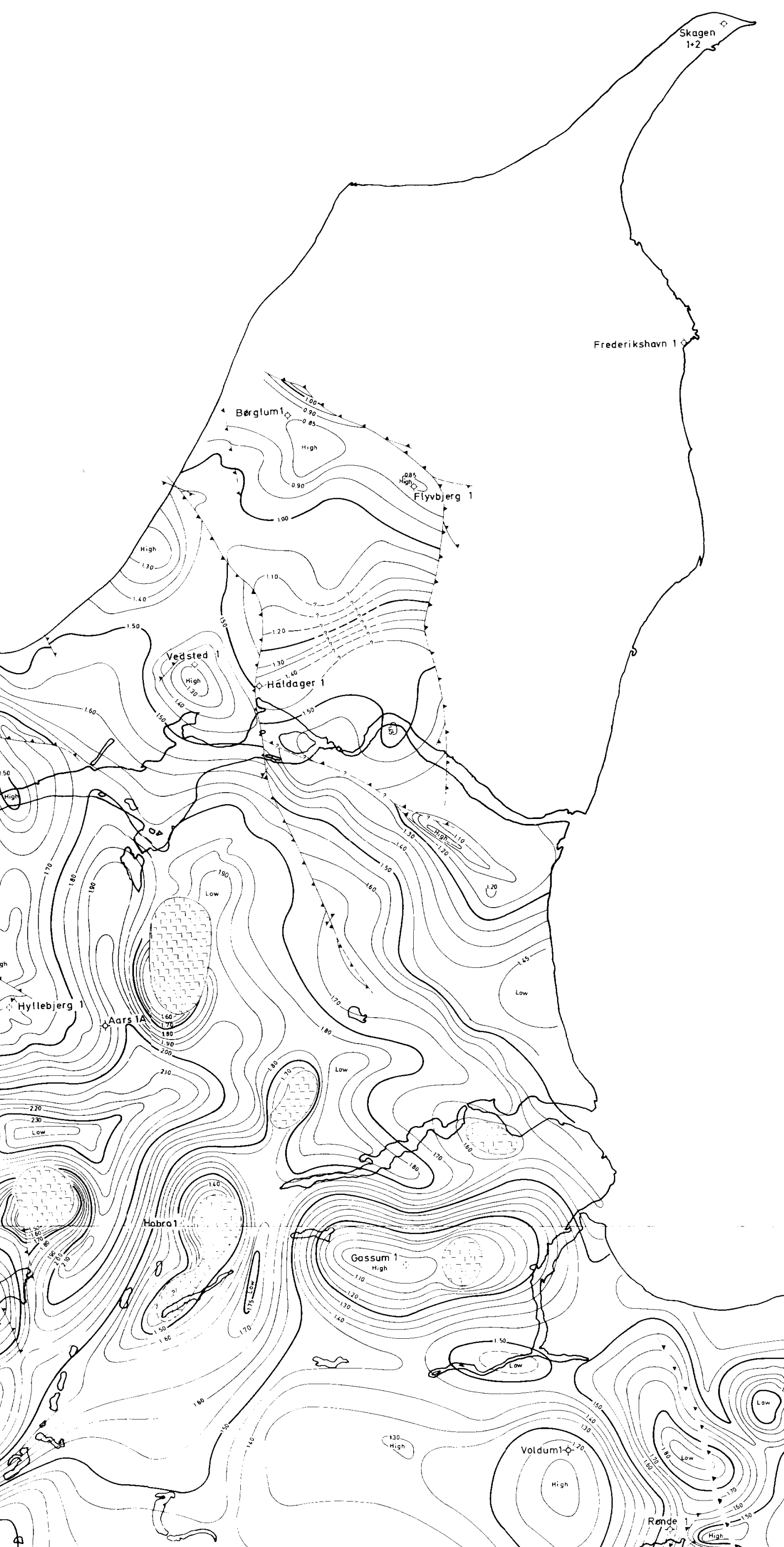


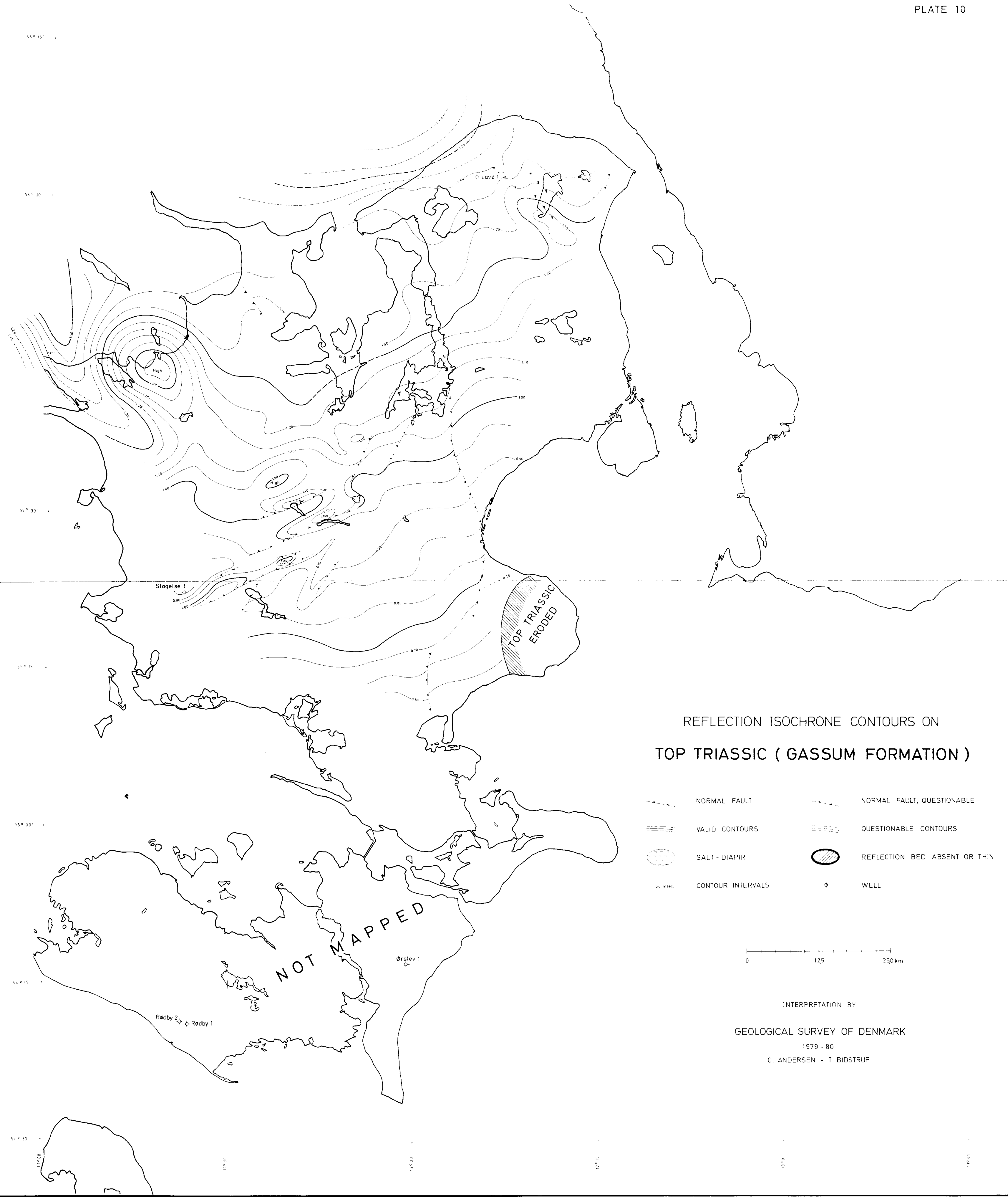

